Edinburgh Critical Studies in Renaissance Culture

\title{
THE GIRLHOOD \\ OF SHAKESPEARE'S \\ SISTERS
}

\author{
GENDER, \\ TRANSGRESSION, \\ ADOLESCENCE
}

\section{Jennifer Higginbotham}


The Girlhood of Shakespeare's Sisters 
Edinburgh Critical Studies in Renaissance Culture

Series Editor: Lorna Hutson

Titles available in the series:

Open Subjects: English Renaissance Republicans, Modern Selfhoods and the Virtue of Vulnerability

James Kuzner

$9780748642533 \mathrm{Hbk}$

The Phantom of Chance: From Fortune to Randomness in SeventeenthCentury French Literature

John D. Lyons

$9780748645152 \mathrm{Hbk}$

Don Quixote in the Archives: Madness and Literature in Early Modern Spain

Dale Shuger

$9780748644636 \mathrm{Hbk}$

Untutored Lines: The Making of the English Epyllion

William P. Weaver

$9780748644650 \mathrm{Hbk}$

Friendship's Shadows: Women's Friendship and the Politics of Betrayal in England, 1640-1705

Penelope Anderson

$9780748655823 \mathrm{Hbk}$

The Girlhood of Shakespeare's Sisters: Gender, Transgression, Adolescence

Jennifer Higginbotham

$9780748655908 \mathrm{Hbk}$

Inventions of the Skin: The Painted Body in Early English Drama Andrea Stevens

$9780748670499 \mathrm{Hbk}$

Visit the Edinburgh Critical Studies in Renaissance Culture website at www.euppublishing.com/series/ecsrc 


\section{The Girlhood of Shakespeare's Sisters}

Gender, Transgression, Adolescence

Jennifer Higginbotham 
(C) Jennifer Higginbotham, 2013

Edinburgh University Press Ltd

22 George Square, Edinburgh EH8 9LF

www.euppublishing.com

Typeset in 10.5/13 Adobe Sabon

by Servis Filmsetting Ltd, Stockport, Cheshire, and printed and bound in Great Britain by

CPI Group (UK) Ltd, Croydon CR0 4YY

A CIP record for this book is available from the British Library

ISBN 9780748655908 (hardback)

ISBN 9780748655915 (webready PDF)

ISBN 9780748655939 (epub)

ISBN 9780748655922 (Amazon ebook)

The right of Jennifer Higginbotham

to be identified as author of this work

has been asserted in accordance with

the Copyright, Designs and Patents Act 1988. 


\section{Contents}

Acknowledgments vi

Series Editor's Preface viii

Introduction 1

1 'A wentche, a gyrle, a Damsell': Defining Early Modern Girlhood 20

2 Roaring Girls and Unruly Women: Producing Femininities 62

3 Female Infants and the Engendering of Humanity 104

4 Where Are the Girls in English Renaissance Drama? 144

5 Voicing Girlhood: Women's Life Writing and Narratives of Childhood 179

Epilogue: Mass-Produced Languages and the End of Touristic Choices

Bibliography 204

$\begin{array}{ll}\text { Index } & 220\end{array}$ 


\section{Acknowledgements}

This book owes a tremendous debt to the friends and colleagues who have supported me over the past ten years. My work on girlhood began with a question in Phyllis Rackin's Shakespeare seminar at the University of Pennsylvania, and if it weren't for her unfailing support as a mentor and advisor, this project never would have come to fruition. It is also better and stronger for the feedback I received from Peter Stallybrass and Rebecca Bushnell, who have always been incredibly generous with their comments and time. As the project has developed, I have been fortunate to have the advice of my fellow scholars at The Ohio State University, especially Alan Farmer, Chris Highley, Richard Dutton, Luke Wilson, Hannibal Hamlin and John King, and I am grateful to Lorna Hutson as the series editor for seeing the project to its completion.

Over the years the 'noble girls' from my writing groups have provided a wonderful support system, and I want to thank Elizabeth Williamson, Jane Dagenhardt, Jessica Rosenfeld, Jamie Taylor and Marissa Greenberg for reading through so many of my early drafts. I am also deeply indebted to the work of Will Fisher, whose work on boyhood served as a lightning rod for my project, and to Kate Chedgzoy, whose suggestions for research helped open new avenues of exploration and enabled me to write the book I wanted to write. A number of other scholars have also offered wonderful recommendations over the years, including Erika Lin, Melissa Sanchez, Claire Busse, Gina Bloom, Laura Gowing, Gordon McMullan, Lucy Munroe, Ann Thompson, Diane Purkiss, Caroline Bicks, Deanne Williams, Margreta de Grazia, David Wallace, Rita Copeland, Vicki Mahaffey and Emily Steiner. Stephanie Gibbs Kamath deserves a medal for listening to me wax enthusiastic about dictionary entries over endless cups of tea in the British Library, and Justine Murison, Alex Fleck and Veronica Schanoes will always have my undying gratitude for all the hours they spent listening to me talk about girlhood. My thanks also go to Jared Ellman for his many 
kindnesses, and to Karen Robertson and Leslie Dunn, for introducing me to feminist Renaissance studies. Last but not least, Robert Sherwood has my love and my promise that the next book won't involve nearly so many 'Girl Power' jokes.

Parts of the Introduction and a version of Chapter 1 were previously published as 'Fair Maids and Golden Girls: The Vocabulary of Female Youth in Early Modern English', Modern Philology 110 (2011), pp. 171-96, () 2011 by The University of Chicago. All rights reserved. 


\section{Series Editor's Preface}

Edinburgh Critical Studies in Renaissance Culture may, as a series title, provoke some surprise. On the one hand, the choice of the word 'culture' (rather than, say, 'literature') suggests that writers in this series subscribe to the now widespread assumption that the 'literary' is not isolable, as a mode of signifying, from other signifying practices that make up what we call 'culture'. On the other hand, most of the critical work in English literary studies of the period 1500-1700 which endorses this idea has rejected the older identification of the period as 'the Renaissance', with its implicit homage to the myth of essential and universal Man coming to stand (in all his sovereign individuality) at the centre of a new world picture. In other words, the term 'culture' in the place of 'literature' leads us to expect the words 'early modern' in the place of 'Renaissance'. Why, then, 'Edinburgh Critical Studies in Renaissance Culture'?

The answer to that question lies at the heart of what distinguishes this critical series and defines its parameters. As Terence Cave has argued, the term 'early modern', though admirably egalitarian in conception, has had the unfortunate effect of essentialising the modern, that is, of positing 'the advent of a once-and-for-all modernity' which is the deictic 'here and now' from which we look back. ${ }^{1}$ The phrase 'early modern', that is to say, forecloses the possibility of other modernities, other futures that might have arisen, narrowing the scope of what we may learn from the past by construing it as a narrative leading inevitably to Western modernity, to 'us'. Edinburgh Critical Studies in Renaissance Culture aims rather to shift the emphasis from a story of progress - early modern to modern - to series of critical encounters and conversations with the past, which may reveal to us some surprising alternatives buried within texts familiarly construed as episodes on the way to certain identifying features of our endlessly fascinating modernity. In keeping with one aspect of the etymology of 'Renaissance' or 'Rinascimento' as 'rebirth', moreover, this series features books that explore and interpret 
anew elements of the critical encounter between writers of the period 1500-1700 and texts of Greco-Roman literature, rhetoric, politics, law, oeconomics, eros and friendship.

The term 'culture', then, indicates a licence to study and scrutinise objects other than literary ones, and to be more inclusive about both the forms and the material and political stakes of making meaning both in the past and in the present. 'Culture' permits a realisation of the benefits to be reaped after two decades of interdisciplinary enrichment in the arts. No longer are historians naïve about textual criticism, about rhetoric, literary theory or about readerships; likewise, literary critics trained in close reading now also turn easily to court archives, to legal texts, and to the historians' debates about the languages of political and religious thought. Social historians look at printed pamphlets with an eye for narrative structure; literary critics look at court records with awareness of the problems of authority, mediation and institutional procedure. Within these developments, modes of research that became unfashionable and discredited in the 1980s - for example, studies in classical or vernacular 'source texts', or studies of literary 'influence' across linguistic, confessional and geographical boundaries - have acquired a new critical edge and relevance as the convergence of the disciplines enables the unfolding of new cultural histories (that is to say, what was once studied merely as 'literary influence' may now be studied as a fraught cultural encounter). The term 'Renaissance' thus retains the relevance of the idea of consciousness and critique within these textual engagements of past and present, and, while it foregrounds the Western European experience, is intended to provoke comparativist study of wider global perspectives rather than to promote the 'universality' of a local, if far-reaching, historical phenomenon. Finally, as traditional pedagogic boundaries between 'Medieval' and 'Renaissance' are being called into question by cross-disciplinary work emphasising the 'reformation' of social and cultural forms, so this series, while foregrounding the encounter with the classical past, is self-conscious about the ways in which that past is assimilated to the projects of Reformation and Counter-Reformation, spiritual, political and domestic, that finally transformed Christendom into Europe.

Individual books in this series vary in methodology and approach, sometimes blending the sensitivity of close literary analysis with incisive, informed and urgent theoretical argument, at other times offering critiques of grand narratives of the period by their work in manuscript transmission, or in the archives of legal, social and architectural history, or by social histories of gender and childhood. What all these books have in common, however, is the capacity to offer compelling, well-documented 
x The Girlhood of Shakespeare's Sisters

and lucidly written critical accounts of how writers and thinkers in the period 1500-1700 reshaped, transformed and critiqued the texts and practices of their world, prompting new perspectives on what we think we have learned from them.

Lorna Hutson

\section{Note}

1. Terence Cave, 'Locating the Early Modern', Paragraph 29:1 (2006), pp. 12-26, p. 14. 


\section{Introduction}

What does 'feminist' mean? Feminist is formed with the word 'femme,' 'woman,' and means: someone who fights for women. For many of us it means someone who fights for women as a class and for the disappearance of this class.

Monique Wittig ${ }^{1}$

Woman herself is never at issue in these statements: the feminine is defined as the necessary complement to the operation of male sexuality, and, more often, as a negative image that provides male sexuality with an unfailingly phallic self-representation.

Luce Irigaray $^{2}$

This book takes as its point of departure the striking absence of girlhood in recent studies of early modern literature and drama, an absence that is particularly noteworthy in view of the considerable attention this scholarship has paid to boys. Although female children occupied a crucial and contested position in the early modern sex-gender system, our critical frameworks have not known how to account for them. We have been reading past their distinct positions as 'girls', 'maids', 'damsels' and 'wenches' by subsuming all female characters into the category of 'women'. The result has been that feminist literary criticism has been without a critical vocabulary to counteract what Luce Irigaray calls 'sexual (in)difference', whereby female identities exist only as mirrors for men. Discourses of girlhood, I argue, fragmented gender categories in early modern England, producing multiple categories of femininity and femaleness; if the category of 'women' in early modern England was at times figured as merely a reflection of 'men', it was at best a fractured mirror.

Although it may seem strange to couple Wittig's socialist theory with Irigaray's psychoanalytical perspective in my epigraphs, I would suggest that where they come together is in their insistence that 'woman' and 
'women' are multiple - 'not one', to use Irigaray's formulation. Rather than being part of a single girl/woman binary, 'girl' was one of many terms for young female human beings in early modern English. The process of inculcating femininity and 'making' women was neither uniform across class nor did it happen without resistance. Along the way it also produced (among other positions) 'girls', 'maids', 'damsels', 'wenches' and 'whores'. What looking at girls and girlhood has made clear to me is that 'women' and 'femininity' were not stable, easily defined categories and that, in fact, definitions of femininity were very much fragmented by age, class and context. As such, it seems time to rethink the two dominant scholarly models for conceptualising early modern gender and social hierarchies: (1) the triangular relationship between men, women and boys emphasised in recent scholarly explorations of early modern sexuality and sexual difference and (2) the division of the female life cycle into the categories 'maid', 'wife' and 'widow'. Both of these triads had significant cultural currency in the sixteenth and seventeenth centuries, but the category of the 'girl' exposes their limitations. When we ignore girls, and, indeed, when we ignore female human beings who do not fit into the category of 'woman', we unwittingly buy into the patriarchal narrative that depends upon collapsing differences between female identities in order to define male identities against them.

The category of the 'girl', on the other hand, disrupts the reified female identity categories on which both models were based and that contemporary literary criticism has unwittingly reproduced. In 1989, Stephen Orgel voiced a question that would preoccupy scholars of Renaissance literature for more than two decades: 'Why Did the English Stage Take Boys for Women?'3 Orgel was one of several forward-looking scholars in the late 1980s who recognised the importance of Shakespeare's transvestite theatre to the interpretation of his plays. His simply put question - he called it 'crude' - led to anything but simple answers, and even after more than twenty years, no consensus has been reached. For Orgel, the 'real question' was how early modern culture constructed sex and gender, an issue that he tackled in even more depth in his subsequent monograph, Impersonations. ${ }^{4}$ Like most exciting scholarly issues, Orgel's question required historical and cultural interpretation rather than bare facts, and it opened up conversations between competing schools of thought. ${ }^{5}$ The terms of that conversation, however, limited the kind of inquiries that could be made. One reason female children have been marginalised in literary criticism is that the term 'girl' has been missing from our analytical vocabularies. Behind Orgel's question lie several others: if the English stage took boys for women, where did 
the girls fit in? Did the English stage take boys for girls, and what difference did that make? And how did the gendering of girls take place in early modern culture more generally?

I have chosen to focus on Orgel's work not to scapegoat him, but because his question so clearly illustrates the critical blind spot that the overwhelming emphasis on boys and women has produced in early modern studies. I also want to suggest that his work offers a way to think past that blind spot. Orgel's feminist analysis has laid the groundwork necessary to begin answering these questions. He has convincingly argued that unlike our modern male/female binary that pits men against women, the early modern sex-gender system was organised around a tripartite distinction that defined mature men against women and boys. As Rosalind in William Shakespeare's As You Like It suggests, both boys and women were feminised in the early modern imagination. Claiming to have cured a lovesick youth by posing as his mistress, Rosalind tells Orlando:

He was to imagine me his love, his mistress; and I set him every day to woo me. At which time would I, being but a moonish youth, grieve, be effeminate, changeable, longing and liking, proud, fantastical, apish, shallow, inconstant, full of tears, full of smiles, for every passion something and for no passion truly anything, as boys and women are for the most part cattle of this colour. $(3.2 .395-403)^{6}$

As a boy playing a female character playing a boy, Rosalind both enacts and articulates the connection between boys and women on the early modern stage and in early modern culture. Men occupied the highest tier in the overall social hierarchy, and boys and women occupied similar subject positions below. They were both, as Rosalind says, objects of exchange and erotic attraction for adults. This model of gender construction hierarchised adult men's masculinity over the femininity and effeminacy of the other two categories.

The tripartite model has a powerful explanatory force for drama, but the danger of stopping with this comparison between boys and women - and the danger of stopping with the tripartite distinction in general - is that the category 'women' appears stable, fixed and natural compared to the developmental trajectory between 'boys' and 'men'. That is to say, it doesn't account for Simone de Beauvoir's observation that one is not born, but rather becomes a woman. As Beauvoir points out, female human beings are shaped as 'women' in a lived encounter with a patriarchal world. Her central insight, in Toril Moi's words, is that 'the fact of being born with a female body starts a process which will have specific, yet unforeseeable consequences ... To Beauvoir the relationship 
between one's body and one's subjectivity is neither necessary nor arbitrary but contingent. ${ }^{7}$ This contingent interplay between an individual woman's experiences and gender norms could not be accommodated in the tripartite model, which depended upon marking 'women' as 'women' to stabilise gender categories within a system of social control. It could not articulate the ways a boy playing a young female character would have been gendered differently from a boy playing an adult woman.

I do not want to fall into the trap against which Toril Moi rightly cautions of assuming that we can never use the words 'women' or 'girls' without quotation marks, or of confusing constructivism with liberation. To avoid this, Moi suggests turning to Beauvoir, whose philosophy was neither radically constructivist nor, conversely, essentialist in the usual sense; Beauvoir saw the possession of a female body as what laid the groundwork for being made into a 'woman', but she did not see the female body as carrying any 'necessary social and political consequences'. ${ }^{8}$ If Beauvoir believed in biology, she did not believe biology was destiny. However, having a female body does not necessarily make one a 'woman'. As Wittig importantly points out, the category 'women' has historically and in certain contexts excluded a range of people because of race, class, age and sexual orientation, ${ }^{9}$ and recent attention to transgender identities has made it clear that what constitutes a female body can be just as controversial as what constitutes the social category of 'women'. ${ }^{10}$ If Beauvoir was willing to include anyone with a female body, early modern society was not.

One way to start dismantling the universalising and often exclusionary uses of 'woman' as a conceptual category is to look at the other feminine identities in relation to which it has been defined. What began as a question of location in this project (where were the girls in early modern literature, and how did they fit into the sex-gender system?) quickly became a question of meaning: what was an early modern girl, or at least what did I mean by 'girl' when I asked that question? Whether or not we see girls as absent or present depends very much upon how we define them, and the question becomes no easier if we substitute the phrase 'female children', since the definition of 'child' was no more stable in this period than 'woman' or 'girl'. The heavy reliance on canonical drama has also compounded the absence of female children in our critical discussions because there is a general perception that girl characters, unlike boys, were scarce. Of the roughly forty-five children in Mark Lawhorn's annotated checklist of children in Shakespeare's plays, only four are girls, and the appearance of Clarence's daughter in Richard III has been deemed unusual by the few critics who mention her. ${ }^{11}$ Yet 
the use of female infants on stage was not unknown (my appendix to Chapter 3 includes seven in addition to the three well-known examples of Perdita, Marina and Elizabeth I in Shakespeare's plays), nor were teenage daughters scarce. The female child we think is missing from early modern drama is a particular type of female child: the modern, pre-adolescent girl who functions predominantly as a child. She walks and talks, receives an education and participates in social relations, but her role is not predominantly sexual or romantic. By and large, the most well-known examples of young female characters on the public stage do not correspond to our notion of what counts as a 'girl'; instead, the most frequently discussed stage narratives focus on young women's entrance into the heterosexual marriage market, in part because of the generic demands of romantic comedy.

My approach to this problem at first was to expand my notion of who counted as a girl, a methodological approach that I found enormously generative. Juliet, for example, certainly gets called a 'girl', as do Katherina in Taming of the Shrew, Jessica in Merchant of Venice, Rosalind in As You Like It, Miranda in The Tempest and Lavinia in Titus Andronicus. However, using this approach exclusively would leave unanswered the perceived absence of little girls from early modern drama. What we find lacking in canonical Renaissance drama, especially in Shakespeare, is the kind of childhood stories that Mary Cowden Clarke provided in The Girlhood of Shakespeare's Heroines, first published between 1850 and 1852 and then as a five-volume collected edition. Cowden Clarke's fifteen narrative prequels offer psychological portraits of Shakespeare's female characters as children. The title alone grips the imagination with the promise of revealing how Shakespeare's women became who they are; the title also implies that the girlhood of Shakespeare's heroines exists outside of the plays. As Cowden Clarke reminds her readers in the preface of the 1874 edition, 'here, [Shakespeare's] women are in their girlhood, - these are their "sallet days," when they are "green in judgment," - immature, - but the opening buds of the future "bright consummate flowers" which he has given to us in immortal bloom.' ${ }^{12}$ In her tales, we get to see Katherina from Taming of the Shrew be tied up, Ophelia from Hamlet witness the death of her good friend in childbirth, and Mistress Quickly's mother make a proto-feminist argument against her husband's preference for male children. The stories are fascinating, and they exert an undeniable influence over the way we understand Shakespeare's plays, effectively acting as a form of literary criticism.

The Girlhood of Shakespeare's Heroines participated in two widespread phenomena in late nineteenth-century culture: the rise 
of Shakespearean character criticism and the fetishisation of female childhood. The Victorian propensity to treat Shakespeare's characters as real people - to psychologise them and describe their actions as if they took place in history rather than in drama - resulted in a wide variety of essays on Shakespeare's men and women in which the writers identify with them as examples of the human experience. ${ }^{13}$ Victorian women, as Gail Marshall has shown, actively engaged with Shakespeare both in their educations and in literary criticism, 'negotiating their Shakespearean legacy and attempting to plot its meaning for themselves and for their culture'. ${ }^{14}$ Before Cowden Clarke, women like Anna Jameson penned essays exploring the moral characters of Shakespeare's heroines as studies in Victorian ideals of womanhood. ${ }^{15}$ Cowden Clarke's fictional intervention into Shakespeare's world had a similar preoccupation. For Cowden Clarke, Shakespeare could not ever truly have represented girls because she saw his heroines as embodying ideal womanhood, with his plays showing them to us 'in the meridian blaze of perfection' ${ }^{16}$ They could not, regardless of their ages, truly be associated with the immaturity she associates with girlhood and still be Shakespeare's heroines.

Cowden Clarke's sense that girls are missing from Shakespeare is a product of this Victorian construction of girlhood. Like all readings, however, these tales can shut down other interpretations by suggesting that we need to look outside Shakespeare's plays, and outside early modern literature, to find representations of girls instead of recognising that early modern culture defined girlhood and childhood differently from the way Cowden Clarke did in the nineteenth century and differently from the way we do today. Nonetheless, the title of this book quite obviously combines Mary Cowden Clarke's title with a reference to Virginia Woolf's story about Shakespeare's sister Judith. It was reading Mary Cowden Clarke (in an undergraduate class not coincidentally named 'Shakespeare's Sisters') that set me up to wonder years later where to find the girls in English Renaissance literature. Her sense that they were absent from Shakespeare prompted me to look for them, to wonder whether their girlhoods looked anything like Woolf's vision of Judith Shakespeare. While Cowden Clarke was concerned that Shakespeare's women did not have recorded girlhoods, Virginia Woolf was concerned that women in Shakespeare's time had nothing but girlhoods. The story of Shakespeare's sister in A Room of One's Own is that of a little girl who grows up wanting to write but who finds herself excluded from literary culture. It ends with her committing suicide after her literary ambitions have been thwarted by her culture's restricted roles for women. ${ }^{17}$ Although Woolf visited the reading room of the 
British Museum in search of answers about women's history and literary accomplishments, she, like Cowden Clarke, ultimately relied on fiction to fill in the gaps in the historical record available to her, a move that has inspired a great deal of feminist recovery work but that has also, as Margaret Ezell cautions, led to some distortions in the way we write women's literary history. Woolf's preference for professional women writers and her privileging of printed books obscured the extent to which women participated in manuscript circulation, which in sixteenth- and seventeenth-century England was 'the standard, traditional form of intellectual exchange for men and women' and was not a private form of literary production. ${ }^{18}$ Likewise, the desire to find the independent adult women writers that Woolf wants girls like Judith Shakespeare to have had the opportunity to become has directed attention away from female childhood. Using the expanded archive of materials that is now available, this book offers an alternative vision of the construction of early modern girlhood, one that seeks to approach it on its own terms while still holding on to Cowden Clarke's interest in fictional characterisation and Woolf's concern for the historical conditions of girls and women in Shakespeare's world.

So what then was an early modern girl? For my purposes in Chapters 1 and 2, a girl is a 'girl' when she is called one, because otherwise she is a 'maid' or a 'damsel' or a 'wench' or a 'lass' or any one of the other host of terms in early modern English used to constitute and name a female human being as a female human being. The reason I have taken this approach is that I have become increasingly aware of the efficacy of Ludwig Wittgenstein's observation that 'the meaning of a word is its use in the language'. Words come to mean what they mean because speakers use them in particular speech acts, and the central tenet of this book is that calling a person a 'girl' in early modern England constituted her as feminine in a way that was different from calling her a 'woman' or a 'lass' or a 'maid'.

As I show in Chapter 1, 'girl' was part of a rich vocabulary of female youth that was multiple, complex and multivalent. The multiplicity of positions available to female human beings in language was part of the challenge that the discourse of girlhood posed to the second triad that this book is looking to complicate, that of the 'maid', 'wife' and 'widow'. This linear marital progression is the traditional way scholars have studied women's life cycles, but feminist historians have frequently expressed discomfort with the way this categorisation defines women according to their (hetero)sexual and marital status. Even the truly excellent work on single women that has come out in the past few years still conceptualises female lives in terms of their lack of a husband, 
thereby normalising marriage as the default path. ${ }^{19}$ The benefit of thinking about female lives via girlhood is that it does not automatically figure them in terms of their marital status.

Whereas a large body of feminist literary criticism has focused on early modern women broadly speaking, or on young women as daughters, maids, virgins or marriageable romantic heroines, I turn to the category of the 'girl' to recognise the ways early modern writers mediated the gap between what women were supposed to be and the historical conditions in which they lived. Following the Protestant Reformation, the dominant religious ideology constructed all women as 'married or to be married', ${ }^{20}$ and the dissolution of the monasteries meant that women could no longer choose the Church as a vocation. However, as Amy Louise Erickson points out, most adult women were unmarried at any given time in early modern England either because they were widowed or because they had never been married. ${ }^{21}$ This contradiction, as well as the elimination of virginity as an institutionally sanctioned life path, produced a linguistic tension over the inapplicability of terms like 'maid' and 'wife' to female individuals whose lives challenged the social and legal fiction that all women would proceed from virginity to marriage to widowhood. While the culture reconfigured its perceptions of women's life cycles, the fluidity of the discourse of girlhood opened up imaginative opportunities for constructing female identities that cut across those rigid categories. Far from being the only way of organising women's life stages, the 'maid, wife, widow' triad was constantly dissolving in the face of an alternative vocabulary.

Chapter 1 accordingly begins at the level of language and charts the emergence of 'girl' into early modern English, tracing two major shifts in the development of the vocabulary of female youth. The first shift began in the early sixteenth century and involved the proliferation of specialised terms for female children. Following this period of elaboration, a second shift took place in the mid-seventeenth century, when 'girl' and the other terms in its semantic network began to be defined as separate categories of female youth. 'Girl' subsequently came to be defined as the female age category that it largely is today. In the transitional period, however, 'girl' functioned more as a gender category than as an age category, and a 'girl' could be anyone from a female infant to an unruly adult. This flexibility, I argue, provided the terminology necessary for writers like Thomas Heywood to describe dynamic, subversive female characters like Bess Bridges, the cross-dressing heroine of The Fair Maid of the West, or a Girl Worth Gold (c. 1600). Rather than following a linear progression from 'maid' to 'wife' to 'widow', Bess moves between categories of female identity. She can be a 'maid' - a young and virtuous 
virgin - but also a 'wench', a 'sweet lass', a 'tanner's daughter', 'a she-drawer' and 'a girl worth gold'.

Having examined the vocabulary of girlhood in the first chapter, in the second chapter I investigate the way the discourse of girlhood produced gendered identities. Will Fisher's work on the prosthetic markers of masculinity has shown that early modern culture perceived boys as differently gendered from men, marking them off from the realm of adult masculinity through their beardlessness and other sexual characteristics. Early modern culture likewise perceived girls as differently gendered from women. Fisher in fact anticipated this study in one of his footnotes, remarking, 'It may well be ... that there was a corresponding split in the production of femininity in early modern England, in which case sexual distinctions would have been fourfold. ${ }^{22}$ What I have discovered is that the split in the production of femininity did not produce a fourfold model but rather pulled apart the tripartite one. Girls did not fit into the sex-gender system so much as they disrupted it. By offering an alternative construction of femininity, girlishness exposed womanhood as a social backformation. I use the description of female characters as 'girls' in George Gascoigne's The Adventures of Master F. J., Shakespeare's The First Part of Henry the Sixth and Thomas Middleton and Thomas Dekker's The Roaring Girl to show that early modern writers turned to the category of the 'girl' to account for female characters who were not only sexually but also, more importantly, socially and politically resistant to occupying their womanly place within the social hierarchy.

Whereas Chapters 1 and 2 focus on the ways girlhood functioned as a discursive gender category, my last three chapters focus on representations of female childhood. In moving from 'girl' in quotation marks to one aspect of the way 'girl' could be used - as a designation for female infants and children - I am making a conscious decision to pick up on the tensions between the way 'girl' functioned as a signifier that could indicate unruly femininity without regard to age and its simultaneous associations with female youth. To look at female children, then, is to provide the other side of the story. Early modern drama and life writing participated in the construction of girlhood as a particularly gendered time of life, and my final chapters explore the way 'the girl' could be represented as a particularly gendered kind of child.

Chapter 3 looks at female infants in early modern drama. Shakespeare's Pericles, The Winter's Tale and Henry VIII and Thomas Middleton's A Fair Quarrel and A Chaste Maid in Cheapside were part of a minor vogue on the early seventeenth-century stage for using infants as stage props. Using these plays as a starting point, I argue that early 
modern representations tend to figure infants as problematically gendered and, consequently, as problematically human. By exploring the connections between childhood and gender in performance via infancy, this chapter circumvents the absence of female bodies from the stage to explore the way early modern notions of humanity were rooted in a language of gender. To be spoken of as human, I argue, was to be spoken of as male or female.

Although initially I believed that, aside from infants, female children rarely appeared on the early modern stage, it turned out that young girl characters were not entirely absent; I just needed to look a little harder for them. To date, I have found seventeen plays that include young girls coded as what we would call pre-adolescent children. Like infants, young, pre-adolescent girls appear regularly in plays, from interludes to masques, but the distinctions between girlhood and womanhood can be more difficult to uncover because female life stages were less public and textually documented than male ones. As a result, much of what has been written as the history of childhood in pre-modern Europe has actually been the history of boyhood. 'Boys', as Philippe Ariès rightly pointed out in 1960, 'were the first specialized children. ${ }^{23}$ This does not mean, however, that childhood was the peculiar province of boys, or that female children did not experience childhood; in fact, it suggests something quite different - that childhood was viewed as feminine and that boys were being differentiated from the generic category of the 'child'. Scholars were once tempted to relegate Ariès to the academic dustbin, but recent historians of childhood have come to recognise his fundamental contributions to the field. ${ }^{24}$ His most eloquent apologist is Hugh Cunningham, who acknowledges the problems with Ariès's methodology but finds his questions, and indeed many of his answers, compelling. As Cunningham points out, Ariès's greatest contribution to the history of childhood was his insistence that childhood had a history. ${ }^{25}$ Like Cunningham, I see Ariès as offering crucial insights into the shifting construction of childhood in the seventeenth century. What Ariès means when he calls boys specialised children is that they were initiated into a separate cultural sphere where schooling and education isolated them from adult cares while also preparing them for their future lives as men. This difference was expressed in their clothing and marked by their transition from coats to breeches. Girls, on the other hand, 'were distinguished [from adult women] only by the false sleeves, abandoned in the eighteenth century, as if childhood separated girls from adult life less than it did boys'. ${ }^{26}$ Ariès correctly points out that in England girls went to petty schools, but not to grammar schools, and they had no equivalent ceremony to the breeching of boys. 
The problem with Ariès's formulation of his argument is that it works against his historicist aims. He takes a static definition of childhood and talks about its emergence and absence rather than uncovering the existence of different constructions of childhood over time, adopting a fossilised vision of childhood that carries over into his analysis of gender difference. Ariès defines childhood by the experience of boys, talking as if girls could not have had one simply because theirs did not correspond as closely to modern notions of childhood as the experiences of early modern boys. What I would point out is that rather than making girls un-childlike, the social structures of their childhoods were actually very much in keeping with the existing constructions of early modern childhood that Ariès represents as gradually being superseded over the course of the early modern period. ${ }^{27}$

For girlhood to become a distinctly gendered life-stage, childhood first had to be disassociated from femininity and femaleness in general, a process that should be seen as part of a larger trend traced by historians of childhood. Although scholars continue to disagree about the chronological development of the sentimental idea of the child, most agree that the Western world's view of childhood changed at some point after the sixteenth century. ${ }^{28}$ Adults no longer saw childhood as a period to be got through as quickly as possible and instead saw it as a state of innocence to be preserved and protected. For historians of girlhood like Sally Mitchell, the full fruition of this shift came with the late Victorian production of a separate culture for girls, including special books, clubs, sports and schools, a movement in which Mary Cowden Clarke participated by writing about girls and positioning Shakespeare as girls' literature. In an article for the Girl's Own Paper in 1887, Cowden Clarke suggests that Shakespeare is a 'poet-teacher' whose female characters serve as examples of how young women should behave. She writes, 'To the young girl, emerging from childhood and taking her first step into the more active and self-dependent career of woman-life, Shakespeare's vital precepts and models render him essentially a helping friend. ${ }^{29}$ As Mitchell convincingly demonstrates, this new sphere of girlhood became a kind of 'provisional free space' for young women before they entered into the full patriarchal world of womanhood and marriage. ${ }^{30}$

The difference between the Victorian culture of girlhood and the phenomenon that I am describing is that the goal of 'girling' and 'boying' children in the early modern period was usually not to preserve their childhoods but to propel them toward adult manhood and womanhood. As Cunningham points out, one of the hallmarks of child-centred culture was that it downplayed sexual distinctions in favour of an idealised ungendered child who had not yet fallen into the adult world of 
sexual relations. ${ }^{31}$ This contrasts with the early modern perception of all children as feminised, although the language of the seventeenth century shows a movement toward specifying children's gender rather than obscuring it.

It was not, however, that female children were undifferentiated from adult women, as a simplistic interpretation might imply; their progress into adulthood was simply less culturally and textually legible because it was imagined as continuous rather than initiated by a sharp break. ${ }^{32}$ As Anne Buck notes in her history of children's costume, 'For girls there was no break with childhood comparable with the breeching of boys; they passed gradually into adult fashion. ${ }^{33}$ Nonetheless, growing older made a material difference to female lives. The Lawes Resolution of Women's Rights (1632), for example, records the different ages at which young women received legal rights, including the ages at which they could consent to marriage, lay claim to inherited property, and escape the legal compulsion to serve as apprentices. Bodily changes would also have brought about tangible differences in girls' lives. Early modern ideas about the physical maturation of girls can be found in midwifery manuals, which recognised that girls were physically different from adult women. When Jane Sharp distinguishes between the bodies of pre-pubertal girls and mature women's bodies in The Midwives Book (1671), she links the physical differences to the onset of the menses: 'The womb is small in Maids, and less than their bladder, neither is the hollow compleat but groweth bigger as the body doth. In Maids of ripe years it is not much bigger than you can comprehend in your hand; unless when they come to be with Child, yet it grows by reason of their courses. ${ }^{34}$ Sharp imagines this physical transformation as taking place over time, but she still portrays girls' bodies as materially specific to female youth rather than as miniature versions of adult women. Like Beauvoir, Sharp's manual exhibits an awareness that girls become women and that female bodies and female identities change over time. The recognition of biological differences between female bodies (even the same person's female body) works against the conflation of all female human beings into the same social category.

Historians generally agree, however, that menarche was neither a rite of passage nor an absolute break with youth. Sara Mendelson and Patricia Crawford specifically do not organise their discussion of women's life cycles around such physical changes. They write, 'The physical rites de passage - menarche, pregnancy, and menopause - have not been used as markers of stages, because we found no women who conceptualized their lives in those terms. ${ }^{35}$ Nonetheless, although not as readily visible as the beards Will Fisher associates with Renaissance 
masculinity, the onset of menstruation fulfilled a similar role as a marker of reproductive maturity. ${ }^{36}$ In The Historie of Life and Death, Francis Bacon explicitly associates menstruation in women with the development of beards in men - both signs of reproductive capacity. Noting that male and female children go through puberty at 'about twelve or fourteen years of age', Bacon locates the transition to adulthood for both men and women in the development of reproductive ability. 'To be able for generation' is the first consequence of puberty, followed by 'the flowing of the menstrua, to have hairs about the legs and arm-holes, to put forth a beard'. ${ }^{37}$ The rest of Bacon's discussion of 'the difference of youth and old age' focuses on male-specific life changes, but he interestingly conflates the acquisition of gendered secondary sex characteristics. Moreover, he even marks the cessation of the menses and lost reproductive capacity as a marker of old age. ${ }^{38}$ Legal and medical texts make it clear that the absence of differentiation in dress did not mean that other forms of differentiation did not take place.

As childhood became less associated with femininity in general and split instead into boyhood and girlhood (two different types of childhood), what I see happening is a move to figure 'girls' in more modern terms. However, our own positive associations with what it means to have 'an idea of childhood' should not blind us to the historical implications of what it meant for girls to be considered specialised children. What Ariès describes as 'a sentiment of childhood' might more properly be termed what Cunningham identifies as a 'middle-class ideology of childhood', a set of beliefs held together by the elevation of the affective, nuclear family: 'At the heart of this ideology lay a firm commitment to the view that children should be reared in families, a conviction that the way childhood was spent was crucial in determining the kind of adult that the child would become, and an increasing awarenesss that childhood had rights and privileges of its own. ${ }^{39}$ What has been largely unrecognised (aside from Cunningham) is that whatever else Ariès argued about the idea of childhood in the seventeenth century, he did not see it as unequivocally positive. Of the modern family Ariès wrote, 'This family has advanced in proportion as sociability has retreated... Everywhere it reinforced private life at the expense of neighbourly relationships, friendships, and traditional contacts. ${ }^{30}$ The nuclear family, built around the special category of the child, comes at the expense of sociability. For Ariès, this loss represents a high price.

The construction of girlhood in the Renaissance, I am suggesting, also undergoes historical changes that come with a high price. In Chapter 4, I offer a literary history that charts the broad historical trajectory of the way early modern dramatic genres positioned female children in 
the context of competing understandings of childhood. I argue that the subversive potential of girlishness on the early modern stage became neutralised as girlhood became increasingly defined as a time of life rather than a gendered state of being, and this shift can be traced in the gradual decline of dynamic girl characters in morality plays and interludes to the later public stage genres of comedy, history and tragedy. Dramatists do not seem to have been interested in staging the process through which infants became girls, or girls became women, but the earlier morality plays include a number of fully realised female children. With the introduction of the purpose-built theatres in London, the vocal 'naughty girls' of Tudor interludes like Dalila in Nice Wanton and Abra in Jacob and Esau gave way to static, mostly silent female children who functioned predominantly as sentimental objects. When drama sought to emphasise the adult social world rather than the individual's spiritual development, the potential of girlhood for disruption and subversion became significantly less palpable. The stronger the association between girls and the middle-class ideology of childhood, the less prominent the voices of girl characters became on the stage.

Because the representation of girls' voices in drama was filtered through the perspective of male playwrights, my final chapter focuses on the way women represented their own childhoods, raising questions about where and how girls spoke in early modern writing and what kinds of cultural work their voices did. If coming-of-age stories were largely absent from public drama, they were not absent from women's writing. In contrast to the static, predominantly symbolic role that female children played on the public stage, female youth appears prominently in early modern life writing. An autobiographical letter by Margaret Clifford, Lady Grace Mildmay's private writings, Lady Anne Clifford's diary and Rose Throckmorton's manuscript Certain Old Storyes provide some access to girls' voices, albeit mediated through the retrospective lens of adult memories. I read these texts to think about the way girls and girlhood functioned as part of broader strategies for narrating female lives. At the very least, this genre of women's writing enables us to see how some women constructed their own girlhoods as gendered experiences and how they saw them as producing their future identities as adult women. Although much of this book focuses on the way girls were represented in men's writing, Chapter 5 seeks to give space to the women who had first-hand knowledge of what it meant to be a girl in early modern England.

Having set out to find girls in early modern literature, I seem to have found them everywhere, lurking in popular plays and buried in obscure pamphlets. At the same time, the more I see them, the more I realise that 
'girls', like 'women', occupy an unstable place in a network of shifting gender identities. The category of the 'girl' was neither monolithic nor easily defined; the fair maid and the golden girl, the female infant on the stage, the saucy servant in a Tudor interlude and the great-greatgreat-granddaughter copying her ancestor's autobiography were all part of a society in which girlhood was under construction. Sixteenth- and seventeenth-century English writers struggled to articulate their understandings of female youth, and girls in turn challenged them to renegotiate the boundaries of the sex-gender system. What follows is an attempt to rise to their challenge.

\section{Notes}

1. Monique Wittig, 'One Is Not Born a Woman', in Henry Abelove, Michèle Aina Barale and David M. Halperin (eds), The Lesbian and Gay Studies Reader (New York: Routledge, 1993), p. 105.

2. Luce Irigaray, 'The Power of Discourse and the Subordination of the Feminine', in Margaret Whitford (ed.), The Irigaray Reader (Oxford: Blackwell, 1991), p. 119.

3. Stephen Orgel, 'Nobody's Perfect, Or Why Did the English Stage Take Boys for Women?', South Atlantic Quarterly 88 (1989), pp. 7-29.

4. Stephen Orgel, Impersonations: The Performance of Gender in Shakespeare's England (Cambridge: Cambridge University Press, 1996).

5. Phyllis Rackin traced the transition from early Renaissance plays in which cross-dressed female characters enabled homoerotic desires to later plays in which they reinforced heterosexual norms, while Lisa Jardine explored the transvestite theatre as an extension of early modern sexualities and class structures. At the same time, many New Historicists, especially Stephen Greenblatt, were drawn to Thomas Lacqueur's work on the Galenic one-sex model and came to see boys playing women on stage as extension of the medical view that men and women's bodies were morphologically part of a single sex. Theatre historians like Michael Shapiro, on the other hand, stressed economic factors and the connections between boy players and early modern apprenticeship practices. Just a few of the important articles and books include: Phyllis Rackin, 'Androgyny, Mimesis, and the Marriage of the Boy Heroine on the English Renaissance Stage', PMLA 102 (1987), pp. 29-41; Lisa Jardine, 'Twins and Travesties: Gender, Dependency and Sexual Availability in Twelfth Night', in Susan Zimmerman (ed.), Erotic Politics: Desire on the Renaissance Stage (New York: Routledge, 1992), pp. 27-38; Laura Levine, Men in Women's Clothing: Anti-theatricality and Effeminization, 1579-1642 (Cambridge: Cambridge University Press, 1994); Stephen Greenblatt, 'Fiction and Friction', in R. S. White (ed.), Twelfth Night (New York: St. Martin's Press, 1996), pp. 92-128; Juliet Dusinberre, 'Boys Becoming Women in Shakespeare's Plays', Shakespeare Studies 36 (1998), pp. 1-28; and Peter Stallybrass, 'Transvestism and the Body Beneath: Speculating on the Boy Actor', in Susan Zimmerman (ed.), 
Erotic Politics: Desire on the Renaissance Stage (New York: Routledge, 1992), reprinted with some emendations in Ann Rosalind Jones and Peter Stallybrass, Renaissance Clothing and the Materials of Memory (Cambridge: Cambridge University Press, 2000), pp. 207-19.

6. This and all future Shakespeare quotations, unless otherwise noted, are taken from The Norton Shakespeare, ed. Stephen Greenblatt, Walter Cohen, Jean E. Howard and Katharine Eisaman Maus (New York: Norton, 1997).

7. Toril Moi, What Is a Woman? And Other Essays (Oxford: Oxford University Press, 1999), p. 82.

8. Ibid. p. 37.

9. In contemporary feminist studies, this exclusion manifests itself most visibly through the marginalisation of women of colour and women in developing countries. See especially Chandra Mohanty, Feminism Without Borders: Decolonizing Theory: Practicing Solidarity (Durham, NC: Duke University Press, 2003).

10. For a discussion of the way that trans women have had their bodies and social identities questioned and excluded by contemporary feminists, see Julia Serrano, Whipping Girl: A Transsexual Woman on Sexism and the Scapegoating of Femininity (Emeryville, CA: Seal Press, 2007).

11. Mark Lawhorn, 'Children in Shakespeare's Plays: An Annotated Checklist', in Kate Chedgzoy, Susanne Greenhalgh and Robert Shaughnessy (eds), Shakespeare and Childhood (Cambridge: Cambridge University Press, 2007), pp. 233-49. Excluding female infants because they were not actually personated by actors, Thomas A. Pendleton notes that Clarence's daughter is the 'only female child's role' in Shakespeare. See his article 'How Many Children Had William Shakespeare?', Shakespeare Newsletter 58:1 (2008), p. 25. For two brief references to Clarence's daughter, see Catherine Belsey, 'Shakespeare's Little Boys: Theatrical Apprenticeship and the Construction of Childhood', in Bryan Reynolds and William N. West (eds), Rematerializing Shakespeare: Authority and Representation on the Early Modern English Stage (Basingstoke: Palgrave, 2005), p. 56, and her 'Little Princes: Shakespeare's Royal Children', in Kate Chedgzoy, Susanne Greenhalgh and Robert Shaughnessy (eds), Shakespeare and Childhood (Cambridge: Cambridge University Press, 2007), p. 32.

12. Mary Cowden Clarke, The Girlhood of Shakespeare's Heroines; in a Series of Tales (New York: G. P. Putnam's Sons, 1874), p. 2.

13. See Brian Vickers, 'The Emergence of Character Criticism', Shakespeare Survey 34 (1981), pp. 11-21, and Christy Desmet, 'Character Criticism', in Stanley Wells and Lena Cowen Orlen (eds), Shakespeare: An Oxford Guide (Oxford: Oxford University Press, 2003), pp. 351-62.

14. Gail Marshall, Shakespeare and Victorian Women (Cambridge: Cambridge University Press, 2009).

15. Anna Jameson, 'Characteristics of Women, Moral, Poetical, and Historical (London): Introduction, Portia, Helena, Hermione, Cleopatra', in Ann Thompson and Sasha Roberts (eds), Women Reading Shakespeare, 16601900 (Manchester: Manchester University Press, 1997), pp. 66-80. For a discussion of her techniques, see Marshall, Shakespeare and Victorian Women, pp. 6-7. 
16. Cowden Clarke, The Girlhood of Shakespeare's Heroines, p. 2.

17. Virginia Woolf, A Room of One's Own (San Diego: Harcourt Brace, 1922), pp. 46-8.

18. Margaret Ezell, 'The Myth of Judith Shakespeare: Creating the Canon of Women's Literature', New Literary History 21 (1990), p. 587. See also her book Writing Women's Literary History (Baltimore: Johns Hopkins University Press, 1996), pp. 39-65.

19. Sara Mendelson and Patricia Crawford avoid dividing their account of women's lives into these categories in Women in Early Modern England, 1550-1720 (Oxford: Oxford University Press, 1998), pp. 75-123. The two recent anthologies, one literary and one historical, on unmarried women are: Laurel Amtower and Dorothea Kehler (eds), The Single Woman in Medieval and Early Modern England: Her Life and Representation (Tempe: Arizona Center for Medieval and Renaissance Studies, 2003), and Judith M. Bennett and Amy M. Froide (eds), Singlewomen in the European Past, 1250-1800 (Philadelphia: University of Pennsylvania Press, 1999).

20. This sentiment famously appears in Thomas Edgar, The Lawes Resolutions of Women's Rights (London, 1632), sig. B3v.

21. Amy Louise Erickson, Women and Property in Early Modern England (New York: Routledge, 1993), pp. 8-9.

22. Will Fisher, Materializing Gender in Early Modern English Literature and Culture (Cambridge: Cambridge University Press, 2006), pp. 188-9, n. 19.

23. Philippe Ariès, Centuries of Childhood, trans. Robert Baldick (New York: Vintage, 1962), p. 58.

24. Recent re-explorations of Ariès include Margaret L. King, 'Concepts of Childhood: What We Know and Where We Might Go', Renaissance Quarterly 60 (2007), pp. 371-407; Hugh Cunningham, Children and Childhood in Western Society since 1500 (New York: Longman, 1995); and Colin Heywood, A History of Childhood: Children and Childhood in the West from Medieval to Modern Times (Cambridge: Cambridge University Press, 2001). See Cunningham for a full account of the development of the history of childhood, including a lucid explanation of the disagreements between scholars who are often grouped together under the 'sentiments' approach. For alternative views of pre-modern childhood as essentially continuous with contemporary attitudes toward children, see Linda Pollock, Forgotten Children: Parent-Child Relationships 1500-1900 (Cambridge: Cambridge University Press, 1983) and A Lasting Relationship: Parents and Children Over Three Centuries (Ann Arbor: University of Michigan, 1987); Nicholas Orme, Medieval Children (New Haven: Yale University Press, 2001).

25. See Cunningham, Children and Childhood, esp. pp. 61-74. Unlike Ariès, Cunningham locates the major shift in ideas about childhood in the eighteenth century.

26. Ariès, Centuries of Childhood, p. 58.

27. Ibid. pp. 41-78.

28. Cunningham, Children and Childhood, pp. 61-74. Cunningham dates the shift toward child-centred culture to the eighteenth century, although he acknowledges that it has roots in the preceding centuries. Margaret L. King, on the other hand, cites a scholarly consensus that changes began in the 
seventeenth century. In contrast, Linda Pollock and Nicholas Orme stress the continuity of the past with the present, seeing pre-modern attitudes toward children as similar to today's. Pollock focuses on the treatment of actual children by adults. Orme is likewise interested in actual children's lives more than the concept of childhood, as is Barbara Hanawalt, who provides one of the most sustained analyses of the impact of gender on medieval children in her Growing up in Medieval London: The Experience of Childhood in History (Oxford: Oxford University Press, 1993).

29. Mary Cowden Clarke, 'Shakespeare as the Girl's Friend', in Ann Thompson and Sasha Roberts (eds), Women Reading Shakespeare, 1660-1900 (Manchester: Manchester University Press, 1997), p. 101. Deanne Williams at York University in Toronto is currently working on a study of early modern girlhood entitled Girls Own Shakespeare that will examine both constructions of female childhood in the period and Shakespeare as girls' literature.

30. Sally Mitchell, The New Girl: Girls' Culture in England 1880-1915 (New York: Columbia University Press, 1995), p. 3. See also Jane Hunter, How Young Ladies Became Girls: The Victorian Origins of American Girlhood (New Haven: Yale University Press, 2002).

31. Cunningham, Children and Childhood, p. 75.

32. It is worth noting that the absolute break between boyhood and manhood was fictional. Boys, like girls, went through other transitional phases, such as weaning, teething and learning to walk, and they also switched into doublets before leaving off skirts for breeches. Moreover, breeching was not irreversible; a young boy could be put in breeches for a special occasion and then returned to coats until he was older, and the age of breeching varied depending upon family tradition, personal sentiment and the boy's height.

33. Although the modern observer often has difficulty determining the gender of children in early modern portraits, girls and boys were sometimes distinguished through subtle markers. For accounts of the differences between children's attire and adult fashion and of the differences between the dress of boys and girls, see Anne Buck, Clothes and the Child: A Handbook of Children's Dress in England 1500-1900 (New York: Holmes \& Meier, 1996), and Jan Baptist Bedaux and Rudi Ekkart (eds), Pride and Joy: Children's Portraits in the Netherlands 1500-1700 (Amsterdam: Ludion Press, 2000).

34. Jane Sharp, The Midwives Book, or the Whole Art of Midwifry Discovered, ed. Elaine Hobby (Oxford: Oxford University Press, [1671] 1999), p. 35.

35. Mendelson and Crawford, Women in Early Modern England, p. 7.

36. Will Fisher argues that beards are a prosthetic marker of masculinity, and he shows that beards were believed to be a sign of reproductive capacity. See especially his chapter 'The Renaissance Beard: Masculinity in Early Modern England' in Fisher, Materializing Gender, pp. 32-79.

37. Francis Bacon, The Historie of Life and Death, in The Works of Francis Bacon (Philadelphia: Carey and Hart, 1842), p. 511.

38. The age of the onset of menstruation was rarely recorded, but it appears to have been later than today. Menarche may have occurred as late as sixteen or seventeen, and Simon Forman records that his wife did not get her 'courses' until after their marriage. When she does, Forman enthusi- 
astically notes the beginning of his wife's menstrual cycle in his diary and looks forward to having children. See A. L. Rowse, Simon Forman: Sex and Society in Shakespeare's Age (London: Weidenfeld \& Nicolson, 1974).

39. Cunningham, Children and Childhood, p. 41.

40. Ariès, Centuries of Childhood, p. 406. 


\section{'A wentche, a gyrle, a Damsell': Defining Early Modern Girlhood}

Puella, a wenche.

Puellaris, re, chyldishe.

Puellascere, to wax yong again, to be maidenly.

Thomas Elyot, 1542

Puella, ae, foemini, gene. A wentche, a gyrle, a Damsell.

Puellaris, re, chyldyshe, of gyrles, propre to girles and wentches.

Puellariter, lyke a wentche or gyrle, childyshely.

Puellasco, scere, to waxe yonge againe, to bee maidenly, to waxe gyrlyshe.

Puellula, ae, f.g.a. littell gyrle, a wentche.

Thomas Cooper, 1548

When Thomas Cooper set about revising Thomas Elyot's Latin-English dictionary Bibliotheca Eliotae, his aim was to 'castigate' and 'augment' the original to give 'the true significacions of wordes'. ${ }^{1}$ Among the words that Cooper castigated and augmented was the Latin noun puella, whose entry Cooper expanded to provide a fuller, if not a truer, set of English equivalents. ${ }^{2}$ Where Elyot had given the English translation for puella simply as 'a wench' in 1542, Cooper gave the entry six years later as 'a wentche, a gyrle, a Damsell'. This extension was part of Cooper's overall attempt to give expanded translations for a number of Latin words, and the addition of 'girl' to entries related to puella was a consistent feature of Cooper's revisionary activity. To Elyot's entry for the Latin verb puellascere, 'to wax yong again, to be maidenly', Cooper added 'to waxe gyrlyshe', once again giving the word 'girl' as an alternative for puella. In addition to inserting 'girl' into Elyot's existing entries, Cooper supplemented the section of words related to puella with entries for puellariter, 'lyke a wentche or gyrle', and puellula, 'a littell gyrle, a wentche'. At the same time, Cooper increased his dictionary's emphasis on the gendering of the adjective puellaris by expanding Elyot's entry of 'chyldishe' to read 'chyldyshe, of gyrles, propre to girles 
and wentches'. Rather than emphasising childhood in general, Cooper's entry for puellaris defined the word specifically in relation to female childhood.

In the process of defining puella in more detailed and gender-specific terms, Cooper took part in a larger trend in sixteenth-century English. Although 'girl' had initially been used to refer to a child of either sex in Middle English, by the early sixteenth century 'girl' had come to refer exclusively to female individuals, a linguistic transformation that coincided with the beginning of a cultural redefinition of female youth. Appearing with increasing frequency in print and manuscript texts, 'girl' began a rise to prominence that would eventually establish it as the primary term for a female child in the eighteenth and nineteenth centuries. Along the way, however, sixteenth- and early seventeenth-century definitions of 'girl' were slippery and contested. Writers and the culture to which and from which they were speaking were trying out a variety of words, and before 'girl' emerged as the dominant one, a number of others were circulating and competing for prominence. This chapter traces the shift from the sixteenth-century proliferation of synonyms for 'girl' to a time in the mid-seventeenth century when 'girl' and the other words in its semantic network began to be defined against each other as separate categories of female youth.

I argue that these lexical innovations were inseparable from the renegotiations of gender and age taking place in early modern society. As Stanley Cavell points out, names matter precisely because learning them teaches speakers to understand the social significances and ideologies behind them:

In learning language you learn not merely what the names of things are, but what a name is; not merely what the form of expression is for expressing a wish, but what expressing a wish is; not merely what the word for 'father' is, but what a father is; not merely what the word for 'love' is, but what love is. In learning language, you do not merely learn the pronunciation of sounds, and their grammatical orders, but the 'forms of life' which make those sounds the words they are, do what they do-e.g. name, call, point, express a wish or affection, indicate a choice or an aversion, etc. ${ }^{3}$

To learn to identify a 'father' entails not only learning to fit a sign to an object, but also the set of criteria that govern the communal customs for attaching the two together. A modern speaker knows that 'damsel' is a synonym for 'girl', but also understands that it is an inappropriate term for labelling identity in today's world. At the same time, the speech act of calling someone a 'damsel' could potentially redefine the term and make a contemporary person into one.

As synchronic variations gave rise to diachronic changes in the 
conventions governing speech, the cumulative speech acts of early modern speakers came to shape the imaginative possibilities for what it meant to be an early modern girl. 'Girl' evolved into a gender-specific term in the context of a vocabulary that was under construction. Among the words circulating in the rich and varied vocabulary of female youth were 'girl', 'maid', 'wench', 'bird', 'lass', 'damsel', 'pucelle', 'daughter', 'trull', 'pigeon', 'tit', 'slut', 'miss', 'tendril', 'stammel', 'woman child', 'kitty', 'prill', 'tib', 'Gillian', 'mop', 'frotion', 'winklot', 'gixy', 'whims(e) y', 'zitella', 'vriester' and 'fraulen'. ${ }^{4}$ The plurality of terms was partly the result of English borrowings from other languages, making foreignlanguage dictionaries an important resource for investigating the development of this vocabulary. 'Fraulen' clearly derived from the German fräulein, the diminutive of frau, or wife, and 'zitella' was imported from early modern Italian. It is important to keep in mind, however, that although wide ranging, this list, compiled from Grzegorz Kleparski's impressive study of synonyms for girl/young woman, can be a bit misleading for scholars interested specifically in female children. Many of the terms referred to both adult women and female children, and some only occur in a few texts. The most commonly used terms were 'girl', 'maid', 'wench' and 'woman child', though 'lass' and 'damsel' also appeared regularly. Given the scholarly emphasis on the organisation of early modern women's life cycles into the categories of 'maid', 'wife' and 'widow', we might expect 'maid' to be the default term for 'young female human being' in early modern English, but this was not the case. Although the female category 'maiden' was arguably the most important category of female youth in medieval England, it no longer held such a dominant position in the sixteenth century. ${ }^{5}$

'Girls' could be grouped together with 'maids' as unmarried women, yet 'girls' could also be grouped with 'whores', since a sexually active 'girl' was not a 'maid'. As soon as one criterion, such as age or marital status, had been established, the connection dissolved with the introduction of another criterion, such as virginity or behaviour. It would be a mistake to see stable boundaries between the terms because they were not sustained by early modern speakers. Instead, we need to pay attention to the way those boundaries were established at particular moments and the way they were dissolved at others. Words that signified one way in one context could signify differently in another. In Robert Herrick's 'Upon Jone and Jane', for example, the title characters are both girls and wenches (and neither word is complimentary):

Ione is a wench that's painted;

Ione is a Girle that's tainted;

Yet Ione she goes 
Like one of those

Whom purity had Sainted.

Iane is a Girle that's prittie;

Iane is a wench that's wittie;

Yet, who wo'd think,

Her breath do's stinke,

And so it doth? that's pittie. ${ }^{6}$

Herrick uses 'wench' and 'girl' interchangeably here to designate a woman of lower social standing who is 'tainted' through sexual activity. In contrast, when Titus says to Lavinia in Shakespeare's Titus Andronicus 'Bear thou my hand, sweet wench, between thine arms', 'wench' functions as a term of endearment and sign of fatherly authority (3.1.281). Much as with the use of the word 'thou', context is crucial; a father calling his daughter a 'sweet wench' suggests affection, whereas Herrick's designation of a woman as 'wench' functions as mockery. This contrast can also be seen in The Fair Maid of the West, Part I. When Spencer calls his beloved Bess a 'wench', he does so affectionately (1.2.86); when the character Roughman tries to usurp Bess's privileges as tavern owner and addresses her with the epithet 'wench', he is being rude (2.1.94). ' Distinctions based on age between 'girls' and 'women', as well as between 'girls' and 'lasses', 'damsels' and 'maids', are clearly relational and intertwined with other contextual factors, including social status, sexuality, familial ties, occupation and historical position.

In the context of this shifting semantic network, 'girl' emerged as a multifaceted category for describing aspects of the female life cycle that did not fit into a marital teleology. 'Girl' could define female individuals not only in relation to men, but also in relation to each other. When Celia in Shakespeare's As You Like It resolves not to allow Rosalind to suffer banishment alone, Celia explicitly denies her ties to her father the Duke, who has ordered Rosalind to leave the court. Chiding Rosalind for her passivity in the face of the Duke's sentence, she describes their friendship in vivid language:

Rosalind, lack'st thou then the love

Which teacheth thee that thou and I am one?

Shall we be sundered? Shall we part, sweet girl?

No. Let my father seek another heir.

Therefore devise with me how we may fly,

Whither to go, and what to bear with us.

Celia's rhetorical move of calling Rosalind 'sweet girl' harkens back to a golden age of female friendship, a time before Rosalind's desire for 
Orlando separates the two female friends through heterosexual desire. Throwing off the demands of daughterly duty, Celia constructs a sense of female kinship, co-opting the traditional language of marriage and applying it to friendship. Instead of marriage, it is friendship that cannot be put asunder, and instead of husband and wife, two female characters are described as 'one'. ${ }^{8}$ As Valerie Traub points out, Celia's lines appropriate the Anglican marriage ceremony's line 'Those whom God hath joined together, let no man put asunder', thus reinterpreting its heterosexual valences in the service of same-sex erotic friendship. Celia invokes a time when she and Rosalind were inseparable, an image she used earlier when imploring the Duke to rethink Rosalind's banishment. Celia pleads:

We still have slept together,

Rose at an instant, learned played, eat together,

And wheresoe'er we went, like Juno's swans

Still we went coupled and inseparable.

Celia attempts to recapture and hold on to her friendship with Rosalind at a moment when it is doubly threatened by the Duke's banishment and Rosalind's newly kindled love for Orlando. The image of Celia and Rosalind as 'Juno's swans', 'coupled and inseparable', evokes a powerful image of female friendship that Celia uses to produce a nostalgic narrative of growing up with Rosalind as her companion. Traub has noted that women evoke female unity only at moments of the dissolution of female bonds and suggests that erotic female love comes into view only in so far as it is lost. ${ }^{9}$ What I would emphasise is the extent to which the language of girlhood makes that legibility possible. Relegated to the past or surviving into the present, the discursive category of the 'girl' makes it possible for Celia to articulate her past bond with Rosalind at the same time that heterosexual love threatens to cleave them apart.

Even when used in the context of service, 'girl' could function as a marker of intimacy and affection between mistresses and servants, as in Shakespeare's Antony and Cleopatra. Although focused on memorialising Antony, Cleopatra's speeches following his death are often directed at her female serving women. Using 'girls' and 'women' interchangeably, Cleopatra designates her women as her 'noble girls':

How do you, women?

What, what, good cheer! Why, how now, Charmian?

My noble girls! Ah, women, women! Look,

Our lamp is spent, it's out! 
The choice of the word 'girl' here avoids the already over-determined term 'noblewomen', which designated aristocratic class status. Rather than indicating high social rank, 'noble girls' opens up the sense of the phrase, suggesting a nobility of behaviour and indicating Cleopatra's respect for her women. In addition to constructing the relationship between Cleopatra and her 'noble girls' as affectionate, Cleopatra's speech, with its insistent repetition of the word 'women', incorporates her servants into the royal 'we' that Cleopatra has used throughout the play. The presence of the plural 'our lamp' immediately following the repetition of 'women' blurs the distinction between the 'our' that Cleopatra would use as the ruler of Egypt and the 'our' that she would use to refer to herself and her serving women collectively.

In contrast, 'maid' was a term that described women in relationship to men. As a word that defined single women as servants or virgins (or both), 'maid' carried with it the social directive that all unmarried women should be virgins. If 'maid' was defined in opposition to 'wife', the word 'girl' was instead defined in opposition to 'woman', reorienting the maturation process. With 'girl', marriage was no longer the primary marker of the transition into adulthood. Unlike 'maid', with its connotations of virginity and service, 'girl' was available to designate female youth without always specifying sexual status or societal function. The differences between the two terms can be seen in Hester Pulter's midseventeenth-century poem 'Alithea's Pearl', which tells the story of how Alithea, or Truth, offered the speaker an 'Orient Pearl' if she parted 'with all [she] had' (lines 2-3). ${ }^{10}$ The exchange takes place when the speaker 'was A Girle' (line 1), and she gladly accepts and enters into a close relationship with the allegorical figure, who asks the child if she could love her. The speaker, 'seeing her soe fare transcend all other', assures the goddess that she would 'Gladly live and Die' with her and that their 'Celesstiall Love the true Loves knot did tie, / Reciprocally promiseing nere to depart' (lines 7, 9-10). As with Rosalind and Celia, this language of erotic female friendship also echoes the conventions of heterosexual love language, from the speaker pledging to exchange all her worldly goods to her promise never to be parted from the goddess. They even seal their pledge of love with a kiss: 'She took possession of my virgin Heart, / In earnest of her love shee gave a kiss' (lines 12-13). This utopic vision of girlish love is disrupted, however, when Alithea reads the book of fate and reveals to the speaker that she has a future as a wife and mother. The goddess sees that 'both Infant, Maid \& Wife / Would bee involv'd' and that the speaker will be 'fild with inward trouble' (lines 42-3). In contrast to that predicted future, which includes 'a tedious Pilgrimage' (line 46), the speaker's girlhood gets characterised as a time of innocence, 
rooted in an all-female community. In the rest of the poem, the speaker asks Alithea for a visit from Peace and Joy but is warned they rarely stay long; offered Patience and Hope in their stead, the speaker rejects them and learns the hard way when she wakes up to find that her visitors have fled. The speaker's yearning for Peace comes across as a desire to remain in a homoerotic safe space; when she asks that Alithea invite Peace 'To dwell with [them] in consummate delight' (line 26), the sexualised language of consummation suggests a connection between safety, joy (with Joy being figured as Peace's daughter) and homosocial spaces. The entrance in to heterosexuality, on the other hand, leads to pain and weariness that requires Patience to survive. As the poem concludes, Pulter declares, 'Thus have I livd a sad and weary life, / Thirteen a Mayd, and Thirtie three a Wife. / All I found true my Alithea did speak, / But yet (Aye mee) the bubble will not breake' (162-5). Having begun with a story about her girlhood with Alithea, she redefines herself as a maid and wife after she is forced to accept her heterosexual future.

'Girl', unlike 'maid', was a term that enabled early modern texts to acknowledge the roles of female characters in liminal social and sexual positions. In Romeo and Juliet, in the scene that immediately follows the implied consummation of Juliet's marriage to Romeo, Juliet is repeatedly called a 'girl'. Romeo's departure from the balcony at the beginning of the scene dramatises the consummation, making it clear that the two characters have spent the night together. The audience knows that Juliet is no longer a 'maid', though her parents do not. When Lady Capulet enters to see if her daughter is awake, her language accommodates Juliet's new liminal status, reflecting the parents' view of their daughter as their little 'girl' and the audience's knowledge that she has become a wife. Instead of calling her 'maid', which would linguistically undo the dramatic opening of the scene through which Juliet's new sexual status has been made known to the audience, Lady Capulet calls Juliet a 'girl' when consoling her over Tybalt's death, which Lady Capulet believes to be the cause of her daughter's distress: 'Well, girl, thou weep'st not so much for his death / As that the villain lives which slaughtered him' (3.5.77-8). As the conversation continues and Juliet equivocates about her feelings for Romeo, her mother once again calls her a 'girl' while attempting to cheer her up with news of Juliet's impending marriage to Paris: 'But now I'll tell thee joyful tidings, girl' (3.5.104). When Juliet's father enters later in the scene, he does the same (3.5.129). The play's language thereby avoids allowing the words of Juliet's parents to undermine the dramatic force of the scene's opening and prevents any potential audience confusion caused by the language of the characters. The language of girlhood provided a viable way to designate the place 
of female characters outside the traditional 'maid, wife, widow' schema. Juliet can be a 'girl' and still be sexually active.

In contrast to Act 3, Scene 5, Lady Capulet couches Juliet's status in terms of maidenhood the first time that she proposes that Juliet marry in Act 1 . Her claim that by her count she was a mother at Juliet's age involves the statement that Juliet is a 'maid' (1.3.75). In fact, prior to the consummation of Romeo and Juliet's marriage, the only character to call Juliet a 'girl' rather than a 'maid' is the Nurse, and she does so in the context of a series of affectionate (and diminutive) nicknames. Calling Juliet on behalf of Lady Capulet, the Nurse addresses her as 'lamb' and 'ladybird' before asking with exasperation, 'where is this girl?' (1.3.34). The Nurse's 'girling' of Juliet seems related to her acute awareness of Juliet's not-so-distant infancy. For the Nurse, however, Juliet's virginity is and always has been temporary, so it is not surprising that she views her charge as existing in a liminal sexual state. Immediately prior to calling Juliet a 'girl', the Nurse swears by her own 'maidenhead at twelve year old' (1.3.2). The Norton editors suggest that this is '[p]resumably the latest date that the Nurse could swear by her virginity', but of course it will also be the last date by which Juliet can swear by her virginity. ${ }^{11}$ Indeed, the subsequent bawdy tale of Juliet falling on her face and the Nurse's husband joking that it presages a time when she will fall backward in sexual union speaks to the way that young maidens in the play always already seem destined to stop being maids. Even in the opening scene, Samson and Gregory begin by talking about 'maids' as servants and then proceed to redefine the women of the house of Montague in sexual, rather than social, terms. After declaring that once he's fought with the Montague men he'll be 'civil with the maids' and 'cut off their heads', Samson makes the sexual pun explicit: 'Ay, the heads of the maids, or their maidenheads, take it in what sense thou wilt' (1.1.19-20, 22-3). Juliet invokes a similarly morbid understanding of her maidenhood when she learns of Romeo's banishment, fearing that as 'a maid', she will 'die maiden-widowed', lamenting that 'death, not Romeo' shall take her 'maidenhead' $(3.2 .135,137)$. Although 'maid' did not always have such negative connotations - Romeo calls Juliet a 'fair maid' as a term of affection (2.1.103) - its various meanings are over-determined compared to the flexibility of 'girl'.

As 'girl' became more dominant, however, it was eventually incorporated into a linear narrative of women's lives. The explosion of terms 
in English for 'girl' in the sixteenth century followed the developmental pattern for vernacular vocabularies that Juliet Fleming traces in her study of early monolingual English dictionaries, one that would result in 'girl' being carefully defined against the other terms in its semantic network and the predominant definition of 'girl' coming to be a female child. ${ }^{12}$ Using John E. Joseph's structural model for the two phases involved in the development of vernacular languages, Fleming argues that the sixteenth century in England was a time of elaboration in the early English lexicon aimed at correcting its 'inadequacy' and making it a suitable replacement for Latin as the official language of the state. In the seventeenth century, however, a restrictive phase of standardisation followed in which regulations were introduced to control what was perceived as an unruly and unconstrained elaborative process that needed rules to create standards. This process explains how girls became what we think of as girls today.

The lexical history of the term 'girl' bears out Fleming's analysis in a narrative that also corresponds to the linear narrative that Michel Foucault describes in The Order of Things, which provides a useful framework for understanding these diachronic changes. According to Foucault, the early modern world in the sixteenth century interpreted signs according to similitude, seeing correspondences between categories that created a sense of abundance and copia. By the seventeenth century, however, he locates a shift in the way of organising the world that interpreted words and things according to differences. Order is established, he argues, not by discovering resemblances, but by scrupulously categorising difference, a shift that leads to the eighteenth-century taxonomical impulse. ${ }^{13}$ As in Foucault's historical narrative, the story of 'girl' and its semantic network goes from similitude to difference, from interchangeable categories to mutually exclusive definitions. The innovations taking place in the vocabulary of female youth in the sixteenth century were in part the effect of a sixteenth- and early seventeenth-century lexicographical project. However, in the case of 'girl', I would argue that the general push to fashion the English language into a vernacular replacement for Latin worked in concert with an interconnected shift in cultural constructions of gender and youth.

The general changes taking place in the way that early modern society produced knowledge had particular effects on the way that early modern English speakers constructed gender differences in language, a shift that can be traced in early modern dictionaries. At the beginning of the sixteenth century and through most of the early modern period, what characterised the language of early modern female youth was multiplicity. The compilers of early English dictionaries were seeking to capture the 
wide-ranging vocabulary of early modern English, and their word lists acted as a kind of archive of the actual words being used by speakers and writers. One reason 'girl' would initially have been interchangeable with its synonyms was a function of the literary medium in which it appeared. Early modern dictionaries provided English alternatives for foreign words, not fixed lexical definitions of English ones. Dictionaries that provided explanations in English of a comprehensive list of English words did not yet exist; the only monolingual dictionaries in the sixteenth and early seventeenth centuries were 'hard word' dictionaries that excluded everyday words. With one or two exceptions, most of the dictionaries in which 'girl' appeared were foreign-language ones that translated between English and French, Latin, Italian or Spanish. ${ }^{14}$

This blurring of lexical boundaries was in keeping with early modern linguistic praxis. 'Maid', for example, was sometimes used to indicate female children, but it was less frequently used than 'wench' and often was left out of dictionary entries when the primary connotation of the foreign word was 'female child' rather than 'female virgin' or 'female servant'. Only the beginnings of a separation between the terms can be traced. Giovanni Torriano's Vocabulario Italiano e Inglese (1659) takes the entry for carósa from John Florio's A Worlde of Wordes, or Most Copious, Dictionarie in Italian and English (1598) and adapts it so that it gestures toward a differentiation between 'girls' and 'maids'. Where Florio defines carósa as 'a yoong maide, a lasse, a girle, a wench, a maiden seruant', ${ }^{15}$ Torriano deletes 'a yoong maide' and 'maiden seruant' and instead gives the entry as 'a wench, a lasse, a girle'. ${ }^{16}$ His removal of 'maid' may suggest a desire to de-emphasise service and virginity and play up the Italian word's connotations of female youth. The entrance of 'girl' into English and its increasing prominence can be seen, but its establishment as the dominant term for a female child happens gradually and, along the way, these texts present the terms as generally interchangeable. The link between service and virginity most likely reflects the requirement that apprentices be unmarried and the social custom that resulted in most girls going into some form of service. Most young women, even at the upper levels of society, would have been sent away from the parental home in their teens, in some cases as apprentices, but more often as domestic servants. ${ }^{17}$ Because of a statute from 1567 , unmarried women of the lower classes between the ages of fourteen and forty could be pressed into service, and even aristocratic young ladies, who would have been exempt from the statute, would most likely have been sent out to be ladies-in-waiting in other aristocratic households. ${ }^{18}$ As such, it makes sense for service, youth and singlehood to have been linked together both conceptually and linguistically. Ilana 
Krausman Ben-Amos rightly cautions against modern historians conflating dependency with immaturity such that we describe twenty-one-yearold apprentices as if they were socially and emotionally equal to children of twelve or thirteen; if masters were imagined to function as parental substitutes, the metaphor need not be understood to do away with all distinctions between subordinate social positions. ${ }^{19}$ Nevertheless, it is the case that the early modern vocabulary of youth did see affinities between the positions of servants (who typically entered service while relatively young) and children (who were by definition young).

The distinctions between English words sharpened, however, in the earliest monolingual dictionaries that focused on common English words, and differentiation brought with it the opportunity for lexicographers to be more explicit about the connotations involved in using the words 'girl' and 'maid'. In A New English Dictionary Shewing the Etymological Derivation of the English Tongue (1691), the word 'maid' was etymologically distinguished from 'girl' and explicitly linked to virginity: 'A Maid, from the AS. Maeyden, the Belg. Maeght, Maegho, or the Teut. Magh, idem, a Virgin. Hence the AS. Maden-hade, a Maidenhead, or Virginity.'20 'Girl', on the other hand, was a common enough word to require no explanation. Skipping the literal definition, the dictionary goes straight to describing gendered behaviour as the source of the word's meaning. The compiler explains its supposed etymology, claiming, 'Minshew draws it from the Lat. Garrula, because they are given to prating. It may also be drawn from the Ital. Givella, a weather-cock; which comes à Gyrando, from turning round; thereby denoting their inconstancy. ${ }^{21}$ The move to differentiate 'girl' from and within its semantic network was co-extensive with its association with negative aspects of femininity, a point to which I will return when I discuss John Palsgrave's 1530 French-English dictionary, which provides the earliest recorded use of the term 'girl' to mean a female child rather than a child of either sex. Although 'girls' might be expected to be 'maids', the possibility that they might be prating and inconstant calls into question the exchangeability of the two terms.

By the time that Samuel Johnson compiled his groundbreaking dictionary in the eighteenth century, 'girl' and its semantic network had undergone a transformation, and the word 'girl' had officially been established as the default term for a female child. With Johnson, we have a dictionary that defined both hard and common English words and that attempted to define words specifically and precisely. The vocabulary of girlhood was accordingly less profuse and more defined. A 'girl' in Johnson's dictionary was not a 'maid' or a 'damsel' or a 'lass' or a 'wench', but simply a 'young woman, or a female child'. ${ }^{22}$ 
No other alternatives were given. The principal definition of 'boy' was likewise relatively stripped down, being defined as 'a male child, not a girl'. ${ }^{23}$ Interestingly, Johnson defines boys by what they are not, namely girls; in contrast, girls are simply young women or female children, thus inverting the adult binary through which women are often defined as 'not men'. The implication is that girls are the standard against which categories of children are defined. ${ }^{24}$ The prominence of 'girl' within the eighteenth-century lexicon also appears clearly in Johnson's definitions of potential synonyms for young women. Although other alternatives are given, 'girl' is the first term in the definition for 'lass', which is 'A girl; a maid; a young woman: used now only of mean girls' ${ }^{25}$ Beginning with 'girl' as a definition, Johnson then defined the eighteenth-century 'lass' as a particular type of girl - one who was lower class. Johnson's combined entry for 'maid' and 'maiden' likewise did not explicitly connect maidenhood with youth. A 'maid/maiden' for Johnson was 'an unmarried woman, a virgin', as well as a 'female servant'. ${ }^{26}$ The association of 'maid' with female children remained only in Johnson's dictionary when 'maid' modified the term 'child' in a quotation from Leviticus under his third definition, where 'maid' indicated femaleness in general. 'Maid' was no longer automatically associated with children, but with sexual purity and, hence in the case of 'maidenhood', 'freedom from contamination'. ${ }^{27}$ The lexical effect of Johnson's dictionary was to pare down and precisely define the vocabulary of female youth.

The increased visibility of the word 'girl' was not merely a generic effect of the transition to monolingual dictionaries. Over the course of the sixteenth and seventeenth centuries, the term 'girl' appeared with increasing frequency and occupied an even more prominent role in a wide variety of genres, becoming more closely associated with female childhood along the way. Having examined the increasing prominence of 'girl' in early modern dictionaries, I now want to show that the establishment of 'girl' as the dominant term for a female child coincided with the incorporation of the category of the 'girl' into a linear model of the female life cycle. This incorporation, I suggest, made 'girl' less serviceable for describing female identities that fell outside prescriptive patriarchal roles because girlhood would become simply an earlier step in the progression that would lead inevitably to marriage.

At the beginning of the sixteenth century, the terms that were to become specific to female children were only just emerging. When 
writers wanted to distinguish between female children and male children, the most common method was to use the phrases 'woman child' and 'man child'. Designating the biological sex of infants was achieved predominantly through the addition of the qualifiers 'woman' and 'man', and the use of these adult terms, rather than terms that were specific to childhood, located sexual difference in the adult world. This particular formulation placed female children and adult women, as well as male children and adult men, into bifurcated sex-gender categories. On the one side were women and women children; on the other were men and men children. 'Boy' existed as a specialised term for male children as far back as the Middle Ages, but with no dominant corresponding term for female children, it was not yet frequently used when male and female children were being defined against each other. The differences between men children and women children were essentially future differences that would manifest in adulthood; the labels for them were markers of their future place in the adult sex-gender hierarchy.

As a number of scholars have argued, male and female children were relatively undifferentiated before the age of seven, when breeching ceremonies began the initiation of boys into masculine culture and separated them from their female caretakers. Although the extent of their separation varied with their class, breeching was a custom that appears to have taken place at all levels of society. Prior to this cultural production of sexual difference, the sex of a child was less socially marked. In fact, because children of both sexes were socially disadvantaged within early English power relations, they were all, like women in general, subordinated to adult men. That is not to say that all children were gendered female, but that all children, including boys who had been breeched, were subordinate to adult men. In relation to the word 'child', the word 'boy' functioned as what Roman Jakobson has called a marked term. According to Jakobson's structuralist linguistic theory, binaries normally employ marked and unmarked terms, where the default or naturalised term is 'unmarked' and the other term is 'marked' as different. ${ }^{28}$ The most obvious example of such a tendency is the use of 'man' as a universal term. 'Man' can indicate humanity in general or a male human being, whereas 'woman' is always particular, only referring to a female human being. In so far as words reveal a culture's underlying biases, Barrie Thorne and Nancy Henley have suggested that a study of modern English vocabulary reveals that 'the male is associated with the universal, the general, the subsuming; the female is more often excluded or is the special case'. ${ }^{29}$ This was already true in early modern English, although an interesting reversal of this tendency for female terms to be marked occurs with the term 'midwife'. Men who began practising mid- 
wifery were entering into a field perceived as female and were accordingly called man-midwives, the qualifier 'man' marking them as different from the usual practitioner. ${ }^{30}$

As in the case of midwives, the default sex of children was reversed. If 'child' was the universal term, 'boy' was the special term, functioning as a linguistic device that enabled male children to pass into a liminal stage between the female world of childhood and adult manhood (though boys were very carefully defined in opposition to men in order to police the bounds of masculinity). Although 'boy' had multiple synonyms, such as 'lad' and 'stripling', 'boy' was quickly established as the primary term for a male child while 'girl' was still emerging. Whatever the historical situation of actual girls and boys in early modern England, the important point to note in terms of language is that writers and speakers of early modern English did not define childhood as specifically male, nor does 'boy' become the default term for 'child'. In fact, when the umbrella term 'child' was gendered, it was gendered female, as in the well-known textual crux from The Winter's Tale. Having spotted the abandoned infant Perdita on the Bohemian seacoast, the Old Shepherd exclaims, 'Mercy on's, a bairn! A very pretty bairn. A boy or a child, I wonder?' (3.3.67-8), a statement to which I will return in Chapter 3.

The waning association of childhood with the feminine is reflected not in the development of 'boy' as a specialised term for a male child but in the development of specialised terms for female children. It reflected a growing sense of the need for language to mark more clearly the biological sex of female children, and 'girl' was only one of the English words for children in general that went from being gender neutral to gender specific during the period. 'Maid', which in Middle English could indicate a virgin of either sex or a female servant, was by the seventeenth century becoming increasingly gendered female. That early modern people were aware of this transition is evident from Sebastian's quip in Shakespeare's Twelfth Night that Olivia has 'been betrothed both to a maid and a man' (5.1.256). The 'maid/man' is Sebastian, who is playing with the ability of the word 'maid' to refer both to himself as a male virgin and to his twin sister Viola. Sebastian's wit depends upon the juxtaposition of both definitions, calling attention to the substitution of Sebastian for Viola. The humour depends upon the multiple meanings of 'maid', and modern readers often miss the joke because our own definition of maidenhood is so gender specific.

As 'girl' and 'boy' became the default terms for female and male children, childhood was increasingly represented as encompassing boyhood and girlhood, two separate kinds of childhood with different gender expectations. The earliest recorded use of 'girl' definitely to mean a 
female child rather than a child of either sex comes from John Palsgrave's Lesclarcissement de la langue francoyse (1530), which defines garçon, a boy, against garçe, a girl. That the earliest known source is a dictionary should not be surprising, since it is difficult outside of a definitional context to determine whether 'girl' was being used in a gender-specific context. In Middle English, as previously noted, a 'girl' could be either a male or female child, unless modified by the terms 'knave' or 'gay' to signal a male or female respectively. The unisex nature of the term can be ambiguous in some texts, but an example can be found in the B version of Piers Plowman when Dame Study boasts that she taught Plato and Aristotle and wrote the first 'Grammer for girles' (10.176). ${ }^{31}$ It is unlikely that the allegorical figure means that she wrote a grammar book for female children; if anything, she would be much more likely to be referring to male children, and as recorded by the Middle English Dictionary, the word 'childeryn' appears as a variant for 'girles' in several of the manuscripts. The date that 'girl' became gender specific has been up for debate, but most experts like Grzegorz Kleparski and Anne Curzan locate the transition somewhere after Chaucer and before Palsgrave. That is not to say that writers never referred to a female child as a 'girl' prior to 1530 , just that the gendering of the term remains ambiguous. As Curzan has argued, the unmodified use of 'girl' in Pearl (c. 1375-1450) does not set the word in opposition to 'boy', so we cannot know if it is female specific, and Chaucer's references to 'som gay gerl' in The Miller's Tale proves likewise unrevealing because the modifier 'gay' marks the term as female without telling us whether the term itself had become female. Curzan also suggests that the 'yonge gerles of the diocese' mentioned in Chaucer's General Prologue could easily refer to children of both sexes, and, indeed, although the Oxford English Dictionary lists Pearl as the earliest occurrence of 'girl' to mean a female child, it places the young girls of the diocese under definition 1, 'a child of either sex'. It is possible that a Middle English manuscript will be found in which 'girl' (as opposed to 'gay girl') will be set in opposition to 'boy', but until we can find an earlier source that pits 'girl' against another term, Palsgrave's dictionary stands as the earliest recorded use of the word to mean a female child, though it is worth noting that 'girl' as a designation for a specifically female child must already have been well established for it to make its way into Palsgrave's dictionary. ${ }^{32}$

Not only does 'girl' appear in Palsgrave's chart of substantives, the word 'girl' gets placed in opposition to 'boy' in his section explaining how to transform masculine words into feminine words by changing the endings, such as transforming garçon into garçe. Palsgrave was highly concerned with the gender of French nouns, an interest that led him to 
associate the gender of words with gendered behaviour. Under the entry for the verb 'bolden', for example, Palsgrave gave the French translation for the English sentence 'It is good to bolden a boye in his youth / and to acustome a gyrle to be shame faste' as 'Il fayt bon danimer, or dēhardyr vng garcon en sa ieunesse, et daccoustumer vne garce destre vergongneuse'. ${ }^{33}$ Palsgrave's interest in the gender of words had its ideological counterpart in the sayings that he chose to translate from French into English; he associated the grammatical gender differences between 'boy' and 'girl', or garçon and garçe, with gendered behaviour. Changing the ending of garçon and turning it into garçe required a parallel change in the way boys and girls were raised, or so Palsgrave's example suggested. By adding extra terms and by marking nouns as feminine and masculine, Palsgrave blurs the line between language and gender identity.

As 'girl' became more and more defined as the opposite of 'boy', rather than an ever-shifting signifier for multiple female roles, it was eventually incorporated into a linear narrative of women's lives. Women's lives began to be more widely represented in the seventeenth century as being divisible into discrete stages, just as attempts to draw sharper distinctions between the lexical terms for 'young female human beings' became more common. Unlike the 'Ages of Man', of which Jacques's speech in As You Like It is perhaps the best-known example, the 'Ages of Woman' prior to the mid to late seventeenth century was 'not a widespread cultural topos', in the words of Hanna Scolnicov. ${ }^{34}$ This lack in the literary record may well be attributable to the fact that women's life cycles were not conceived of as organised in such a clearly demarcated way. As I discussed in the introduction, female children were differentiated from adult women, but their progress into adulthood was imagined as continuous rather than marked by a break. The blurry, indeterminate line between female childhood and adulthood sharpened, however, as it became more common to imagine women's lives as also consisting of a set of mutually exclusive stages.

Whereas before mid-century 'girl', 'maid' and the other words in their semantic network were generally used interchangeably, by the end of the century attempts to categorise women's lives taxonomically became more widespread. This formulation of women's life cycles is most clearly articulated in John Amos Comenius's Orbis Sensualium Pictus (1659). The purpose of this emblem book was to help schoolboys learn Latin, and it consisted of emblems illustrating Latin poems and their English translations. Adding women to his representation of the 'seven ages', Comenius places figures illustrating each age on a set of ascending and descending stairs that correspond to the stages of growing up and growing old. To explain the picture, Comenius writes: 


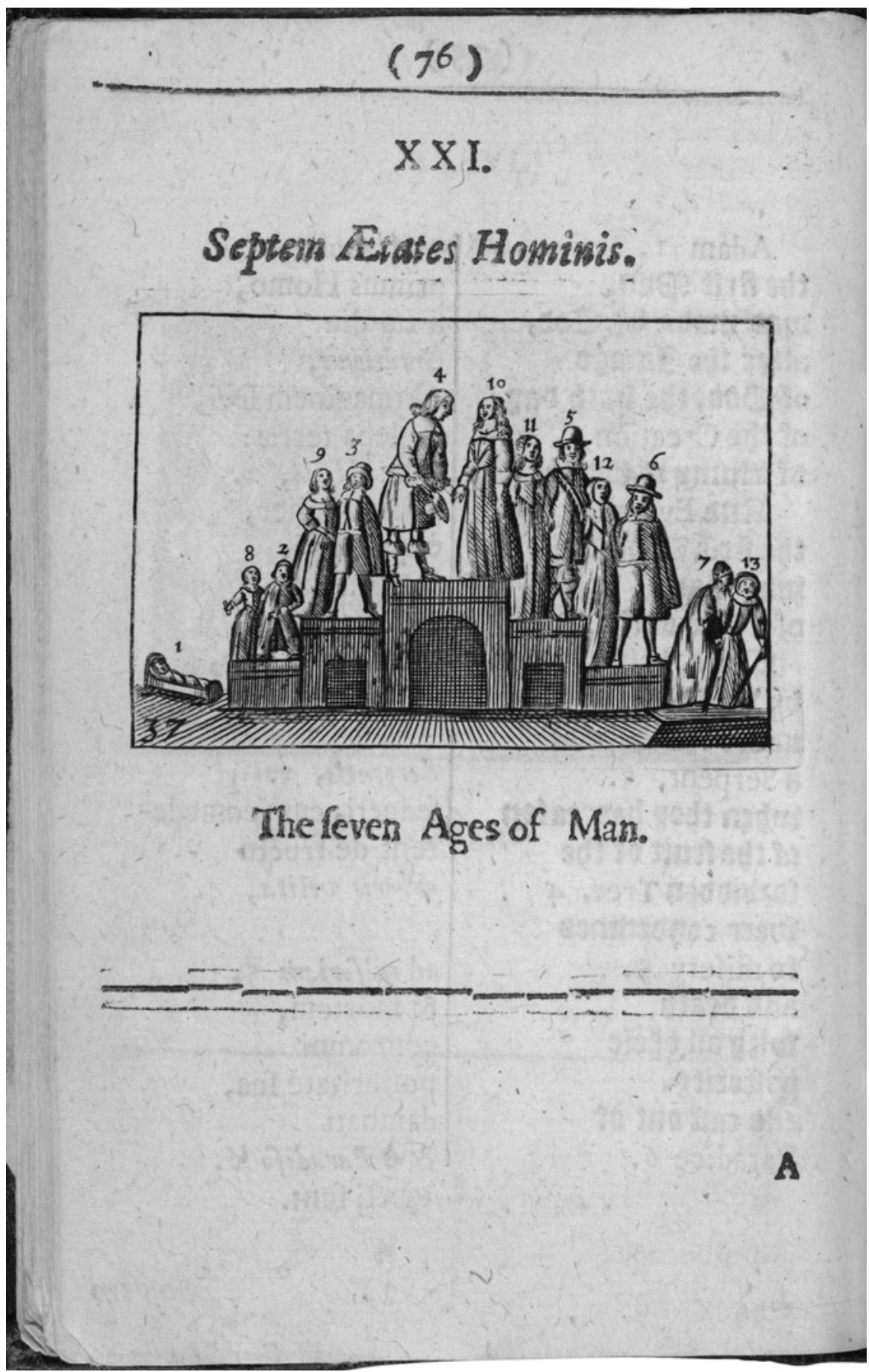

Illustration of the 'Seven Stages of Man', from John Amos Comenius's Orbis Sensualium Pictus (London, 1659). Courtesy of the Folger Shakespeare Library. 
A man is first an Infant, then a Boy, then a Youth, then a Young-man, then a Man, after that, an Elderly-man and at last, a decrepid old Man, So also in the other Sex, there are, a Girle, A Damosel, A Maid, A Woman, an Elderly Woman, and a decrepid old Woman. ${ }^{35}$

Unlike the early foreign-language dictionaries, a 'girl' in this formulation is neither a 'damsel' nor a 'maid' but as distinct from them as from 'boy'. Infancy, interestingly enough, is the only life stage during which no gender distinction is present in the woodcut, illustrated as it is by a single swaddled child, but after the uniquely gendered time of infancy (to which I will return in Chapter 3), life consists of boyhood and girlhood as separate masculine and feminine stages.

At stake in the emergence of these multiple terms were competing definitions of female youth. What it meant to be a 'girl' or 'maid' or 'wench' or 'damsel' was very much up in the air, and although these terms were not necessarily defined against each other, they did have patterns of usage that reflected the speaker's assumptions about female children and adult women. Word choice could define female youth by age, sexual and/or marital status, behaviour, class or any combination of these. Children as a group were closely associated with servants as subordinated groups, so it is not surprising that many of the words for children also doubled as words for adult servants. In that sense, late medieval and early modern constructions of childhood often defined it more as a power relation than as a time of life. As childhood became more associated with age and less with service, however, the words that had once doubled for servants began to be separated out and no longer applied to children, as did words that explicitly defined female children by their sexual status (whether positively or negatively).

'Wench' is a perfect example of a term with connotations that eventually led speakers to stop using it as a synonym for 'child'. After 'wench' became a word for female children and lower-class women, it metamorphosed from a 'socially pejorative' term (i.e. female servant) into a 'morally pejorative' term (i.e. wanton woman). ${ }^{36}$ As a linguistic category, 'wench' in early modern English was exceptionally polysemous, defined as it was by age, class, social function and behaviour. The eventual elimination of the term 'wench' as a label for female children can most likely be attributed to the conversion of its lower-class associations into associations with wanton behaviour, and its earlier metamorphosis into a general term for female children was indicative of the association between being female and being socially subordinate. 'Wench' came to be a derogatory term in a way that 'girl' functioned much less frequently. When Mercutio says Romeo has been 'stabbed with a white wench's black eye', he clearly does not mean to be complimentary 
(2.3.12-13). The pejoration of 'wench' was part of a general semantic derogation that Muriel R. Schulz has uncovered in the English language. 'Again and again', she writes, 'one finds that a perfectly innocent term designating a girl or a woman may begin with totally neutral or even positive connotations, but that gradually it acquires negative implications, at first perhaps only slightly disparaging, but after a period of time becoming abusive and ending in a sexual slur. ${ }^{37}$ Other than its gender associations, it is not entirely clear why 'wench' underwent this process of semantic derogation at this particular moment, but as it became more negative, it was applied less frequently to children.

If 'wench' was a term initially applied to children of all social classes that later came to designate only lower-class women, 'damsel' was an aristocratic term that gradually came to be applied to women more generally. Derived from the diminutive of dame, the female equivalent of dominus or lord, 'damsel' referred predominantly to aristocratic women in later Middle English. 'Damsel' is anomalous, however, in that it was used in the twelfth century as a term for a serving woman, overlapping with the Middle English words 'maid', 'maiden' and 'wench'. Why a word etymologically linked to aristocratic titles should have begun as a designation for a servant is a mystery, but it may be related to the previously mentioned custom of sending children of the gentry and the aristocracy into service in other wealthy households. 'Damsel' did not acquire its aristocratic associations until the fourteenth century, and then it did so through its centrality to Romance, which contributed to making it a prominent word in Middle English. ${ }^{38}$ By the late sixteenth century, however, 'damsel' was no longer a term of everyday parlance but was instead specific to poetry and Romance.

The reason that 'damsel' was somewhat peripheral in the early modern vocabulary of female youth was that 'damsel' gradually acquired an archaic and poetical sense. It is not surprising, for example, that 'damsel' would come out of the mouth of the unctuous Neatfoot in the opening of The Roaring Girl. Greeting Mary Fitzallard, Neatfoot says, 'The young gentleman, our young master, Sir Alexander's son - it is into his ears, sweet damsel, emblem of fragility, you desire to have a message transported, or to be transcendent?' (1.1.1-4). ${ }^{39}$ Neatfoot's obsequious language links 'sweet damsel' with the over-the-top 'emblem of fragility', and his elaborate and tortured sentence structure is as laboured as his addressing of Mary as 'your chastity'. Since Neatfoot believes that Mary is involved in an illicit affair with his master, his politesse is about as sincere as his polite addressing of Mary as 'damsel'. That said, 'damsel' was not always an insincere form of respectful address. 'Damsel' also appeared a great deal in poetry; writers drawing 
on a Middle English poetic tradition often used 'damsel' sincerely. As a result, 'damsels', rather than 'girls', dominate Edmund Spenser's The Fairie Queene, which is both an aristocratic poem and a consciously archaic one.

That said, although 'damsel' had a fairly rigid definition, it could, when co-opted in the service of different genres, carry slightly different connotations. John Harington's 'The Author to a Daughter of nine yeere old' (1618) is an epigram where the aristocratic associations disappear when the term gets exported from Romance. Harington transplants 'damsels' from the world of fairies and knights to the household, where daughters are asking fathers for costly items. He writes:

Though pride in Damsels is a hatefull vice,

Yet could I like a Noble-minded Girle,

That would demand me things of costly price,

Rich Veluet gownes, pendents, and chaines of Pearle

Carknets of Aggats, cut with rare deuice,

Not that hereby she should my minde entice

To buy such things against both wit and profit,

But I like well she should be worthy of it. ${ }^{40}$

In this poem, Harington distinguishes between 'Damsels', who should be humble, and 'Noble-minded' girls, who are worthy of spoiling with riches. Given that the daughter is nine years old, Harington may be differentiating between 'damsels', mature young women who should have learned humility and who are sexually mature, and 'girls', who are primarily defined by their status as daughters and who, in that capacity, usurp the nobility and class associations of damsels in the Romance genre.

In the end, 'girl' would win out over terms like 'maid' and 'damsel' and become the dominant counterpart for 'boy'. Tracing the evolution of terms for female children in midwifery manuals provides a striking illustration of this process because the medical concern over how to guess the sex of an unborn child provides moments when female and male infants were set in opposition to each other in similar texts over the course of a century. In contrast, the sex of actual children in parish record books was not always noted. Moreover, because of the emphasis on biological processes in medical discourse, it is possible to know the relative ages of the 'girls' discussed in midwifery manuals, whereas the age of children mentioned in other discourses are frequently indeterminate.

In arguably the earliest midwifery manual published in England, Richard Jonas's translation of Eucharius Rösslin's The Byrth of Mankynde (1540), male and female infants, as well as older children, are referred 
to by the terms 'man child' and 'woman child'. ${ }^{41}$ In fact, they are even occasionally called simply 'man' and 'woman', as when Jonas writes:

But if ye be desirous to knowe whether the conception be man or woman: then lete a droppe of her [the mother's] mylke or twayne be mylken on a smothe glass / or a bryght knife / other elles on the nayle of one of her fingers / and yf the mylke flewe and spredde abrode vpon it / by and by then is it a woman chylde: but yf the droppe of mylke continue and stande styll vppon that / the which it is milked on / then is it sygne of a man chylde. ${ }^{42}$

When Thomas Raynald (Jonas's publisher) reprinted Jonas's translation in 1552, he did use the word 'boy', but not as a term for a male infant. The word 'boy' occurs instead at a moment when boys were not being placed in contradistinction to female children. Replacing Jonas's dedication to Queen Katherine with 'A prologue to the women readers', Raynald sought to assuage the fear that 'every boye and knaue had of these Bokes, reading them as openly as the tales of Robin hood'. ${ }^{43}$ The boys who might abuse The Womans Book are much older than the men children referenced in the text of the manual itself. Male infants in this text remain 'men children'.

'Man child' and 'woman child' would persist into the early seventeenth century, but translators also started to mix in other terms. The competition that 'girl' faced as the replacement for 'woman child' can be seen in the translation of Jacques Guillemeau's 1612 midwifery manual, Child-birth, or The Happy Deliverie of Women. Guillemeau's translator consistently uses the word 'wench' in lieu of 'girl', titling the second chapter 'The signes whereby to know whether a woman be with child of a boy or a wench' ${ }^{44}$ Female infants throughout this section are 'wenches', and male children are consistently 'boys'. That this boy/ wench dichotomy was not just a quirk of Guillemeau's is evident from Charmian's question to the soothsayer in Antony and Cleopatra, when she asks, 'Prithee, how many boys and wenches must I have' (1.2.32). Most of the time Guillemeau's translator simply calls the child 'the child', with no indication of biological sex, but when he wants to be specific, 'wench' is his primary term, and he employs it exclusively as a gendered term that denotes infancy.

Although 'wench' had its place in the lexicon, 'girl' would prove to be far more popular in the mid-seventeenth century. The English translation of The Workes of that famous Chirurgion Ambroise Parey uses both formulations for sexual difference, alternating 'man child' with 'boy' and 'woman child' with 'girl'. Claiming that the quantity of 'seed' taken from each parent determines the sex of the child, Paré writes that if in the mixture of seed 
mans seed for quality and quantity exceed the womans, it will be a man child [not] a woman child, although that in either of the kindes, there is both the mans and womans seeds, as you may see from the experience of those men who by their first wives have had boyes onely and by their second wives had girles onely. ${ }^{45}$

By making these two sets of terms synonymous, Paré illustrates the interchangeability that would enable the gradual substitution of 'girl' and 'boy' for 'woman child' and 'man child'. By the time Nicholas Culpeper and Jane Sharp wrote their midwifery manuals in English in 1651 and 1671, 'woman child' and 'man child' had disappeared completely, and both relied on 'boy' and 'girl' to designate sexual differences between infants at birth. It is worth noting, however, that 'boy' never became an unmarked term for children, and that when 'boy' and 'girl' appeared as a pair, they were rarely hierarchical. When Cleopatra laments 'Young boys and girls / Are now level with men' (4.16.67-8), she figures them as occupying the same level in the social hierarchy. Both are clearly perceived as being of a lower status than men, but girls are no lower than boys. Likewise, when Paulina criticises Leontes in The Winter's Tale, she describes his jealousy as 'Fancies too weak for boys, too green and idle / For girls of nine' (3.2.179-80). Using children of both sexes as markers of immaturity and unmanliness, Paulina implies that Leontes's behaviour is below the level that would be expected of children of either sex. 'Boy' and 'girl' did not have the same hierarchical relationship as 'man' and woman' because the two terms indicated mutual positions of disempowerment.

As 'girl' became a more prominent term, however, it ceased to be so easily interchangeable with 'maid', and consequently it came to be used more often to indicate the youth of a female human being rather than her liminal gender position. In the midwifery manuals of the seventeenth century, 'girls' came to be described as younger versions of 'maids', a categorical distinction that becomes apparent in Jane Sharp's The Midwives Book. Although she does not explicitly define 'girl', Sharp uses the term solely to refer to female infants; she likewise uses 'maid' solely to refer to sexually mature but not yet sexually active young women. When discussing the production of biological sex in the womb, Sharp consistently describes the engendering of 'boys' and 'girls'. She explains, for example, that 'it is generally maintained, that Boyes are begotten from the right stone, but Girles with the left'. ${ }^{46}$ In contrast, Sharp consistently categorises young women who have entered adolescence as 'maids'. When describing the onset and bodily effects of menstruation, Sharp describes the phenomenon as happening to 'maids'. 'Generally', she writes: 
maids have their terms at fourteen years old, and they cease at about fifty years, for they want heat and cannot breed much good blood nor expel what is too much; yet those that are weak sometimes have no courses till eighteen or twenty, some that are strong have them till almost sixty years old, fullness of blood and plenty of nutriment in diet brings them down sometimes at twelve years old. ${ }^{47}$

In differentiating the maturing with the mature, Sharp defines 'maids' against 'women', and the linguistic distinction reflects what Sharp describes as a bodily difference. According to Sharp, 'In those women that are married, [the labia] lye lower and smoother than in maids; when maids are ripe they are full of hair that grows upon them, but they are more curled in women than the hair of Maids. ${ }^{38}$ Although not explicitly set out as defining categories, Sharp's diction represents women's life cycles as progressing from the category 'girl' to 'maid' to 'woman', a move that differentiates the female life cycle by age and bodily development but which also subsumes girlhood into a linear narrative. Instead of providing an alternative for 'maid' that breaks the bounds of socially prescribed roles for women, 'girl' in this formulation is merely an earlier stage on the way to becoming a 'maid'.

III

Thomas Heywood's The Fair Maid of the West, or a Girl Worth Gold, Parts I and II (c. 1600-3 and 1630) powerfully dramatises the transition from copia to difference in the vocabulary of female youth that I have been describing. Having explored the general shift that took place, I want to use his plays to demonstrate the larger implications of these lexical changes. The result of defining girlhood first and foremost as a time of life was to make the category of the 'girl' less subversive and less threatening to gender hierarchies. The transformation that takes place in the language used to describe Heywood's heroine illustrates the way that the establishment of 'girl' as a dominant term for a female child came at the price of its ability to open up subversive female roles.

Over the course of the play, the title character Bess Bridges plays many roles, from an apprenticed drawer in Plymouth to a tavern owner in Foy to a cross-dressed sailor to a fine lady in Italy. At the age of almost seventeen, Bess is a 'maid' - a young and virtuous virgin - but she is also a 'wench', a 'sweet lass', a 'tanner's daughter', a 'she-drawer' and, above all, a 'girl worth gold'. Significantly, over the course of the two plays in which she appears, Bess is designated by all manner of terms with a diversity that reflects the rich and varied vocabulary of female 
youth in early modern English. When the first part begins, Bess is an apprentice in Plymouth; when the second part ends, she is a wife who has travelled from England to Spain to Africa and back to Italy. Written almost thirty years apart, the two parts of Fair Maid provide an illustration of the complex and changing ways that 'girl' and its related terms were used in early modern English. In the first part, her fellow characters designate her with a multiplicity of terms regardless of her shifting clothing, class, marital status and geographical location. In the second part, Bess is still a 'girl worth gold', even after her marriage and sexual initiation, but the characters no longer speak with the same fluidity of language. Bess is almost exclusively called a 'maid' prior to her marriage and almost exclusively a 'lady' afterwards. This divergence of the second part of Heywood's play not only indicates that Bess has changed her class status, but also marks an historical difference between the way sixteenth- and seventeenth-century language constructed and classified gender differences.

What makes The Fair Maid of the West so useful for investigating historical change is that the two parts share a common author, yet were composed at different moments in English history. Because of the Elizabethan tenor of Part I, critics generally fix its composition date between 1596 and 1603, a time when Heywood was writing for and acting with the Earl of Worcester's Men, a group that performed at public theatres such as the Rose, the Curtain and later the Red Bull. Heywood has long been recognised as a dramatist whose plays reflected the lives and values of the middling class, and the first part of Fair Maid was written for the diverse audience of the late Elizabethan public stage. Although records of a performance of Part I do not exist, the printed edition of both parts in 1631 appeared after a Christmas performance at Hampton Court for Charles I and Henrietta Maria. In contrast to Part I, Part II therefore was addressed to a more aristocratic audience. The historical distance between the two plays and the different audiences provide the opportunity to trace historical changes and class differences. Those changes, I suggest, were responsible for the significant transformation in the representation of Bess Bridges. She goes from being a swashbuckling, cross-dressing entrepreneur to being a damsel in distress.

Initially, scholars tended to focus on Part I of Fair Maid, preferring the gender-bending heroine of Heywood's earlier writing. Feminist critics have understandably found work on Bess to complement their research on dramatic figures like Moll Frith in The Roaring Girl and have paired her with cross-dressing female characters such as Shakespeare's Viola and Rosalind, as well as Clara from Love's Cure. ${ }^{49}$ Charles Crupi, Barbara Sebek and Claire Jowitt have recently provided analyses of the 
two plays together, exploring the radical changes that take place in Bess Bridges's personality and the social and racial issues raised by Bess's interactions with the King and Queen of Fez. Sebek focuses on economic factors and global trade with North Africa, while Crupi and Jowitt both explore factors in the Caroline court that would have affected the representations of race and queenship in the 1630s. ${ }^{50}$ Informed by their interpretations of the political differences between these historical moments, my reading of the two plays focuses on the historical changes in the discourse of girlhood that mediated Heywood's composition of Bess Bridges. The language that was available for the public stage at the turn of the century was different from the language that was available for the Caroline court in 1630, and it made a significant difference to the representation of her gender, class and racial identity.

Heywood was a writer who drew frequently from popular tradition, and as such the language with which his characters describe Bess in Part I reflected a popular vocabulary. Drawing on the ballad tradition, Heywood clearly tapped into the legends of Long Meg and Mary Ambree, two cross-dressing, fighting heroines who appeared frequently in chapbooks and ballads from the period and were popular reference points in plays when describing women engaged in masculine pursuits. ${ }^{51}$ In Part I, Heywood introduces Bess as a 'she-drawer', a tapstress in a tavern in Plymouth, where forces have been assembling for England's campaign against Spain. In the midst of these foreign enterprises, Bess is a domestic paragon of virtue and beauty, the daughter of a trade-fallen tanner who has been sent into service because of her family's economic difficulties. Bess is, as she proclaims herself, 'a pattern to all maids hereafter / Of constancy in love' (3.4.93-4), a key declaration that undergoes a telling metamorphosis in Part II. Although initially unable to marry her lover Spencer because of her lower-class status, Bess remains chaste and faithful, even after Spencer has had to flee Plymouth and has been (falsely) reported to have been killed in the war. She even disguises herself in men's garments and sets out to recover his body so that he can be reburied in England. As an adventurer, Bess patterns herself on the cross-dressing heroines in ballads, chapbooks and other popular literature. She does, as she says she will, do all that she has heard 'discours'd / Of Mary Ambree or Westminster's Long Meg' (2.3.12-13). The other characters may at times compare her to Queen Elizabeth, but Bess has more in common with those ballad heroines than with the virgin queen. That is to say, as Jean E. Howard has argued, that 'Bess is not simply a screen for Elizabeth', but is instead a repurposing of monarchical ideology to bring it in line with a form of English nationalism that related itself to the land of England as a geographical and regional entity, one 
that, as I will discuss shortly, also took on a racial valence. ${ }^{52}$ Bess's association with the virgin queen in Part 1 works to refashion those aristocratic symbols and ideologies with 'the values of another social class'. ${ }^{53}$

Over the course of Bess's adventures, her fellow characters name and rename her with the language of girlhood, a language intimately connected to her class status. The first part of Fair Maid is lighter and less moralistic than the second half, either because of the historical distance between the plays or because of the different audiences. By the second half, Bess's origins in the working classes have ceased to be acknowledged in the language, whereas in the first part, her lower-class status is of paramount concern and is reflected in the terms used to describe her. In Plymouth, where Bess is a drawer of wine, she is frequently called a 'wench'. Indeed, she is introduced by the First and Second Captains as 'the best wench' from the tavern with 'the best wine' (1.1.18-19). The Second Captain then refers to Bess as 'a sweet lass', one who is 'wondrous modest', 'affable' and 'not proud'. She is, in effect, an oddity for a tavern woman because she is chaste, and an oddity for a chaste maid because she is affable. As Spencer acknowledges, 'She'll laugh, confer, keep company, discourse, / And something more, kiss; but beyond that compass / She no way can be drawn' (1.2.60-3).

Much of the play's action in Part I stems from Bess's need to teach those around her how to name her, or at least how to understand the various names that can be applied to her. By refusing to be Spencer's or anyone else's 'bawd', Bess defies neat categorisation. Her lower-class status separates her from being eligible to be Spencer's wife, and yet her chastity prevents her from falling into the category 'whore' - the derogatory status to which the 'maid, wife, widow' triad tries to relegate women who do not fall into its definitional categories. Faced with Bess's singularity, Spencer invites Bess to join him for drinks by saying, 'Gramercy, girl, come sit' (1.2.65). But there is no stability in Spencer's nicknames for Bess. No sooner has he called her 'girl' than he calls her 'wench' (1.2.86), a familiar term compatible with her class status.

Though her virtue is never truly imperilled, at stake is others' perception of her virtue, and Bess has to convince one man after another that as a single woman she is not necessarily a whore, a drudge or a strumpet. It is precisely an argument over what to call Bess that leads to Spencer's ill-fated quarrel with his fellow gentleman Carrol. Entering the room where Spencer and Goodlack sit drinking with Bess in attendance, Carrol objects to the presence of a mere 'she-drawer' and calls her no more than what she is, a 'tapstress'. However, because Bess's occupation automatically evokes illicit sexual connotations, Spencer takes offence at Carrol's language. Defending Bess's honour against Carrol's accusation 
that she is a 'drudge' and a 'housewife', Spencer slays Bess's detractor and sets off the play's narrative action. Spencer flees and makes Bess the mistress of his tavern in Foy while he departs for the Azores.

That language is not merely reflective but also potentially constitutive of Bess's identity can be seen in her initial encounters with Roughman, another character struggling to classify Bess and being thwarted in his attempts to fit her into fixed categories. When Spencer leaves Bess the tavern named the Windmill, Bess turns it into the most popular and successful tavern in Foy. She rises in economic and class status in Spencer's absence, not through marriage, but through her own financial savvy. Having achieved economic independence, Bess becomes an unmarried female of independent means, and as such she puzzles Roughman. He openly addresses his linguistic dilemma, brazenly declaring his right to control Bess and her business: 'I tell thee, maid, wife, or whate'er thou beest, / No man shall enter here but by my leave. / Come, let's be more familiar' (2.1.72-3). Portraying Bess as not fitting into the categories 'maid' or 'wife', Roughman insinuates that Bess occupies an unnamable position, a confused place that he signifies with the phrase 'whate'er thou beest'. If not a 'maid' or 'wife', Bess occupies a sexually ambiguous position, and Roughman assumes that this gives him the right to make her 'more familiar'. By implying that Bess is a 'whore', he hopes to make her into one. The conscious invocation of the 'maid, wife, widow' paradigm acts as an attempt to fix the definition of female youth within a marital narrative, but Roughman's continued confusion over how to designate Bess reflects the way that these categories broke down in the face of female roles outside of this prescriptive paradigm. Over the course of a short section of Act 2, Scene 1, Roughman calls Bess 'lady', 'minion', 'wench' and 'my good girl', changing words every time he addresses her by anything other than her name $(2.1 .66,70,94,103)$. Both his language and his behaviour indicate the way that Bess slips between names and defies a complete association between her and a single category. As she does throughout the play, Bess must teach Roughman that being young and unmarried makes her a 'girl', a 'wench', a 'lass' and a 'maid', but not a 'whore'.

Bess successfully re-educates Roughman by countering his words with actions. She dresses in men's clothing and challenges the braggart to a duel in the supposed persona of her brother. Unlike Shakespeare's Viola, who wants at all costs to avoid fighting with Sir Andrew Aguecheek in Twelfth Night, or Rosalind, who faints at the sight of Orlando's blood, Bess succeeds at her male impersonation. She exposes Roughman as anything but rough, proving him to be too cowardly to fight her. $\mathrm{He}$ neither retaliates when she physically strikes him nor responds to her 
verbal accusation that he is 'a villain' and 'a coward' (2.3.51). Instead, she forces him to untie her shoe, untruss the point of her hose, and lie on the ground while she strides over him, stomping on him in the process. Instead of defending his honour, Roughman claims he has taken an oath not to fight that day and agrees to do 'anything' to avoid fighting (2.3.73). But with no witnesses to his humiliation, Roughman remains unconverted, and he immediately returns to his swaggering ways, verbally abusing Bess's servants, striking her apprentice Clem, and attempting to kick her kitchenmaid. When Bess upbraids him, she calls him out on his bullying of weaker individuals. 'I do not think that thou dar'st strike a man,' she says, 'That swagger'st thus o'er women' (3.1.71-2). In response, Roughman dishonestly renarrates the encounter of the morning as if he had seriously injured the disguised Bess, rather than refused to fight her. Bess once again calls him out on his lie and reveals that she played the role of the male youth who struck and then trod upon Roughman. It is this revelation that finally brings about a radical reformation of the braggart.

Roughman's conversion depends upon Bess's convertibility from maid to man to woman, thus depicting her ability to shift back and forth between gender identities as having a positive transformative effect on those around her. Whereas Roughman's initial humiliation has taken place in a quasi-private space, Bess threatens the further indignity of public violence on the streets if Roughman does not change his ways. Compelling Roughman to make a vow of redemption, Bess warns him, 'Thou shalt redeem this scorn thou hast incurr'd, / Or in this woman shape I'll cudgel thee / And beat thee through the streets. / As I am Bess, I'll do't' (3.2.123-5). Having first beaten Roughman in the shape of a man, Bess threatens to beat him in the 'shape' of a 'woman', making visual Roughman's emasculation and the cowardice that underlies his tyrannising over servants and women. Bess's speech lays claim to womanliness in a way that calls attention to its mutability and sets up her continued cross-dressing in the play. In her earlier objections to Roughman's behaviour, she has already called attention to her shapeshifting abilities, declaring that she 'will have no man touch' her servants but herself (3.1.52). For all the anxiety of the other characters, Bess's dialogue in Part I expresses a level of comfort with moving between identities. When Bess takes to sea, for example, she declares that she has rich apparel for 'man or woman as occasion serves' (4.2.88). What defines Bess in Part $I$ is a willingness to adapt herself, to play the role necessary to serve the occasion. She also reinforces social codes of masculinity in the process, paradoxically insisting that Roughman overcome his cowardly behaviour while laying claim to her own right to perform 
masculine actions. In addition to being a 'maid' and a 'girl', Bess can also play a 'man' because she challenges gender boundaries more generally.

What Bess insists upon is her right to define and redefine herself. Together with Spencer's friend Captain Goodlack and her apprentice Clem, Bess and Roughman will go on to wield swords side by side against Spanish pirates on the high seas. When Bess hears the false news that Spencer has been killed in Spain, she commissions the building of a ship and sets sail to recover the body of her beloved. As it turns out, because Fair Maid is a comedy, the Spencer killed in Spain is a different Spencer altogether, but it sets up a global journey that reunites the lovers in Fez, Morocco, where Bess must teach not only another character, but another culture, the difference between girls, women and whores. The passage that best encapsulates the sexual implications of the exchangeability of 'whore' for 'girl' is the one in which Mullisheg instructs Bashaw Alcade on the construction of his alkedavy. 'Find us concubines,' he commands:

The fairest Christian damsels you can hire

Or buy for gold, the loveliest of Moors

We can command, and Negroes everywhere.

Italians, French, and Dutch, choice Turkish girls

Must fill our Alkedavy, the great palace

Where Mullisheg now deigns to keep his court.

In this speech, Mullisheg makes plans for an international harem that includes multiple ethnicities of women, all of which, like the terms 'damsel' and 'girl', are relatively interchangeable. The inhabitants of his alkedavy make literal the play's metaphoric title of 'a girl worth gold' by describing these girls as procurable with gold. Having not yet met an English woman, Mullisheg does not list English girls or damsels among his desired mistresses, but the appearance of Bess in his court leads to the desired addition of an English girl to Mullisheg's long list of mistresses. Bess, however, disrupts the exchangeability of women through her position as a matchless paragon of beauty. Up until this point, Bess has exhibited what Howard calls 'the almost miraculous power of the virgin woman to make flawed gentlemen into exemplary servants of the Protestant state'. ${ }^{54}$ Bess's own mutability has the power to counteract the potential fragmentation of English national allegiances along class lines, and her arrival in Fez works to export that ability to other races and nationalities. In the first part of Fair Maid, Bess's virtue is sufficient in itself to ward off the sexual advances of men, and simply witnessing her valour and loyalty to Spencer converts Mullisheg and leads him to 
respect Bess's chastity and England's honour, at least until the opening of Part II.

By the end of Part I, 'a girl worth gold' cannot be bought for money because she is above exchange. Bess's role is to teach Mullisheg and the other men in the play that 'girls' are not interchangeable with 'whores' and, indeed, that 'girls' are simply not interchangeable. At the end of Part I, Mullisheg echoes the chorus's earlier praise of Bess and declares:

Come, beauteous maid, we'll see thee crown'd a bride.

At all our pompous banquets these shall wait.

Thy followers and thy servants press with gold,

And the mean'st that to thy train belongs

But shall approve our bounty. Lead in state,

And wheresoe'er thy fame shall be enroll'd,

The world report thou art a girl worth gold.

The passage begins with Mullisheg invoking the 'maid, wife, widow' paradigm, promising to see Bess transformed from a maid into a bride and wife, but by the end of the passage he inserts a new term that disrupts the relegation of Bess into any of these roles. Instead of being remembered as a wife, Bess will be remembered as a 'girl worth gold', an adventure heroine who exceeds the social positions of the 'maid, wife, widow' schema. She may be a wife, but she will also be a 'girl'.

Mullisheg's prophecy that Bess shall be reported as a 'girl worth gold' was fulfilled in Bess's literary afterlife. She was remembered, not predominantly as a 'fair maid', but as the 'girl worth gold'. When first entered into the Stationers' Register on 16 June 1631, Fair Maid was listed as a 'Comedy Called the fayre mayde of the west: Ist and $2^{\mathrm{d}}$ pte'. ${ }^{55}$ The trope of the 'fair maid' was popular, and several other plays featuring 'fair maids' as their title characters appeared during the seventeenth century, including Heywood's own Fair Maid of the Exchange (1607) and John Fletcher's Fair Maid of the Inn (c. 1625-6). In each case, the 'maid' in question begins the play in a position of lower social status than she ends it. Bess is, however, much stronger and more independent than her fellow fair maids, and she was distinguished from them by being referred to in literary allusions as the 'girl worth gold'. It was predominantly as a 'girl worth gold' that Bess lived on in contemporary memory. When $\mathrm{T}$. B. refers to Bess Bridges in the prologue to The Country Girl, Bess is not a 'fair maid' but 'the girl worth gold'. ${ }^{56}$ In the long run, alliteration seems to have triumphed over the earlier connection with the 'Fair Maid' genre of plays because by the time a Restoration adaptation of Heywood's play was entered into the Stationers' Register 
on 5 April 1660, the order of Heywood's title had been reversed into 'a booke called A Girle worth Gold, or the famous History of the faire Maid of the West'. W. W. Gregg speculates that this book may well be John Dauncey's The English Lovers, or a Girl Worth Gold, published in 1662 , a prose text that dispensed with the 'fair maid' section of the title altogether. ${ }^{57}$ So popular was Bess Bridges that Heywood's play seems to have been revived that same year on the stage at the King's Arms in Norwich, where Edward Browne paid sixteen shillings to see the 'Girl worth Gold' and recorded the fact in his 'Memorandum Book'. ${ }^{58}$

Yet in Part II Bess is only called a 'girl' one time. By the time Heywood writes his sequel in 1630, Bess has become almost exclusively a 'maid' in the first three acts and a 'lady' in the last two, a linguistic shift that reflects the play's heightened concern over Bess's chastity. Although Bess's chastity is important in Part I, her virtue is equally demonstrated by her talent at running a successful tavern, her generosity to the community, her good humour towards even those people who behave with disrespect towards her, and her bravery in going to sea and fighting pirates. By Part II, her virtue has become synonymous with her chastity, and she is in danger of ravishment first by Mullisheg, then by bandits on the coast of Italy, and finally by the Duke of Florence. Unlike the first part, where a mere demonstration of Bess's virtues suffices to teach men to treat her correctly, Bess here is not in control of her body or the language used to describe her. Instead of Bess masterminding the action of the play as she did in Part I - commissioning the building of a ship to set sail on the English Channel, hatching a plot to teach Roughman a lesson, or even persuading Mullisheg of English virtue by demonstrating her willingness to die rather than be parted from Spencer - we find her dependent on the men around her. They defend her chastity and, for the most part, they determine her actions.

The first three acts of Part II outline the continuing adventures of Bess and her English cohorts in Fez, where Mullisheg has come to regret granting Bess permission to marry Spencer, and his attempts to force himself on Bess precipitate a number of acts of wit, courage and valour on the part of the English. His regret seems to function metonymically for Heywood's regret that he has let Bess behave so unconventionally in Part I. Part II opens with Tota, the Queen of Fez, who does not appear in Part I. Barbara Sebek has read Tota as Bess's dark double, a foil who 'renders overt the covert anxieties about our upwardly and geographically mobile tavern wench' ${ }^{59}$ In her reading, Part II displaces any anxiety that the viewer might feel about the upwardly mobile tavern wench of Part I by displacing Bess's subversion of gender roles on to a racialised Other, for, as Sebek notes, Tota is both a 'black Moor' and a 
'Moorish woman'. ${ }^{60}$ Tota's failed attempt to cuckold her husband intimates what might happen if Bess Bridges were not a paragon of chastity, and the Moorish Queen's frustration at her husband's neglect foreshadows the frustration that Bess will feel in Florence, when an unwitting vow by Spencer will temporarily keep the then-married couple apart. Claire Jowitt explicitly links these changes to a shift from an Elizabethan anxiety over female rulership to a Caroline understanding of the role of queen as royal companion, the model of queenship embraced by Henrietta Maria, one of the most prominent audience members at Part II's first performance. Interestingly enough, for Jowitt the most relevant historical queen for Part II is not Queen Elizabeth but Roxolana, the powerful wife of Sultan Suleiman I, who, like Tota, was 'represented as sexually predatory, manipulative, ruthless, and bloodthirsty, and a witch' ${ }^{61}$ Tota surfaces in the second part precisely to register anxieties that were specific to the 1630 s, and she becomes the foil, not for the upwardly mobile tavern wench of Part I, but for the solidly upper-class English maid and wife of Part II. Tota's racialised threat comes through as a dangerous Moorish womanliness rather than as girlishness.

Tota poses the danger of predatory womanly sexuality, and Bess in Part II embodies the danger posed to female chastity by male sexuality. In Part I, by contrast, the anxieties raised with regard to Bess's chastity stem from the other characters' perception of her identity, rather than physical threats. When Captain Goodlack returns from Spain and tests her faithfulness to Spencer in Part I, Bess has to refute his accusation that she has been a whore and prove her loyalty to Spencer, but the audience has never been in doubt. Bess's chastity has never truly been under siege. In Part II, on the other hand, the male characters repeatedly pose a physical threat, and her own desire to remain chaste remains insufficient to secure her identity as a chaste maid or wife. Oddly enough, this lack of female control over their own sexuality gets articulated in the beginning through an anxiety that wives will consciously but secretly betray their husbands in retaliation for neglect. Bess's trick with the Duke of Florence and Spencer at the end of the play turns out to be a mirror image of Tota's wifely revenge that rewrites female sexual transgression as chastity, an opposition that begins as one between different female life positions and ends by redefining womanhood as wifehood.

Rather than embodying multiple female identities in Bess, Part II splits them along racial and gendered lines between the two characters Tota and Bess. In the process of expressing rage over her husband's attentions to Bess and subsequent neglect of herself, Tota positions herself as a 'woman' in opposition to Bess, the maid. 'I should doubt', she says, 'I were a perfect woman, but degenerate / From mine own sex, 
if I should suffer this' (1.1.12-15). Tota defines a 'perfect woman' as one who takes revenge. This is inevitably influenced by Tota's role as the 'Other' woman, one who is married to a Moorish king and who is doubly 'Other' by not being Moroccan, though we never learn her nationality. Following as it does from the valorisation of girlhood in the play's first part, Tota's discussion of womanhood demonstrates the change of direction in the second. Whereas Bess's womanly and girlish behaviour in Part I promises to keep Roughman in line and promotes social order, Tota's womanly behaviour threatens to disrupt and corrupt English purity. As Howard and Jowitt have suggested, Part I displaces the rapacious sexuality that the English men fear in Bess on to the lustful Moroccan King of Fez, and it has the effect of feminising him even as his sexuality also threatens (quite literally in the case of Clem, who gets offered the position of Eunuch) to unman the English. ${ }^{62}$ What stands out in Part II, however, is the extent to which that feminisation gets localised in a female character. Yet for all her vengeful plans, Tota refuses to blame Bess for Mullisheg's treachery. Instead, she hatches a plot to sleep with Spencer, one that revenges her on her husband but does not cause him bodily harm. Tota employs Roughman to bring her to Spencer's bed on Bess and Spencer's wedding night, while Mullisheg, having changed his mind about letting Bess marry Spencer, employs Goodlack to bring Bess to his bed instead of Spencer's. The English, however, pull a bed trick and conduct the monarchs into each other's arms. This act of conventional comedic stagecraft, however, is not Bess's idea but Goodlack's. In contrast to Tota, who sees her womanliness as dependent on taking action and making plans, Bess is reduced in Acts 1 to 3 to making requests like 'Gentleman, amongst you all, rescue an innocent maid from violence' (2.1.65-6). As Kathleen McLuskie notes, 'Bess has lost her active role, and is the subject of others' passions. ${ }^{63}$

Through the events that transpire during the English group's attempt to escape, Mullisheg is eventually restored to virtue, but more through Spencer's virtues than Bess's. Spencer is separated from Bess and the others during their attempted escape, and she vows to commit suicide if he does not return alive to her ship. Having been captured by Bashaw Joffer, Spencer makes a pact with Bashaw Joffer, promising to return of his own accord after he returns to the ship to prevent Bess's suicide. Bess and the rest of the English crew urge Spencer to break his vow, but Spencer upholds his 'honour' and insists on returning despite Bess's protestations. Bess does, however, return to Mullisheg's court to try to rescue Spencer, a rare moment of her old resolve coming through in Part II. The spectacle of so much English bravery shames Mullisheg into behaving honourably. As the scenes from Fez draw to a close, Mullisheg 
once again calls Bess a 'girl', the last time she will be a 'girl' in the play: 'A golden girl th'art call'd, and, wench, be bold; / Thy lading back shall be with pearl and gold' (3.3.184-5). Accompanied with the gift of a wedding dowry, Mullisheg's label of 'golden girl' comes across as a vestigial remnant of an earlier identity. She is 'call'd' a 'girl' rather than actually being one here, and she will not be called one again. Bess and Spencer consummate their marriage at sea; from then on Bess's class position and chastity will be her defining characteristics.

After leaving Fez, the English are parted by a shipwreck, and Bess, Clem and Roughman wash up on a beach with Italian bandits. Left behind as Clem flees and Roughman tries to fight off one group, Bess is captured and threatened with ravishment. Gone is the Bess of the first part, who wielded a sword next to her followers. Instead, she has to be rescued by the timely appearance of the Duke of Florence. From that point forward, in accordance with her new class and marital status, the characters consistently refer to Bess as a 'lady'. In keeping with the emphasis on her sexual status, the metaphor of the 'girl worth gold' who is really worth more than gold transforms to a lady's worth being based upon her chastity. As the Duke says to Bess, 'You are richer in our high favour than / All the royalty Fez could have crown'd / Your peerless beauty with; he gave you gold, / But we your almost forfeit chastity' (4.1.144-7). After a series of more misunderstandings, Bess, Spencer and the English group eventually reunite, but not before another promise between men again disrupts the heterosexual marriage bonds. The Duke falsely claims that an unknown woman (Bess) is his mistress, and he extracts an unwitting vow from Spencer never to embrace her. In a parallel incident to the one in Fez where Spencer gave Bashaw Joffer his word of honour to return, Spencer's vow produces a misunderstanding between the lovers, since Bess cannot understand why her husband will not speak to or hold her. Her retaliation reveals much about her transformation from Part I and about the way Heywood attributes a lack of agency to his female character. In Part I, Bess calls herself 'a pattern to all maids hereafter / Of constancy in love' (3.4.93-4). In Part II, she declares herself a 'precedent / To all wives hereafter how to pay home / Their proud, neglectful husbands' (5.2.79-81). As a maid, Bess has active virtue; she loves and remains constant by choice. As a wife, she has the power to revenge, but her husband has the power to be inconstant, and her only recourse ostensibly lies in responding with her own inconstancy. Indeed, Bess's general impotency and inability to access the girlishness that served her so well in Part I leads her to behave in a remarkably similar manner to the Moorish queen from whom the play has worked to distinguish her. As Jowitt has rightly pointed out, 
in times of crisis 'Bess also places her personal satisfaction above the honorable claims of nationality or religion', collapsing the differences between the two women. ${ }^{64}$ Bess retaliates by pretending to become the Duke of Florence's mistress, kissing him in front of Spencer and seeming to call for Spencer's death. In the end, she turns the scene on its head, declaring that since she has the power of Spencer's life, she sentences him to spend his life with her as her husband and to forego any rash vows, a move that shows wives that they should be constant even in their inconstancy. Unlike Tota, however, whose threatened sexual transgression was foiled by the bed trick of the English, Bess's transgression was never meant to succeed in earnest. In fact, she transforms wifely transgression into reunion, undoing the sexual threat posed by the Duke of Florence's sexual aggression. Her love for Spencer converts the Duke, as her love for Spencer converts Mullisheg in Part I, but the difference lies in her methods. In Part I she comes boldly forth and declares her willingness to die on his behalf; in Part II she uses her wits, but she must do so in a covert way. Heywood grants her agency, but it has a different cast from the kind she exercises in Part I.

The effect of these differences appears quite vividly in the play's language. If Mullisheg declares that Bess will be reported as 'a girl worth gold' at the end of Part I, the Duke of Florence makes no such gesture in his concluding speech (5.2.147-53). His choice of words clearly contains Bess within the 'maid, wife, widow' paradigm: 'Thus much in your behalf we do proclaim: / The fairest maid ne'er pattern'd in her life, / So fair a virgin and so chaste a wife' (5.4.198-200). No longer does Bess disrupt categorisation; she has been narrated into the role of chaste wife.

Although I have used Fair Maid as a case study, Heywood's heroine seems to have been part of a general trend. The differences between the Bess of Part I and the Bess of Part II can also be seen in her fellow stage heroines. I will explore the Dekker and Middleton play The Roaring Girl in more depth in Chapter 2, but it is worth noting that, like the Bess of Part I, Moll Cutpurse was a cross-dressing, independent girl with a willingness to pick up a sword and fight. The girl characters that appeared on stage around the same time as the Bess of the second part of Fair Maid were significantly less powerful. T. B.'s The Country Girl was a comedy that was, like Fair Maid, evidently quite popular. Entered into the Stationers' Register in 1640 and published in 1647, The Country Girl was most likely being acted even earlier. It was later adapted for the Restoration Theatre Royal and republished under the name The Country Innocence: Or, the Chambermaid Turned Quaker in 1677. Copying the style of Middleton and Dekker's prologue to The Roaring 
Girl and providing a taxonomy for types of girls, The Country Girl's prologue refers to both Moll Frith and Bess Bridges:

Before I speake, me thinkes, I heare some say,

What can there be, to furnish out a Play,

In such a Home-spun Title?-In a Plaine

Poore Countrey Girle? Such, yeilds no lofty straine;

No sinewie stuffe, extracted from a Myne

Of deep and Abstruse reading; no strong line,

No such a straine, and this poore Title, lust

Like old Pan's Bagpipe, and Apollo's Lute.

What must we looke for then? A desperate wit?

Scoenes, full of veins, where, without a Hit

No man escapes, comes neere it? This indeed

Were to some purpose; and the way to speed.

But this too's from this Title.-None of these?

Alas poor Girle, where's then, thy hope to please?

What can she sing? And, like the Northerne Lasse,

(That brave blithe Girle) hope to procure a pass?

Or, can she fight?-If so so stout, so bold

A brave Virago, like the Girle worth Gold.

Or is she one, that once a Countrey Maid, Crack'd in the carriage, is come to Trade,

And set up some new Leaguer? Or suppose

Our Girle, a vertuous Copy, and so close

This inquisition of her, - She is-what?

Her owne presentment, best can tell you that,

Which be but pleas'd to grace, which love and favour,

You make the poore Girl rich, and Crown our labour. ${ }^{65}$

Although named after Margaret, the country girl, the play hardly revolves around her the way that The Fair Maid of the West does around Bess and The Roaring Girl around Moll. Margaret's eventual marriage to Captain George Mullinax is an afterthought, and Margaret is chiefly remarkable not for her feats of daring or for her smart business sense, but for her protection of her chastity. Courted by her father's landlord and patron Sir Robert Malory, Margaret refuses to compromise her chastity and collaborates with Sir Robert's wife Lady Malory to teach him a lesson. That lesson, however, does not involve Margaret besting Sir Robert in swordplay. Her family, at Lady Malory's request, dresses up in fine clothing and pretends not to know Sir Robert. Sir Robert is confused enough to admit his intentions with regard to Margaret and to vow his faithfulness to his wife. Otherwise, Margaret is singularly unremarkable for a title character.

Among the characters also seen as part of the tradition of girl characters mentioned in The Country Girl's prologue was Constance, 
the unremarkable heroine of The Northern Lass (written 1632, published 1684), who, like Margaret, exhibits none of the verve of Bess Bridges. Though the play itself was popular, the title character of Richard Brome's Caroline play seems to have been primarily notable for her singing. As a character, she provides a caricature of northern English dialect, and unlike Bess she neither embarks on adventures nor undergoes any kind of character development. Hopelessly in love with Sir Phillip Luckless, who has just been married to a wealthy widow, Constance the northern lass spends most of her stage time singing tunes to demonstrate her melancholy. That the music was the main attraction can be seen by the fact that the Stationers' Register records a copyright not only for the play, but also for its ballads.

The contrast between these later girl characters and Bess was not a coincidence but the result of a deliberate attempt to fashion a different kind of female youth. When Stephen Brome, the author's brother, wrote his prefatory poem to the 1632 quarto, he praises Constance precisely for not being like Bess:

Thy witty sweetnesse beares so faire a part.

Not a Good woman, nor a Girle worth Gold,

Nor twenty such (whoso gaudy shewes take hold

Of gazing eyes) shall in acceptance thrive

With thee, whose quaintnesse is superlative. ${ }^{66}$

By embedding a sexual pun on 'cunt' and 'quaint' in his praise of Constance, Stephen Brome makes it clear that she is a character whose sexuality defines her. Within the play itself, Luckless initially rejects Constance, the northern lass, because he confuses her with Constance, a local whore. By juxtaposing Constance's name with that of a whore, Brome scripts Constance into a narrative of female sexuality that defines women by their chastity or lack of chastity. ${ }^{67}$

What Bess's successors on the seventeenth-century stage suggest is that rigidifying the vocabulary of female youth corresponded to the perception of girls as less subversive and less powerful. That is not to say that there were no powerful female youthful characters in Caroline drama - far from it - but that the linguistic act of 'girling' a character on the stage seems more likely to be used to sexualise or belittle young women rather than mark their transgression of gender boundaries. The flexibility that enabled 'girl' to open up roles for Bess Bridges outside the 'maid, wife, widow' paradigm became muted over time. As the vocabulary of female youth became more precisely defined, characters like Bess in Fair Maid Part II lacked the power to define the terms that defined them. Once 'girl' could be incorporated into a taxonomic schema, it 
became part rather than disruptive of the 'maid, wife, widow' narrative. In the interim, however, 'girl' had the power to create an imaginative space in which female roles could go beyond prescriptive positions and fair maids could also be golden girls.

\section{Notes}

1. Thomas Cooper, Bibliotheca Eliotae (London, 1548), title page. The number of editions of Elyot's dictionary and Cooper's revision attests to their popularity. Elyot's first edition was published in 1542 with errata and was followed by a corrected edition in 1545. Cooper's revision followed in 1548 along with three subsequent expanded editions in 1552, 1558 and 1559. The endurance of this particular dictionary can further be seen in its forming the basis for Thomas Bestney, Thesaurus Linguae Romanae \& Britannicae (London, 1587).

2. The title page's terms 'castigate' and 'augment' might at first appear to work against each other but are not contradictory in terms of Cooper's lexical project. The Latin root verb castigare means 'to chastise, correct, or reprove', with connotations of purifying and chastening, whereas augmentare means 'to increase'. The reproductive associations of the latter would seem at first glance to contradict the anti-proliferation with which we might associate the former. For Cooper, however, to give a more accurate and purer signification of words importantly did not mean paring down the number of English alternatives but increasing them.

3. Stanley Cavell, 'Excursus on Wittgenstein's Vision of Language', in The Claim of Reason (Oxford: Oxford University Press, 1999), pp. 177-8.

4. For an in-depth discussion of these terms and their histories from the perspective of linguistics, see Grzegorz Kleparski, Theory and Practice of Historical Semantics: The Case of Middle English and Early Modern English Synonyms of Girl/Young Woman (Lublin: University Press of the Catholic University of Lublin, 1997).

5. For an insightful discussion of the importance of the category 'maiden' in the Middle Ages, see Kim M. Phillips, Medieval Maidens: Young Women and Gender in England, 1270-1540 (Manchester: Manchester University Press, 2003). Phillips's book tellingly ends around the time that 'girl' was emerging as a gender-specific term in the sixteenth century.

6. Robert Herrick, Hesperides, or, The Works Both Humane and Divine (London, 1648), sig. S7r.

7. This and all future quotations from this play are from Thomas Heywood, The Fair Maid of the West, Parts I and II, ed. Robert K. Turner, Jr. (London: Edward Arnold, [1631] 1968).

8. Valerie Traub, The Renaissance of Lesbianism in Early Modern England (Cambridge: Cambridge University Press, 2002), p. 171.

9. Ibid. pp. 171-2.

10. Hester Pulter, Poems breathed forth by the nobel Hadassas, and The Unfortunate Florinda, University of Leeds Library, Brotherton Collection, MS Lt q 32, 92-7. 
11. The Norton Shakespeare, p. 880, 1.3 n. 1.

12. Juliet Fleming, 'Dictionary English and the Female Tongue', in Richard Burt and John Michael Archer (eds), Enclosure Acts: Sexuality, Property, and Culture in Early Modern England (Ithaca: Cornell University Press, 1994), pp. 290-325. See also John E. Joseph, Eloquence and Power: The Rise of Language Standards and Standard Languages (New York: Blackwell, 1987).

13. Michel Foucault, The Order of Things: An Archaeology of the Human Sciences (New York: Routledge, 2002).

14. 'Girl' only appeared in these 'hard word' dictionaries when it meant 'A Roe Bucke of two yeares', as in John Bullokar, An English Expositor: teaching the interpretation of the hardest words in our language (London, 1616). Otherwise, 'girl' was an everyday term and was translated rather than explained.

15. John Florio, A Worlde of Wordes, or Most Copious, Dictionarie in Italian and English (London, 1598), sig. F1r.

16. Giovanni Torriano, Vocabulario Italiano e Inglese (London, 1659), sig. $\mathrm{N} 2 \mathrm{v}$.

17. As I will discuss further in Chapter 4, historians disagree over the extent to which girls would have experienced formal apprenticeship. K. D. M. Snell argues that there were a greater variety of positions available to women than previously thought, whereas Ilana Krausman Ben-Amos points out that most women were apprenticed as domestic labourers rather than as part of the formal guild system. See Snell, 'The Apprenticeship of Women', in Annals of the Labouring Poor: Social Change and Agrarian England, 1660-1900 (Cambridge: Cambridge University Press, 1985), pp. 270-318, and Krausman Ben-Amos, Adolescence and Youth in Early Modern England (New Haven: Yale University Press, 1994), p. 135.

18. Sara Mendelson and Patricia Crawford, Women in Early Modern England, 1550-1720 (Oxford: Oxford University Press, 1998), p. 39, pp. 96-7.

19. Krausman Ben-Amos, Adolescence and Youth, p. 7.

20. A New English Dictionary Shewing the Etymological Derivation of the English Tongue (London, 1691), sig. Q6r.

21. Ibid. sig. L5v.

22. Samuel Johnson, Dictionary of the English Language (London, 1786), Vol. 1 , sig. 5Bv. Johnson also remarks upon the uncertain etymology of 'girl' and provides an account of various lexicographers' explanations, including Minshew's association with the Latin garrula or 'prattler'. He also reports Junius's speculation that 'girl' may be related to the Welsh herlodes, related to the English word 'harlot', but this trace of the association between girlhood and promiscuity remains the only remnant of the earlier, more wide-ranging connotations of girlhood. Johnson's choice of quotations illustrating the meaning of 'girl' includes several from Shakespeare, and they emphasise the definition of 'girl' as a young woman.

23. Ibid. Vol. 1, sig. 2B3v. Johnson also records two supplementary entries for 'boy'. The first notes that the word signifies 'one in the state adolescence; older than an infant, yet not arrived at puberty or manhood' and the second that 'boy' can be a derogatory term signalling the immaturity of young men. 
24. The linguist Anne Curzan's work on language and gender confirms my sense that girls are the default association when it comes to children. She writes, 'Historically, there is an observable tendency to use sex-specific terms for male children in contrast to gender-neutral terms for children, which then must be assumed to refer to girls ... It may be that for children, as opposed to adults, girls are the more culturally salient subset.' See her Gender Shifts in the History of English (Cambridge: Cambridge University Press, 2003), p. 157.

25. Johnson, Dictionary, Vol. 2, sig. B2v.

26. Ibid. Vol. 2, sig. I4r.

27. Ibid. Vol. 2, sig. I4v.

28. See Roman Jakobson, 'The Concept of Mark', in Linda Waugh and Monique Monville-Burston (eds), On Language (Cambridge, MA: Harvard University Press, 1990), pp. 134-40.

29. Barrie Thorne and Nancy Henley, 'Difference and Dominance: An Overview of Language, Gender, and Society', in Thorne and Henley (eds), Language and Sex: Difference and Dominance (Rowley, MA: Newbury House, 1975), p. 15.

30. For an account of the way that men appropriated the midwifery profession in the eighteenth century, see Adrian Wilson, The Making of ManMidwifery: Childbirth in England, 1660-1770 (Cambridge, MA: Harvard University Press, 1995).

31. William Langland, The Vision of Piers Plowman, ed. A. V. C. Schmidt (London: Everyman, 1995), p. 149.

32. See Curzan, Gender Shifts, pp. 148-9.

33. John Palsgrave, Lesclarcissement de la langue francoyse (London, 1530), sig. C.lxix.

34. Hanna Scolnicov, 'Ages of Man, Ages of Woman', Cahiers Elisabéthains 56 (2000), p. 61.

35. John Amos Comenius, Orbis Sensualium Pictus, trans. Charles Hoole (London, 1659), p. 77.

36. See Kleparski, Theory and Practice of Historical Semantics, p. 129.

37. Muriel R. Schulz, 'The Semantic Derogation of Woman', in Thorne and Henley (eds), Language and Sex, p. 65.

38. See Kleparski, Theory and Practice of Historical Semantics, p. 143.

39. Thomas Middleton and Thomas Dekker, The Roaring Girl, ed. Paul Mulholland (Manchester: Manchester University Press, [1611] 1987).

40. John Harington, 'The Author to a Daughter of nine yeere old', in The Most Elegant and Witty Epigrams (London, 1618), Epigram 75, sig. D2v.

41. See the following passage on the falling, which states that if it is developed 'after thee byrth by some accidentall causes' that ' $y f$ it leaue not the chylde beyng a man chylde before he be .xxv. yeare of aege / and the woman chylde about the tyme of hauing her fyrste flowers, yf it forsake them not in this space / neyther by the myght of nature / neyther of medycynes / then is it lyke neuer to depart frome them.' Eucharius Rösslin, The Byrth of Mankynde, trans. Richard Jonas (London, 1540), sig. LXXVIr.

42. Ibid. sig. LXXXIIIIv-LXXXVr.

43. Thomas Raynald, The Byrth of Mankynde, or the Womans Book (London, 1552), sig. Diiiv. 
44. Jacques Guillemeau, Child-birth, or The Happy Deliverie of Women (London, 1612), sig. A4v.

45. Ambroise Paré, The Workes of that famous Chirurgion Ambroise Parey, trans. Thomas Johnson (London, 1634), fo. Eeee6r.

46. Jane Sharp, The Midwives Book, or the Whole Art of Midwifry Discovered, ed. Elaine Hobby (Oxford: Oxford University Press, [1671] 1999), p. 19.

47. Ibid. p. 69.

48. Ibid. p. 38 .

49. Both Roxana Stuart and Jennifer Low situate Bess Bridges amongst female dramatic characters who engage in on-stage duels, Stuart emphasising cross-dressing and Low the connection between verbal and physical sparring. See Stuart, 'Dueling en Travestie: Cross-Dressed Swordfighters in Three Jacobean Comedies', Theatre Studies 38 (1993), pp. 29-43, and Low, "Women are Wordes, Men are Deedes": Female Duelists in the Drama', in Linda Woodbridge and Sharon Beehler (eds), Women, Violence, and English Renaissance Literature: Essays Honoring Paul Jorgensen (Tempe: Arizona Center for Medieval and Renaissance Studies, 2003), pp. 271-302.

50. Charles Crupi, 'Subduing Bess Bridges: Ideological Shift in the Two Parts of The Fair Maid of the West', Cahiers Elisabethain 54 (1998), p. 76; Barbara Sebek, "'Strange Outlandish Wealth": Transglobal Commerce in The Merchant's Mappe of Commerce and The Fair Maid of the West, Parts I and II', in John Gillies and Virginia Mason Vaughn (eds), Playing the Globe: Genre and Geography in English Renaissance Drama (Madison, NJ: Fairleigh Dickinson University Press, 1998), pp. 176-202; Claire Jowitt, 'East versus West: Seraglio Queens, Politics, and Sexuality in Thomas Heywood's Fair Maid of the West, Parts I and II', in Galina I. Yermolenko (ed.), Roxolana in European Literature, History and Culture (Aldershot: Ashgate, 2010), pp. 57-70.

51. See Warren E. Roberts, 'Ballad Themes in The Fair Maid of the West', Journal of American Folklore 68 (1955), p. 19. Roberts has traced Fair Maid's connection to two major ballad themes from the British tradition: the first is 'the lover who returns from the wars and tests his sweetheart', and the second is 'the maiden who disguises herself as a sailor or soldier and follows her lover to sea or to the wars'. The first theme of the lover returning from war can be seen in such seventeenth-century ballads as 'The Valiant Seaman's Happy Return to His Love' (1676), 'A Pleasant New Song Between a Seaman and His Love' and 'The Pensive Maid' (1672-80). Roberts speculates about whether the ballads are the source of the play or the play the source of the ballads and concludes that both must be derived from a previous common source, probably earlier ballads.

52. Jean E. Howard, 'An English Lass Amid the Moors: Gender, Race, Sexuality, and National Identity in Heywood's The Fair Maid of the West', in Margo Hendricks and Patricia Parker (eds), Women, 'Race,' and Writing in the Early Modern Period (New York: Routledge, 1994), p. 107.

53. Ibid. p. 109.

54. Ibid. p. 106.

55. Quoted in Gerald Eades Bentley, The Jacobean and Caroline Stage, Vol. IV (Oxford: Clarendon, 1956), p. 569. 
56. T. B., The Country Girle (London, 1647), sig. A4v.

57. See W. W. Gregg, A Bibliography of English Printed Drama to the Restoration (London: Bibliographical Society, 1970), p. 1, p. 67.

58. Quoted in Bentley, The Jacobean and Caroline Stage, Vol. IV, pp. 569-70. The original manuscript is BL Sloane 1900, fo. 60-3.

59. Sebek, 'Strange Outlandish Wealth', p. 192.

60. Ibid. p. 191.

61. Jowitt, 'East versus West', p. 57.

62. Howard, 'An English Lass Amid the Moors', p. 109; Jowitt, 'East versus West', p. 61.

63. Kathleen McLuskie, Dekker and Heywood: Professional Dramatists (New York: St. Martin's Press, 1994), p. 141.

64. Jowit, 'East versus West,' p. 67.

65. T. B., The Country Girle, sig. A4v.

66. Stephen Brome, 'To his ingenious Brother M RICH. BROME', in Richard Brome, The Northern Lass (London, 1632), sig. A3v.

67. It is hard not to agree with Samuel Pepys, who said of a performance of The Northern Lass in 1667, 'Knipp acted in it, and did her part very extraordinary well, but the play is but a mean, sorry play.' Quoted in Bentley, The Jacobean and Caroline Stage, Vol. III, p. 82. 


\section{Roaring Girls and Unruly Women: Producing Femininities}

In England's Merry Jester (1693), the writer J. S. relates a story in which a pert ten-year-old girl reveals the pressure that girlhood could place on early modern gender ideologies. When admonished by her mother for not looking at the ground when speaking to men, the girl points out, first, that her mother's lesson on female submission has come too late and, second, that there is nothing natural about women deferring to men:

A Girl about ten years old, had got a trick of confidently staring in mens faces when they were talking; for which her mother reproved her, saying Daughter, our Sex enjoins us Modesty, and you ought to be bashful, and look downward when you are in mens company, and not to stand gazing and gaping as if you were looking babies in their eyes: to which the pert girl replied, This lecture forsooth, should have been read in my former ignorant Ages, but every age grows wiser and wiser; that maids of every age know better: Men indeed, may look down on the primitive dust, from whence they were taken, but Man being our original, I will stare in their faces, say what you can to the contrary. ${ }^{1}$

This jest functioned as the kind of disruptive 'vector of critique' that Pamela Allen Brown discusses in her book Better a Shrew than a Sheep: Women, Drama, and the Culture of Jest. As Brown has shown, women were actively involved with jest literature - collecting, revising and reiterating jokes within the household and the larger community. ${ }^{2}$ The mother may be the object of the girl's defiance, but the primary targets of the girl's disdain are the men who claim to be superior to women, making the oral repetition of the jest an occasion for communal female laughter at the expense of men (and women) attempting to enforce outdated social codes. With this jest book, the announcement in the title that the jests have been fashioned to be 'suitable to the humours of the times' seems particularly relevant. The girl in this jest becomes a vehicle for articulating the ways that female children could be indoctrinated 
into subordinate subject positions via education and the corresponding ways that they could refuse those positions precisely because they were learned. By denying the social hierarchy on which her mother's directive is founded, the girl - and I would suggest it is significant that J. S. labels her a 'girl' - performs a defiant form of biblical exegesis. Early modern debates about the relationship between the sexes often focused on Genesis. Whereas misogynists used Adam's precedence as proof of male superiority, defenders of women harnessed the same information to argue for equality. ${ }^{3}$ This girl imitates the defenders, but takes it one step further. Men, she suggests, should modestly gaze at the ground, since they came from it.

The daughter's response exposes the tension between what conservative social customs maintained women 'ought' to be and what women actually 'were'. The very need to control female behaviour, to insist that the female 'Sex enjoins ... Modesty', exposes the fact that women were not naturally modest but that modesty was imposed upon them through social and cultural restraints. Although early modern structures of power deployed assumptions about a 'natural' order, the need to reproduce gender hierarchies through systems of social control revealed the subjugation of women to men as a powerful but artificial institution - one that needed to be ingrained in children while they were still young and malleable. Otherwise, as this girl suggests, a female child who came into maidenhood would be too wise to accept the status quo.

This chapter is about three female characters who, like the girl in this jest, stared men in the face, whatever social pressures were in place to prevent them from doing so. In the three texts I examine George Gascoigne's The Adventures of Master F. J. (1573), William Shakespeare's The First Part of Henry the Sixth (1592) and Thomas Middleton and Thomas Dekker's The Roaring Girl (1611) - early modern conversations revolving around children in general and female youth in particular gave rise to female characters who challenge the boundaries of the early modern sex-gender system. Though not female children, Gascoigne's Elinor, Shakespeare's Joan la Pucelle and Middleton and Dekker's Moll Cutpurse occupy gendered positions inextricably linked to their identifications as 'girls'. These writers drew on the innovations taking place in the vocabulary of female youth to participate in the fashioning of a discourse of girlhood that consistently marked it as a time of relative freedom compared to womanhood, which even in its idealised form was nonetheless signified as a time of containment. As a result, the term 'girl' seems to have been mobilised to describe adult women who were sexually, but perhaps more importantly socially and politically, transgressive. Through their girl characters, 
these three texts expose gender as an irreducible social fiction rather than a biological fact, and they construct early modern femininities as multiple and performative rather than singular and natural - as learned behaviours, rather than expressions of inborn traits.

To move from an investigation of language itself to an investigation of the way language produced multiple categories of femininity and femaleness, I am going to read these texts in tandem with prescriptive educational manuals in which early modern writers were acutely aware that female human beings had to be trained to be 'women'. I am doing so to suggest that paying attention to the category of the 'girl' does for the sixteenth and seventeenth centuries what Monique Wittig sees as one of the goals of materialist feminism, namely the destruction of women as a 'natural group', that is, 'a racial group of a special kind, a group perceived as natural, a group of men considered as materially specific in their bodies' ${ }^{4}$ I am not suggesting, of course, that we disregard female bodies or the particularities of women's experiences. I agree with Sara Mendelson and Patricia Crawford that female bodies as well as the discourses about them were central to early modern women's lives. As they note, sexual difference 'is not just a matter of discourse but "has a bodily dimension"'. 5 But not all early modern female human beings would have experienced their bodies in the same ways, and simply the fact of having a female body does not create a shared cultural experience. What I am suggesting is that we need to think of the term 'women' as a social relation rather than a biological fact, and that the addition of the term 'girl' to our critical vocabularies forces us to do so; as Judith Butler reminds us, the gendered subject is always constituted and brought into existence by the very power structures that claim to represent the subject. ${ }^{6}$ What early modern girlhood contributes to today's feminist theory - and what I would add to Wittig's and Butler's insights - is this: the category of 'women' (which Butler identifies as the 'subject of feminism') is not the only female subject position brought into existence through structures of power. It's crucial that we look at the historical specificity of the way that other subject positions, such as 'girl', have been constituted discursively, socially and culturally, and how those positions have overlapped with and been distinct from 'woman'.

Feminist theorists have long recognised that definitions of masculinity and femininity are historically and culturally contingent, and although the terms themselves get recycled, their definitions 'are never settled once and for all but are constantly in the process of being remade'. I want to start by pointing out the way girlhood complicates the linear trajectory between the two models of early modern femininity that Anthony Fletcher describes as a shift from a negative to a positive model 
of gender difference. Although he acknowledges that the process happened unevenly and gradually, Fletcher suggests that an older misogynist view of women as inherently corrupt and undesirable gave way over the course of the sixteenth and seventeenth centuries to a more companionate view of women as men's complementary opposites. This was the result, Fletcher suggests, of women internalising prescriptive moral advice about how to be good wives and mothers, and he claims the effects were twofold. First, cultural representations - from conduct books to pamphlets and plays - came to portray chaste, silent and obedient behaviour as 'natural' to women rather than the result of careful education. Second, this 'naturally' chaste femininity replaced the older notion of 'naturally' unruly femininity. ${ }^{8}$ In a more genre-specific analysis, Karen Newman has traced a similar shift in conduct manuals, from writers aiming to fashion female individuals into appropriately chaste feminine subjects to later Protestant-inflected treatises portraying a companionate model of feminine subjectivity. Newman, I want to emphasise, provides a nuanced and politically aware account, and she sees the shift in conduct literature not as a change in women's status but as a change in how they were 'interpellated as social and sexual subjects'. Throughout her account, Newman makes it clear that naturalness was a social production.

Nonetheless, I want to trouble this narrative by pointing out that any simple 'masculine/feminine' binary was complicated by the existence of multiple femininities; the very notion of a negative form of femininity presupposes the existence of its opposite, and as I will argue, early modern conduct literature and education manuals never unequivocally represented gender as 'natural'. Behaviour coded as 'unfeminine' at certain moments was coded as quintessentially 'feminine' at others, making it very hard to maintain a simple teleology in the progression of the female life cycle. The representation of what I will be calling girlish femininity in texts like The Adventures of Master F. J., 1 Henry VI and The Roaring Girl had a way of exposing womanly femininity as a constructed patriarchal fantasy of idealised female subordination. Rather than seeing one set of gender determinants replacing another, I want to hold these definitions together and suggest that the concept of 'girlishness' made both types of femininity into performative acts. Rather than seeing a progression from 'naturally' bad femininity to 'naturally' good femininity, or from 'constructed' femininity to 'natural' femininity, I suggest that these texts figure competing models of femininities as sets of behaviours that form social relations, not as pre-discursive biological facts. 
The precondition for the construction of girlishness as an alternative form of femininity was the formulation of gender itself as acquired rather than 'natural'. Early modern conduct literature was part of a larger tradition of children's education that characterised children of both sexes as particularly susceptible to evil yet apt to be formed into good members of the Christian commonwealth. Adapting the classical tradition's emphasis on early oratorical instruction, early modern teachings emphasised the importance of raising children in the knowledge of Christ, 'even from their very cradles'. ${ }^{10}$ In the cradle of religious debate, children occupied contested ground - quite literally with regard to saving their souls while in the cradle. Post-Reformation religious writings positioned infants in the middle of a struggle between the Catholic, Protestant and sectarian movements for the future of England's religion. Raising children as part of a particular faith was seen as necessary to each religion's continuation, and doing so was seen as God's particular charge for every parent. Otherwise, in the words of Lady Grace Mildmay, children's minds would be tainted and corrupted 'even from their infancy'. ${ }^{11}$ Ilana Krausman Ben-Amos has shown that despite Protestantism's emphasis on the need for grace from God and the propensity of all human beings to sin, conduct manuals and Protestant autobiographies nonetheless shared with Catholicism a belief in the peculiar susceptibility of children. The main difference that she sees is that Protestant writers were more likely to emphasise the potential sins of parents who did not do enough to protect their children rather than the sins of the children themselves. ${ }^{12} \mathrm{Hugh}$ Cunningham likewise points to slight differences between Protestant and Catholic attitudes toward the importance of bringing up children in the Christian faith, partly because Catholic parents, unlike Protestant ones, were more likely to be reassured that their child's soul had been saved by infant baptism. He suggests that Reformation and CounterReformation writers share a preoccupation with the religious education of children but that what distinguishes Protestant conduct manuals is the emphasis on the family's (rather than the Church's) role in conducting that education. Because Protestants saw the family as a kind of mini-Church, the responsibility for making Christian children shifted from church ceremonies and sacraments to the parents and educational figures. ${ }^{13}$ The result was that in religious education, the emphasis on beginning instruction in female infancy in Protestant writings centred on the place of the female child in the household, a habit so strongly ingrained that in Elizabeth Isham's Book of Remembrance she explic- 
itly thanks God for letting her be born to parents who had her baptised and raised in the Church:

And hearein I call to mind thy goodnes $\mathrm{O}$ Lord in caussing me to be borne of religious parents: who brought me into thy Church, to receve the Blessed Sacrament of Baptisme even the seale of regenaration; which was on Sunday for which I praise my God that I had the praiers of a full Congregation that I might be one of thy flooke; for which I praise thee. ${ }^{14}$

A similar praising of good Christian caretakers appears in John Duncon's 1649 account of the life of Lettice Cary, Viscountess Falkland, whose religious zeal supposedly began in the cradle: 'There were care taken while she was young, that she should be brought up in the nurture and admonition of the Lord; She came not from her Nurses arms without some knowledge of the principles of Christian religion. ${ }^{15}$ Duncon's claim may seem hyperbolic, but in light of anxieties like Grace Mildmay's about the susceptibility of children, it is in keeping with early modern cultural fantasies about the impressionable state of infants and the need to bring them up as good Protestants. Even at a 'tender age', children were never too young to begin their religious educations, and it was the responsibility of their caretakers to provide it. ${ }^{16}$

The key point to remember is that the notion of children as tainted with original sin and in need of spiritual education existed in tension with narratives of miseducation, and ideas about the acquisition of gender exhibit similar frictions between nature and nurture. As Rebecca Bushnell has shown, humanist metaphors likening education to gardening posit innate, natural differences between male and female minds, yet insist upon the need for proper cultivation in order for the seed to grow into a healthy plant. Children might 'naturally' follow a bad course if left to their own devices, but they still had a course to follow. The 'natural' in this theoretical system exists within a cultural framework, particularly when it comes to gender. Sixteenth-century humanist educational treatises represented femininity, like masculinity, as an educational product, and their educational programmes implicitly and explicitly aimed to fit children for their future social positions. Girls and boys alike were being fitted to fulfil roles inflected by gender and class, and those roles were not straightforward extensions of inborn proclivities, particularly when it came to female infants and children. ${ }^{17}$ As Bushnell has shown, humanist pedagogical theories were pulled in two directions, toward an insistence on a universal human rationality on the one hand and an insistence on women's natural mental inferiority on the other.

Not surprisingly, representations of the natural weaknesses of female children in humanist educational manuals often exist in tension with 
the sense that female minds therefore need cultivation. We can see such a tension in the work of the Spanish humanist Juan Luis Vives, who remarks at the opening of his influential Instruction of a Christen Woman, translated by Richard Hyrde and published in 1529, that if a boy's 'begynnyng and entrance' into oratorical training should be 'taken from the cradell', then 'moche more diligence ought to be given in a Christen virgine'. ${ }^{18}$ With an emphasis on the acquisition of morals and personality traits rather than learning a set of skills, Vives depicts raising up a girl from the cradle as absolutely crucial to forming her into a social subject. Of course, the same could be said of princes; Erasmus and Thomas Elyot both advocated instructing royal boys and noblemen earlier than private individuals, but Vives's admonitions were not meant to groom her to rule as sole monarch but to be ruled over by a Christian husband. What made humanist attitudes toward the early education of female children different from their attitudes toward male children was that they insisted girls needed training to acquire gender much more so than wisdom.

As such, the formal and informal educational systems of sixteenthand seventeenth-century England aimed to inculcate particular kinds of femininity that fitted the social roles that female individuals were expected to fulfil. Humanist pedagogical theories 'orient themselves doubly - to the nature inherent in gender and rank and to social function'. ${ }^{19}$ That is to say, humanist beliefs about female dispositions having inherently different properties from male dispositions could be held in tandem with beliefs about the need to produce femininity in those female dispositions. Vives expresses the belief that women 'be more disposed to pleasure and dalyance', and yet his conviction functions to reinforce the need for maids to learn via 'custom' to be honest and virtuous. ${ }^{20}$ Vives's educational treatise still relies upon the notion of Christian femininity as a learned behaviour. He is not just describing what a good Christian woman should be but providing practical advice for how to make female children into one. Though he acknowledges that Xenophon, Aristotle, Plato, Jerome, Ciprian and Ambrose 'have entreated of maydes and wydowes', he claims they have done so in ways 'that they appere rather texhort and consayle them unto som kynde of lyuing, than to instruct and teche them'. ${ }^{21}$ Whereas his classical predecessors had praised female virtues, Vives seeks to provide tangible, material ways to instil them. As conservative as Vives's ideas about female education may have been, they have the effect of exposing feminine behaviour as a social production.

It is crucial to note that the production of aristocratic femininity left out a significant number of female individuals from being able 
to be produced into the category of 'women' - including members of the lower classes and non-Christians. Compared to other educational manuals, the sentiments of Vives's book were decidedly aristocratic in their preoccupations. Admittedly, The Instruction of a Christen Woman (De institutione foeminae Christianae) has been argued to have had a broader appeal, primarily based on the number of editions and the inclusion of the word foeminae rather than principis in the title, a departure from previous pedagogical tracts aimed at royalty. ${ }^{22}$ As a result, Vives's manual has been widely seen as the most influential sixteenth-century text on women's education, having gone through nine English and over forty European editions, including translations from the original Latin into Dutch, French, German, Italian and Spanish. Nonetheless, what constituted a woman, and hence what constituted ideal Christian femininity, was inseparable from class in Vives's manual. It was written for Catherine of Aragon in 1523 and intended as a guide for the studies of then Princess Mary Tudor. If the text was indeed as popular as the number of reprintings suggests, its success most likely resulted from bourgeois class aspirations, rather than the applicability of Vives's advice to the general female populace, very few of whom would have had the same educational needs as the Princess Mary. The crucial difference between Vives and later humanist texts that engage with a discourse of girlhood is that he describes women as possessing various degrees of one type of femininity rather than possessing multiple types of femininities, an effect heightened in Hyrde's translation, which translates the Latin puella as 'mayde' in the early chapters on female youth, as in the title of Book 1, Chapter 4, which Vives labelled ' $D e$ Doctrina Puellarum' but Hyrde renders as 'Of the lernyng of maydes'. ${ }^{23}$ Completing the translation right on the cusp of the period in which 'girl' emerged as a gender-specific term, Hyrde picks up on Vives's emphasis on chastity, relying on the 'maid, wife, widow' formulation of the female life cycle, which corresponds to the three books of the treatise. The category of the 'girl' does not exist in the English translation of Vives. Until the female children in the manual had been properly interpellated into womanly subject positions, they could not be properly said to be feminine, and hence not properly 'women'. Consequently, the treatise excludes a number of people with female bodies from the category of the 'Christian maid' and 'woman'. ${ }^{24}$

Richard Mulcaster's Positions Concerning the Training Up of Children (1581), on the other hand, formulates a distinctly girlish form of female behaviour that was recognisably feminine and recognisably different from Vives's chaste, silent and obedient version of femininity. Like most humanist tracts on pedagogy, Positions focuses on the 
education of boys; girls and young maidens appear only in a brief sidebar on women's education. Yet despite Mulcaster's brevity, his remarks illuminate the association in early modern culture between 'natural' femininity and girls. Mulcaster advocates that parents and teachers follow the same set of principles when setting a plan of study for girls as they do for boys, customising the programme depending on the aptness and abilities of the pupil. The difference for Mulcaster lies in the 'natural' abilities of girls compared to the 'natural' abilities of boys. As Rebecca Bushnell has shown, humanists like Mulcaster assumed that girls 'by nature follow a different life cycle', and therefore ought to follow a different educational path. ${ }^{25}$ While Mulcaster initially pays lip service to equal access to education for girls, he undercuts such a claim through an appeal to girls' weaknesses:

For though the girles seeme commonly to have a quicker ripening in witte, then boyes have, for all that seeming, yet it is not so. Their naturall weaknesse which cannot holde long, delivers very soone, and yet there be as prating boyes, as there be pratling wenche. Besides, their braines be not so much charged, neither with weight nor with multitude of matters, as boyes heades be, and therefore like empty caske they make the greater noise. As those men which seeme to be very quicke witted by some sudden pretie aunswere, or some sharp replie, be not alwaye most burthened, neither with lettes, nor learning, but out of small store, they offer us still the floore, and hold most of the mother. ${ }^{26}$

Acknowledging with discomfort what many contemporary educators have also noticed - that young girls often learn more quickly than young boys $^{27}$ - Mulcaster attempts to explain the phenomenon not in terms of social practices but in terms of what is natural to girls and boys. Girls 'naturally' have weaker brains, making them more impressionable but less likely to hold impressions; boys have harder wits that take longer to imprint but that fix impressions more firmly. This representation of the female mind corresponds to the common poetic device of metaphorising women's hearts as waxen, easily taking the impression of a seal and just as easily melting to receive a new impression. However, Mulcaster undercuts his own attempt to set up this 'natural' gender difference along biological lines through his attempt to explain away girls' quick wits. His cross-sex example of the way quick-witted men mask their empty heads with sharp retorts unsettles his attempt to ground sexual difference in male and female brains. His example turns the biological into the behavioural, the general into the specific.

As an intellectual version of a common poetic trope, the idea that quick wits lack retention was not unique to Mulcaster. Roger Ascham had made a similar claim eleven years earlier in The Scholemaster (1570) 
in a way that likewise drew connections between gender and intellectual capacity. 'Quicke wittes', Ascham insists, 'commonlie be apte to take, unapte to keepe. ${ }^{28}$ The traits that Ascham identifies as characteristic of the 'quickest wittes' read like a laundry list of the charges made against unwomanly women. They are 'in desire, newfangled, in purpose, unconstant, light to promise any thing, readie to forget every thing . . . bolde, with any person: busie, in every matter: soothing, soch as be present: nipping any that is absent'. ${ }^{29}$ These are exactly the kind of behaviours that would come to be regarded as girlish in adult women. Mulcaster's incorporation of Ascham's argument into his own takes an implied connection between quick wits and effeminate behaviour and makes an explicit link to girls; even as Mulcaster attempts to ground this kind of gender difference in the body, the very fact that male and female brains can be 'unconstant' and 'light' and 'forgetful' undermines his attempts.

Indeed, it is precisely the need to shape the female subject that fuels the need to clearly articulate the competing models of femininities. Conduct manuals frequently conflated Christian behaviour with gendered behaviour, mapping a moral valence on to what the writers considered socially appropriate for men and women. Being feminine in a particular way thus took on a religious and moral imperative, and these writers aimed to ensure that girls aspired to become women who fulfilled prescribed roles within the existing sex-gender system. Thomas Becon, for example, incorporated the admonitions that we associate with conduct manuals into A New Catechisme, a dialogue between a father and his precocious son, a boy who talks more like an adult than the five-year-old he is purported to be. The catechism dramatises the process through which children acquired religious knowledge at the same time that it harnesses doctrinal and scriptural interpretations in the service of inculcating social values. Rather than portraying what he considered appropriate feminine behaviour as natural, Becon, like Vives before him, figures it as the product of a religious upbringing, and his catechism lays the groundwork for seeing girlhood as a potentially disruptive and empowering state because he figures it as a site of resistance to becoming an appropriately chaste, silent and obedient woman, one that is consciously adopted by unruly adult women.

Becon's emphasis on educating children and bringing them up in the Protestant faith reveals an awareness that children have to be taught social behaviour, particularly gendered social behaviour. Education, according to Becon's father and son, is the key to ensuring that women are not idle, so much so that the son actually calls for the establishment of schools for women. In a move that perversely anticipates arguments by eighteenth-century feminists like Mary Wollstonecraft and Mary 
Astell, the father and son suggest that if women and girls were better educated, they would be better members of society:

Father: If all our maids and young women were thus brought up, we should not have so many idle, unhonest, and lewd women, as we have at this present day.

Son: To bring this thing to pass, it is expedient that by public authority schools for women-children be erected and set up in every Christian commonweal, and honest, sage, wise, discreet, sober, grave, and learned matrons made rulers and mistresses of the same, and that honest and liberal stipends be appointed for the said school-mistresses, which shall travail in the bringing up of young maids, that by this means they may be occasioned the more gladly and willingly to take pains. And to this end without doubt at the beginning were the monasteries of solitary women, who we heretofore called nuns, built and set up, and endowed with possessions of our godly ancestors, although in process of time they were greatly abused. ${ }^{30}$

As Wollstonecraft and Astell would later link women's ignorance to faulty educations, the father and son blame the number of 'idle, unhonest, and lewd women' on their defective upbringings. Unlike those eighteenth-century feminists, however, the main concern in Becon is not improving the state of women. The schools that the son envisions would not be aimed at bettering the social position of women; they would instead be instruments of social control - the very embodiment of what Louis Althusser would have described as ideological state apparatuses. ${ }^{31}$ These imagined schools for women-children would ensure that they grew up to be properly interpellated into gendered positions. Even the son's interpretation of nunneries, which had previously offered young women an alternative to marriage, reformulates what had been a religious end into a means of producing particular kinds of 'women'.

The emphasis in prescriptive writing on making good women out of female children had an unintended consequence. As we have seen, it led to the dichotomising of girlish and womanly femininities, and Becon provides one of the clearest formulations of this contrast. The hybrid genre of his text arises from the use of religion to shore up existing gender hierarchies in early modern theories of social order. In order to entreat Protestant women of all ages to behave in womanly (that is, appropriately subordinate and chaste) ways, Becon self-consciously invokes a girl/woman dichotomy in his attempts to teach the self-regulation of female behaviour. The foremost concern in the section on 'The Office and Duty of Old and Ancient Women' is costly apparel, which the son claims ageing women use to offset their diminishing youth and beauty. Rather than 'decking and trimming' themselves with 'vain and light apparel', the son admonishes older women to dress modestly and deck themselves inwardly with a 'beautiful array of virtues': 
'For after this manner,' saith blessed Peter, 'in the old time did the holy women, which trusted in God, tire themselves.' Therefore the holy apostle, willing to bridle this foolish, vain, and carnal affection of trimming themselves in their old age, commandeth all sage and ancient matrons, that they, laying aside all light and girl-like apparel, array and tire themselves with such raiment as becometh the women that profess godliness. ${ }^{32}$

In a passage that is at once sexist and ageist, the son associates girlishness with frippery, covetousness and worldliness - all aspects frequently associated with the feminine but paradoxically constructed as unwomanly here. The ostensible concern about older women's (supposedly) excessive interest in material goods underscores a particular anxiety about the power that age might bestow upon women. An older woman's costly raiment would be problematic because it would enable her to exercise agency in the sexual economy via the material economy. As Karen Newman has shown, despite the fact that fashion was first and foremost a marker of class in early modern England, and despite the fact that men's dress was equally elaborate, sartorial extravagance could frequently be coded as feminine or effeminate. Particularly in Jacobean London, where a burgeoning merchant class and rapid influx of foreign goods were reconfiguring economic hierarchies, femininity was 'an available imaginary' through which writers could express anxieties about changing power dynamics. ${ }^{33}$

Becon's catechism, however, does not seem caught up in the kinds of contemporary economic anxieties of later urban pamphlets like Hic Mulier (1620) or Haec Vir (1620), ${ }^{34}$ and thus provides an interesting foil for texts in which femininity maps on to sartorial extravagance as a displacement for class anxiety, rather than as a direct expression of gender ideology. The son's association of worldliness with girlishness has wide-ranging implications for the category of girlhood. Material and erotic pursuits are unwomanly, and yet the construction of them as 'girl-like' implies that they are inherently feminine. This is, of course, the abiding paradox of traditional gender ideologies that construct women as innately susceptible to moral misdeeds even as they represent women as being the embodiment of morality. This classic virgin/whore dichotomy is transformed, however, when the two terms involved are woman/girl because these words are far more complex and multifaceted. If worldly pursuits are 'girl-like', then is there a time when they are appropriate? Is girlish behaviour forbidden in young female children, or only in mature women? What we have in Becon is the production of multiple femininities, the girlish and the womanly, the worldly and the spiritual, the unruly and the contained. The tension between girlhood as a time of life and girlhood as unruly behaviour opens up a space for 
negotiating female power and authority within the self-contradictory fissures of patriarchal ideology. Because definitions of girlhood as female childhood co-existed with definitions of girlishness as unruly femininity, the discourse of girlhood became a crucial tool for navigating the unstable demands of early modern gender norms.

Becon ultimately left unanswered the questions I've asked above, but other genres raised them in different ways and with different results. Writers like Gascoigne, Shakespeare, Middleton and Dekker picked up these questions when they shaped some of their most memorable female characters. But instead of seeking to move female children out of the untamed space of female youth, as the writers of conduct manuals and educational treatises did, these writers tapped into emerging discourses of girlhood to open up the question of whether it was in women's best interests to be 'womanly'. By designating adult female characters as 'girls', these three texts reconstituted womanly femininity not only as a learned performance, but also as a performance that adult women might refuse. These writers participated in a widespread cultural imagining of girlhood as a type of unruly femininity that existed in tension with definitions of girlhood as a time of life, and their 'girl' characters fragment categories of female identity, figuring the girlish as an action that a woman (or man or boy or girl) might play.

\section{II}

In the earliest of these texts, an almost identical formulation of Becon's girl/woman dichotomy appears. George Gascoigne published the novella The Adventures of Master F. J. in his miscellany-style collection of drama, poetry and prose entitled A Hundreth Sundrie Flowres (1573). Written to appeal to the same tastes as William Painter's Palace of Pleasure (1566), The Adventures of Master F. J. offered an original English story similar to the translations of short prose romances that were making their way into print in the late 1560 s and 1570 s. Unlike Painter, however, Gascoigne's prose incorporated self-conscious irony, and though it is not written in the mannered style of John Lyly's slightly later Euphues (1578), Gascoigne's use of framing devices highlight his awareness of the story's form as well as its content. Like Becon's Catechisme, Gascoigne's English novella defines girlishness as unruly female behaviour. But Gascoigne's dichotomy is less stable, and his text provides a rich example of the friction between these categories. Even as The Adventures of Master F. J. produces girlhood and womanhood as separate gender categories, it does so in ways that blur the distinctions 
between them and call into question the advantage of conforming to the type of feminine behaviour that moralists like Becon prescribed.

The Adventures of Master F. J. enacts, among other things, a complex comparison of the two types of femininity. G. T., the story's intrusive narrator, presents the main female characters as foils. F. J.'s married mistress Elinor and his virginal admirer Frances are kinswomen, and both are members of a northern English household at which F. J. is a guest. According to G. T., the similarities end there. F. J. falls in love with Elinor and attempts to woo her through letters and poetry; in the course of his courtly flirtations, F. J. piques the curiosity of Frances, who first becomes F. J.'s confidante by encouraging him in his pursuit of Elinor and then uses her position to enlighten F. J. about Elinor's past affairs. After detailing F. J.'s successful pursuit of Elinor and Frances's attempts to redirect his romantic attentions away from Elinor and towards herself, G. T. becomes anxious that Frances's behaviour may come across as jealous and manipulative. In defence of Frances, G. T. differentiates between the two equally beautiful rivals for F. J.'s affection by labelling one girlish and the other womanly:

[Lady Frances was] a virgin of rare chastitie, singular capacitie, notable modestie, and excellent beauty: and though F.J. had cast his affection on the other (being a married woman) yit was ther in their beauties no great difference: but in all other good giftes a wonderfull diversitie, as much as might be betwene constancie and flitting fantasie, betwene womanly countenaunce and girlish garishness, betwene hot dissimulation and temperate fidelitie. ${ }^{35}$

Pairing woman/girl with constancy/fantasy and fidelity/dissimulation, the narrator places womanly and girlish behaviour in opposition to each other. In G. T.'s formulation, womanly behaviour abjures girlishness, defining itself through a willingness to submit modestly and chastely to patriarchally sanctioned marriage. 'Girl' in turn is a placeholder category encompassing all that is considered unwomanly. Rather than being defined by age or marital status, girlhood here is a gender category defined by illicit female sexual desire.

Yet as much as the narrator would like to set womanliness and girlishness in opposition to each other, the woman/girl dichotomy breaks down. In my explication of G. T.'s passage, I maintain a consistent order among the paired terms to illustrate the conceptual distinction being made. The text itself does not, and the slippage suggests that the categories might not be as easily differentiated as the narrator would like. Having placed the positive, womanly traits first throughout, G. T. departs from this precedent in the final pair and places the negative, girlish trait of dissimulation before fidelity. Given the careful 
craftsmanship of Gascoigne's prose, the narrator's unconscious slip should not be attributed to authorial oversight. Rather, it reads like an intentional comment upon the intersections between the two categories and the two female characters. ${ }^{36}$ Until recently, critics have tended to take G. T.'s characterisations of Frances and Elinor at face value, casting Frances as an ideal of womanhood and Elinor as her moral opposite. In the past decade, however, several scholars have begun recognising that when read in the context of the rest of the text, many of Frances's actions could be described as 'hot dissimulation'. Steve Mentz has argued that the "etymology of "Frances," meaning "frank" or "honest," is ironic' because 'Frances is as duplicitous and witty as her corrupt companions' ${ }^{37}$ Susan Staub, on the other hand, emphasises the 'hot' part of Frances's character rather than her 'dissimulation'. She sees Frances, not Elinor, as the true unruly woman. As Staub astutely points out, Frances, though unmarried and declared a chaste virgin, clearly becomes titillated and turned on by watching F. J. and Elinor's sexual exploits. Frances lays claim to the usually masculine privilege of gazing at the object of her desire, Staub argues, whereas Elinor is content to be an object of desire for men. ${ }^{38}$ I would add that there is no concrete indication in The Adventures that Frances wants to marry F. J. rather than simply obtain him as her lover.

The contrast between Frances's marital aspirations and Elinor's adulterous actions were not made overt until Gascoigne reprinted his volume as The Posies of George Gascoigne two years later. In The Adventures of Master F. J., Frances never explicitly states that she wants to marry F. J.; she could, as far as the reader is concerned, simply want to be his lover. It is not until Gascoigne revised the tale that any mention gets made of Frances marrying him. In the retitled The Pleasant Fable of Ferdinando Jeronimi and Leonora de Valasco, translated out of the Italian riding tales of Bartello, ${ }^{39}$ Gascoigne recast the entire tale in light of Frances's father's desire to find a husband for her. The Lord invites Ferdinando (as the second version renames F. J.) to his house for the explicit purpose of promoting a marriage with his daughter Frances, who is briefly renamed Francischina before Gascoigne reverts to her English name. The text also initially renames Elinor with the Italian sobriquet Leonora, but also does not maintain the switch. ${ }^{40}$ Thinly disguising his original work as a translation and moving the setting to Florence, Gascoigne renamed the characters and eliminated the narrator G. T. Though the two women keep their English names, their narrative fates are different enough in the revised version to bear on our understanding of the text's construction of girlishness. In The Pleasant Fable we learn that Elinor continues undetected in her affair with her secretary, while Frances pines away 
and dies of a broken heart. Most critics agree that this move was an attempt to quell censorious responses to his first version, which was accused (falsely, if we believe Gascoigne) of being drawn from life. The Stationers' Company records have been lost for the year 1573, so whether the Court of High Commissioners actually banned the book is unclear; but Gascoigne's preface to The Posies indicates that the text was revised in response to criticism over the volume's dubious morality.

This later version actually has more radical implications for the relationship between girlhood and womanhood. The majority of critics prefer Master F. J. because it has a more complex authorial apparatus that configures the text as an exchange of letters presented through multiple layers of narration and, more importantly for my purposes, because they consider the original the 'less moralized version'. ${ }^{41}$ As a result, most editors choose to base their editions on Master F. J., including the alternative ending of The Pleasant Fable for comparison. ${ }^{42}$ Recent critics, however, have questioned the sincerity of Gascoigne's claim that he has 'gelded' his text of offensive passages as part of an overall personal reformation. ${ }^{43}$ Whether Gascoigne's claims of reform are genuine or feigned, the revised version does not produce the moral effects to which it lays claim.

At the heart of the controversy over the original version of the tale in The Adventures of Master F. J. was its lack of a moral conclusion. The risqué and transparently euphemistic descriptions of sex might have been less objectionable had they been followed by a suitably moralised ending. In the context of an early modern ethos that so clearly denigrated 'girlish' behaviour in women, Gascoigne's novella is remarkable precisely because Elinor's girlish actions do not lead to inevitable ruin. Her behaviour never gets exposed. The alternate ending of The Pleasant Fable heightens the distinctions between the two female characters, but in a way that punishes Frances for her womanliness and continues to let Elinor off the hook. Whereas in The Adventures of Master F. J. the future of its three main characters remains a mystery, The Pleasant Fable leaves the reader in no doubt as to what befalls them. Instead of concluding with F. J.'s final poem, the now-nameless narrator goes on to reveal that Ferdinando's experience with Elinor disillusions him so much that he abandons Frances, leaves the city of Florence and squanders the rest of his life in dissolute living:

he tooke his leave, \& (without pretence of returne) departed to his house in Venice: spending there ye rest of his dayes in a dissolute kind of lyfe: \& abandoning the worthy Lady Fraunces Chima, who (dayly being gauled with the griefe of his great ingratitude) dyd shortlye bring hir selfe into a miserable consumption: whereof (after three yeares languishing) shee dyed. ${ }^{44}$ 
Any moral drawn from such a passage is necessarily equivocal. The narrator is sympathetic to Ferdinando throughout the text, despite his pursuit of a married woman, and the text neither portrays his dissolute life as a punishment in itself nor reinforces such an interpretation through invoking religion or the possibility of punishment in the afterlife. Similarly, despite the narrator's condemnation of the 'girlish' Elinor/ Leonora, her affair with Ferdinando does not result in any tangible longterm consequences. Her husband never discovers the affair, and she continues on unrepentant. In the narrator's words, 'Notwithstanding al which occurements the Lady Elinor liued long in ye continuance of hir accustomed change. ${ }^{45}$ In contrast, Frances fares much worse. Ferdinando returns to Venice after Elinor rejects him in favour of her secretary, and his departure precipitates Frances's death. She loyally pines away for the absent Ferdinando. However much the narrator may praise Frances's womanly behaviour, it clearly comes with a price. The literary effect is not exactly one that would encourage female readers to pattern their behaviour on the 'womanly' Frances. This story, as G. T. admits at the end of the first version, is a 'thriftlesse History'. ${ }^{46}$ Excessive in its twists and turns, the text ends with no resolution. No marriage takes place, and it seems that no lesson has been learned by any of the people involved. Elinor is significantly 'unrepentant', to use Roy Erikson's word, and her lack of repentance was evidently shocking enough to some portion of its early modern audience to result in censure.

For us, the main misfortune that Elinor suffers as the result of her affair is the rape that G. T. describes using flippant innuendos in Master $F$. J., and modern readers are rightly disturbed by the trivialising way that G. T. describes the violent incident. As disturbing as the narrator's minimisation of Elinor's trauma may be, it is worth noting that G. T. does not represent the rape as a punishment for her affair. The narrator's dismissive attitude prevents the scene from being read as a moral parable of what happens to women who cuckold their husbands. Having gone to F. J.'s bed, Elinor finds herself accused (correctly) by her lover of also carrying on an extramarital affair with her secretary, and his jealousy provokes her angry denials. In retaliation and fury, F. J. forces himself on Elinor, and G. T. describes the rape as sexual combat. Having forgotten the courtesies of courtly love, F. J. 'drew upon his new-professed enemy and bare her up with such violence against the bolster that, before she could prepare the ward, he thrust her through both hands, and etc; whereby the dame, swooning for fear, was constrained for a time to abandon her body to the enemy's courtesy'. ${ }^{47}$ The narrator's deliberate omission of details and use of 'etc' position the reader with the swooning Elinor as equally unable to view the incident 
fully. Her abandonment is temporary, however, and the result of having been taken unprepared. She leaves the room swearing never to be taken 'at the like advantage' and finding 'her hurt to be nothing dangerous', and sleeps peacefully the rest of the night. Although G. T.'s refusal to acknowledge her rape as traumatic clearly participates in a misogynist enterprise, it is worth noting that Elinor makes good on her promise. She never submits to his sexual will again.

Moreover, the elimination of the rape scene in the second version leaves Elinor as having experienced no tangible consequences as a result of her illicit sexual behaviour. As such, her decision to leave Ferdinando and return to her secretary is not a function of any abuse, but the result of her sexual desire. In both versions, the narrator clearly tells us that the secretary's 'quils and pennes ... prick such faire large notes' that Ferdinando's/F. J.'s 'playne song' no longer appeals to her. With a less than subtle sexual innuendo, the narrator in the second version is left to attribute Elinor's change of heart almost exclusively to Ferdinando's sexual inadequacies. In contrast, Frances languishes over Ferdinando and pays with her life for her unwillingness to change her affections. Susan Staub has read Frances's death as a punishment for being an unruly woman. While I agree with Staub that the second version tames Frances, I read her death as a consequence of her having been tamed rather than the means of taming her. Her death results from playing the woman in a world that does not necessarily reward such behaviour even as it insists upon it.

The split between girlish and womanly behaviour typified by Elinor and Frances is crucially one between two types of femininity. Neither Elinor nor Frances directly engages in what Judith Halberstam describes as female masculinity. ${ }^{48}$ Unlike the two 'girl' characters I will be examining next, Elinor and Frances do not cross-dress, and Gascoigne does not characterise their behaviour as masculine. In so far as their actions challenge the patriarchal order, they do so from within subject positions that are explicitly feminised. The girlish traits exhibited by Elinor, and to a lesser extent by Frances, are those frequently ascribed as proper to, though undesirable in, female human beings. Girlishness here is performative, but also squarely located in stable feminine subject positions. In contrast, Joan la Pucelle in The First Part of Henry the Sixth and Moll Frith in Middleton and Dekker's The Roaring Girl engage in pursuits coded as 'masculine' within the texts in which they appear. In both these cases, their categorisations as 'girls' call into question the epistemological and ontological status of gender. On the early modern stage, where boys played female characters, female identities would necessarily have been performative, but so too would male identities, and these 
cross-dressing female characters queried how and whether early modern audiences could know the differences between 'men' and 'women'. Both these plays associate girlishness with movement between gender identities, and the characters deploy the discourse of girlhood less to mark specific sets of behaviours and more to identify female transgression itself.

Although Joan's sexuality in 1 Henry VI has been generatively explored in feminist criticism, the connections between the play's representation of Joan and early modern discourses of girlhood have remained a footnote. Joan's connection to the category of the 'girl' lies in a textual crux from the trial scene of 5.6, when the Duke of York condemns her to be burned at the stake as a sorceress. Joan initially rebukes her English accusers, but when she realises that they will not yield, she attempts to postpone her execution by claiming to be pregnant. By 'pleading the belly', Joan should have been granted a temporary reprieve under English law, and, according to the chronicles, the historical Joan did in fact receive a nine-month stay of execution. Within the play, however, her strategy backfires because her supposed pregnancy only makes the English more determined to kill her. Assuming that the Dauphin is the father of the child, Warwick insists that the English will not let the 'bastard' live (5.6.70). Joan tries to improvise a new strategy to save her life, denying that the Dauphin has fathered the child. She claims first that Alençon is the father, and when the English still deny her mercy, she moves on to claim René, King of Naples, as the father. Upon hearing Joan name a third man as a potential father for her child, and by extension confessing to having had three sexual partners, York makes a statement that redefines Joan. He declares, 'Why, here's a girl' (5.6.80). Editors traditionally gloss over this line, either skipping it altogether or annotating 'girl' as 'wench', as if the substitution offered an adequate explanation. By 'girling' Joan, York recategorises her as not a 'maid' but a 'girl', a move that invokes connotations of sexual transgression and, more importantly, sexual transgression matched with a threat to social and political hierarchies.

Shakespeare's Joan brings the question of girlishness into the realm of the history play, a genre concerned, as Jean E. Howard and Phyllis Rackin note, with 'an aristocratic world where patriarchal domination is assumed and female characters marginalized'. ${ }^{49}$ As they point out, the subject of history plays is 'the difficult transmission of patrilineal authority from one generation to the next'. ${ }^{50}$ Women, particularly in Shakespeare's first tetralogy, haunt the margins of chronicle histories as potential disruptive forces and reproductive conduits, but they do not take centre stage because the main characters are kings and fathers, 
princes and sons. Simply forcing her way into the masculine space of political history makes Joan a transgressive figure; for her to do it as a peasant girl makes it doubly so. Through most of 1 Henry VI the male characters express anxieties about Joan's cross-dressing and classcrossing, but in the trial scene the threat that Joan poses to patrilineal authority comes in the specific form of her reproductive capacity. Her pregnancy could provide the Dauphin with an heir, thereby prolonging the military conflict between the French and the English. Joan poses more than just a symbolic threat by crossing categorical boundaries; her sexual incontinence could disrupt English political ambitions. Unlike Shakespeare's cross-dressing comic heroines, whose masculine attire has often been read as gesturing back to the body of the boy beneath the costume, the revelation of Joan's pregnancy points not to the literal male body on stage but to Joan's imagined female body, and it is her fictional female body that poses the greatest threat to her English male accusers.

The play never makes clear whether the audience believes that Joan's pregnancy is fact or fiction; instead, Joan's purported pregnancy underscores her hypocrisy and undermines her claims of virginity. Diverging from the historical record, including the politicised English histories that Shakespeare would have read, this scene leaves open the imaginative conflation of Joan's politics with sexual promiscuity. Theodora Jankowski has suggested that the goal of dramatising Joan's sexual incontinence was to undo her historical position as a 'queer virgin', which she defines as 'women who chose to resist incorporation into the sex/gender system as sexually active women by retaining their virginity beyond its "transitional phase" well into adulthood'. ${ }^{51}$ That is, queer virgins "are those who confound the sex/gender system not by trying to be men, but by not being "women". ${ }^{52}$ Joan does exactly this but, as Jankowski acknowledges, not as a queer virgin. I would argue that the category of the 'girl', a different but equally unruly female category, best accounts for Joan's position and sheds significant light on York's comment. The play only fully articulates Joan's status as a 'girl' with the revelation that an unruly female body underpins her female masculinity. Though she is initially threatening because she is a French female character who wears armour and leads an army, the trial scene reveals that Joan's reproductive capacities, not her masculinity, pose the greatest threat to her male English accusers. I want to suggest that Joan's girlishness helps to deconstruct the masculine/feminine binary in ways that render both terms virtually empty of meaning. Unlike Gascoigne's prose novella, where two separate characters epitomise the dichotomy between girlish and womanly femininities, Shakespeare's play portrays Joan as acting out multiple female identities herself. She is a chaste 
French peasant maid, a martial masculine warrior and a demonic whore all rolled into one, and this combination ultimately culminates in her explicit identification as a 'girl'.

Unlike Gascoigne, Shakespeare establishes Joan's identity as a 'girl' less in opposition to womanhood than in opposition to maidenhood. Through most of the play, Joan is associated with virginity in her own speech and that of the other characters. From the Bastard of Orleans's first mention of Joan as a 'holy maid' (1.3.30), Joan is remarkable not only because of her youth (she is only eighteen) but because of the combination of her lower-class status, chastity, martial prowess and French nationality. The construction of her femininity is inseparable from all of these, which combine to place her outside of the category 'woman'. She exceeds her sex, as Joan claims in Act 1, Scene 3, and yet she positions herself explicitly in the feminine subject position of 'maid'. Calling attention to her lower-class origins as a shepherd's daughter when she first encounters the Dauphin, Joan uses class-inflected language to describe her body as transformed physically through her heavenly vision of the Virgin Mary:

Lo, whilst I waited on my tender lambs,

And to sun's parching heat displayed my cheeks,

God's mother deignèd to appear to me,

And in a vision, full of majesty,

Willed me to leave my base vocation

And free my country from calamity.

Her aid she promised, and assured success.

In complete glory she revealed herself-

And whereas I was black and swart before,

With those clear rays which she infused on me

That beauty am I blest with, which you may see.

Ask me what question thou canst possible,

And I will answer unpremeditated.

My courage try by combat, if thou dar'st, And thou shalt find that I exceed my sex.

Resolve on this: thou shalt be fortunate,

If thou receive me for thy warlike mate.

Joan's own self-fashioning figures her masculine attire and strength as proceeding from her identity as a martial maid and as the Virgin Mary's particular emissary. Joan describes her transformation from peasant to prophet as bodily, as a bleaching of her 'black and swart' skin through the light of the virgin, who infuses Joan with her glory and chastity. Along with this elevation of class comes the endowment of a certain paradoxical amount of physical strength; although a maid, Joan claims 
the position of 'warlike mate', and she bests the Dauphin in one-on-one combat. To be sure, she locates her strength in her divine mission, but she also attributes it to a female lineage, claiming that 'Christ's mother helps me, else I were too weak' (1.3.85). She represents her transformation as bodily as well as spiritual, and in many ways ongoing; her continued relationship to the Virgin Mary produces physical effects that enable her to perform feats of strength and go beyond her biological capacities. Joan's speech represents her prophetic maidenhood as a contingent state of being, one located at the nexus of the social and the supernatural.

For the same reasons that Joan exceeds the category of 'woman', the other characters call into question her location in the category of 'maid'. The English characters cast doubt on Joan's sexual continence because her contingent female identity enables her to cross-dress, fight in battles and intervene in political affairs. ${ }^{53}$ When, for example, Bedford asks who the 'Pucelle' is 'whom they term so pure', Talbot replies doubtfully, 'A maid, they say' (2.1.20-1). By adding the qualifying phrase 'they say', Talbot expresses scepticism about whether such a name can properly be attributed to Joan. Bedford's response likewise expresses disbelief that a virgin can engage in military activities. 'A maid?' he questions, 'And be so martial?' (2.1.22). Rather than prompting the Englishmen to question their assumptions about masculinity and femininity, Joan's behaviour calls her chastity into question. The name of whore always seems to haunt the name of virgin in this play, a connection already embedded in the pun on 'pussell'. Talbot invokes this pun when he first hears of 'Joan la Pucelle': 'Pucelle or pussel, Dolphin or dogfish, / Your hearts I'll stamp out with my horse's heels' (1.4.107-8). Playing on the homophone between the French pucelle, virgin, and the English 'pussell', or strumpet, Talbot also recalls the other homophonic connection between 'pussell' and the female genitals, equating Joan with her sexual organs in the way that the virgin/whore dichotomy often does.

As a term and gender category, the word 'girl' mediates between the categories of the virgin and the whore, potentially signifying both and eliciting the epistemological problem of sexual knowledge. Shakespeare's representation of Joan raises the question of how a virgin can be distinguished from a whore, and throughout most of the play the answer is that she can't. To make such a distinction visually possible, the play dramatises Joan's role as a 'girl' by spectacularly staging a group of devils forsaking her. For an English audience, Joan's purity would already have been doubtful as a matter of course. When she boldly states, 'Assigned am I to be the English scourge' (1.3.108), it would not have gone over well. The term 'scourge' would have linked her with figures like Christopher Marlowe's Tamburlaine, making her 
heroic yet despicable, possibly a divine instrument but nonetheless demonic. ${ }^{54}$ As a scourge, Joan might very well be acknowledged to have God's sanction to punish the English for their sins, but since God was thought only to use souls who were already damned as scourges, such a claim would have placed Joan's own salvation in doubt. Significantly, Joan never repents or recants. She exits to her execution cursing the English, hoping that the sun will never shine upon their country and telling them to go hang themselves. She is, in the language of Calvinism, reprobrate.

Indeed, anxieties about Joan's gender ambiguities cut across national boundaries in 1 Henry VI. Although the play at times views the danger of Joan's sexuality as nationally inflected and a feature of her French identity, the French men express equal scepticism about her ability to be both martial and a maid. Just as the English characters instinctively distrust Joan's status as a virgin, the French courtiers respond to her female masculinity with a series of bawdy puns. Introduced in Act 1 as a 'holy maid' sent to 'drive the English forth', Joan overcomes two challenges designed to test the veracity of her prophecies (1.3.30; 1.3.33). Recognising that Charles has sent René in his stead, Joan insists on a private conference with the true Dauphin. While Joan engages in oneon-one combat with Charles (proving herself by defeating him), René, Alençon and the Bastard of Orleans look on and voice insinuations. The phallic interplay, combined with the Dauphin's subsequent propositioning of Joan, would be enough to cast doubt on Joan's claim that she 'must not yield to any rites of love' (1.3.92-3). As a self-avowed virgin outside the confines of a nunnery on a Protestant stage, Joan would have been undermined even without the play's staging of her martial feats. The play simply reinforces the dramatic spectacle's sexual overtones through the comments of the French courtiers. In response to René's observation that the conference has gone on for a considerable amount of time, Alençon remarks, 'Doubtless he shrives this woman to her smock, / Else ne'er could he so long protract her speech' (1.3.98-9). Intimating that the Dauphin has begun the process of undressing Joan eliciting Protestant accusations about the misbehaviour of priests during confession - Alençon goes on to associate women in general with sexual seduction. 'These women', he says, 'are shrewd tempters with their tongues' (1.3.102). Even though Joan's virginity serves the interests of the French, they, like the English, cannot quite imagine a form of female identity that would allow for masculine behaviour without relegating it to the category of the 'whore'.

The doubts of Joan's fellow characters prepare the audience for the piece-by-piece dismantling of her self-fashioned identity. The trial scene 
undoes Joan's previous self-construction as 'maid' and identifies her as a 'girl', but it also exposes the unviability of femininity and femaleness in the world of Shakespeare's history plays. As Joan invokes one defence after another, each based upon a protected class of female identity, she discovers no refuge, and no mercy; no form of femininity will save her from being burned as a witch. She begins by forsaking her shepherd father and denying her parentage, claiming instead to be descended from royalty in preparation for her first line of defence against being burnt as a witch - where she claims protection as the descendent of kings. The scene turns upon Joan's refusal of her status as peasant 'girl' - the Shepherd calls her 'my girl' (5.6.25) - and the way that it reveals her to be an unruly, sexually unchaste 'girl', unworthy of her father's blessing and worthy to be executed in the most painful way possible. Having previously described herself as a shepherdess, Joan now styles herself as noble, as if her vision of the Virgin Mary has entirely erased her biological origins and given her a claim to a new lineage. Insulting the Shepherd by calling him a 'base ignoble wretch' and claiming 'gentler blood', Joan orders him away and accuses the English of producing the man to impersonate her father to cast doubt upon her royal descent. For Warwick and York, however, her statement only casts further doubt upon her virtue, since it shows her to be an ungrateful child who is willing to impugn her mother's virtue, since if the Shepherd is not her father, it makes her a bastard. The Shepherd, in turn, renounces Joan, calling her a 'drab' who deserves to have sucked 'ratsbane' at her mother's teat or to have been eaten by a wolf in her infancy.

The reason that Joan refuses to acknowledge the shepherd as her father is precisely because she hopes to link her current status to the sexual innocence of infancy. In her initial defence, Joan attempts to capitalise on her virginity, declaring:

Joan of Arc hath been

A virgin from her tender infancy,

Chaste and immaculate in very thought,

Whose maiden-blood thus rigorously effused,

Will cry for vengeance at the gates of heaven.

As Theodora Jankowski points out, the historical Joan of Arc's virginity prevented her from being condemned as a witch; though burned at the stake, Joan of Arc was crucially not burned for witchcraft because it was believed that a virgin could not be a witch. ${ }^{55}$ In Shakespeare's play, however, Joan's status as a virgin does not exculpate her, since the audience has already seen her communing with devils and since the only 
reprieve offered in recompense for her virginity is a faster-burning fire that would kill her with less pain than a slow-burning one.

Significantly, it is only when the special status of Joan's virginity fails as a defence that she turns to motherhood and pregnancy. In this play, virginity, real or dissembled, does not exempt a female character from punishments for transgressing the gendered boundaries of politics and war. As in Master F. J., the contained feminine position offers no practical advantage. With the failure of her virginal power, Joan turns to motherhood as a means of claiming a special legal status, but, as we have seen, this too backfires. She finds no mercy. Having been written out of the role of virgin, Joan embraces her girlhood, and leaves the stage cursing the English. The female sexuality lurking behind her masculine actions ultimately makes her more dangerous and anxiety-provoking than masculinity alone. Whereas Gascoigne's tale did not represent girlish behaviour as resulting in negative consequences, Shakespeare's play makes clear that inhabiting the category of the 'girl' brought with it the promise of power but also the threat of punishment. As important as it is to recognise that 'girlish' behaviour could facilitate sexual and social transgressions, it could also sometimes be severely punished. Elinor's girlishness goes unpunished because it remains invisible, whereas the public and spectacular nature of Joan's performative girlhood prompts the mechanisms of the repressive state apparatus to destroy her. Shakespeare roots Joan in a masculine world in which womanly femininity does not seem to exist, and no alternative female exemplum appears. If being constituted as a socially viable being requires recognition, that very recognition carries dangers and consequences. As Judith Butler points out, 'There are advantages to remaining less than intelligible, if intelligibility is understood as that which is produced as a consequence of recognition according to prevailing social norms. ${ }^{56}$ Joan attempts to claim recognition within prevailing norms, and finds no space within which to lead a livable life. Being a French female seems to be enough to make her reprobate.

III

Joan is nonetheless a dramatically compelling character, and for all the play's condemnation, she seems importantly to be an even more disruptive girl than Elinor. Elinor may provoke anxiety, but Joan produces powerful effects within the play and on the stage. In both The Adventures of Master F. J. and 1 Henry VI, girlishness can only be sustained when it is hidden and undiscovered (at least within the diegetic 
framework). Once detected in the former, Gascoigne's narrator hints that his female readers should condemn it and eschew such behaviour themselves, and once detected in the latter, repressive state apparatuses swing into action and try to destroy it. The dramatic reality of execution in 1 Henry VI becomes a linguistic trace in Thomas Middleton and Thomas Dekker's play The Roaring Girl. The language of death and hanging haunts Sir Alexander Wengrave's threats against the roaring girl, Moll Cutpurse. The real-life cross-dresser Mary Frith whose notoriety inspired the play eventually faced punishment in Bridewell, but the festive tone of Middleton and Dekker's drama overshadows the potential dangers of early modern girlhood. The play represents Moll's critics as the ones needing to undergo a personal transformation to appreciate her worth. Unlike Gascoigne's tale, which criticises girlish behaviour even as it represents the potential drawbacks of womanly behaviour, and unlike 1 Henry VI, which punishes Joan's unwomanly actions, The Roaring Girl embraces Moll Cutpurse's girlish eccentricities.

Mary Frith in both her fictional and historical guises has proven as fascinating for contemporary scholars as she was for Renaissance readers and audiences. Having enjoyed critical popularity since the late 1980s, The Roaring Girl and the life of the historical personage of Mary Frith have received attention from critics who have categorised Moll as a transvestite, an hermaphrodite, a masculine woman and a male actor. ${ }^{57}$ As a female character engaging in masculine behaviour and wearing men's clothing, Moll systematically defies classification, to the dismay and sometimes to the delight of her fellow characters. As Sir Alexander complains, 'One knows not how to name' her (1.2.129). The closest the play comes, it seems, is to label her a roaring 'girl', a terminological choice that makes sense in light of the cultural association between girlhood and transgression in the early seventeenth century. ${ }^{58}$ The initial debate about the play centred around whether Moll's cross-dressing subverted or reinforced the existing social order, although more recent criticism has focused on the play's class politics, representations of criminality, and its urban setting. ${ }^{59} \mathrm{My}$ own reading of the play suggests that the potential for agency opened up by the discourse of girlhood had a complicated relationship to the ability of actual female human beings to exercise power within early modern society.

In the face of a prevailing ideology that sought to root out girlhood and transform it into womanhood, Middleton and Dekker enable Moll to act like a girl openly on the stage. I want to use the character of Moll to demonstrate the way that constructions of girlishness as a model of femininity were contextually specific. 'Girlhood' throughout early modern culture seems to have carried connotations of unruliness and 
transgressive behaviour, but the forms that the girls' transgressions took were particular and varied according to class, genre, place and historical moment. For a contemporary feminist, using girlhood to fragment the category of 'women' carries with it the risk of reifying 'girls', as if 'girlhood' were a stable, uncontested category out of which 'womanhood' could be formulated. By putting The Roaring Girl side by side with The Adventures of Master F. J. and 1 Henry VI, we can see that not all girl characters in early modern literature looked alike. The discourse of girlhood could describe Italian adulteresses, martial French maids or London cross-dressers; 'girls' might be demonic or virtuous, whorish or chaste. If girlhood was a way to figure masculinities and femininities as socially coded behaviours rather than biological essences (as doings rather than beings), the behaviours grouped under those categories were contested and shifting.

With this Jacobean city comedy, we see a significant departure from the two previous Elizabethan texts. The Roaring Girl takes us from the aristocratic battlefields of the history play to the hustle and bustle of merchant-class London, with citizen wives, destitute landed gentry and canting thieves. Portraying an urban environment and writing after the late Elizabethan vogue for cross-dressed heroines in comedies, Middleton and Dekker were more likely to represent Moll's crossdressing in a sympathetic light. Like Joan, Moll Cutpurse's girlishness relates to her performance of masculinity; she dresses in men's apparel, smokes tobacco, engages in swordplay and cants with local thieves, and this brand of female masculinity marks her as a member of London's youth culture. As Stephen Orgel points out, the roaring girl offers the female complement to the roaring boy, the aristocratic son who frequents taverns, squanders money and causes general social upheaval. For Orgel, Moll becomes doubly subversive because she changes not only gender roles but also class positions as she assumes the habit and financial privileges of a man with money. ${ }^{60}$ The roaring boy, on the other hand, would generally be associated with his dependence on a father, like the character of the prodigal son Jack Dapper in the play. In contrast, Moll is financially independent and unapprenticed. Oddly enough, the thief Trapdoor is the person who most explicitly lays claim to the title of 'roaring boy', declaring that as a 'roaring boy' he will be the one to 'put[] down' the 'Roaring Girl' (1.2.248). ${ }^{61}$ This pairing of roaring boys and girls, via prodigal sons and thieves, is symptomatic of the general association between youth and rebellion in early modern English culture. Disorderly behaviour was not associated just with roarers, but with youth more broadly, as can be seen clearly in a remark made by Jack Dapper's page Gull. Disappointed with the three half- 
pence allowance that his master gives him for his meal, Gull complains that his master has spent three pounds the night before 'amongst girls and brave bawdy-house boys' (2.1.129). Even when the speaker dispenses with the modifier 'roaring', 'girls' and 'boys' were unruly figures in Jacobean London.

Within the play, nobody succeeds in putting down Moll, and her triumph lies in her ability to be translated between multiple gender identities, not only 'girl' but also 'woman' and 'man'. The central romantic plot of the play revolves around the engagement of Mary Fitzallard and Sebastian Wengrave. Because Sebastian's father Sir Alexander Wengrave disapproves of the match, Sebastian devises a scheme to convince his father that he has transferred his affection from Mary to Moll Cutpurse, the Roaring Girl. The plan hinges on the assumption that his father will be so grateful when his son agrees not to marry a transvestite that he will consent to the original marriage, and the plan ultimately succeeds at the end of the play after Sebastian enlists Moll's help. In the end, Sebastian and Mary obtain Sir Alexander's consent, and Sir Alexander comes to respect and appreciate Moll Cutpurse's virtues. But along the way he acts as her harshest critic, and he and the other characters voice anxieties about the way she disrupts gender and social categories.

The failure of gender categories to account for Moll typifies her particular form of girlishness. The 'girling' of Moll within the play depends not on age or dependency but on her exhibition of a particular kind of gendered behaviour, one linked inextricably to the world of Jacobean city comedy, a world of urban youth culture where Moll is specifically a roaring girl and not a roaring woman. Moll shows us 'girlishness' as resistance to fixed gender categories; that is, girlhood in this play is not associated with a set of behaviours, so much as transgression and transformation itself. Moll has a way of making gendered terms look like sets of behaviours that do not necessarily have to be organised into separate binaries, calling social and cultural hierarchies into question. The other characters constantly attempt to categorise Moll and stabilise her identity, but their labels keep shifting. In the words of the citizen wife Mistress Gallipot, 'Some will not stick to say she's a man, and some both man and woman' (2.1.209-11). Her fellow characters can never settle on a single label. Moll 'will not stick to' one of the usual gender categories used to classify adults as men and women, causing no end of frustration and excitement. Her hybrid gender identity - highlighted by her initial appearance in a frieze jerkin and a black woman's safeguard - makes her not a man and not a woman, leading Sir Alexander to view her as inhuman - 'a creature' that 'nature hath brought forth / To mock the sex of woman' (1.2.127-8). I would suggest that she does exactly 
that: she mocks the idea that there is a stable, monolithic category of 'woman' that can be constructed out of the multiple lived relations of female characters in the play.

Others have explored Moll's sexuality, but I am less interested in her erotic potential than in her social location within the landscape of Jacobean London. The play self-consciously positions her outside the categories of 'maid' and 'wife'. She plays an alternative female role located somewhere between the marriageable maid Mary Fitzallard and the already married citizen wives but outside of a marital trajectory. The costuming, plot and language all conspire to set up Mary and Moll as dramatic foils. The two characters share a name (Sebastian calls Mary by the nickname 'Moll' in the first scene), and the feigned substitution of the roaring girl for the 'sweet maid' in Sebastian's affections furthers the connection (1.1.178). Mary, like Moll, changes her clothing several times during the play, appearing first as a seamstress and then crossdressed and disguised as a page in order to fool Sir Alexander. The pretend substitution of Moll for Mary during the wedding scene puts the final touch on a series of events designed to provoke comparisons and contrasts between the two unmarried female characters. It can be tempting in the face of Moll's charisma to dismiss Mary Fitzallard as a pale, feminine shadow of a character, but Mary displays a certain amount of assertiveness in her own right. Her adoption of various disguises in order to achieve her goals prevents her from being a mere pawn in her marriage negotiations; indeed, her father plays a rather cursory role in the affair and in the play in general. The other characters do consistently refer to her as a 'damsel' or 'maid', which sets her against Moll, the play's 'girl' or 'wench'. Whereas Mary lives under the authority of her father, Moll has no father; whereas Mary cross-dresses as a disguise, Moll cross-dresses as herself; whereas Mary's disruption of gender boundaries occurs in the service of securing the position of wife, Moll's is in the service of remaining single. Although Moll consents to help orchestrate the marriage of Mary and Sebastian, she rejects marriage for herself and instead embraces the single life. 'I have the head now of myself,' she says, 'and am man enough for a woman' (2.2.42-3). Rather than give up the freedom of her girlish identity, Moll chooses to remain unmarried, and in fact offers a biting critique of the institution of marriage: 'Marriage is but a chopping and changing, where a maiden loses one head, and has a worse i'th' place' (2.2.43-4). To keep her own head, Moll risks the potential dangers of being a single girl and resists becoming a marriageable maiden.

Why then does Moll help bring about the marriage of Sebastian and Mary? Moll claims to have 'pitied' Mary 'for name's sake, that a Moll / 
Should be so crossed in love' (4.1.66-7). As Jean E. Howard points out, the generic conventions of comedy demand that the play end in marriage, but while the play gives us a marriage between a Mary and a man, that Mary is not the Roaring Girl. ${ }^{62}$ What seems particularly subversive about The Roaring Girl is that it gives us both Mary and Moll and refuses to choose between them; Moll's particular brand of masculine femininity or feminine masculinity encompasses female solidarity, and the play suggests that multiple kinds of gender identities can and should be socially viable. Moll's objection to marriage is not to marriage per se, but the social reality of marital power relations in her world. Her speeches recognise the material constraints within which women function in her society, and Moll seeks to open up, rather than close down, options for other female characters. The play ultimately teaches the characters, and through them the audience, to appreciate Moll's singularity. The character Moll also has a lesson to teach contemporary feminist scholars about there being space for two female characters in a play worthy of feminist analysis. Moll as a character explicitly insists that her girlish behaviour, though admirable, is not the only viable female identity.

Initially heralded as a revolutionary figure, however, Moll has come to be viewed as less disruptive than once thought. Critics like Jane Baston and Deborah Jacobs argue that the play renders Moll unthreatening by portraying her girlishness as paradoxically maintaining the existing social order. ${ }^{63}$ Instead of being a criminal, Moll helps bring criminals to justice; instead of being sexually incontinent, Moll maintains her chastity and punishes men who would make women their fond, flexible whores. For a critic like Baston, the positive portrayal of Moll Cutpurse as an upholder of social order ultimately undoes her challenge to the social hierarchy. She laments that by the end of the play Moll can be 'dismissed as a "good wench" ... a description that subsumes Moll into existing class and gender hierarchies and so ensures her rehabilitation into the existing patriarchy'. In response to the playwrights' claims that they have made Moll better in the play than in nature, Baston asks, 'For whom is Moll's reformation better?' 64 In response to Baston's query, Alicia Tomlinson has written that she believes 'the playwrights would answer, better for Moll'. She argues that the fictional image of Moll would have helped the real-life roaring girl to craft 'her public persona and use[] her celebrity to wield power' because the play 'celebrates her reputations and disparages rumor, validating Moll as an expert of the underworld while denying her participation in its crime'. ${ }^{65}$ I would add that these paradoxes effectively undo the fixity of gender binaries and blur the distinctions between the criminal and the legal, the sexual 
and the chaste, the manly and the womanly. What is most important for my argument is that Moll, like girlhood in general, denaturalises these categories and makes them socially and culturally contingent. She not only disrupts any easy alignment between biological sex and gendered behaviour, she undoes the stability of gender as a fixed category and turns it into a contingent, relational position. As Kate Bornstein describes it in Gender Outlaw, the desire for transsexuality for some involves the desire for transformation itself, and I would analogise Moll's description of herself as a desire for a continual state of transformation. ${ }^{66}$

Whether or not Moll's portrayal on the Fortune stage ultimately subverts the social order as a whole, it argues against a social mandate of gender uniformity. As the Prologue makes clear in its taxonomy of the 'tribe' of roaring girls, there is more than one way to act like a girl:

I see attention sets wide ope her gates

Of hearing, and with covetous listening waits

To know what girl this roaring girl should be-

For of that tribe are many. One is she

That roars at midnight in deep tavern bowls,

That beats the watch, and constables controls;

Another roars i'the' day-time, swears, stabs, gives braves,

Yet sells her soul to the lust of fools and slaves:

Both these are suburb-roarers. Then there's besides

A civil, city-roaring girl, whose pride,

Feasting, and riding, shakes her husband's state,

And leaves him roaring through an iron grate.

None of these roaring girls is ours: she flies

With wings more lofty. Thus her character lies-

(Prologue 13-26)

By further splintering the category of femininity and imagining multiple types of roaring girls, the prologue presents girlishness as a set of performed behaviours rather than innate impulses. One girl may carouse in taverns at night and physically abuse the constables; another may provoke unrest through prostitution; while still another city-dwelling girl may land her husband in debtors' prison through extravagant expenditures. Moll is none of these; she is a superior roaring girl. Middleton and Dekker's dramatic defence of Moll intervenes in contemporary debates about femininity and describes girlishness as a set of performative choices. Moll consciously chooses to act like a roaring girl, and she chooses to act like a particular type of roaring girl. This passage suggests that girls like Moll fly with loftier wings than those who allow themselves to be defined as womanly or unwomanly. Thus The Roaring Girl renders girlhood sustainable as well as desirable. In some ways, a text like The Roaring Girl seems to provide an imaginative if cursory 
early modern answer to Judith Butler's question about what makes a life livable. In Undoing Gender, Butler distinguishes between a 'minimal biological form of living' necessary to sustain life and the kind of livable life that enables people to be endowed with human rights. She writes, 'In the same way that a life for which no categories of recognition exist is not a livable life, so a life for which those categories constitute unlivable constraint is not an acceptable option.' For Butler, to 'minimize the possibility' of people living 'unbearable' lives, we need to stop 'legislating for all lives what is livable only for some, and similarly, to refrain from proscribing for all lives what is unlivable for some' ${ }^{67}$ The social recognition of Moll's identity as viable undoes the insistence that we saw from the mother in the jest with which this chapter began that the female sex enjoins only one kind of behaviour. As such, the play takes a small step toward expanding the kinds of lives acknowledged as human.

Whether or not actual early modern women found access to transgressive girlhood to be empowering is a more difficult question. The real-life Mary Frith certainly gained notoriety and may, as Tomlinson suggests, have been able to take advantage of her fame. But her girlish behaviour also got her into legal trouble. A now-infamous entry in the Consistory Court of London Correction Book reveals that Mary Frith's unruliness resulted in her being forced to do penance at Paul's Cross:

This day \& place the said Mary appeared personally \& then $\&$ there voluntarily confessed that she had long frequented all or most of the disorderly $\&$ licentious places in this City as namely she hath usually in the habit of a man resorted to alehouses, taverns, tobacco shops $\&$ also to playhouses, there to see plays $\&$ prizes $\&$ namely being at a play about 3 quarters of a year since at the Fortune in man's apparel $\&$ in her boots $\&$ with a sword by her side, she told the company there present that she thought many of them were of the opinion that she was a man, but if any of them would come to her lodging they should find that she is a woman $\&$ some other immodest $\&$ lascivious speeches she also used at that time. And also sat there upon the stage in the public view of all the people there present in man's apparel \& played upon her lute $\&$ sang a song. ${ }^{68}$

Critics have debated exactly what happened when Mary Frith took the stage, ${ }^{69}$ but while it might be titillating to imagine that she might have played herself, what does seem clear is that at some point after the play was written, Mary Frith ended up in Bridewell and was only released after confessing to licentiousness, declaring herself 'heartily sorry' for her actions and promising to behave 'honestly, soberly, \& womanly' in the future. That promise to behave 'womanly' resonates quite strongly as a pledge to give up her girlish ways, but she did, however, insist that she had never been a bawd nor been 'dishonest of her body'. And yet 
even with an historical source such as the Correction Book it is hard to separate the real Mary Frith out from her performance, since a letter from John Chamberlain dated 11 February 1611 (Old Style) casts doubt on her sincerity. Chamberlain writes:

This last Sunday Moll Cutpurse, a notorious baggage, that used to go in man's apparel, and challenged the field of diverse gallants was brought to the same place [Paul's Cross], where she wept bitterly and seemed very penitent; but it is since doubted she was maudlin drunk, being discovered to have tippel'd of three quarts of sack before she came to her penance. ${ }^{70}$

While it is gratifying from a modern perspective to think of Moll refusing to capitulate and repent, such behaviour could have brought about her demise. It is important to remember that girlish behaviour, for all that it may have conferred agency on fictional characters, could bring about real, negative consequences.

In practice, early modern women would not have been entirely in control over their status as girls. In most cases, their gendered position would have required that they negotiate with existing ideologies using similar techniques to those that Ann Rosalind Jones describes in her study of early modern women poets. Adapting the three 'viewer' positions that Stuart Hall has defined as being available in contemporary media, Jones describes the relationship between women writers and the dominant tradition as engaging with imitation, negotiation and appropriation. Imitation, defined as the adoption of a 'dominant/hegemonic' position, involves 'receiv[ing] and reproduc[ing] a public text obediently'. ${ }^{71}$ To attempt to become the ideal woman described in Vives, for example, would be to attempt imitation. Appropriation, on the other hand, amounts to outright rejection of those standards; it entails taking 'an oppositional position from which the ideological message and force of the reigning code is rearticulated, that is, pulled out of its dominant frame of reference and subversively inserted into an "alternative frame of reference"'. ${ }^{72}$ The girl in the jest with which I began this chapter offers perhaps the best example of girlish appropriation that I have found with her jest that men should, in fact, be subordinate to women. Dekker and Middleton's positive portrayal of Moll, on the other hand, seeks to negotiate a position for female agency within existing social constructions of gender. A negotiated position is, in Jones's words, 'one that accepts the dominant ideology encoded into a text but particularizes and transforms it in the service of a different group' ${ }^{73}$ That is to say, negotiation holds together the oppositions inherent in competing definitions of femininity and dramatises the push and pull between them.

What all three of the texts I have been examining have in common 
is that they make it impossible to uphold a simple masculine/feminine binary. The construction of girlhood in these texts provides a discursive apparatus for imagining femininities as multiple and contingent, rather than singular or innate. If Gascoigne and Shakespeare demonise the choices of their female characters at times, they also refuse to represent womanliness as entirely positive, and Middleton and Dekker turn the negative model of femininity on its head, suggesting that acting like a girl can sometimes be more worthwhile and admirable than acting like a woman or a maiden. As these characters have shown, refusing to be a woman could sometimes mean performing girlhood, a concept that remains powerful and pervasive in our own culture. Like all discourses, the discourse of girlhood was fluid and contested, and it could be harnessed to subvert patriarchal social relations and to shore them up. The category of the 'girl' was available to imagine complex female identities, but it could also be rewritten as a less powerful, unthreatening category.

Moreover, many early modern women would not have wanted to embrace girlishness and some would have experienced being 'girled' as a negative experience. Sixteenth- and seventeenth-century women writers do not seem to have engaged as freely with the discourse of girlhood as men. I am reluctant to make generalisations about the differences between men's and women's representations of girls because the sample size of women's texts is so much smaller, and their texts are written in a rather wide range of genres. I also do not want to homogenise the variety of female voices out there in a way that suggests women's writing offers a monolithic vision of female childhood. However, until the Restoration, the term 'girl' is relatively rare in extant women's texts. Of the 172 texts included in the electronic database Renaissance Women Online, only six texts that were written or published prior to 1660 include the word 'girl' (in any of its spelling variations): Isabella Whitney's A Sweet Nosegay, Or Pleasant Posy: Containing a Hundred and Ten Philosophical Flowers (1573), Mary Tattlewell's The Women's Sharp Revenge (1640), Anne Bradstreet's The Tenth Muse Lately Sprung Up in America (1650), Mary Cary's The Little Horns Doom and Downfall (1651), Elizabeth Grey, Countess of Kent's recipe book A Choice Manual, or Rare and Select Secrets (1653), and Margaret Cavendish's play Nature's Pictures (1651). ${ }^{74}$ To this list I can add Jane Lumley's translation of Iphigenia at Aulis, which uses the term one time. $^{75}$ To put that in perspective, a complete search of the 172 texts in the database yields 145 hits in forty-three texts, the bulk of which were written for the Restoration stage by Margaret Cavendish or Mary Pix. Those statistics might look slightly different if Renaissance Women Online included women's manuscripts, but my own experience reading 
women's manuscripts suggests that it was not until women started writing for the professional stage that the discourse of girlhood became prominent in women's writing. Pre-Restoration women also strike me as less likely to associate girlhood with gender transgression and more likely to figure it as an age category. My sense is that this trend results from a combination of factors: the limited range of women's texts (the term 'girl' shows up most frequently, even in the Restoration period, in public drama), the writers' class statuses (young aristocratic girls are referred to as 'ladies' in letters and court masques), their focus on familial connections (they discuss 'daughters' rather than 'girls'), and the religious nature of many of the texts that women left behind. Except for those by Isabella Whitney, all the pre-1660 uses of 'girl' or 'girls' by women writers refer explicitly to female children rather than adult women engaging in girlish behaviour.

The presence of girls in Whitney's poem likewise reinforces the term's association with the lower classes. Scholarship on the woman who published the first original volume of poetry in English has been attuned to Whitney's status as a discharged servant as far back as Betty Travitsky's 1980 article that introduced many literary critics to Whitney's work. ${ }^{76}$ Although she is identified as a 'gentlewoman' on the title page, the content of the volume makes it clear that she is out of work and publishing her poems because she needs the money, being 'whole in body, and in mind, / but very weake in Purse' (lines 1-2). ${ }^{77}$ Patricia Phillipy has explored the way that Whitney's poetic description of service speaks to the experience of country women who migrated to London for work and who were compellable to serve yet faced uncertainties with regard to employment. ${ }^{78}$ In her most well-known poem the 'Wyll', Whitney brilliantly plays on will-writing conventions to lay claim to the material space of London and the wealth contained within, leaving the city itself as her executor.

In both Whitney's uses of the term 'girl', she displays an awareness of economic necessity. In the first instance, she associates girlhood with illicit sexuality, but it is not an illicit sexuality that results from conscious rebellion. Instead, Whitney evokes the world of the 'poor shifting sisters' whom the character Moll Frith describes as deserving sympathy rather than condemnation (3.1.100). In her description of the city, Whitney includes the young workers who cannot wed because their apprenticeships require them to be single and who, as a result, seek sexual satisfaction with prostitutes:

And handsome men, that must not wed

except they leaue their trade.

They oft shal seeke for proper Gyrles 
and some perhaps shall fynde:

(That neede compels, or lucre lurss

to satisfye their mind.)

(lines 115-20)

The ironised use of 'proper' in the above passage plays on the prostitutes' divergence from propriety even as they technically fulfil their 'proper' sexual roles in a heteronormative society. The poem's narrator recognises that some of those girls are drawn into the sex trade because of need, and that some of the girls simply give in to the lure of lucre. For some sex workers, girlishness is a choice, whereas for others, it is a necessity. Because of the demands of poverty, not all adult women have the ability to behave in the womanly fashion so lauded by conduct manuals. The narrator's awareness of social inequality leads her to hope for cross-class marriages that will work as a de facto means of redistributing wealth from rich widows to young men and from rich men to poor girls:

For Maydens poore, I Widdoers ritch, do leaue, that oft shall dote:

And by that meanes shal mary them, To set the Girles aflote.

And wealthy Widdowes wil I leaue, to help yong Gentylmen:

(lines 201-6)

Because of this attempt to redistribute wealth, Crystal Bartolovich has described Whitney as a proto-Leveller whose utopian vision imagines a world in which social wealth was shared according to need. ${ }^{79}$

The key for us as today's critics is that we do not assume that we know in advance what 'girlishness' means, not only because the meaning has changed since the early modern period but also because 'girlhood' has multiple and unstable meanings. Feminists seeking to refuse patriarchal positions as 'women' can tap into a discourse of girlhood, but that same discourse can be used by anti-feminists seeking to reclaim girlhood as a patriarchal category. And the very subversive potential of girlhood can become marketing tools as watered-down versions of 'Girl Power' that promise young women liberation through lipstick and sparkling T-shirts. In our multiplicities of girlhood, we are in many ways facing a similar but historically specific contestation over gender ideologies. Our language bears traces of the idea that acting like a girl is what makes you one. From signifying female friendship by calling each other 'girl' to indulging in a 'girls' night out', we continue to associate certain behaviours with girlishness. The principal difference lies in our direct 
association of those behaviours with the freedoms enjoyed within childhood communities. In the early modern period, performative girlhood was largely constructed as an adult privilege. Perhaps the best contemporary analogue of the unruly potential embedded in the category of the 'girl' would be feminist groups like the Guerrilla Girls or the Riot Grrrl musical movement of the 1990s. Although in some contexts being called a 'girl' can be infantilising, calling oneself a 'girl' can constitute a refusal of modern femininity and the gendered baggage that goes along with being categorised as a woman in our society. One might say, to reformulate Simone de Beauvoir's insightful comment, that if one is not born a woman, one is also not born a girl. My next chapter accordingly focuses on the 'girling' of female infants and the process through which being born with a female body would have set off the contingent processes through which female human beings were shaped into various female subject positions through lived encounters with their social world.

\section{Notes}

1. J. S., England's Merry Jester: Or, Court, City, and Country Jests, New, and Suitable to the Humours of the Times (London, 1693), sig. Cv-C2r.

2. Pamela Allen Brown, Better a Shrew than a Sheep: Women, Drama, and the Culture of Jest in Early Modern England (Ithaca: Cornell University Press, 2003).

3. Some of the most well-known defences of Eve include Jane Anger, Jane Anger Her Protection for Women (London, 1589), Constantia Munda, The Worming of a Mad Dog (London, 1617), Esther Sowernam, Esther Hath Hang'd Haman (London, 1617), and Rachel Speght, A Movzell for Melastomvs (London, 1617). For excerpts of texts from the debates over the woman question in England, see Katherine Usher Henderson and Barbara F. McManus (eds), Half Humankind: Contexts and Texts of the Controversy about Women in England, 1540-1640 (Urbana: University of Illinois Press, 1985), and Betty Travitsky (ed.), The Paradise of Women: Writings by Englishwomen of the Renaissance (Westport, CT: Greenwood Press, 1981). For a critical discussion of the woman question, see Linda Woodbridge, Women and the English Renaissance: Literature and the Nature of Womankind, 1540 to 1620 (Urbana: University of Illinois Press, 1984).

4. Monique Wittig, 'One Is Not Born a Woman', in Henry Abelove, Michèle Aina Barale and David M. Halperin (eds), The Lesbian and Gay Studies Reader (New York: Routledge, 1993), p. 103, emphasis in original.

5. Sara Mendelson and Patricia Crawford, Women in Early Modern England, 1550-1720 (Oxford: Oxford University Press, 1998), pp. 75-6. They are quoting Lyndal Roper, Oedipus and the Devil: Witchcraft, Sexuality, and Religion in Early Modern Europe (New York: Routledge, 1994), pp. 16-27. 
6. Judith Butler, Gender Trouble: Feminism and the Subversion of Identity (New York: Routledge, 1990); see especially p. 5 where she remarks, 'Feminist critique ought also to understand how the category of "women," the subject of feminism, is produced and restrained by the very structures of power through which emancipation is sought.'

7. Judith Butler, Undoing Gender (New York: Routledge, 2004), p. 10.

8. Anthony Fletcher, Gender, Sex, and Subordination, 1500-1800 (New Haven: Yale University Press, 1995).

9. Karen Newman, Fashioning Femininity and English Renaissance Drama (Chicago: University of Chicago Press, 1991), p. 25. See especially her chapter on marriage, 'The Crown Conjugal: Marriage in Early Modern England', pp. 15-31.

10. See, for example, Thomas Becon, who repeatedly uses this phrase in his 1564 A New Catechisme sette forth in Dialoge wise in familiare talke between the father and son, in The Catechism of Thomas Becon, ed. John Ayre, Parker Society Reprint (Cambridge: Cambridge University Press, 1968). See also Robert Cleaver's command that 'fathers and mothers do instruct and bring up their children euen from the cradle, in the fear and nurture of the Lord' in A Godly Form of Household Government (London, 1598), p. 346.

11. Lady Grace Mildmay, 'Autobiography', in Linda Pollock (ed.), With Faith and Physic: The Life of a Tudor Gentlewoman: Lady Grace Mildmay, 1552-1620 (London: Collins \& Brown, 1993), p. 25.

12. Ilana Krausman Ben-Amos, Adolescence and Youth in Early Modern England (New Haven: Yale University Press, 1994), pp. 12-13.

13. Hugh Cunningham, Children and Childhood in Western Society since 1500 (New York: Longman, 1995), pp. 57-61.

14. Elizabeth Isham, Book of Remembrance, MS RTC01 no. 62, Robert H. Taylor Collection, Manuscripts Division, Department of Rare Books and Special Collections, Harvey S. Firestone Library, Princeton University, fol. 2v. I am using Alice Eardley's transcription on the website 'Constructing Elizabeth Isham', <http://www2.warwick.ac.uk/fac/arts/ren/projects/ish am> (accessed 27 June 2012).

15. John Duncon, The Returnes of Spiritual Comfort and Grief in a Devout Soul (London, 1649), sig. H2v-H3r.

16. Mildmay, 'Autobiography', p. 28.

17. Rebecca Bushnell, A Culture of Teaching: Early Modern Humanism in Theory and Practice (Ithaca: Cornell University Press, 1996).

18. Juan Luis Vives, The Instruction of a Christen Woman, ed. Virginia Walcott Beauchamp, trans. Richard Hyrde (Urbana: University of Illinois Press, [1529] 2002), p. 13.

19. Bushnell, A Culture of Teaching, p. 111.

20. Vives, Instruction of a Christen Woman, p. 14.

21. Ibid. p. 8.

22. Vives, Instruction of a Christen Woman, xli-xlii, n. 6.

23. See Juan Luis Vives, De institutione foeminae Christianae, ed. Charles Fantazzi and Constantinus Matheeussen (Leiden: Brill, [1524] 1996), p. 26, and Vives, Instruction of a Christen Woman, p. 19.

24. As I discuss later, Shakespeare's Joan la Pucelle inflects her transgressions 
of gender not only through wearing masculine attire, but also by claiming aristocratic class privilege as a peasant 'girl' seeking to be a 'holy maid'. As a lowly shepherdess, Joan would otherwise have been excluded from the educational programme imagined by Vives.

25. Bushnell, A Culture of Teaching, p. 111.

26. Richard Mulcaster, Positions Concerning the Training Up of Children, ed. William Barker (Toronto: University of Toronto Press, [1581] 1994), p. 177.

27. Lucy Hutchinson's precocity provides an historical case study of the rapidity with which girls could learn. Hutchinson reports, 'I was so apt that I outstript my brothers who were at school, although my father's chaplain that was my tutor was a pitifull dull fellow. My brothers, who had a great deal of wit, had some emulation at the progress I made in my learning, which very well pleased my father, though my mother would have been contented I had not so wholly addicted myself to that as to neglect my other qualities.' Quoted in Nancy McMullen, 'Education of English Gentlewomen', History of Education 6 (1977), p. 99.

28. Roger Ascham, The Scholemaster (London, 1570), p. 12.

29. Ibid. p. 12.

30. Becon, A New Catechisme, pp. 376-7.

31. Louis Althusser, 'Ideology and Ideological State Apparatuses', trans. Ben Brewster, in Lenin and Philosophy and Other Essays (New York: Monthly Review, 1972), pp. 127-93.

32. Becon, A New Catechisme, p. 375.

33. Newman, Fashioning Femininity, p. 123.

34. Hic Mulier, or, the Man-Woman (London, 1620) and Haec Vir, or, The Womanish Man (London, 1620).

35. George Gascoigne, The Adventures of Master F. J., in A Hundreth Sundrie Flowres (London, 1573), pp. 164-5. All page-number references to The Adventures of Master F. J. are to this edition.

36. Roy Eriksen has suggested that this move represents a deliberate break with the preceding alliterative pairings. For Eriksen, this is an example of the novella's Italian mannerist style, which he characterises as marked by a transgressive aesthetics that defies our expectations of form. See his 'The Mimesis of Change: Gascoigne's Adventures of Master F. J. (1573)', in Eriksen (ed.), Contexts of Pre-Novel Narrative: The European Tradition (Berlin: Mouton de Gruyter, 1994), p. 208. If this is a conscious decision on the part of Gascoigne (though not the narrator), it furthers my argument that the text both raises expectations that Frances will triumph and then undermines those expectations.

37. Steve Mentz, 'Escaping Italy: From Novella to Romance in Gascoigne and Lyly', Studies in Philology 2 (2004), p. 163.

38. Susan Staub, 'The Lady Frances Did Watch: Gascoigne's Voyeuristic Narrative', in Constance Relihan (ed.), Framing Elizabethan Fictions: Contemporary Approaches to Early Modern Narrative (Kent: Kent State University Press, 1996), pp. 41-54.

39. Gascoigne, The Posies (London, 1575), sig. R1r.

40. Gascoigne justifies this move as follows: 'And because I do suppose that Leonora is the same name whiche wee call Elinor in English, and that 
Francischina also doth import none other than Fraunces, I will so entitle them as to our on countriemen may be moste perspicuous.' See The Posies, sig. R1v.

41. G. W. Pigman III, 'Editing Revised Texts: Gascoigne's A Hudredth Sundrie Flowres and The Posies', in W. Speed Hill (ed.), New Ways of Looking at Old Texts, II: Papers of the Renaissance English Text Society, 1992-1996 (Tempe: Medieval and Renaissance Texts and Studies, 1998), p. 6.

42. This is true of both Pigman's edition, which provides textual variations between Master F. J. and The Pleasant Fable throughout the footnotes, and Paul Salzman's edition in An Anthology of Elizabethan Prose Fiction, which includes an addendum with the alternate ending.

43. 'His claim to have cleaned up the book', writes Felicity A. Hughes, 'is consistently undermined by ironies, jokes, and patent bare-faced lies.' See Hughes, 'Gascoigne's Poses', Studies in English Literature, 1500-1900 37 (1997), p. 2. Hughes points to the obviously fictitious claim that The Pleasant Fable is a translation from Bartello and to the multiple insinuations that Bartello is Gascoigne in other places in The Posies. She argues that instead of reading The Posies as a genuine attempt to appease the censors and reform his writing, we should see it as an ironic pose meant to use humour to defuse possible objections. G. W. Pigman III agrees. 'Gascoigne', he writes, 'is mocking the reverend divines with ungelded, but plausibly deniable, puns.' Their arguments are supported by the fact that we have records of Her Majesty's High Commission seizing copies of the 1575 volume. See Pigman, 'Editing Revised Texts', p. 7. I agree with both Hughes and Pigman, but my argument does not hinge on Gascoigne's intentions. Whether or not his pose is genuine and whether he means for the tale to work as a moral, I would argue that it fails to do so.

44. Gascoigne, The Posies, sig. S2v.

45. Ibid. sig. S2v.

46. Gascoigne, The Adventures of Master F. J., p. 215.

47. Ibid. p. 61.

48. Judith Halberstam, Female Masculinity (Durham, NC: Duke University Press, 1998).

49. Jean E. Howard and Phyllis Rackin, Engendering a Nation: A Feminist Reading of Shakespeare's English Histories (New York: Routledge, 1997), p. 44.

50. Ibid. p. 44.

51. Theodora Jankowski, Pure Resistance: Queer Virginity in Early Modern English Drama (Philadelphia: University of Pennsylvania Press, 2000), p. 12.

52. Ibid. p. 12.

53. As several critics have noted, the very act of cross-dressing would have linked Joan with witchcraft, and Edward Hall describes her wearing of armour as a sign of her status as a witch. See Gabrielle Bernard Jackson, 'Topical Ideology: Witches, Amazons, and Shakespeare's Joan of Arc', English Literary Renaissance (1988), pp. 40-65, and Howard and Rackin, Engendering a Nation, p. 45.

54. See Tamburlaine's declaration, 'I that am termed the scourge and wrath of God, / The only fear and terror of the world, / Will first subdue the Turk and then enlarge / Those Christian captives which you keep as slaves' 
(3.3.44-7). Christopher Marlowe, Tamburlaine the Great, Part One, in The Complete Plays, ed. Frank Romany and Robert Lindsey (London: Penguin, 2003).

55. Jankowski, Pure Resistance, p. 1.

56. Butler, Undoing Gender, p. 3.

57. Articles focusing on Mary Frith's transvestism include Patrick Cheney, 'Moll Cutpurse as Hermaphrodite in Dekker and Middleton's The Roaring Girl', Renaissance and Reformation 7 (1983), pp. 120-34; Marjorie Garber, 'The Logic of the Transvestite: The Roaring Girl', in David Scott Kastan and Peter Stallybrass (eds), Staging the Renaissance: Reinterpretations of Elizabethan and Jacobean Drama (New York: Routledge, 1991), pp. 221-34; and Mary Beth Rose, 'Women in Men's Clothing: Apparel and Social Stability in The Roaring Girl', English Literary Renaissance 14 (1984), pp. 367-91. For an analysis of the importance of the male actor playing Mary Frith, see Stephen Orgel, 'The Subtexts of The Roaring Girl', in Susan Zimmerman (ed.), Erotic Politics: Desire on the Renaissance Stage (New York: Routledge, 1992), pp. 12-26.

58. For an account of Moll as a single woman (though not specifically her position as a girl), see Adrienne L. Eastwood, 'Controversy and the Single Woman in The Maid's Tragedy and The Roaring Girl', The Rocky Mountain Review of Language and Literature 58 (2004), pp. 7-27.

59. Early feminist explorations of Moll's subversive potential include Jean E. Howard, 'Sex and Social Conflict: The Erotics of The Roaring Girl', in Erotic Politics, pp. 170-90; Susan E. Krantz, 'The Sexual Identities of Moll Cutpurse in Dekker and Middleton's The Roaring Girl and in London', Renaissance and Reformation 19 (1995), pp. 5-20; and Viviana Comensoli, 'Play-making, Domestic Conduct, and the Multiple Plot in The Roaring Girl', Studies in English Literature 37 (1997), pp. 249-66. For work on Moll's association with the criminal classes, see Jodi Mikalachki, 'Gender, Cant, and Cross-talking in The Roaring Girl', Renaissance Drama 25 (1994), pp. 119-43; Miles Taylor, “"Teach Me This Pedlar's French”: The Allure of Cant in The Roaring Girl and Dekker's Rogue Pamphlets', Renaissance and Reformation 29 (2005), pp. 107-24; Clare McManus, 'The Roaring Girl and the London Underworld', in Garret Sullivan, Patrick Cheney and Andrew Hadfield (eds), Early Modern English Drama: A Critical Companion (Oxford: Oxford University Press, 2006), pp. 213-24. For work that looks at Moll's geographic and social relationship to her London world, see Nathasha Korda, 'The Case of Moll Frith: Women's Work and the "AllMale Stage"', Early Modern Culture 4 (2004), <http://emc.eserver.org/1-4/ korda.html> (accessed 21 June 2012); and Kelly J. Stage, 'The Roaring Girl's London Spaces', Studies in English Literature 49 (2009), pp. 417-36.

60. See Stephen Orgel, Impersonations: The Performance of Gender in Shakespeare's England (Cambridge: Cambridge University Press, 1996), pp. 149-50.

61. All Roaring Girl quotations are from the Revels edition: Thomas Middleton and Thomas Dekker, The Roaring Girl, ed. Paul Mulholland (Manchester: Manchester University Press, [1611] 1987).

62. Jean E. Howard, The Stage and Social Struggle in Early Modern England (London: Routledge, 1993), p. 127. 
63. Jane Baston, 'Rehabilitating Moll's Subversion in The Roaring Girl', Studies in English Literature 37 (1997), pp. 317-35, and Deborah Jacobs, 'Critical Imperialism and Renaissance Drama: The Case of The Roaring Girl', in Dale M. Bauer and Susan Jaret McKinstry (eds), Feminism, Bakbtin, and the Dialogic (Albany: SUNY Press, 1991), pp. 73-84.

64. Baston, 'Rehabilitating Moll's Subversion', p. 332, p. 326.

65. Alicia Tomlinson, 'Moll's Law: The Roaring Girl, Mary Frith, and Corrupt Justice from the Streets to the Star Chamber', Ben Jonson Journal 15 (2008), pp. 206-7.

66. Kate Bornstein, Gender Outlaw: On Men, Women, and the Rest of Us (New York: Routledge, 1994).

67. Butler, Undoing Gender, p. 8.

68. 'Consistory Court of London, Correction Book, fols. 19-20', in S. P. Cerasano and Marion Wynn-Davies (eds), Renaissance Drama by Women: Texts and Documents (London: Routledge, 1996), p. 172.

69. For an account of the debate over the real woman's appearance on the Fortune stage, see Mark Hutchings, 'Mary Frith at the Fortune', Early Theatre 10 (2007), pp. 89-108.

70. Quoted in Paul Mulholland, 'The Date of The Roaring Girl', Review of English Studies 28 (1977), p. 24.

71. Ann Rosalind Jones, The Currency of Eros: Women's Love Lyric in Europe, 1540-1620 (Bloomington: Indiana University Press, 1990), p. 3.

72. Ibid. pp. 5-6.

73. Ibid. p. 4.

74. Renaissance Women Online, Women Writers Project, Brown University, <http://www.wwp.brown.edu> (accessed 30 October 2011). I have excluded the play Swetnam, The Woman-Hater, Arraigned by Women (1620), because as a play written for the public stage, it may be of relevance to students of women's literature but was not written by a woman.

75. British Library Royal MS 15.A.9.

76. Betty Travitsky, 'The "Wyll and Testament" of Isabella Whitney', English Literary Renaissance 10 (1980), p. 78.

77. Isabella Whitney, 'The Maner of her Wyll', in A Sweet Nosegay, Or Pleasant Posye: Containing a Hundred and Ten Philosophical Flowers (London, 1573).

78. Patricia Phillipy, 'The Maid's Lawful Liberty: Service, the Household, and "Mother B" in Isabella Whitney's A Sweet Nosegay', Modern Philology (1998), pp. 439-62. On the poem's construction of service and class, see also Ann Rosalind Jones, 'Maidservants of London: Sisterhoods of Kinship and Labor', in Karen Robertson and Susan Frye (eds), Maids and Mistresses, Cousins and Queens: Women's Alliances in Early Modern England (Oxford: Oxford University Press, 1999), pp. 21-32, and Jane Donawerth, 'Women's Poetry and the Tudor-Stuart System of Gift Exchange', in Donawerth, Linda Dove and Karen Nelson (eds), Women, Writing, and the Reproduction of Culture in Tudor and Stuart Britain (Syracuse: Syracuse University Press, 2000), pp. 3-18.

79. Crystal Bartolovich, "Optimism of the Will": Isabella Whitney and Utopia', Journal of Medieval and Early Modern Studies 39 (2009), pp. 407-32. 


\section{Chapter 3}

\section{Female Infants and the Engendering of Humanity}

On the early modern public stage two types of characters were literally inhuman: infants and live animals. What they had in common was that no actors performed their parts. Infants were represented by bundles of blankets or dolls rather than live children, and in the absence of a body beneath the bearing cloth, the only markers of the fictional infant's human status were the actions and words of the players. Without them, the infants would have remained in a thing-like state, suspended somewhere between prop and character.

Infants on stage had to be personified and imagined as human beings because the absence of infants, like the absence of women, was one of the material conditions of Shakespeare's stage. Infants then as now could not be relied upon to remain silent as needed, and they could easily have disrupted a performance, as we know from several Victorian-era productions that were spoiled by the untimely crying of their smallest cast members. ${ }^{1}$ Given the non-realist mode of the early modern theatre, ${ }^{2}$ audiences would have been less likely than Victorian viewers to regard the substitution of dolls for 'real live' infants as 'absurdities', making the necessity of taking the risk less worthwhile. ${ }^{3}$ Moreover, live babies would have required a caretaker, since the Victorian practice of using one of the actress's children would not have been an option with an allmale cast. ${ }^{4}$ They could theoretically have used one of the shareholder's children, but they apparently did not. I have found no records of such payments for the public stage, ${ }^{5}$ and it is hard to imagine a company being given the use of a child without having to compensate its guardian. Instead, evidence suggests that early modern professional acting troupes followed medieval religious drama in using various forms of 'counterfeit children' ${ }^{6}$

Stage infants thus crystallised in material form the prevailing early modern perception of children as at once human and not-quitehuman. To borrow Erica Fudge's formulation, children were frequently 
described as 'creatures' in early modern scientific literature and educational manuals because rationality marked the theoretical divide between the human and the animal. ${ }^{7}$ Women and children, as Fudge's work has shown, occupied a conceptual space in between these two categories and were only partially admitted into the category of the human. To be fully human required the dual possession of an ingrained capacity for reason and an education to cultivate that reason. As such, the status of the fully human was restricted to adults, and, importantly, to adult men. Women and children, on the other hand, were seen as 'more fragile, and as such somehow closer to - although always different from - animals' ${ }^{8}$ The stage infant's inanimate nature would have echoed the ideology that perceived children, and especially female children, as only problematically human. In life and on stage, infant girls would have occupied the doubly liminal position of being both young and female in a system that privileged maturity and maleness.

How, then, were female infants on stage personified and imagined as human beings? Using three of Shakespeare's late plays and two of Thomas Middleton's city comedies that feature female infants, I argue that one way of encouraging the audience's sympathetic engagement with these mute dolls was to imagine them as male or female. By identifying the fictional infant thus, an actor automatically imbued the child-prop with a certain level of humanity. To create the dramatic illusion that these inanimate bundles were human characters, early modern playwrights had their characters describe these neuter objects as gendered subjects. Shakespeare in particular took advantage of this performative act in his late romances Pericles, The Winter's Tale and Henry VIII as part of a larger project of reimagining monarchical succession via daughters rather than sons. Using the staging of female infancy as a dramatic mechanism for replacing the story of boyhood with the story of girlhood, Shakespeare rewrites the dynastic family narrative as an affective family romance. Female infants likewise get marked as human via gender in Middleton's A Fair Quarrel and A Chaste Maid in Cheapside, but whereas Shakespeare focused on princesses, Middleton depicted middle-class girls as the affective locus of kinship networks. Middleton deprioritises legitimacy in favour of social recognition and communal support as the factors that determine the infant's humanity, but for infants of both classes in both dramatic genres, to be spoken of as human, they first had to be spoken of as male or female. 
Although critics have recognised that daughters played prominent roles in Shakespeare's late plays, the particularity of the young women's initial identities as infants has not been emphasised. ${ }^{9}$ Shakespeare's first experiment with an infant character - and one of the earliest appearances of an infant in the professional theatre - was Aaron's son in Titus Andronicus (1592). It was not until a decade later, however, that Shakespeare, Thomas Heywood, Thomas Middleton and others made the staging of infancy into a theatrical convention, and then it was female babes-in-arms that served as the focal point for Shakespeare's explorations of childhood and gender. While Aaron's son raises issues about miscegenation and illegitimacy, Shakespeare's female infants query the relationship between the body, gender and human identity.

Among the playwrights who participated in the minor seventeenthcentury vogue for using infants as stage props, Shakespeare stands apart due to his marked interest in girls. Infants were carried on stage in nearly forty extant plays from the pre-Civil War period, including works classifiable as comedies, tragedies, histories and romances, from Robert Wilson's morality play The Cobbler's Prophecy (published 1594) to John Fletcher's comedy The Chances (c. 1617) to Philip Massinger's tragedy The Unnatural Combat (c. 1624). (See Appendix at page 135 for complete chart.) Of the thirty-eight plays that I have identified, twenty-five included boys, ten included girls, and five included children of indeterminate gender. ${ }^{10}$ The representation of female infants spikes slightly in the Jacobean period, predominantly because of Shakespeare.

Why female infants, especially royal female infants, should have taken centre stage is a difficult question to answer. Critics have traditionally looked to Shakespeare's life and his connections to Jacobean politics for an explanation. The events in Shakespeare's family life between the years 1607 and 1613 resonate strikingly with his late plays. ${ }^{11}$ The 1607 death of Shakespeare's two-year-old niece, the daughter of his sister Joan Hart, offers a tantalising suggestion that dramatising the recovery of Marina imagines the possibility of undoing his sister's loss. Perhaps even more tempting is reading Pericles in light of the knowledge that in February 1608 Shakespeare's daughter Susanna Hall gave birth to a child named Elizabeth, making Shakespeare a grandfather for the first time. Reading Shakespeare's interest in female infants as sparked by these children is complicated by the fact that not all the births in the Shakespeare family in 1608 were girls. His nephew Michael Hart was also born that year. Although it would be hard to deny that these events had an impact on 
his work, especially with regard to the material he chose to refashion, it would be reductive to attribute the complex negotiations of childhood and gender in these plays entirely to personal experience. I do not mean to suggest all biographical critics have done so, ${ }^{12}$ but to read the plays first and foremost as reflections of Shakespeare's life seems to me ultimately unsatisfying. Without a corresponding interpretation of the play itself, it is unclear to me what we get out of aligning Marina with Shakespeare's granddaughter, or, as has sometimes been suggested, seeing Mamillius's death as figuring the irrecoverable loss of his son Hamnet fourteen years before he wrote The Winter's Tale. ${ }^{13}$ Even if these experiences filtered into the plays, the questions that emerged from Shakespeare's own life would have been refracted through the lens of the world in which he lived.

Rather than seeing Shakespeare's infants as referring to emotional attachments in his own family, this chapter seeks to position them within the larger framework of early modern constructions of girlhood. In order to do so, I will be drawing on existing political readings of the romances that offer promising, though partial, explanations of Shakespeare's interest in royal girls. ${ }^{14}$ At the beginning of the seventeenth century, the English court had a royal family at its centre for the first time since Henry VIII, an historical development that accounts to some extent for the focus on affective family relations and succession in Shakespeare's Jacobean plays. ${ }^{15}$ Like Joan Hart, Anne of Denmark lost two daughters around the time Shakespeare would have been writing Pericles, newborn Sophia in June 1606 and two-year-old Mary in summer 1607. Just as importantly, 1608 was the year that Princess Elizabeth, the future Winter Queen, took her place in the court in London. It was surely no coincidence that Shakespeare's Henry VIII celebrated the infant Queen Elizabeth in the same year as Elizabeth's marriage to Frederick of Bohemia. Protestant propaganda had come to figure the princess as a second Elizabeth, especially after Prince Henry's death in 1612 made her their best hope for a royal champion against Catholicism. ${ }^{16}$ But even if we take the Protestant championing of Princess Elizabeth into account, it still does not explain why Shakespeare would have chosen to focus on her rather than her brother before his death. David Bergeron has offered a beautiful reading of the way that the romances confront the problems inherent in the Stuart family's conflation of domestic and political concerns, but the politics of the royal family cannot fully explain why Shakespeare would turn to girls rather than boys as the royal heirs who can 'redeem their kingdoms by providing much-desired stability'. ${ }^{17}$ As the aforementioned tragicomedies from the turn of the century demonstrate, Shakespeare could easily have found examples of lost princes 
and male heirs in the literary tradition. He chose instead to look to John Gower's Confessio Amantis, The Patterne of Painful Adventures, Robert Greene's Pandosto, and historical accounts of the life of Henry VIII, all texts that feature lost princesses.

By portraying female infants, Shakespeare takes advantage of an unusual situation on the early modern stage - the representation of female characters without male actors. Early modern drama gestured frequently to the boy actor's covert male presence behind the woman he personated, as Peter Stallybrass, Stephen Orgel and Phyllis Rackin among others have ably explored. ${ }^{18}$ For Juliet Dusinberre, the absence of female bodies from the stage actually made it less sexist than it would otherwise have been, since female impersonation by definition deessentialises the connection between body and gender identity. ${ }^{19}$ Others, most notably Stephen Greenblatt, have cast doubt on whether the early modern stage represents female identity at all. ${ }^{20}$

Since the publication of Thomas Laqueur's influential Making Sex in 1990, it has become commonplace to note that both biologically and socially adult men were imagined to pass through a feminised state before arriving at adulthood, especially after Stephen Greenblatt brought Laqueur's work on the one-sex model to bear on literary studies. ${ }^{21}$ Under the Galenic model, male and female sexual organs were seen as homologous. The difference was believed to be the result of differences in body heat, such that foetuses that lacked the heat to thrust out sexual organs would not fully develop and would become female. As a result, the state of being female appears as a stage on the way to maleness. Drawing on the one-sex model, Greenblatt's influential essay 'Fiction and Friction' reads Shakespeare's Twelfth Night as an extension of the Galenic one-sex model. He argues that since Renaissance notions of the body held all human beings to contain both male and female elements, the figure of the cross-dressed female page brought male and female elements into erotic friction. The underlying 'reality' of the 'identifiably male' body beneath the actors' clothes secures male identity while the fiction of sexual difference keeps desire in the realm of heterosexuality. ${ }^{22}$

According to Greenblatt, 'Nature is an unbalancing act', and heterosexual couplings are 'natural' in the Renaissance. ${ }^{23}$ Yet despite Greenblatt's insistence on the need for masculinity and femininity to create erotic friction, he reinforces the presence of a universal male subjectivity. Rather than seeing Viola's use of disguise as part of constructing a female identity, Greenblatt sees Shakespeare's women as reflections of male identity: 
Though Shakespeare characteristically represents his women characters-Rosalind, Portia, Viola-as realizing their identities through crossdressing, this whole conception of individuation seems to me bound up with Renaissance conceptions of male identity ... If a crucial step in male individuation is separation from the female, this separation is enacted inversely in the rites of cross-dressing; characters like Rosalind and Viola pass through the state of being men in order to become women. Shakespearean women are in this sense the representation of Shakespearean men, the projected mirror images of masculine self differentiation. ${ }^{24}$

Echoing Freudian accounts of male sexual development, Greenblatt writes out women from Shakespeare's plays except in so far as they reflect the development of men. The problem, of course, is that Shakespeare's women do not pass through the state of being men; they pass, as Mark Johnston has pointed out, through the state of being boys - a crucial distinction. ${ }^{25}$ Moreover, Greenblatt's analysis inscribes what Luce Irigaray calls 'sexual (in)difference', whereby women only exist as mirrors for male identity. ${ }^{26}$

Janet Adelman has criticised the one-sex model, pointing out that many of Laqueur's examples derive from Continental sources, and that a competing two-sex model existed in English medical discourse. She also questions whether medical texts can serve as an accurate gauge for the general public's understanding of their bodies, and points out that the one-sex model makes 'certain traditional feminist concerns irrelevant' by evacuating the threat posed by female difference. ${ }^{27}$ Dympna Callahan, on the other hand, takes the absence of women from Shakespeare's stage as the departure point for a feminist interrogation of the difference between presence and representation. ${ }^{28}$ Like Callahan, I focus on an absence to interrogate the political uses to which the representations of female infants as gendered subjects could be put. Where Callahan's work aims to pay attention to the way roles in early modern drama were written for white men, my aim is to pay attention to the way the roles of female infants weren't written for human beings at all.

To identify an infant as female is to explore the process through which biological sex becomes socially legible, staging the speech act that imagines infants as gendered human beings. 'Gender', in the words of Judith Butler, 'figures as a precondition for the production and maintenance of legible humanity. ${ }^{29}$ What I find striking about Butler's recent work on the category of the human is the extent to which the definition of what constitutes a distinctively human life depends so heavily upon language and speech. When Butler raises the question of what and who counts as human, she cannot help but raise the issue of the speaking 'I'. 'One speaks,' she writes, 'and one speaks for another, to another.' ${ }^{30}$ Through 
the technologies of the early modern theatre, Shakespeare tackled the question of how to account for one who does not speak but has to be spoken of and for, using the stage as 'a site of power in which the human [was] produced and reproduced - not just the humanness of the child but also the humanness of those who [bore] and those who raise[d] children, parents and nonparents alike'. ${ }^{31}$

A significant difference exists between plays that use infants predominantly for their symbolic import and Shakespeare's late plays, which sought to humanise the infants Marina, Perdita and Elizabeth I. We should not let the familiarity of Shakespeare's plays naturalise the emotional role that his female infants occupy. Although Shakespeare draws from a long dramatic tradition of staging infancy, his gendering and humanising of infants have a distinctive force to them. The use of counterfeit infants in drama had roots in medieval religious plays, particularly those that present Herod's slaughter of the innocents, such as the Towneley and Coventry cycles. In these plays, women have their babes-in-arms taken from them and murdered, and the early modern plays that continue the tradition of staging infanticide evoke pathos through the display of the children's vulnerability. Thomas Hughes's Inns of Court play The Misfortunes of Arthur (1588) features a dumb show in which a soldier tears a 'counterfeit child' from the arms of a courtly lady and dashes it against a wall, an act that the script allegorises as 'the fruit of Warre, which spareth neither man woman nor chil[d]' (4.1).32 A similar moment in Alphonsus, Emperor of Germany (c. 1594; published 1654) sees the Duke of Saxon unknowingly dashing his own son's brains out because he misguidedly believes the boy to be the son of his rival. ${ }^{33}$ The play uses the scene to illustrate the destructive effects of tyrannous behaviour. The Tragedie of Nero (1624) returns to the use of the dead infant as symbol but in a less obviously allegorical mode than The Misfortunes of Arthur. The lamentations of a woman who enters carrying her 'burnt child' serve, along with a subsequent appearance of a man who has lost his wife, to express the general human cost of Rome's wrack and ruin. ${ }^{34}$ The difference between these tragic devices and the deployment of infancy in Shakespeare's late plays lies in the latter's use of infants as characters-to-be rather than emblems. If infants in tragedy exist to be killed, infants in Shakespeare exist to grow up.

That is not to say that infants do not occasionally reappear as children or adults in plays not written by Shakespeare, but they tend to remain ancillary to their parents' narratives. The infant son and daughter in both early modern versions of Patient Grissill reappear on stage as part of a family reconciliation that faintly echoes the end of The Winter's Tale, but the children themselves play little role in the story. ${ }^{35}$ In general, 
infants in non-Shakespearean comedies function predominantly as material evidence of sexual activity. Martia's baby in The Blind Beggar of Alexandria (1598), for example, acts as a visual sign of her affair with Cleanthes. ${ }^{36}$ The same is true of Thomas Heywood's A Maidenhead Well Lost (1634), where the son of Julia and the Prince of Parma proves their marriage and prevents her from being married to the Prince of Florence. ${ }^{37}$ Having initially rejected the pregnant Julia due to the Iagolike machinations of the Duke's secretary Stroza, Parma realises that he has been misled about Juliet's faithfulness when he witnesses the resemblance of the infant to himself. He rescues the child from death by exposure, to which Julia's father the Duke of Milan has committed it, and produces the infant on a covered dish at the banquet attending Julia's nuptials with Florence. The child-prop offers dramatic proof that Julia is no longer a virgin and becomes the grounds upon which Parma can reclaim her as his wife.

More akin to Shakespeare's late plays were The Thracian Wonder (c. 1600; published 1661), Tom a Lincoln (c. 1600) and The Weakest Goeth to the Wall (1600). In The Thracian Wonder, the princess Ariadne flees with her infant son Eusanius, having incurred her father's anger by secretly marrying Radagon, a prince of Sicily. After being separated from her child, she takes refuge amongst a group of shepherds, where Eusanius reappears at the age of twenty. ${ }^{38}$ Likewise, Tom a Lincoln (c. 1600), based on the popular romance of the same name, features two boys, the illegitimate offspring of King Arthur and the Mayor of London's daughter. The play stages the abduction of the infant children from their mother, and then follows their adventures before reuniting them. ${ }^{39}$ Although we do not know who performed The Thracian Wonder or Tom a Lincoln, the title page of The Weakest Goeth to the Wall claims it was performed by the Lord Chamberlain's men, so it is likely that Shakespeare would have come into contact with this play. ${ }^{40}$ Telling the story of a war between Lodwicke, Duke of Bullen, and Mercury, Duke of Anjou, the play opens with a dumb show that mimics the discovery of Moses in the bulrushes. Fleeing the troops of Anjou, the Duchess of Burgundy leaves Lodwicke's infant son Fredericke on the river bank before she herself leaps into the river and drowns. Discovered by his uncle Philip, the Duke of Brabant, Fredericke eventually reunites with his father and resumes his proper social position. Drawing on the same romance tropes as Shakespeare's Pericles and The Winter's Tale, The Weakest Goeth to the Wall has Lodwicke, like Leontes and Pericles, falsely believe his wife and child have died, and, like Shakespeare's romances, the anonymous play's resolution rests upon the reunification of the family. The similarities end there, however, as Shakespeare turns the political and gender 
roles upside down. The Weakest tells a largely political and dynastic tale, focusing on the conflict between the dukes, the ensuing battles and Lodwicke's eventual triumph over Mercury. In Pericles and The Winter's Tale, on the other hand, Shakespeare raises familial and domestic conflicts to the realm of the political, and he reverses the gender roles. Where Lodwicke recovers his son, Pericles and Leontes recover their daughters; where Fredericke's marriage gives Lodwicke a daughter-in-law, Perdita's and Marina's marriages provide their fathers with sons-in-law. Instead of political triumph in war and politics, victory in Shakespeare is the reunion and regeneration of the royal family.

To understand the stakes of identifying infants as both royal and female in Shakespeare's plays, we need to understand the complexities of infancy as a life stage in early modern England. Presenting the biological sex of infants on stage would have been a complicated performative act because sexual differences between them were in many ways not yet socially legible. We can see this most clearly if we return to the woodcut from John Amos Comenius's Orbis Sensualium Pictus that I discussed in Chapter 1 (see Figure 1). ${ }^{41}$ By representing women's lives as also divisible into stages, Comenius divides children into 'boys and girls' and 'damsels and youths', just as adults were divided into 'men and women'. Like the 'maid, wife, widow' schema, this particular progression makes life into a progress through mutually exclusive stages, with age rather than marriage enabling the transition from one to the next. Interestingly, infancy is the only stage for which the woodcut does not include separate male and female representatives. Even as seventeenth-century taxonomies were dividing childhood into the distinguishable categories of boyhood and girlhood, infancy remained unique in that future sexual differences had not become socially (and in this case visually) legible because the clothing of infants was gender neutral. If sexual distinctions between children in early modern England were less marked than in adulthood, infancy was a time when sexual differences had not yet manifested as easily distinguishable gender differences. ${ }^{42}$ Parents were often interested in the biological sex of their children, but the social and bodily processes through which male and female children were differentiated had not yet taken place. The difficulty of telling unbreeched boys from girls in early modern paintings is well known; ${ }^{43}$ imagine how much more difficult it would have been to tell a male infant from a female one, given that the swaddling bands and blankets of infancy had no gender markers. 
Moreover, infants, like preadolescent children, have not yet manifested secondary sex characteristics, making it harder to determine their gender. In the process of criticising midwives for claiming to be able to divine the sex of a child in the womb, Jacques Guillemeau reveals how indistinct sexual differences between infants can be. In his medical tract, Child-birth, or The Happy Deliverie of Women, translated into English in 1612, Guillemeau points out that knowing whether a woman had conceived a child could be difficult early in her pregnancy and that discovering the sex of the child before birth was even more challenging. Though he admits that 'there are some that boast they can certainely do it', Guillemeau suggests that they do so 'rather by chance than through either arte or skill'. ${ }^{44}$ To prove that midwives cannot really be sure of the child's sex in advance, Guillemeau shifts the emphasis from the hermeneutic challenges of reading biological sex through the mother's body to the inherent difficulty of interpreting the child's body. He relates a story demonstrating that it is difficult to know the sex of a child whose genitals are covered even after birth:

I haue shewed [midwives] a child newly come from the mothers wombe, onely laying my hand vpon the priuie parts, yet durst they not be so bold as giue their opinion thereof, saying, that it were more easie to iudge of it when it was in the wombe, seeing that from thence might be gathered many euident signes: but wee must account the greatest part of them to be vncertain, as we haue formerly said. ${ }^{45}$

Guillemeau's main goal here is to disparage the skill of midwives, but in the process he provides a valuable reminder that before the bodies of children are marked with the social signs of gender, it can in fact be difficult to tell boys and girls apart. Even today, with the excessive gendering of mass-marketed baby clothing and toys, it is not uncommon for strangers to mistake the sex of an infant. The phenomenon of attaching hair bows to the hairless heads of little girls to make sure that their gender is obvious attests to the anxiety that can be caused by the visual indeterminacy of the infant body.

Shakespeare's plays work against this traditional construction of infants as pre-gender. In the context of the tripartite division between men, women and boys that I discussed in my introduction, the presence of girls on Shakespeare's stage would have struck a potentially jarring note since it posited the same kind of developmental trajectory between girls and women as between boys and men. The tripartite model produces an asymmetrical construction of childhood that recognises boyhood, but not girlhood, as a separate phase of life. By representing female infants as inhabiting a specifically gendered space, Shakespeare 
imagines his girls as having childhoods akin to Ariès's specialised boys, thereby participating in a cultural reimagining of girlhood.

III

Pericles (c. 1607-8) was Shakespeare's earliest experiment with staging female infancy, and the presentation of the child Marina during the storm at sea provides an example of both the emotional power evoked by infants as props and the crucial role that language played in establishing female infants as characters rather than objects. By humanising and gendering Marina, Shakespeare sets her apart from the general run of pre-gender, quasi-human infants. The nurse Lychorida carries the infant on stage at the same moment that she announces the mother Thaisa's death, providing Pericles with the dramatic opportunity to convey his sorrow to the audience via the represented infant. In addition to his own grief at the loss of his wife, Pericles calls attention to the hardship of coming into the world under such circumstances. The bundle of blankets, like the infant it represents, is a 'thing' that gets reconstituted as a future human being. Lychorida's language makes this duplicity explicit. 'Here', she laments, 'is a thing too young for such a place ... Take in your arms this piece / Of your dead queen' (11.15-18, my emphasis). As yet unseen by her father, the unnamed infant is merely a 'piece' of its mother, a 'thing' that does not yet have the status of the fully human. In a moment that is extremely moving in performance, Lychorida hands the child to its father, and Pericles initiates the process of transforming the 'thing' from a stage prop to a female character, his 'little daughter' (11.21). His language anthropomorphises the bundle of blankets by crediting it with human needs, such as 'careful nursing' and protection from the elements.

Despite the poignancy of Pericles's speech, however, the infant Marina in Scene 11 functions predominantly as an object for the projection of adults' emotions rather than as a character to whom emotions are ascribed. Pericles emphasises Marina's smallness and vulnerability rather than her gender, perhaps because the script focuses on Pericles's palpable grief for his dead wife Thaisa more than his newly formed relationship with the child. Lychorida immediately identifies the infant as a daughter, but she remains tellingly unnamed. Where the play truly establishes the child as a future human character is in Scene 13, at which point Pericles has had time to bond with her. The infant as prop is once again carried on stage, but this time Pericles emphasises her plight as a female child. Pericles has already taken care of the scene's expositional 
function at the end of Scene 11, where he has announced his intention of leaving Marina in the care of Cleon and Dionyza. The purpose of Scene 13, therefore, appears to be twofold: first, to take advantage of the emotional charge of Pericles's love for his daughter, and second, to further establish the infant daughter as a female character who will later appear on stage. Pericles does this by giving the 'gentle babe' the name of 'Marina' in honour of her birth at sea, by talking about the child as 'she' and by imagining her in the future as having grown up into a woman. Whereas Pericles has previously referred to 'this poor infant' as 'it', he begins in this scene to talk about her as a future adult woman. Pericles requests that the king and queen of Tarsus 'give her princely training, that she may be / Mannered as she is born' (13.16-17); he then vows not to cut his hair until 'she be married' (13.27, my emphasis). I will return again to the significance of referring to a child as 'it' rather than as 'she' or 'he' in my section on The Winter's Tale; the important point to note with regard to Pericles is the way that the father's projection of a future for his daughter establishes Lychorida's 'little mistress' as a future human being - one who will occupy a gender and class position (13.40). The oral scripting of Marina's forthcoming life produces her as an extraordinary infant by initiating her into girlhood during her infancy.

What we see in Shakespeare's staging of female infancy is a reworking of Comenius's woodcut. The gendering of Marina imagines female infancy as a separate stage of childhood. Pericles produces his daughter as a girl, isolating her temporarily from danger and providing a space for her to be 'mannered' as she was born; in effect, he makes Marina into an example of a specialised child. Except for Clarence's daugher in Richard III, Shakespeare does not seem to have staged the transitional period between female infancy and womanhood - a period we might describe today as girlhood - but Gower's speech at the opening of Scene 15 gives us a glimpse into how that transition might have been imagined. Marina's emergence as a young woman or maid gets set up via a narrative of education and training. She has been 'by Cleon trained' in music and letters and has 'gained / Of education all the grace, / Which makes her both the heart and place / Of gen'ral wonder' (15.7-11). Even as Gower contrasts the skilful and beautiful Marina to Cleon and Dionyza's daughter Philoten, he uses the connection between the two to establish Marina as having been transformed from the infant of Scenes 11 and 13 into the young woman of the last part of the play. Because we know the two friends have been raised together, we know that Marina, like Philoten, has grown up. When Gower calls Philoten a 'maid' and 'full-grown lass', he likewise constructs Marina as a maid who is ripe for 
marriage and ready to have adventures of her own. Gower thus prepares the audience for her entrance on stage as a speaking character. She goes from being spoken of as a 'poor infant' by her father to speaking of herself as a 'poor maid, / Born in a tempest' (15.69-70). Having passed through the relatively sheltered stage of girlhood, Marina emerges as a full-grown lass who has gained the skills necessary to function in the adult world. The dangers to which she is exposed do not threaten her until she emerges from the space of childhood.

In Pericles, more so than in the other two plays I discuss, the royal girl's gender fulfils a symbolic function within the play. Ultimately, Marina transforms from being a piece of her mother to being a mother figure herself. When Pericles arrives senseless and unable to speak in Mytilene, Marina recalls him to his senses by telling him her life story. Deanne Williams offers a brilliant reading of the way this scene undoes the patriarchal logic that underpins and in many ways rationalises the incest with which the play begins. In a patriarchal system that treats women as objects of exchange between men, daughters are the property of their fathers, making them logically their fathers' sexual property. ${ }^{46}$ Pericles imagines a different basis for the parent-child relationship, one based on mutual affection and recognition. The play enacts this possibility by having Pericles reverse his paternal role as the begetter of Marina and make himself into her child: ' $\mathrm{O}$, come hither, / Thou that beget'st him that did thee beget' (5.1.194-5). This line reflects both the immediate context of the play in which Marina's tale serves as a regenerative treatment for the ailing king and the larger theory through which parents' children enable them to continue living through the continuation of their seed. The restorative power of Marina's discourse lies not only in her identification with her father's sufferings, but also in his ability to identify with her. Pericles tells Marina that if her grief proves a 'thousandth part' of his, 'thou art a man, and I / Have suffered like a girl' (5.1.131-2). Given the correspondence between the father and daughter's sorrows, it would appear that Pericles has suffered like a girl - like his own daughter, whose hardships he foresaw when he imagined her future as an adult woman.

\section{IV}

Having previously experimented with the presentation of a female infant on stage in Pericles, Shakespeare once again returns to the issue of daughters as royal heirs in The Winter's Tale, a play that even more explicitly establishes the stakes of identifying an infant as a girl. In 
Shakespeare's time, as today, the question of whether a child was male or female was often one of the first asked, and on stage, the answer functioned as a verbal alternative to viewing the child's body. When the Old Shepherd encounters the abandoned Perdita on the Bohemian seacoast, his immediate response is to wonder about the child's biological sex. His phrasing of the question has given rise to a textual crux. He exclaims, 'Mercy on's, a bairn! A very pretty bairn. A boy or a child, I wonder?' (3.3.67-8). Editors disagree about this line, most glossing 'child' as 'girl' with little other explanation. For some, the enigmatic line is taken as a display of the Shepherd's rustic ignorance, since a boy is a child. ${ }^{47}$ However, more recent editors have acknowledged that 'child' was a synonym for 'girl' in some English dialects, a fact that reinforces the sense in which childhood was by definition girlish. ${ }^{48}$

Whether or not the Old Shepherd provides an example of a user of dialect or a misuser of language, he dramatises the moment through which "the mark of gender appears to "qualify" bodies as human bodies' ${ }^{49}$ Identifying the sex of children provides a verbal performance of their interpellation into a gendered subject position long before the infant enters into discourse as a speaking 'I'. In the case of Perdita, the Old Shepherd's question matters precisely because the infant as prop has to emerge later as an embodied female character, a theatrical substitution predicated on an already established gender identity. When the Shepherd poses his question, the audience would already know the answer because Emilia establishes the child's biological sex in Act 2, Scene 2. When Paulina asks if Hermione has been delivered of 'A boy?' Emilia replies, 'A daughter, and a goodly babe, / Lusty, and like to live' (2.2.29-30). Establishing Perdita not only as female but also as 'like to live' provides a stark contrast to the failing health of Mamillius and sets Perdita up to replace Mamillius as the play's central child. Staging the rediscovery of Perdita's girlhood in Act 3 plays a critical role in her translation from Sicilian princess to Bohemian country shepherdess, from the royal 'girl' to the rustic 'child'. This substitution follows a similar one, of the human 'bairn' for the Old Shepherd's lost sheep, which he has been seeking when he finds the child. It is almost as if the Shepherd's identification of the bundle as representing a human being rather than a lost animal depends upon his ability to ask whether it represents a 'boy or a child'.

That said, Shakespeare's contemporaries were apparently much more comfortable than we are with prolonging the time in which infants remained suspended within the position of the unspeaking 'it'. Language registered the gender ambiguities of infancy through the commonplace practice of referring to infants as 'it', regardless of sex. Barbara Traister's 
work with Simon Forman's medical manuscripts has shown that Forman always used the neuter pronoun 'it' to refer to patients under the age of ten. Traister writes, 'He apparently did not think of children as gendered until they approached puberty, when the pronoun by which he referred to them became "he" or "she". ${ }^{50}$ Although not all writers were as consistent as Forman in his linguistic practice, his use of 'it' to refer to infants and very young children was hardly unique. An interesting parallel occurs in Pandosto, when the infant Fawnia's acquisition of human identity is registered in a linguistic shift from 'it' to the gendered pronoun 'she'. Fawnia, Perdita's literary predecessor, enters the narrative through her identification as a 'daughter', and yet Greene's narrator proceeds to refer to 'the child' as 'it' while 'it' remains an infant. When Greene's Shepherd first hears Fawnia crying, he mistakes her sounds for the bleating of a sheep. Like the Old Shepherd in Shakespeare's play, he soon discovers that what he initially thinks is an animal is instead a child dressed in a rich mantle. Greene's character considers carrying 'it' to the king to have 'it' brought up according to 'its' birth (in the manner in which Pericles hopes to have Marina raised), but instead he takes 'it' home to his wife so that they can keep the treasure packaged with the infant. Not until after the Shepherd and his wife have adopted and nourished the child so 'cleanly and carefully as it began to be a jolly girl' does the text switch and begin to refer to Fawnia as 'she'. Like Marina in Pericles, Fawnia's entry into gender marks her entrance into the narrative as a human character, and she becomes, rather than is born, a 'girl'. This transformative moment, when the infant goes from being 'it' to 'she', from a creature to a human being, is symptomatic of the way early modern notions of humanity depended upon constructions of gender. Shakespeare locates Perdita's transformation from 'it' to 'she' at a much younger age than Greene does for Fawnia; Emilia and Paulina engender Perdita with humanity even before she re-emerges on stage as a sixteen-year-old girl.

Whereas the thematic centrality of daughters in Pericles does not explore gender differences between children, the staging of female infancy in The Winter's Tale consciously supersedes the story of boyhood with the story of girlhood. At the beginning of the play, the dialogue focuses on the importance of male childhood friendship before becoming, like Pericles, about the restoration of a wife and daughter. The opening conversation between Camillo and Archidamus emphasises the childhood connection between Leontes and Polixenes, and at the outset, the play appears to be about royal boys. Camillo even calls attention to Leontes's son Mamillius as 'a gallant child; one that, indeed, physics the subject, makes old hearts fresh' (1.1.33). It is not, however, 
Mamillius who will make old hearts fresh; it is Perdita who reintroduces order, health and happiness into the royal family and, by extension, the nation.

The substitution of Perdita for Mamillius may well have been quite literal if the same boy played both roles, ${ }^{51}$ but even without such a staging, the play nonetheless dramatises his displacement. In the scene featuring Mamillius and Hermione's waiting women, Mamillius saucily refuses to play with them. The First Lady tells him, 'The Queen your mother rounds apace. We shall / Present our services to a fine new prince / One of these days, and then you'd wanton with us, / If we would have you' (2.1.17-20). Teasing Mamillius about the possibility that a new 'prince' - a word that could designate a male or female ruler - could replace him, the First Lady jestingly evokes the anxieties of an older child about the birth of a younger one. That replacement is exactly what the play enacts. Perdita's name means 'lost', but she is ultimately recovered, whereas Mamillius's death leads to his permanent loss. His erasure begins with Perdita's birth and becomes complete with the Oracle's pronouncement during Hermione's trial. The prophecy from Delphos makes no mention of Mamillius. It reads, 'Hermione is chaste, Polixenes blameless, Camillo a true subject, Leontes a jealous tyrant, his innocent babe truly begotten; and the king shall live without an heir if that which is lost be not found' (3.2.131-4). As the 'truly begotten babe', Perdita is that which has been lost and that which must be found; in the last acts she becomes a 'princess', writing out the gender-ambiguous term 'prince' and becoming a gender-specific royal heir.

As Susan Snyder has discussed, Leontes's relationship with his son disintegrates with the father's conviction that Mamillius is not his own, leading the disturbed king to wrench him away from his mother and female caretakers in Act 2, Scene 1. That is the last time Mamillius appears on stage, and when we next hear of him, he has given way to the illness that kills him. 'It is almost as if', says Snyder, 'removing him from motherly care takes away his palpable physical reality. ${ }^{52}$ Mamillius's name, of course, derives from mamilla, the breast, indicating the child's bodily dependence on his mother. Although he is five years old and no longer nursing, he remains unbreeched and visibly still under the care of women. Snyder describes the forcible separation of mother and son as an act that helps initiate a gender polarisation in the play, spatially as well as thematically. ${ }^{53}$ By relegating Hermione and her female attendants to prison, Leontes sets up a division between men and women of the court, culminating in a clash between the two sexes at the trial. The effect on Mamillius of this radical breech between the sexes is immediate and, unlike Hermione's death, irreversible. Not yet ready to leave the 
world of female caretaking, he perishes, and is resurrected only in so far as Perdita takes his place.

Whereas traditional readings of the play attribute Leontes's disaffection with Mamillius to anxiety over the impossibility of proving paternity, Robert Reeder has read this resentment as part of a desire to return to childhood. As Mary Ellen Lamb has argued, the scene where Leontes separates mother and son recapitulates the violent rupture in the lives of early modern boys when they were taken from the care of their mother and nurse and thrust into the masculine sphere of education and martial training. ${ }^{54}$ In Reeder's view, Leontes's obsessive need to see himself in his son stems from his jealousy of his son's ability to frisk in the sun and plead 'not guilty' at judgement day. Similar to Reeder's emphasis on patriarchal jealousy of the unbreeched boy is Diane Purkiss's analysis of the compensatory fiction of childhood that little girls offer in Andrew Marvell's poetry. For girls, no absolute break with female caretakers had to take place. She argues that young girls take on a prominent role in Marvell's poetry because they offer a utopian vision of innocence for adult men who have been disillusioned by the violence of the Civil War. ${ }^{55}$ In The Winter's Tale, as in Pericles, a rupture between female child and female caretakers does take place, which complicates the possibility of seeing girlhood as an idealised space of innocence. In fact, Pericles and The Winter's Tale reveal the necessity of rupture to push girls, like boys, into a specialised realm of childhood.

It is my contention that Perdita's role as royal heir facilitates a vision of dynastic descent that can mend patrilineal failure. At a time when James's ascension to the throne promised the restoration of primogeniture to the English monarchy, Shakespeare and his contemporaries would have continued to be aware that an unbroken line of succession from father to son was a monarchical ideal rather than an absolute requirement. Since Henry VIII's death, the country had seen a series of royal daughters in the role of queen, and for all of James's patriarchal propaganda, he claimed his descent from Henry VII through the female line. Like the founding king of the Tudor dynasty, contenders for the throne frequently shored up their claims by marrying royal women, making women in the line of succession one of the ways in which family dynasties could be reshaped to produce the illusion of an unbroken family lineage. It is an often overlooked detail of the Gunpowder Plot that the conspirators supposedly aimed not only to depose James, but to set up his daughter Elizabeth in his stead as a Catholic queen. This seems odd in light of what we know about her Protestant convictions, but it demonstrates the extent to which royal women could open up alternatives to the existing monarchical arrangement. To be clear, I do 
not mean to suggest that The Winter's Tale directly mirrors actual political events; what I mean is that it represents an attempt to come to grips with the reality of patrilineal failure and to imagine an alternative that maintained the possibility of dynastic succession.

\section{V}

The Winter's Tale anticipates the even more unlikely replacement of the story of boyhood with the story of girlhood in Shakespeare and Fletcher's Henry VIII, or All Is True (1613). In this play we have the full flowering of the political connection between royal succession and female children that we see in Pericles and The Winter's Tale. As the story of Henry VIII's quest for a male heir, Shakespeare and Fletcher's play anticipates popular historiography's fascination with the Tudor king's reproductive failures. What differentiates Shakespeare and Fletcher's Henry VIII from his historical model, however, is that the birth of Elizabeth I rather than Edward VI satisfies the king's dynastic ambitions. Instead of dramatising Henry's disappointment that Elizabeth is a girl, the play gives us one of the most curious moments in the Shakespearean corpus. Entering to inform the king of Elizabeth's birth, the Old Lady first announces that the queen has given birth to a boy. The exchange begins with Henry asking:

Is the Queen delivered?

Say, 'Ay, and of a boy.'

The Old Lady replies:

Ay, ay, my liege,

And of a lovely boy. The God of heaven

Both now and ever bless her! 'Tis a girl

Promises boys hereafter.

The Old Lady's figuration of the infant Elizabeth as a girl who promises boys hereafter comes from an early modern adage suggesting that the birth of a girl, while potentially disappointing to parents who wanted a boy, could be encouraging as a sign of the mother's future fertility. ${ }^{56} \mathrm{In}$ this particular case, however, the Old Lady's statement would have been powerfully ironic; the Jacobean audience would have known all too well that Elizabeth's birth did not presage the birth of future sons for her mother Anne Bullen. Moreover, this enigmatic moment marks a turning point within the framework of the play. The Old Lady's rhetorical 
doublespeak effectively erases the futurity implied by the promise of boys and suggests that Elizabeth herself is the desired 'lovely boy'. Enacting a substitution that turns the audience's expectations upside down, the Old Lady verbally presents the infant as male and then regenders the boy as a girl, first referring to 'her' and then positively identifying 'her' as a 'girl'. The effect is to figure Elizabeth as the ideal infant in and of herself. Remarkably, the Old Lady's explanation satisfies Henry, who goes on in the final christening scene to proclaim, 'Never before / This happy child did I get any thing' (5.4.64-5). Explicitly rejecting Mary, Henry might as well add, 'Never again will I get anything', since the play completely eclipses the historical male heir Edward VI.

The Old Lady initiates a shift in the play's focus that culminates in the presentation of the infant Elizabeth on stage during her christening in Act 5 Scene 4. Using the language of nature, Cranmer prophesies that Elizabeth will be the infant-mother whose birth signals the onset of an English golden age:

This royal infant-heaven still move about her-

Though in her cradle, yet now promises

Upon this land a thousand thousand blessings,

Which time shall bring to ripeness ...

Her foes shake like a field of beaten corn,

And hang their heads with sorrow. Good grows with her.

In her days every man shall eat in safety

Under his own vine what he plants and sing

The merry songs of peace to all his neighbours.

This passage celebrates Elizabeth's fertility, not her mother's. Elizabeth will ripen blessings and render the land so fertile that the yield will feed all the English. Her fertility will make all of England fertile, and as she grows, so too will goodness. Although Elizabeth's status as the virgin queen complicates Cranmer's representation - she will, as Cranmer says, die 'yet a virgin' (5.4.60) - he reconciles Elizabeth's virginity with her reproductive capacity by calling her 'the maiden phoenix' out of whose ashes an heir will rise. That heir, of course, is James I, and Cranmer suggests that Elizabeth's legacy gives birth to James as well: 'He shall flourish / And like a mountain cedar reach his braches / To all the plains about him' (5.4.52-4). Like the land that Elizabeth makes fertile and the vines she helps to grow, James is a tree whose growth Elizabeth makes possible. Elizabeth, like Perdita, becomes a symbolic mother, a matriarch who will beget a grand patriarchal future.

From a contemporary perspective, it might be tempting to see the 
development of girlhood as empowering, but as we see with Marina, Perdita and Elizabeth, girlhood resonates in complex ways that cannot be seen as wholly positive or negative. As with the idea of childhood, or what Hugh Cunningham has more accurately called 'the middle-class ideology of childhood', the idea of girlhood came with the isolation of girls into a special category. ${ }^{57}$ When Ariès claimed that the seventeenth century invented the sentiment of childhood, the violent reaction against his argument took as its starting point the assumption that not having a sentiment of childhood necessarily indicated backwardness. But Ariès did not see the development of modern childhood as unequivocally beneficial. The nuclear family, built around the special category of the child, comes at the expense of sociability. The construction of girlhood as a distinct stage of childhood, I would suggest, produced similarly complex results that cannot be boiled down to a teleological historical narrative. Shakespeare's royal girls can play crucial roles in the form of succession, but they do so in the service of re-establishing patrilineal descent. Not only can their reproductive powers be harnessed in the service of the dynasty, so too can their marriages enable a form of royal power sharing, where the father-king and mother-queen can remain the sovereign rulers of one country, while the daughter and her husband take over another. Even as the emphasis shifts, as it does in Cranmer's speech, from biological generation to spiritual engendering, the goal is to pass on the patrilineal right to any potential male heirs, thus making Shakespeare's royal female infants into girls 'who promise boys hereafter'. Shakespeare's girls may join boys in the realm of childhood, but their legitimacy prevents them from challenging the system that accepts them as heirs against its will. As mute, ungendered props, the bundles of blankets that represented infants on stage paradoxically offered the ideal vehicle for imagining a future articulate voice for royal girls. Middleton's middle-class female infants, on the other hand, do not go on to become older female characters, nor do his other characters imagine them as future speaking subjects. Instead, I argue in the rest of this chapter that Middleton stages female infancy to redefine legitimacy not as being born within wedlock but as being integrated into the affective kinship network of the London social community.

\section{$\mathrm{VI}$}

In late January 1613, the Countess of Salisbury, wife of William Cecil, the second Earl of Salisbury and son of Robert Cecil, gave birth to a daughter whose nativity was to become the talk of London society. So 
sumptuous was the Countess's post-partum lying-in that on 4 February 1613 John Chamberlain estimated the value of the goods used to decorate her chamber at 14,000 pounds:

About this day sevenit the Countesse of Salisburie was brought abed of a daughter, and lies in very richly, for the hanging of her chamber, being white satin, embroidered with gold (or silver) and perle is valued at fowreteen thousand pounds. ${ }^{58}$

For the Countess, these rich items of embroidered satin would have been used to make her room into a consecrated space, thus producing an allfemale enclosure that both isolated and elevated her until her churching forty days later. To be able to afford a comfortable, luxurious lying-in was a sign of class status, and editors have traditionally considered the Countess of Salisbury's real-life extravagance to be parodied in the upstart pretentions of Mrs Allwit's expensive confinement in Thomas Middleton's A Chaste Maid in Cheapside. ${ }^{59}$ In contrast to the lying-in, the christening of the infant was a moment at which the mother was absent, taking place as it did within a few days of birth, well before the mother's churching and reintroduction to the community at large. Appointing godparents was the responsibility of the father, a process that is vulgarised in Middleton's play because the wittol Master Allwit seeks out gossips for his wife's bastard child by Sir Walter Whorehound. The christening scene, however, makes an important comment about the way the play constructs infancy, gender and class.

As the central rite of initiation of children into the Church, baptism was a crucial first step in a child's integration into early modern religious and social existence, and it communally staged the infant as a future speaking subject. Godparents promised on behalf of their godchildren that they would forsake the devil and serve God, and when they did so, they spoke in the projected voice of the infant. Like the Catholic liturgy, the English Protestant liturgy was specifically adapted to emphasise the importance of coming to religion as a child. But unlike the Catholic liturgy, the official Protestant baptismal ceremony did not differentiate between the spiritual positions of girls and boys, and it did not include separate prayers for children of different sexes. With the Book of Common Prayer, the long-standing Catholic practice of repeating different prayers for boys and girls was abolished. ${ }^{60}$

At a time when other early modern English cultural sites were registering an increased differentiation between boys and girls (as in Comenius's book), baptism went the other way. In the last version of the Catholic 'Sarum Rite' published before the first Book of Common Prayer, we can see a striking contrast to what would become the English liturgy. As 
E. C. Whitaker suggests, Thomas Cranmer and other English reformers would most likely have worked from the 1543 Rouen edition of Manuale ad usum percelebris ecclesiae Sarisburiensis, translated in 1960 by A. J. Collins. ${ }^{61}$ The Latin Manuale's 'Order for the Making of a Catechumen' begins with the order that the infant should be brought to the church door where the priest should ask the midwife if it is male or female, whether it has been baptised at home, and what name the child is to be called. The 1549 and subsequent editions of the Book of Common Prayer kept the practice of asking the child's name, but it did not include a formal question about the child's biological sex. The Protestant ceremony also did away with the Sarum Rite's specification that male infants be placed on the right side of the priest and female infants on the left. Unlike official English Protestant baptismal ceremonies, theatrical representations of female infants brought questions of gender to the forefront. When characters in early modern drama asked if a child were a boy or a girl, they were in many ways re-establishing a public ritual that no longer had a place at the church door.

Before I turn directly to Middleton's christening scene, I first want to put it into the context of an earlier mock christening scene from Robert Wilson's The Cobbler's Prophecy (printed 1594) that explicitly uses a parody of the baptismal liturgy to pose the question 'Is it a boy or a girl?'. Wilson's allegorical morality play condemns illegitimacy and illustrates the negative consequences of illicit lust on the divine and human worlds. At the centre of the trouble lies the character Contempt, disguised as Content, who wreaks havoc among the gods as well as a set of humans defined by their professions, and Venus, who first betrays Vulcan with Mars and then betrays Mars with Contempt. In retaliation for Venus's wanton behavior, Mercury revokes her title as goddess and curses the child in a parodic inversion of the baptismal blessing. The infant Ruina becomes the allegorical embodiment of the upheaval caused when Mars gets distracted from his divine and moral duties by his affair with Venus. In Mars's absence, the false god Contempt, also Venus's lover, lures characters like Enmius the Courtier into treasonous behaviour, threatening the Duke's realm of Boethia with ruin. The allegorical incarnation of that threat comes in the form of the bastard daughter of Venus and Contempt, carried on stage by two of Venus's maidens, $\mathrm{Ru}$ and Ina. The female infant's birth provides the council of the gods with proof of Venus's doubly adulterous behaviour, cuckolding Vulcan with Mars and then cuckolding Mars with Contempt. Mercury, who serves as the play's principal voice of morality, announces that Venus has been stripped of the title of Goddess and renamed Lust or 'the strumpet Venus'. He then derisively assumes the role of a priest, 
performing a mock baptismal ceremony. Like the priest at the church door, Mercury demands to know the child's sex, her name, and the names of her godmothers and godfather:

Mercury: Whose child is that you beare so tenderly?

$R u$ : My Ladies child, begotten by contempt.

Mercury: $\mathrm{O}$ is it so, and whether beare you it?

Ina: To nurse.

Mercury: To whom?

$R u$ : Vnto securitie.

Mercury: Is it a boy or girle, I praie ye tell?

Ina: A girle it is.

Mercury: Who were the godmothers?

$R u$ : We two are they.

Mercury: Your names I craue.

$R u$ : Mine $\mathrm{Ru}$ and hers is Ina.

Mercury: And whether name I praie yee beares the girle?

Ina: Both hers and mine.

Mercury: And who is godfather?

$R u$ : Ingratitude that is likewise the grandfather.

Mercury: Ruina otherwise called Ruine the child,

Contempt the father, Venus alias lust the mother,

$\mathrm{Ru}$ and Ina the godmother,

Ingratitude the Godfather and grandfather,

And Securitie the nurse,

Heeres a brood that all Booetia shall curse.

Well damsels hie you hence, for one is comming nigh

Will treade your yong one vnder foot. ${ }^{62}$

Although the play's didactic function makes it a foil for Middleton's amoral city comedies, its humanisation of the infant Ruina in a scene following Venus's denunciation reveals how powerfully resonant the Catholic ceremony still was in the 1590s and why the social dramatisation and recognition of the biological sex of infants on stage would still have carried so much symbolic weight. By imitating what usually functioned as an incorporation of an infant into the community, Mercury calls attention to the need for Boethia to curse rather than bless the product of adultery in order to avoid the ruin threatened by the child's name. Mercury has previously put the wheels in motion for Ruina's birth to provoke reform among the gods as well as the citizens of Boethia. He chooses Raph the Cobbler to be his prophetic instrument and sends him on a quest to convey a riddle revealing Venus's betrayal to Mars. Tipped off by Raph, Mars becomes enraged and vows revenge upon Venus and all her kind, including the offspring of her liaison with Contempt. $\mathrm{Ru}$ and Ina flee with their goddaughter to protect the 'yong one' from Mars's wrath. 
Mercury's condemnation of Ruina and her flight strikes a discordant note with the scene's anthropomorphism of the infant. For all that Ruina acts as a material incarnation of Venus's sin, Ru and Ina's description of the 'poore babe' firmly establishes her as more than mere allegory, though her allegorical status makes her anthropomorphism more complicated. Ina calls attention to the hardship on the child of being separated from her mother, tapping into sympathies for her vulnerability, just as Pericles does in Shakespeare's play. The baptismal scene may be tinged with contempt, but in performance, it is hard to imagine that the represented infant would not have elicited a certain amount of pathos. Whatever sins Ruina embodies, the actual exercise of Mars's infanticidal rage would most likely work against the audience's sympathy for the play's moral lesson.

Instead of punishing Venus via Mars's revenge, the play deflects the killing of Venus and her servants, substituting instead a war against the invading troops of Thessaly. With Mars and masculinity restored, the Duke, with the help of Sateros the Soldier, successfully defends Boethia against an attack. Sateros, unlike the other allegorical characters, has seen through Contempt and rejected his offer of patronage, and the war provides him with employment. In the end, Contempt rather than Mars punishes Venus by abandoning her and leaving her alone and miserable, though alive. The allegorisation of the consequences of adultery in the form of a female infant reflects the very real way in which pregnancy could prove that an unmarried woman was no longer a virgin. Giving birth to a child was a tangible way that virginity could be disproved, and the maid whose illegitimate infant cannot be concealed is a common figure in early modern ballads, pamphlets, conduct literature and drama.

Jacobean city comedies, particularly those by Middleton, also frequently take women's chastity as a central theme, and in A Chaste Maid in Cheapside, as well as his play A Fair Quarrel (co-written with William Rowley), Middleton uses the births of female infants to work though questions of adultery in a very different way from Wilson. The staging of female infancy in Middleton actually deprivileges legitimacy as a determining factor of a child's identity. Instead, gender identity signals integration into an affective kinship network and enables integration into the larger social community, enabling the infant on stage to achieve the status of a human.

At the beginning of A Fair Quarrel, Master Russell's speech actually reverses the emotional impulses of primogeniture, which steers parental desire toward sons for economic reasons. Rather than seeing a son as the ideal heir, Russell suggests that the opposite is true. A daughter needs a dowry, whereas a son could be expected to fend for himself: 
... Had I been left

In a son behind me, while I had been here

He should have shifted as I did before him,

Lived on the freeborn portion of his wit;

But a daughter, and that an only one-Oh!

We cannot be too careful o'her, too tender;

'Tis such a brittle niceness, a mere cupboard of glasses,

The least shake breaks or cracks 'em. All my aim is

To cast her upon riches:

$(1.1 .2-10)^{63}$

Having made his fortune on his own merit, Russell would have expected a son to do as he 'did before him'. 'But a daughter', he suggests, has no such recourse. For her, he feels the responsibility to ensure her financial security. His attitude, though solidly merchant class in its relation to men, reflects the viewpoint of the gentry and aristocracy, where marriage becomes a young woman's livelihood; Russell does not consider that his daughter Jane might also make her way via service or apprenticeship, as many middling- and lower-class women did. With Russell's wealth, he has acquired a certain level of blindness about the extent to which women in his own social class participated in the economic realm. Nonetheless, he illustrates a form of fatherly affection that rejects the aristocratic and royal emphasis on producing sons.

Primogeniture might favour sons, but when property was not at stake, there was no material advantage to having a boy rather than a girl. Although demographic statistics about the relative costs of apprenticing a boy and a girl have varied, one source from the late seventeenth century suggests that the cost of raising and training up poor children was the same for both sexes. In 1682, the parish of St Paul's in Covent Garden petitioned the gentry for charitable contributions to supplement a gift from William, Earl of Bedford, so that ten poor children from the parishes of St Martin's, St Giles and St Clement Danes 'shall always have their Breeding, Habit, and placing forth' through the establishment of a charity hospital at High Gate. ${ }^{64}$ Their long-term goal was to establish a hospital of their own, like the one at Christ Church, through which they would be able to maintain a number of poor children, the cost of which they estimated at three pounds yearly per child, 'Boy or Girl', at which rate they estimated that three hundred pounds would maintain a hundred children per year. The petition posited this equality of cost for boys and girls despite openly acknowledging that they would be trained and educated differently:

The Boys shall all be taught to Read, Write, Cast Accounts, some the Rudiments of Navigation, or Learning, if apt unto it, common Painting, 
Planting and Gardening, and other for Drawing, which very many Children are much inclinable to with Pen or Chalk, or else put forth to Handicraft Trades. The Girls, which are the weaker Sex, and have been always less provided for, to Read, Write, Sew, Raise Paste, Still, Dress, and what else may qualifie them for Services.

The historical research of Amy Louise Erickson has likewise called into question the cross-class applicability of the preference for boys, suggesting that procuring a male heir was primarily a concern of aristocrats worried about passing down landed property and titles to male descendants. Erickson's work has shown that for the lower and middling classes, where titles and large amounts of landed property were not at stake, the preference for boys, like arranged marriages, would have been significantly less prominent. ${ }^{65}$ Demographically, she has found that 'prosecutions for infanticide yield no difference in the rate of girls and boys killed at birth, perhaps because the reason for killing an infant was usually illegitimacy'. ${ }^{66}$ Outside of the landed classes, an illegitimate boy was just as much a problem for parents and parishes as an illegitimate girl. In vestry minutes and other parish registers, whether children under the parish's wardship were boys or girls was of little material consequence. The records rarely noted the biological sex of foundling children or the orphans of deceased parishioners except for a few cases in which their names were given. One reason for this omission was that abandoned children were relatively anonymous unless the parents could be discovered. In one exceptional case, a mother who left her child on the Stepney church porch left a note on 'the breast of it, that it was a Christian sole named Jane', in consequence of which the clerk movingly records that the parishioners 'call her Jane'. The Stepney council agreed to provide Jane with a nurse 'for as small a charg as maybe' and to provide her with clothing, but what happened to the infant whose mother wanted to give her a Christian name does not get recorded in the vestry minutes. ${ }^{67}$ Her fate was not uncommon; most foundlings appeared briefly only to disappear into historical obscurity.

Middleton's construction of legitimacy and infancy helps reinsert the Janes of the world into the social fabric. Not infrequently, city comedies rescue female characters by having them marry the fathers of their children, and Middleton uses this device in A Fair Quarrel, actually pushing back the marriage ceremony to before the conception. As previously noted, Master Russell's greatest desire is to match his daughter Jane to a wealthy suitor, to the exclusion of all other factors. He values neither titles nor social position, and as a result favours a marriage between Jane and the wealthy Cornish wrestler Chough. His thwarting of the match between Jane and the socially superior but impoverished Fitzallen 
provokes a crisis because Jane and Fitzallen have secretly been married and conceived a child, whom Jane bears and conceals with the help of a physician and his sister Anne.

Like many children in the early modern archives, the sex of the character Jane's baby is relatively inconsequential. The Dutch Nurse carries the child on stage twice. In its first appearance in Act 3, Scene 2, the Physician and Jane give the child into the care of the Dutch Nurse, passing the child off as the Physician's and pretending that Jane is the godmother. Then in Act 5, Scene 1, the Physician brings the child and Nurse forward to disrupt the marriage ceremony between Jane and Chough. He does so as revenge for Jane refusing his sexual advances after he has helped conceal her pregnancy, and he produces the infant as evidence that Jane is no longer a virgin. Chough and Jane's father interpret the child as absolute proof of Jane's sexual activity, but at no point do any of the characters ask the child's sex; at stake are her sexual continence and the child's legitimacy, not its gender.

That said, the Dutch Nurse, with her accent and foreign vocabulary, reveals that the 'bastard' child (who turns out not to be a bastard) is a girl. Noting with approval the child's beloved status, the Nurse speaks affectionately to her charge, calling it 'my pretty frokin' (3.2.14). From the Dutch vrouwken, a diminutive of frow (woman) created by adding 'kin', 'frokin' surreptitiously identifies the babe-in-arms as female. ${ }^{68}$ Although a minor detail, her presence echoes the emphasis on fatherdaughter attachment in the larger play and helps shift the emphasis away from kinship ties formed through legal and biological ties and those formed through affection.

As a tyrannical father, Russell hardly compares to other Jacobean characters like Sir Alexander Wengrave in The Roaring Girl or Hermia's father in A Midsummer Night's Dream. When the Physician interrupts Jane's marriage to Chough to confront her with her 'bastard' child, Russell immediately overlooks her defiance and takes steps to ensure her marriage to Fitzallen, even before he knows the child is actually Fitzallen's daughter. Indeed, Jane and the other characters seem to fear fatherly retribution (like that of Mercury in The Cobbler's Prophecy), but find instead tender care and understanding (like that of Ru and Ina). When Jane admits to her father, 'it's true, sir, I have a child' (5.1.236), his response sounds absolutely nothing like what Jane seems to have expected. 'Hast thou,' he asks, 'Well, wipe thine eyes, I'm a grandfather then; / If all bastards were banished, the city would be thin / In the thickest term-time' (5.1.236-9). His general affection for his daughter and desire to see her happy take precedence over his sense of fatherly rights; even his earlier greed has been on her behalf rather than part of a plot 
to advance his own interests. Conveniently, the play has it both ways; Fitzallen welcomes the child as his own because it is his own, mitigating the threat that bastardy poses to the social order. However, the fact that Russell's consent was obtained before he learns the truth only heightens the sense that the rigid moral precepts of Wilson's play have no real force in Middleton and Rowley's fictional world.

If A Fair Quarrel works against the sentiments expressed about adultery and illegitimacy in The Cobbler's Prophecy, Middleton goes even further in A Chaste Maid in Cheapside, a play in which bastards are not only beloved but desired. As the last of Middleton's great city comedies, Chaste Maid is the culmination of an authorial project aimed at representing the urban middling class in all its grit and glory. Setting the action in Cheapside, a London space associated with brothels and thievery, Middleton dramatises a world in which chastity, marital fidelity and genealogical legitimacy are the exception rather than the rule. Chaste Maid features no fewer than three on-stage infants, all of which are illegitimate: the child of Touchwood Senior and a character identified only as 'Wench', an infant abandoned in a basket of mutton, and the child of Sir Walter Whorehound and Mistress Allwit. Within the play's framework, infants are the objects that knit together and disrupt the sexual and social kinship networks of the characters. The level of acceptance represented in Chaste Maid may be a little over the top and at times farcical, but the play clearly imagines an early modern world in which legitimacy and gender were valued differently in practice from in theory. The three infants suggest that the biological sex of an infant was important in securing its status as human, but even more important was its social acceptance.

With the exception of the courtship of Moll Yellowhammer by Touchwood Junior, all of the other plots revolve around a crisis of reproduction. In one, Master Allwit serves as a willing cuckold to Sir Walter Whorehound because Sir Walter not only fathers the Allwit children but financially supports the Allwit household. In the other two plots, one couple, Lord Oliver and Lady Kix, face a crisis of infertility, and the other, Touchwood Senior and his wife, face a crisis of over-fertility. The Kixes desperately want an heir, whereas the Touchwoods have been driven into poverty through Touchwood Senior's super-fertility. In both cases, children are aligned with the family's economic prosperity, either via inheritance networks or through the using up of resources. The play mirrors the overabundance of infants in the Touchwood household via the overabundance of infants carried on the stage.

For the most part, children in this play are not quite fully human; they're either conduits for land and money, like the Allwit children, 
or they're animalistic and inhuman. In a scene that makes explicit the close connection between children and animals, two promoters seek to enforce the statutes forbidding the consumption of animal flesh during Lent. They do so selectively, depending on whose masters and mistresses have offered them bribes. The corrupt promoters patrol the streets of London in search of illicit meat-laden packages that they can confiscate and consume themselves, in defiance of the very statute they are charged with upholding. Their corruption comes back to haunt them when they take a basket from a woman who has concealed her illegitimate child under a loin of mutton. ${ }^{69}$ Using the promoters' greed to trick them into commandeering the basket from her while she supposedly goes to get proof that her mistress is sick and has a dispensation to enjoy the mutton, she secures their promise to keep the basket until she returns. Enthusiastically feeling what he initially believes to be a lamb's head, the second promoter is struck with rage upon discovering that the meat he has promised to keep is in fact the woman's baby. As in historical records concerning abandoned children, which rarely noted the sex of foundling children, the biological sex of the infant is not mentioned. As an animal-like thing that circulates across the stage, the infant lies outside both the legal boundaries of marriage and the affective ties of kinship. Its biological sex is consequently left unspecified. Keeping a boy would be no less onerous to the promoters than keeping a girl.

A similar incident, probably inspired by or inspiring of Middleton's scene with the promoters, occurs in John Fletcher's The Chances. Although it involves a boy child, the scene reveals the close association between infants and objects and reflects the general view of children as financial burdens that we see in Chaste Maid. When a woman mistakes Don John for a man named Fabrizio with whom she has an appointment, Don John seizes the opportunity to take control of the package she seeks to hand off. When he re-enters a few scenes later, he reveals that he has accepted not a valuable package, but a costly abandoned child. In Act 1, Scene 5, Don John is crucially uninterested in the infant's biological sex. The child's presentation as a child rather than a package does not include the presentation of its gender. Not until Act 3, Scene 3 does the play reveal the infant to be a 'brave Boy' (3.3.53), a detail that makes very little material difference within the play's fictional narrative. The child's status as a boy enables his mother Constantia to identify him as hers, but neither she nor any of the other characters are concerned about the child's biological sex per se. No sense of the child as a future male emerges, probably because the play ends before he grows up. The play neither stages him as a character in himself nor imagines his transition from boy to man. 
Like the promoters, Don John initially views the child principally as a financial burden and describes it in metaphors of foodstuff. It is 'a lumpe got out of lazinesse' that he addresses as 'good white bread' and a 'Ginger-bread', one of a 'beavy of these Butter prints', one of 'other mens adulteries' who will now cost Don John a good deal in charity (1.6.11, $26,23,29) .{ }^{70}$ In contrast to the promoters, however, he does not plan to abandon the child and instead acknowledges his responsibility for it:

... to leave it here were barbarous,

And ten to one would kill it: a more sin

Then his that got it: well, I will dispose on't,

And keep it, as they keep deaths heads in rings,

To cry, memento to me; no more peeping.

Now all the danger is to qualifie

The good old gentlewoman, at whose house we live,

For she will fall upon me with a Catechisme

Of foure houres long: I must endure all;

For I will know this mother: —Come good wonder,

Let you and I be jogging: your starv'd treble

Will waken the rude watch else:

As I will show with the Allwit child in Chaste Maid, what enables the food-like infant to go from being a mere object to a child (though not a full character) is the willingness of the community to care for it. Unlike the unfortunate foundling in Chaste Maid, this child will be taken in, raised and eventually given a social and gender identity. It does not happen within the play, but the eventual reconciliation of Constantia with the Duke and their marriage point towards a future integration into and participation in human relations.

Until endowed with an individual identity and marked as human, infants circulate on the stage either as objects of projected emotions or as objects of exchange. The baby in the basket in Chaste Maid is in many ways interchangeable with the other unsexed infant in the play, the child whose mother describes it as the 'workmanship' of Touchwood Senior (2.1.65). ${ }^{71}$ The same blankets could be used for both, and, as with the promoters, the central focus is not on the child as a child but on the child as an expensive piece of flesh. Touchwood buys his way out of the situation by offering the woman, identified in the speech prefix as 'Wench', a lump sum to discharge his responsibility. In the process, he casts doubt over whether the woman's infant can be seen as fully human: 'Do but in courtesy, faith, wench, excuse me / Of this half yard of flesh, in which I think it wants / A nail or two' (2.1.83-5). By intimating that the infant has a bodily deformity, Touchwood Senior refuses initially to recognise 
the child as his because he refuses to recognise it as human. The irate mother, however, insists that 'it hath right shape, and all the nails it should have', but the infant never becomes unproblematically human. The Wench reveals before she leaves the stage that Touchwood Senior is the fifth man who has paid her money to support the child, casting the infant as a device that facilitates the circulation of money rather than as a future human being.

The only child in the play referred to as 'she' rather than 'it' is the daughter of Sir Walter and Mistress Allwit, an infant whose place (albeit illegitimate) within the play's kinship network enables her to be imagined as a future human being. Whereas the other two infants could have appeared identical on stage, the Allwit baby would probably have been materially differentiated. Given the lavish nature of the christening, this infant would most likely have been presented as wrapped in an expensive bearing cloth. Although every bit as illegitimate as the other two infants, this one occupies a legitimate space within the affective relationships of the characters. Sir Walter seems genuinely proud of his offspring, so much so that the willing cuckold Allwit congratulates him on having 'a goodly girl', one that the wet nurse describes as superior to her older brothers: 'They're pretty children both,' she says, 'but here's a wench / Will be a knocker' (2.2.25-6). Tellingly, Allwit talks about this wellcared-for child as 'she': 'She looks as if she had two thousand pound to her portion / And run away with a tailor' (2.2.13-14). Imagining the girl as a future woman, Allwit invests her if not with humanity, at least with the potential to become human.

The lying-in scene featuring Mistress Allwit with her gossips in Chaste Maid explicitly stages the conceptual difference between conceiving of a child as 'it' and conceiving of a child as 'she', illustrating the peculiar ability of infants to move back and forth between the two:

2 Gossip: Bring the child hither Nurse; how say you now

Gossip, is't not a chopping girl, so like the father?

3 Gossip: As if it had been spit out of his mouth,

Eyed, nosed and browed as like a girl can be,

Only indeed it has the mother's mouth.

Although clearly identifying the infant as female by calling her a 'girl', the two gossips resolutely figure the child as 'it'. A moment later, however, during a disagreement about whether the infant is large or small, their rhetoric shifts and they begin to refer to the child as 'her', a shift signalling that they are imagining the child as a 'woman' rather than an infant: 
3 Gossip: 'Tis a large child, she's but a little woman.

1 Puritan: No believe me, a very spiny creature, but all heart,

Well mettled, like the faithful to endure

Her tribulation here, and raise up seed.

Not until the gossips begin to project a future adulthood for the infant do their pronouns shift; they switch from 'it' to 'she' to represent the child as a 'little woman' who will go on to become a big woman. In the process, they manage to gender and anthropomorphise the female infant, even as they simultaneously see her as a 'creature'. Just as in Shakespeare and Fletcher's Henry VIII when the Old Lady takes advantage of the gender ambiguity of infancy to label Elizabeth 'a lovely boy', the gossips reveal the capacity for infants to move across the borders that mark off the male from the female and the human from the not-yet human.

We need further demographic and historical studies to know more about early modern attitudes and practices, but in the imaginative space of the Jacobean theatre, there is no question that a project was under way to construct female infants as both desirable and, in some cases, preferable to male infants. These plays counteract any tendency to assume that the default sex of newborn children would have been imagined as male, and they also challenge our existing assumptions about the relative values placed on girls and boys in early modern culture. These plays offer alternatives to the kinship networks privileged under primogeniture. Nonetheless, if achieving humanity depended upon having a gender identity, gender was far from being a guarantor of humanity. Given that women, like children, were often excluded from the status of the fully human and associated with silence and animality, the acquisition of gender placed these female infants in a complicated position; it enabled them to occupy the space of the future speaking 'I', but that space was one that required them to continue to negotiate their identities as girls, damsels, wenches and women.

\section{Appendix: Infants Appearing on Stage, 1540-1642 72}

Date of First Author

Production

1540

1559

1588
Sixtus Birck

John Phillip

Thomas Hughes et al.
Title

Infant's Sex

Sapientia Solomonis

Pacient and Meeke

Grissill

The Misfortunes of Unspecified Arthur
2 Boys

Boy and Girl 


\begin{tabular}{|c|c|c|c|}
\hline $\begin{array}{l}\text { Date of First } \\
\text { Production }\end{array}$ & Author & Title & Infant's Sex \\
\hline 1590 & Robert Wilson & The Cobbler's Prophecy & Girl \\
\hline 1591 & George Peele & Edward I & Boy \\
\hline 1592 & William Shakespeare & Titus Andronicus & Boy \\
\hline 1594 & Anonymous & $\begin{array}{l}\text { Alphonsus, Emperor of } \\
\text { Germany }\end{array}$ & Boy \\
\hline 1596 & George Chapman & $\begin{array}{l}\text { The Blind Beggar of } \\
\text { Alexandria }\end{array}$ & Unspecified \\
\hline 1600 & $\begin{array}{l}\text { Henry Chettle, Thomas } \\
\text { Dekker and William } \\
\text { Haughton }\end{array}$ & Patient Grissill & Boy and Girl \\
\hline 1600 & $\begin{array}{l}\text { Thomas Heywood and } \\
\text { William Rowley }\end{array}$ & The Thracian Wonder & Boy \\
\hline 1600 & Anonymous & Tom a Lincoln & 2 Boys \\
\hline 1600 & Anonymous & $\begin{array}{l}\text { The Weakest Goeth to } \\
\text { the Wall }\end{array}$ & Boy \\
\hline 1602 & Thomas Heywood & $\begin{array}{l}\text { The Royal King and the } \\
\text { Loyal Subject }\end{array}$ & Boy \\
\hline 1607 & $\begin{array}{l}\text { John Day, William Rowley } \\
\text { and George Wilkins }\end{array}$ & $\begin{array}{l}\text { The Travels of the Three } \\
\text { English Brothers }\end{array}$ & Boy \\
\hline 1608 & Thomas Dekker & The Bloody Banquet & 2 Boys \\
\hline 1608 & $\begin{array}{l}\text { William Shakespeare and } \\
\text { George Wilkins }\end{array}$ & Pericles & Girl \\
\hline 1608 & William Rowley & $\begin{array}{l}\text { The Shoemaker A } \\
\text { Gentleman }\end{array}$ & Boy \\
\hline 1609-11 & William Shakespeare & The Winter's Tale & Girl \\
\hline 1610 & Thomas Heywood & The Golden Age & Boy \\
\hline 1611 & Thomas Heywood & The Silver Age & Boy \\
\hline 1613 & Thomas Middleton & $\begin{array}{l}\text { A Chaste Maid in } \\
\text { Cheapside }\end{array}$ & $\begin{array}{l}1 \text { Girl, } 2 \\
\text { Unspecified }\end{array}$ \\
\hline 1613 & Fletcher Field & $\begin{array}{l}\text { Four Plays or Moral } \\
\text { Representations in One }\end{array}$ & Unspecified \\
\hline 1613 & $\begin{array}{l}\text { William Shakespeare and } \\
\text { John Fletcher }\end{array}$ & $\begin{array}{l}\text { Henry VIII, or All Is } \\
\text { True }\end{array}$ & Girl \\
\hline 1614 & John Webster & The Duchess of Malfi & Boy \\
\hline 1616 & $\begin{array}{l}\text { Thomas Middleton and } \\
\text { William Rowley }\end{array}$ & A Fair Quarrel & Girl \\
\hline 1617 & John Fletcher & The Chances & Boy \\
\hline 1618 & $\begin{array}{l}\text { John Fletcher, Nathan } \\
\text { Field and Phillip } \\
\text { Massinger }\end{array}$ & The Knight of Malta & Boy \\
\hline 1624 & $\begin{array}{l}\text { John Webster and William } \\
\text { Rowley }\end{array}$ & A Cure for a Cuckold & Boy \\
\hline 1624 & Thomas Drue & $\begin{array}{l}\text { The Life of the Duchess } \\
\text { of Suffolk }\end{array}$ & Boy and Girl \\
\hline 1624 & Anonymous & The Tragedy of Nero & Unspecified \\
\hline 1624 & Philip Massinger & The Unnatural Combat & 2 Boys \\
\hline
\end{tabular}




\begin{tabular}{|c|c|c|c|}
\hline $\begin{array}{l}\text { Date of First } \\
\text { Production }\end{array}$ & Author & Title & Infant's Sex \\
\hline 1625 & William Sampson & $\begin{array}{l}\text { The Vow Breaker, or the } \\
\text { Fair Maid of Clifton }\end{array}$ & Girl \\
\hline 1627 & Thomas Newman & The Andrian Woman & Boy \\
\hline 1632 & John Ford & Love's Sacrifice & 3 Unspecified \\
\hline 1632 & Ben Jonson & The Magnetic Lady & Boy \\
\hline 1634 & Thomas Heywood & A Maidenhead Well Lost & Boy \\
\hline 1642 & Francis Jaques & The Queen of Corsica & Boy \\
\hline
\end{tabular}

\section{Notes}

1. Anne Varty relates the story of a crying infant actor disrupting an 1867 performance of The Double Marriage. The child's ill-timed screams ruined Ellen Terry's most dramatic moment in the play. See Varty, 'The Rise and Fall of the Victorian Stage Baby', New Theatre Quarterly (2005), pp. 218-19.

2. On the difference between early modern and realist theatres, see Alan C. Dessen, Elizabethan Stage Conventions and Modern Interpreters (Cambridge: Cambridge University Press, 1984) and Recovering Shakespeare's Theatrical Vocabulary (Cambridge: Cambridge University Press, 1995).

3. Early modern audiences would also have been less likely to worry about the ethics of child labour. Theatre historian Thomas Edgar Pemberton has described the Victorian conundrum over staging infancy as follows: 'Babies are always dangerous elements in plays, and are far more likely to provoke laughter than sympathy from the curiously mixed audiences that will always be found within the walls of a theatre. If they are "real live" babies, they are (poor little things) apt to cry at the wrong moments; if they are dolls, they are absurdities.' Quoted in Varty, 'Rise and Fall', p. 218. The success with which many contemporary productions stage Shakespeare's plays without 'real live' babies suggests that the efficacy of dolls depends upon the skill of the performers.

4. See Varty for an account of the way these challenges, particularly concerns over child labour, eventually led to 'real live' babies being replaced by parodic adult impersonations of infancy on the Victorian stage.

5. The only exception that I have discovered in which a live infant was used in early modern drama is a January 1565 performance at court of Sixtus Birck's Sapientia Solomonis that was put on for Queen Elizabeth and the visiting Princess Cecelia of Sweden. The production was notable for its lavish expense, including a payment to the woman who looked after the child. See Elizabeth Rogers Payne (ed.), Sapientia Solomonis, Acted Before the Queen by the Boys of Westminster School (New Haven: Yale University Press, 1938). The performers were likely inspired to bring in the live child because the play features the biblical episode where Solomon is called upon to judge the true mother of an infant who has been exchanged 
for the dead child of another woman. For a critical discussion of the play, see Michael Shapiro, 'The Westminster Scholars' Sapientia Solomonis as Royal Gift Offering', in Paul Menzer (ed.), Inside Shakespeare: Essays on the Blackfriars Stage (Susquehanna: Susquehanna University Press, 2006), pp. 118-31.

6. Sophie Oosterwijk explores the multiple kinds of props that the drama of the Middle Ages may have used in 'Of Mops and Muppets: The Ambiguous Use of the Word "Mop" in the Towneley Shepherds Plays', Notes and Queries 44 (1997), pp. 169-71. W. L. Hildburgh recognises that dolls of some kind must have had to be substituted for children and suggests that the players used alabaster carvings. See his 'English Alabaster Carvings as Records of Medieval Religious Drama', Archaologia 93 (1949), pp. 51-102. M. D. Anderson, on the other hand, points out that some form of stuffed dummy must have been used in dramas featuring Herod, where children were pierced with spears as part of the massacre of the innocents: Drama and Imagery in English Medieval Churches (Cambridge: Cambridge University Press, 1968), p. 18. One further indication of the options available comes from the Livre du Régisseur from Mons, where a wooden child was used to represent Herod's infant son. See Oosterwijk, p. 170; Hildburgh, p. 61; Anderson, p. 133. Early modern evidence is likewise fairly scarce, but a translation by Barnabe Googe includes the detail that on Christmas Day in Italy, 'a woodden childe in clowtes is on the aultar set' to represent the Christ Child. Thomas Naogeorgus, The Popish Kingdome, trans. Barnabe Googe (London, 1570), sig. Dir.

7. Erica Fudge, 'Calling Creatures by their True Names: Bacon, the New Science and the Beast in Man', in Fudge, Ruth Gilbert and Susan Wiseman (eds), At the Borders of the Human: Beasts, Bodies and Natural Philosophy in the Early Modern Period (New York: St. Martin's Press, 1999), p. 104.

8. Erica Fudge, Brutal Reasoning: Animals, Rationality, and Humanity in Early Modern England (Ithaca: Cornell University Press, 2006), pp. 41-2.

9. On the importance of father-daughter relations, see D. W. Harding, 'Father and Daughter in Shakespeare's Last Plays', Times Literary Supplement (30 November 1979), pp. 59-61, and Sharon Hamilton, Shakespeare's Daughters (Jefferson, NC: McFarland, 2003). Marjorie Garber offers an important psychoanalytical account in Coming of Age in Shakespeare (New York: Routledge, 1997), particularly for Marina and Perdita.

10. I am reluctant to draw any definitive conclusions from these statistics because the sample is small enough that infants in lost plays could significantly change the picture. Moreover, in some cases the biological sex of the represented infants was determined by historical personages, as in George Peele's Edward I, John Webster's The Duchess of Malfi and Thomas Drue's The Life of the Duchess of Suffolk.

11. I take my details about the correspondence between Shakespeare's life and the late plays, as well as between those and the Stuart royal family, from David Bergeron, Shakespeare's Romances and the Royal Family (Lawrence: University of Kansas Press, 1985), pp. 5-6, p. 8, p. 10, pp. 38-9, p. 160.

12. Richard Wheeler offers a sophisticated reflection on the possibilities for including Shakespeare's biographies in 'Deaths in the Family: The Loss of 
a Son and the Rise of Shakespearean Comedy', Shakespeare Quarterly 51 (2000), pp. 127-53. What makes Wheeler's integration of biography and textual interpretation impressive is that he incorporates his knowledge of Shakespeare's life into sustained readings of Shakespeare's comedies rather than simply pointing out correspondences.

13. Both Wheeler and Stephen Greenblatt briefly point to the possibility that Mamillius reflects Shakespeare's lost son. See Wheeler, 'Deaths in the Family', p. 153, and Greenblatt, Will in the World (New York: Norton, 2004), pp. 290-1.

14. Glynne Wickham offers one of the most sustained readings of the romances as reflective of contemporary politics, identifying various characters with historical figures from the Stuart family. See his 'Romance and Emblem: A Study in the Dramatizing Structure of The Winter's Tale', in David Galloway (ed.), Elizabethan Theatre III (Toronto: Macmillan, 1973), pp. 82-99; 'The Winter's Tale: A Comedy with Deaths', in Shakespeare's Dramatic Heritage (London: Routledge, 1969), pp. 249-56; 'The Dramatic Structure of Rehabilitation in Shakespeare's Henry VIII', Proceedings of the British Academy 70 (1984), pp. 149-66.

15. See Bergeron, Shakespeare's Romances, pp. 27-72.

16. For an account of the way Protestants used the image of Princess Elizabeth, both before and after her marriage to Frederick of Bohemia, see Georgiana Zeigler, 'Devising a Queen: Elizabeth Stuart's Representation in the Emblematic Tradition', Emblematica: An Interdisciplinary Study of Emblem Studies 14 (2005), pp. 155-79. See also Frances Yates, Majesty and Magic in Shakespeare's Last Plays (Boulder, CO: Shambhala, 1978), p. 59 .

17. Bergeron, Shakespeare's Romances, p. 23.

18. See note 5 in my Introduction.

19. Juliet Dusinberre, 'Boys Becoming Women in Shakespeare's Plays', Shakespeare Studies 36 (1998), pp. 1-28. For similar reasons, Catherine Belsey and Alice Clark agree. See Belsey, 'Disrupting Sexual Difference: Meaning and Gender in the Comedies', in John Drakakis (ed.), Alternative Shakespeares (London: Methuen, 1985), pp. 166-90; Alice Clark, Working Life of Women in the Seventeenth Century (London: Routledge, [1919] 1982), pp. 2-3.

20. Stephen Greenblatt, 'Fiction and Friction', in R. S. White (ed.), Twelfth Night (New York: St. Martin's Press, 1996), pp. 92-128.

21. Thomas Laqueur, Making Sex: Body and Gender from the Greeks to Freud (Cambridge, MA: Harvard University Press, 1990).

22. Greenblatt, 'Fiction and Friction', p. 117.

23. Ibid. p. 94, emphasis in original.

24. Ibid. p. 117. For critiques of Greenblatt that challenge his heteronormative vision of Renaissance sexuality, see Michaela Röll, “"Three”-floating Sexuality: Viola's Identity in Shakespeare's Twelfth Night', The Upstart Crow (1998), pp. 39-55, and Laurie Shannon, 'Nature's Bias: Renaissance Homonormativity and Elizabethan Comic Likeness', Modern Philology 98 (2000), pp. 183-210.

25. Mark Johnston, 'Prosthetic Absence in Ben Jonson's Epicoene, The 
Alchemist, and Bartholomew Fair', English Literary Renaissance 37:3 (2007), pp. 401-28.

26. Luce Irigaray, 'The Power of Discourse and the Subordination of the Feminine', in Margaret Whitford (ed.), The Irigaray Reader (Oxford: Blackwell, 1991), p. 119.

27. Janet Adelman, 'Making Defect Perfection: Shakespeare and the One-Sex Model', in Viviana Comensoli and Anne Russell (eds), Enacting Gender on the English Renaissance Stage (Urbana: University of Illinois Press, 1999), p. 40.

28. Dympna Callahan, Shakespeare Without Women: Representing Gender and Race on the Renaissance Stage (London: Routledge, 2000).

29. Judith Butler, Undoing Gender (New York: Routledge, 2004), p. 11.

30. Ibid. p. 20.

31. Ibid. p. 11.

32. Thomas Hughes, The Misfortunes of Arthur, in Certaine deu[is]es and shewes presented to her Maiestie by the gentlemen of Grayes-Inne at her Highnesse court in Greenewich, the twenty eighth day of Februarie in the thirtieth yeare of her Maiesties most happy raigne (London, 1588), sig. Er.

33. Alphonsus, Emperor of Germany (London, 1654), attributed to George Chapman on the title page.

34. The Tragedie of Nero (London, 1624), sig. E3.

35. John Phillip, The Comodye of Pacient and Meeke Grissill (London, 1569), and Henry Chettle, Thomas Dekker and William Haughton, The Pleasant Comodie of Patient Grissill (London, 1603).

36. George Chapman, The Blinde Begger of Alexandria (London, 1598).

37. Thomas Heywood, A Pleasant Comedy, called a Mayden-head Well Lost (London, 1634).

38. John Webster and William Rowley, The Thracian Wonder (London, 1661).

39. Tom a Lincoln, Malone Society Reprints (Oxford: Oxford University Press, 1992).

40. The Weakest Goeth to the Wall (London, 1600).

41. For an account of Comenius's life and influence on the history of children's education, see Ernest M. Eller's introduction to Comenius's School of Infancy (Chapel Hill: University of North Carolina Press, 1956).

42. By sexual differences, I mean to indicate bodily differences as they were mediated through social and cultural representations. By gender differences, I mean traits and behaviours constructed as belonging to girls and boys and women and men. Although I am aware that recent theorists have raised questions about whether a strict separation between sex and gender can be maintained, I find this separation to be useful for the discussion of early modern infants because the social markers of gender that we have come to take for granted were not then legible in infants.

43. Anne Buck argues that our impression of the widespread indeterminacy of children's sex in early modern paintings has been exaggerated by our unfamiliarity with some of the more subtle gender markers of children's costume. See her Clothes and the Child: A Handbook of Children's Dress in England 1500-1900 (New York: Holmes \& Meier, 1996), p. 17, pp. 59-60, p. 81, pp. 149-50. For more on the differences between the dress 
of unbreeched boys and girls, see Jan Baptist Bedaux and Rudi Ekkart (eds), Pride and Joy: Children's Portraits in the Netherlands 1500-1700 (Amsterdam: Ludion Press, 2000), and Karin Calvert, Children in the House: The Material Culture of Early Childhood, 1600-1900 (Boston: Northeastern University Press, 1992), pp. 42-7.

44. Jacques Guillemeau, Child-birth, or The Happy Deliverie of Women (London, 1612), sig. A4v.

45. Ibid. sig. A4v-Br.

46. Deane Williams, 'Papa Don't Preach: The Power of Prolixity in Pericles', University of Toronto Quarterly: A Canadian Journal of the Humanities 71 (2002), pp. 595-622.

47. This is the opinion of Robert Nares in A Glossary, or Collection of Words, Phrases, Names and Allusions to Customs, Proverbs, etc., Which Have Been Thought to Require Illustration, in the Works of English Authors, Particularly Shakespeare and His Contemporaries (London: Reeves and Turner, 1888), p. 158.

48. J. H. P. Pafford and Stephen Orgel, the editors of the Oxford and Arden editions, cite as evidence the following line from Robert Greene's James IV (1598): 'Whilst Hob your son, and Sib your nutbrowne childe' (5.4.103). As Pafford writes, 'childe' here 'certainly means daughter', and he further points out, following C. T. Onions, that Shakespeare always uses ' $m y$ child' to refer to daughters rather than sons. As the author of Pandosto (1588), on which Shakespeare's play is based, Greene offers a particularly instructive source. That Shakespeare's 'child' appears closely with 'bairn', another term from a regional dialect, makes it all the more likely that he is using 'child' to mean 'girl'. See The Winter's Tale, ed. Stephen Orgel (Oxford: Oxford University Press, 1996), n. 69, and The Winter's Tale, ed. J. H. P. Pafford (London: Thomas Nelson and Sons, 1999), n. 70. Orgel is following the notes to Pafford's 1963 edition. Pafford locates the dialect as belonging to the Midlands and southwest of England.

49. Judith Butler, Gender Trouble: Feminism and the Subversion of Identity (New York: Routledge, 1990), p. 142.

50. Barbara Howard Traister, The Notorious Astrological Physician of London: Works and Days of Simon Forman (Chicago: University of Chicago Press, 2001), p. 65.

51. See Richard Proudfoot, 'Verbal Reminiscences and the Two Part Structure of The Winter's Tale', Shakespeare Survey 29 (1976), pp. 67-78.

52. Susan Snyder, 'Mamillius and Gender Polarization in The Winter's Tale', Shakespeare Quarterly 50 (1999), p. 1.

53. Snyder works out Mamillius's age by pointing out that he is the same age as Florizel, who is twenty-one in the second half of the play. If sixteen years have passed, Mamillius would then have to be five years old at the beginning. See Snyder, 'Mamillius and Gender Polarization', p. 2.

54. Mary Ellen Lamb, 'Engendering the Narrative Act: Old Wives' Tales in The Winter's Tale, Macbeth, and The Tempest', Criticism 40 (1998), pp. 529-53.

55. Diane Purkiss, 'Marvell, Boys, Girls and Men: Should We Worry?', in Naomi J. Miller and Naomi Yavneh (eds), Gender and Early Modern Constructions of Childhood (Aldershot: Ashgate, 2011), pp. 181-92. 
56. Sara Mendelson and Patricia Crawford have found examples of seventeenth-century parents expressing similar sentiments. Thomas Chichely, for example, wrote to his daughter upon the birth of a girl in 1671, 'Although it be a girl that God hath sent ... I remember a saying of your Grandfather Russell who said in time it would [turn?] to a boy.' Mendelson and Crawford cite two other examples of parents consoling themselves for not having a boy by seeing the girl as evidence of fertility: Hannah Brograve and Anne D'Ewes. See Mendelson and Crawford, Women in Early Modern England, 1550-1720 (Oxford: Oxford University Press, 1998), p. 81.

57. See Hugh Cunningham, Children and Childhood in Western Society since 1500 (New York: Longman, 1995), p. 41. As discussed in my introduction, Cunningham's definition of a middle-class ideology of childhood consists of 'a firm commitment to the view that children should be reared in families, a conviction that the way childhood was spent was crucial in determining the kind of adult that the child would become, and an increasing awareness that childhood had rights and privileges of its own'.

58. Quoted in Thomas Middleton, A Chaste Maid in Cheapside, ed. Alan Brissenden (London: A \& C Black, [1630] 2002), p. xiii.

59. For a richly textured account of the connection between the fictional lyingin and the Countess's, see Janelle Day Jenstad, 'Lying-in Like a Countess: The Lisle Letters, the Cecil Family, and A Chaste Maid in Cheapside', Journal of Medieval and Early Modern Studies 34 (2004), pp. 373-403.

60. My attention was first called to this fact by Sara Mendelson and Patricia Crawford's Women in Early Modern England. They suggest that the institution of a single baptismal ceremony affirmed the doctrine that the soul had no biological sex, citing C. Peters, 'Women and the English Reformation', unpublished paper, 'Women, Text and History' seminar, Oxford, 15 May 1990. See their chapter on 'Childhood and Adolescence', p. 81, n. 17. For an account of the medieval baptismal practices from which the English Church formed its revised ceremony, including information about gender distinctions made during christening, see Nicholas Orme, Medieval Children (New Haven: Yale University Press, 2001), pp. 27-9.

61. 'The Sarum Rite', in E. C. Whitaker (ed.), Documents of the Baptismal Liturgy, trans. A. J. Collins (Collegeville, MN: Liturgical Press, 1960), p. 284.

62. Robert Wilson, The Coblers Prophesie (London, 1594), sig. Fr.

63. All references to this play are to the New Mermaids edition: Thomas Middleton and William Rowley, A Fair Quarrel, ed. R. V. Holdsworth (London: Ernest Benn Limited, [1617] 1974).

64. An humble request to the honourable charitable gentry of St. Pauls CoventGarden, with other great and noble persons, ladies, gentry, and wellwishers to the numerous poor children in St. Martins, St. Giles's, and St. Clements Danes, in the county of Middlesex (London, 1682).

65. Amy Louise Erickson, Women and Property in Early Modern England (New York: Routledge, 1993).

66. Ibid. p. 49.

67. Memorials of Stepney Parish, ed. G. W. Hill and W. H. Frere (Guildford: Billing \& Sons, 1890), p. 7. 
68. For another example, see Thomas Dekker's reference to 'a little Frokin (one of my Dutch runnawayes children)' in his 1603 Wonderfull Yeare. The editor of the New Mermaids edition claims that 'frokin' could be applied to children of either sex, but Grzegorz Kleparski, who has made an extensive study of early modern synonyms for 'girl', classifies the term as definitively gendered female. See his Theory and Practice of Historical Semantics: The Case of Middle English and Early Modern English Synonyms of Girll Young Woman (Lublin: University Press of the Catholic University of Lublin, 1997). My own opinion concurs with Kleparski's.

69. This scene has obvious connections to The Second Shepherds' Play from the Towneley cycle, where Mak and his wife Gill attempt to disguise a stolen sheep as their infant and, when discovered, claim he is a changeling misshapen by fairies. Whereas Middleton's promoters mistake a child for a lamb (albeit a dead one), the shepherds in the medieval play initially mistake a lamb for a child. As a point of interest, the Second Shepherd, despite his distress over his lost sheep, takes the time to ask Mak if his child is a boy ('knave').

70. This and all other references to this play are from John Beaumont and John Fletcher, The Chances, in Fredson Bowers (ed.), The Dramatic Works in the Beaumont and Fletcher Canon, Vol. IV (Cambridge: Cambridge University Press, 1979), pp. 541-645.

71. This and all other Chaste Maid references are to the New Mermaids edition: Thomas Middleton, A Chaste Maid in Cheapside, ed. Alan Brissenden (London: A \& C Black, [1630] 2002).

72. In this appendix I am using, when available, the date of likely first production from the Database of Early English Playbooks at <http://deep.sas. upenn.edu/index.html> (accessed 12 July 2012). 


\section{Where Are the Girls in English Renaissance Drama?}

When I first started working on girlhood, I shared with other scholars the belief that, with one or two exceptions, young female children did not appear as characters in English Renaissance drama. Although I was arguing for a more expansive definition of who counted as a 'girl', I had a lingering sense of unease when other scholars would ask, 'Are there any female children in Renaissance drama?' As the preceding chapter makes clear, female infants were present in significant numbers, but people were asking me about a particular type of female child: the pre-adolescent girl who functions predominantly as a child, who walks and talks, receives an education and participates in social relations but whose role is not predominantly sexual or romantic. By and large, the young female characters in canonical plays from the period do not correspond to the modern notion of what counts as a girl. One of my initial goals, therefore, was to figure out why that was the case. After all, plenty of young boys traversed the early modern stage. Catherine Belsey's recent study of boy apprentices in the adult companies has illuminated the importance of these roles for training boys to take on larger, more advanced female leads like Rosalind and Cleopatra. Until Belsey called attention to them, these pages had gone largely unanalysed, and she provides a wonderfully material account of the function of these 'incidental children'. She argues that they may have been receiving on-stage training to prepare them to take on older female parts. ${ }^{1}$

At first blush, it was tempting to read the scarcity of girl characters as a material constraint of the training process, but this interpretation seemed reductive and unsatisfactory. Even if the boy apprentices were not ready to play Rosalind or Cleopatra, they could have learned to play more prominent female characters while playing less prominent female children. Given the enormously resourceful imagination of the early modern theatre, surely the companies could have staged more female 
children if they had chosen to do so. Yet in comparison to boys, young girl characters seemed so much less common, especially in Shakespeare. As Mark Lawhorn points out, there is a disagreement about how many of Shakespeare's characters should be labelled children, but it seems clear that children - at least male children - 'appear frequently in Shakespeare's plays'. ${ }^{2}$ However, Lawhorn's extensive list of child characters only includes four girls: Perdita, Marina, the infant Elizabeth I and Clarence's daughter. It is possible that girls were among the children playing fairies in The Merry Wives of Windsor, but the stage directions do not specify their gender. The paucity of girls stands in stark contrast to the twenty-six children in service that Lawhorn has counted, not a single one of whom is female. Confronted with these statistics, I found myself wondering if the apparent absence of little girls in drama was evidence that Philippe Ariès was right and the early modern period did not yet have an idea of female childhood.

But that was not the case. As it turns out, girls were not absent from drama in general, but from the plays that have received the most critical attention. I simply needed to look a little harder for them. Contrary to my initial expectations, at least seventeen plays were written in which young girls appear as characters. By genre with their approximate composition and publication dates, they are as follows:

Tudor Interludes/Moralities

Nice Wanton (c. 1550; 1560)

Jacob and Esau (c. 1554; 1568)

The Comodye of Pacient and Meeke Grissill (c. 1559; 1569)

Adult Professional Plays

Richard III (c. 1592; 1597)

A Warning for Fair Women (1599)

A Larum for London (c. 1599; 1602)

The Pleasant Comodie of Patient Grissill (c. 1600; 1603)

The Valiant Welshman (c. 1612; 1615)

The Duchess of Malfi (c. 1614; 1623)

The Humorous Lieutenant $(1619 ; 1647)$

Anything for a Quiet Life (c. 1621; 1661)

The Life of the Duchess of Suffolk $(1624 ; 1631)$

The Queen and Concubine (c. 1635; 1659)

University Play

The Rival Friends (1632) 
Closet Drama

Mirza (1655)

The Hectors, or the False Challenge (1656)

\section{Masque}

John Milton, A Mask Presented at Ludlow Castle (1630)

The number of plays no longer extant makes it impossible to compile a complete list, but playwrights could and did write female children into their plays when it suited their purposes. With these plays, we have the potential to begin responding to Margaret L. King's challenge that we find alternative methods for asking and answering questions about the history of childhood, particularly those years of 'middle childhood' that remain elusive in existing historical accounts. ${ }^{3}$ I ultimately want to suggest that looking at girlhood as a strictly biological age category does not accurately reflect early modern constructions of childhood, but for the purposes of this list, I have included only plays where the female child characters are clearly coded as children. I fully recognise there is a case to be made for considering girls like Juliet as part of this group, especially since she appears with a nurse, and there is a case for including ambiguously aged female servants like Nell in George Ruggle's university play Ignoramus. I have excluded these other examples primarily to make the point that there are plenty of young girl characters to study even without the capacious definition of girlhood that I have used in my earlier chapters.

The point is that representations of female children were not all that unusual in early modern drama, even if they were not ubiquitous. To be sure, young girl characters were less common than boys, but then adult women characters were less common than adult men. By Tina Packer's count, there are seven times as many roles for men as for women in Shakespeare's corpus. ${ }^{4}$ The corresponding difference between girls and boys may well have been influenced by the limited number of boy players available in the adult companies; they would have been required to cover all the female roles as well as any children's parts. Not surprisingly, some of the most interesting examples of female child characters come from the Tudor plays that David Bevington classifies as 'children's plays at court, containing in many cases pronounced characteristics of the morality'. ${ }^{5}$ Bevington posits that the addition of boys to Elizabethan acting troupes enabled the performance of more female roles, since adult players were reluctant to take them on unless absolutely necessary for the plot. ${ }^{6}$ However, the make-up of the company's cast cannot fully explain the phenomenon, as the later children's companies did 
not feature an abundance of little girls. It was not that the Children of Paul's or the Queen's Revels could not stage female children, but that their interest in childhood focused on the virtuosity that enabled young boy actors to play a wide variety of adult roles. ${ }^{7}$ Part of the appeal of their performance was what Lucy Munro has labelled 'age transvestism', which made its meaning in the contrast between the diminutive body of the boy actor and the adult man or woman whose behaviour he imitated. Yet as Munro suggests, 'In many ways ... the differences between adult and children's companies have been exaggerated, ${ }^{8}$ and the children's companies do not seem to have been any more likely to represent female childhood than the King's Men. The fact that the later Caroline troupe known as the King's Revels included an unusually large number of boys certainly helped make it possible for Richard Brome to include 'three or four' female children in two scenes of The Queen and Concubine, ${ }^{9}$ but the extant plays performed by the similarly hybrid Beeston's Boys did not include a single female child that I have found. Simply the presence of plenty of boys in an acting troupe did not translate into representations of female childhood. To explain the presence and absence of female children in early modern plays, we have to look not only at material conditions, but also at genre and shifting constructions of childhood.

The pattern that emerges when we look at the plays featuring female children is a shift from vocal, naughty girl characters in Tudor interludes to characters that participated in the early modern cultural project of figuring girlhood as an unthreatening, innocent time of life. There were fewer prominent female child characters after the advent of the purpose-built London theatres in the 1570s, not only because the adult companies had a limited number of boys, but also because of the transition from morality-like plays to romantic comedies, histories and tragedies. When the plot focuses on the adult world rather than the individual's spiritual development, little girls tend to be static, largely symbolic presences. What I offer in this chapter is a literary history that charts the trajectory of the way early modern dramatic genres positioned female children in the context of competing understandings of gender and childhood, examining where and how little girls appeared and the kinds of cultural work they did. As Hugh Cunningham points out, 'Ideas about childhood in the past exist in plenitude; it is not so easy to find out about the lives of children. ${ }^{10}$ Fiction does not offer us an unmediated view into children's subjectivities, but representations of little girls in early modern drama can tell us about what some early modern playwrights believed female children were and ought to be. 
As explored in the preceding chapters, childhood was constructed as a crucial time for shaping moral character, and a failure to train up children in the Christian faith 'from the very cradle' could imperil their salvation. The representation of girls in Tudor interludes was filtered through this debate over original sin, and these ideological conflicts played out through the disciplining of young characters. Female children appear in three of the surviving interludes: Nice Wanton (first performed c. 1550, printed 1560), Jacob and Esau (printed in 1568 but probably performed during the reign of Edward VI), and John Phillip's The Comodye of Pacient and Meeke Grissill (c. 1559, printed 1569). ${ }^{11}$ The first two plays use female children as negative exempla for female audience members, showing the characters engaged in the unruly feminine behaviour associated with girlishness and attempting to rebuke them for it. Although not a separate kind of childhood from boyhood, girlhood in these plays is a specifically gendered experience in that it is a time when female children learn to embrace their current subordination to all adults and their future subordination as adult women to adult men. Pacient and Meeke Grissill, on the other hand, shows the supposed benefits of accurately learning those lessons, though it remains open to interpretation whether the female audience members would have found those benefits worth it when also presented with Grissill's tremendous sacrifices.

Nice Wanton tells the story of three siblings, two bad and one good, whose characters result not from natural, inborn differences but from different upbringings. In order to make the case that sinful behaviour originates in a lack of parental discipline, the play produces a kind of fictional experiment, ruling out the possibility that inherited traits cause one child to be virtuous and the others sinful. The mother Xantippe coddles and indulges her son Ismael and daughter Dalila, while harshly punishing her son Barnabas when he tries to reprove his siblings' behaviour. The prologue delivers the play's message to parents in the first few lines: 'He that spareth the rod, the child doth hate' (line 2). ${ }^{12}$ As a consequence of their mother's failure to punish them, the bad behaviour of the brother and sister pair escalates until they dramatically cast their books aside and vow never to attend school again. Led astray by the spiteful vice figure Iniquity, Ismael and Dalila fall into lives of thievery and prostitution respectively, only repenting at the end when Barnabas helps them find God's mercy.

If nothing else, this play should make us qualify the claim that girls experienced childhood less than boys because they did not attend 
school. ${ }^{13}$ These are fairly young children of the wealthier middling class who appear to be attending primary school together. Like the conduct manuals that I discussed in Chapter 2, the goal of their education seems to be instilling a sense of moral rectitude rather than learning for its own sake, and Dalila takes her lessons along with her brothers. The first rebuke that Barnabas utters directly to his siblings calls attention to the fact that proper behaviour was expected of children of both sexes, but that those rules applied in a particular way to girls. When Dalila and Ismael enter singing a snatch from a ballad, Barnabas scolds them, 'Fie, brother, fie, and specially you, sister Dalila! Soberness becometh maids always' (lines 41-2). His statement indicates that children of both genders were expected to repress their natural exuberance, but that not to do so is particularly unbecoming to maids. In essence, Dalila's behaviour is particularly childlike, and her refusal to conform and discipline herself locates her in a realm of girlhood, rather than sober maidenhood. Instead of listening, however, Dalila confirms her girlishness, retorting, 'What, ye dolt, ye be ever in one song' (line 43). Dalila has heard this lecture before, and she is not having it. She, along with her brother Ismael, reject their brother's suggestion that she should 'learn apace ... and after to spin and sew / And other honest huswifely points' (lines 49-50). Ismael, who dislikes this idea as much as his sister, retaliates on her behalf. He trips Barnabas, who goes off to school in a huff. Resolving never to go to school again, the naughty siblings determine to avoid the churlish beatings of their master and the uncomfortable temperatures of the schoolroom by going off to play instead.

The play figures childhood (not surprisingly) as a dangerous time, when children can be fashioned like a ball of wax into upright, obedient subjects or, if left to their natural inclinations, grow crooked like unruly plants. Where the older Ismael and Dalila are 'brought up wantonly in play' with their mother excusing their dalliance and mischief (line 13), she treats Barnabas more strictly, punishing him when he tries to check his brother and sister's behaviour. As such, Barnabas becomes a strange test case of the 'good' child, whose future as a 'good' adult is predicated on his childhood treatment, even as that treatment seems to depend upon his natural proclivities to follow the (masculine) advice of his schoolmaster, rather than indulging his mother's desire to coddle his siblings and allow them a space of freedom and play in their youths. Barnabas figures as an embodiment of moral rectitude who ineffectively attempts to curb his brother and sister's sinful tendencies, like one of the virtues in a morality play. The play begins with Barnabas expressing anxiety that his schoolmaster will beat him because his slothful brother and sister have made him late for school, and throughout the play he 
repeats the lessons of his schoolmaster. When he lectures his mother, he emphasises not sparing the rod, and when he addresses the audience, he focuses on the lesson of Ecclesiastes that 'Man is prone to evil from his youth' (line 27).

And Barnabas's predictions invariably come true in ways that suggest that the sins of youth may not be gendered, but boys and girls pay a gendered price for engaging in them. Truancy leads Ismael and Dalila into the company of Iniquity, a spiteful allegorical vice figure who teaches them to gamble, encourages them to swear and becomes Dalila's lover. Although the siblings share the same initial misdeeds, Dalila's fate takes on a gendered narrative - she becomes a whore and dies of syphilis, whereas her brother gets hanged for being a thief. Their initial forms of rebellion do not differ; both children sing songs, refuse to go to school, gamble and engage in sex. It is not the sins that are gender specific, but the punishments. From a modern perspective, what is most disturbing about the play's condemnation of Dalila is that it takes what we define as statutory rape and makes her culpable for the actions of an adult. The play asks us to condemn not only the mother for failing to raise her children correctly, but also the child for being corrupt. This is a very different approach to childhood subjectivity than our own; it neither grants the child individual agency to determine herself, nor sees her therefore as unable to be held accountable for her actions. There is no sympathy for the children of neglectful parents.

As a contemporary reader, however, it is hard not to experience a little vicarious pleasure when Dalila calls her brother out on his sexual double standards. The siblings eventually turn on each other while playing dice. When he teases her that her maidenhead 'is sick', she retorts that he 'hath whores two or three' and threatens to tell his 'minion doll' about them (lines 153, 156-7). Her verbal acuity is strong enough that she reduces Ismael to calling her a 'whore' and threatening to give her a box on the ear. Having initiated the disagreement by egging the two on, Iniquity calms them and convinces them to keep playing at dice, with Dalila playing on Iniquity's team. Together they sing a bawdy song in which Dalila matches Iniquity's innuendo point by point. Iniquity sings about the need to give his golden-haired mistress the 'knocks', so Dalila counters by suggesting that the male lover had best take his time in bed because 'the winter nights be long' (lines 196, 200). When Iniquity responds by saying that he would 'take it for no wrong' if he needed to try 'another assay', Dalila does not miss a beat: 'Then, by the rood, / A bone in your hood / I shall put ere it be long' (lines 202-206). Having seen his sister express her sexual desires in language just as witty (and vulgar) as Iniquity, Ismael declares to Iniquity, 'She matcheth you, 
sirrah!' (line 207). On the one hand, he and Iniquity have a certain amount of admiration for Dalila; on the other, they clearly think less of her for behaving like them. Iniquity responds with 'knavish' praise, declaring her 'the best whore in England' (line 208). Engaging in masculine culture literally leads Dalila to become a whore; the epithet is more than a metaphor.

The more elaborate biblical drama of Jacob and Esau takes a strikingly different approach to the relationship between children and original sin, even as it upholds the same social and religious values. The central message of the play, expressed in a song performed by the serving girl Abra, is the aphorism 'Yong doth it pricke that wyll be a thorne'. ${ }^{14}$ Bad children grow up to be bad adults. The central illustration of this proverb comes from the brothers Jacob and Esau, where Esau's ill temper in his youth becomes a sign of his innate corruption. The pedagogical purpose of the play is to show the impossibility of subverting God's will, but it's difficult to know exactly what kind of lesson the audience is supposed to take away. The play ostensibly speaks against the possibility that human action can change God's will, but the will of God becomes the justification for Rebecca taking a good deal of action to overturn Esau's status as her husband's heir. The ordering of the social hierarchy based upon a natural birth order gets reconfigured so that the natural order comes to be contingent upon the will of God. In Rebecca's words, 'God hath appointed [Jacob] / As the eldest sonne unto Isaac to bee' $(2.4$, sig. D2r). That is, the 'elected' takes the place of the naturally born, thus making Jacob (the youngest son) the older son in terms of inheritance rights. ${ }^{15}$

These questions about birth order get mapped on to the relationship between the child servants, Abra and Mido. We know that the little girl Abra was supposed to be relatively young from the title page's list of players, which identifies her as 'a little wench, serua[n]t to Rebecca'. Her littleness pairs her with Mido, 'the little Boy, leading Isaac'. As the play's two children, they provide a counterpoint to the adult parents, Isaac, whom the title page labels 'an olde man', and Rebecca, 'an olde woman[n]'. Jacob and Esau occupy the middle ground between the old parents and the little children, being listed as 'young' men, the former a man 'of godly conuersation' and the latter 'a hunter'. The parallels between the two pairs of children - Jacob and Esau and Mido and Abra - suggest that just as Jacob overturns the natural birth order to rule over Esau, Mido will eventually rule over the slightly older Abra because, according to God's will, gender trumps age in the adult social order.

As such, the two children comment both on the marriage of Rebecca and Isaac and on the sibling relationship of Jacob and Esau, and they 
do so in ways that paradoxically reinforce the central message of the play. Mido and Abra reiterate the questions raised by the relationship between Jacob and Esau but with a difference. Rather than who is more worthy to rule, the elder or the more godly, the question is, who is more worthy to rule, the younger boy or the older girl? Mido, who serves as Isaac's eyes, offers a child's-eye view that sees without understanding the causes of how the adult world works. He observes that Isaac loves Jacob more than Esau and does not know the cause: 'And none other cause know I. / But euery body as well one as other, Doe wish that Jacob had bene the elder brother' $(1.4$, sig. B4v). He speaks the truth and sees the world for what it is in a way the blind Isaac cannot. When Rebecca insists on leading Isaac, her husband wishes that all wives '[w]ould vnto their husbandes likewise do their office' $(1.4$, sig. B4v). In a witty rejoinder, Mido turns this call for wives to do their duty on its head, betraying an awareness of the fact that Rebecca really does lead Isaac; he points out that if all wives led their husbands the way Rebecca does, 'then al wedded men shold be blind' (1.4, sig. B4v).

Rebecca's comment that God has appointed Jacob to be Esau's elder brother rhetorically positions God's will as unmaking history and remaking the natural order, and it is followed closely by an exchange between Abra and Mido in which they spar about who has more authority. Abra, true to her saucy nature, does not accept Mido's claim that being male gives him precedence. Rebecca issues an order to 'Abra, and little Mido', and Mido bristles, 'Nay ye should haue set Mido before Abra, trow. I For I am a man toward, and so is not she' $(2.4$, sig. D2r). Mido's insistence that his name should come first, as Jacob's does in the interlude's title, shows his awareness of his future gender privilege. He may not yet be a man, but he is 'a man toward', and he is wasting no time in claiming his place above his female counterpart. Abra in response counters his claim by pointing out, 'No but yet I am more woman toward than ye' $(2.4$, sig. D2r), a funny statement, since Mido is never going to be a woman. Her point, of course, is that she is older than him, an argument that picks up on the tensions that result from intersecting forms of social hierarchy in early modern England; young boys might have had gender privilege, but they could still be subordinate to women because of their age and class status.

The disagreements between Abra and Mido serve to highlight the difficulty of policing patriarchal relations in the face of other forms of hierarchy. They are struggling with the 'interlocking structures of domination' that Elisabeth Schüssler Fiorenza has called kyriarchal relations. ${ }^{16}$ When Rebecca asks the two children not to speak a word of her plan to deceive Isaac, Abra promises, 'For my parte it shall to no 
body uttered be' (2.4, sig. D2r) and Mido, still harping on gender stereotypes, replies, 'And slit my tongue, if euer it come out for me: / But if any tell, Abra her, will be prattling. / For they say, women will euer be clattering' (2.4, sig. D2r). Mido here is repeating a lesson on women that he has learned earlier in the play from Isaac. When Mido comments on the fact that Rebecca has been holding her own in a debate between husband and wife about the merits of their two sons, Isaac replies, 'Yea, womens answeres are but fewe times to seeke' (1.4, sig. B4v). Having learned from his master how to belittle women for speaking, Mido uses a typical misogynist tactic to manoeuvre Abra into an impossible position, where responding only confirms his accusation of verbosity. She does the best she can by pointing out that Mido himself likes to talk. 'There is none here that pratleth so much as you,' she retorts $(2.4$, sig. D2r). The exchange echoes an earlier one between Rebecca and Isaac, thus producing a complex and confused matrix of authority; Mido has invoked gender while Abra appeals to age and social status, with Abra getting the last word. This general sense of contradiction extends to the play's overall message, where Rebecca serves her husband by deceiving him, calling into question how much power an earthly patriarch truly has.

I do not mean to suggest that Abra is not a saucy servant, but the play presents her wittiness as both charming and wilful. Even in the above exchange with Mido, Abra comes across as bold and assertive, making her both appealing and potentially dangerous. Like Mido, her attractiveness to the audience lies in her comic take on the adult world. Both children point out the inherent injustices of the social order, as well as its contradictions. If Abra's position as a young child links her with Mido, her identification on the title page as 'servant' also links her to the other character identified as a servant - Ragau, Esau's beleaguered and vociferously complaining attendant. Together they offer complementary critiques of a social system where servants must follow masters, regardless of the master's behaviour or the impossibility of fulfilling the master's demands. Ragau's complaints about the ill treatment he receives from Esau go hand in hand with the justification for the older brother's disinheritance; Esau abuses his servant physically, starves him and makes impossible requests. As a bad master, he does not deserve to be Isaac's heir, and his antisocial behaviour within the larger social community serves as a sign of reprobation.

Abra's behaviour indicates that she has internalised her position in the social order, but she still poses a potential problem because her relationship with Rebecca is clearly fraught. Abra wishes to please her, but still looks to undercut and mock the impossibility of always doing as she's 
told immediately and perfectly. When Rebecca calls for Abra in Act 4, Scene 3, Abra responds from inside the family's tent that she is within. Irritated, Rebeca commands her, 'Come forth: When? Abra, what Abra I say.' Like Juliet on the balcony putting off the Nurse, Abra calls 'Anone' from inside. Rebecca calls a third time, 'Must I call so oft? Why come ye not by and by?' When Abra emerges from the tent, she points out the inherent contradiction between fulfilling competing duties at the same time. She has been washing her 'vessel', and putting it off would make her disobedient. Instead of recognising the impossibility of Abra both washing her vessel and responding immediately, Rebecca simply reaffirms her standing order that Abra 'looketh all your vessells be clene' (4.3, sig. E1v-E2r).

But whereas Mido's and Ragau's critiques register as social commentary, Abra's code her as a future shrew. The nurse Deborah describes her as a female version of Esau whose inherent nature will lead her to grow up from being a naughty girl to a shrewish woman:

There is not a pretier gyrle within this mile,

Than this Abra will be within this litle while.

As true as any stele: ye may trust her with gold.

Though it were a bushell, and not a peny tolde.

As quicke about her worke that must be quickly spead

As any wenche in twenty mile about her head.

As fine a péece it is as I knowe but a few,

Yet perchaunce her husbande of her maye haue a shrewe.

Cat after kinde (saith the prouerbe) swete milke wil lap,

If the mother be a shrew, the daughter can not scape.

Once our marke she hath, I maruell if she slippe:

For hir nose is growing aboue hir ouer lippe.

But it is time that I into the tent be gone.

Lest she come and chide me, she will come now anone.

(4.4, sig. E3r)

Although the nurse sees Abra as trustworthy and praises the quickness with which she does her work, Deborah nonetheless insists that because Abra's mother was a shrew, Abra cannot escape the same fate. This sense that one's personality is inborn and cannot be changed runs counter to the nurse and Rebecca's pedagogical attempts to teach Abra obedience, and indeed it runs counter to all of the conduct manuals examined in Chapter 2 that assume that female infants are malleable and can be made into suitably submissive women.

The little girl Abra strangely embodies while simultaneously ventriloquising the play's message that those who are bad as children will grow up to be bad as adults. While finishing her cleaning like a good girl, Abra sings a song about the inflexibility of people's characters: 
He that were now within, should find all thing I wene,

As trimme as a tre[n]cher, as tricke, as sivete, as cleane.

And seeing that my dame prepareth such a feast,

I will not I trow be found such a sluttishe beast,

That there shall any filthe about our tent be kepte,

But that both within and without it shall bee swepte.

(4.4, sig. E2r-E2v)

Abra then sings the song that voices the interlude's moral theme, 'Yong doth it pricke that wyll be a thorne', a proverb that not only comments on the main story but also puts in Abra's own mouth the words that Deborah uses to forecast the impossibility of making Abra into an appropriately subservient woman. According to the song, those who are prone to evil in childhood will most likely be evil in adulthood. It does not say that children who are 'slack to worke' in childhood will definitely be thorns, but the song does present it as a 'Great meruaile... if such come to grace'. Slackness is precisely the defect of which Abra is repeatedly accused, and thus the song provides a particular comment on her nature. It allows for education to change a child's underlying nature, but the play's overall message contradicts it, as when the neighbour Hanan employs the same proverb to call attention to Esau's reprobate nature:

But Esau euermore from yis yong childehoode Hath ben lyke to prue yll, and neuer to be good.

Yong it pricketh (folks do say) that wyll be a thorne,

Esau htath ben nought euer since he was borne.

And wherof commeth this, of Education?

Nay it is of his owne yll inclination.

They were brought up bothe under one tuition,

But they be not both of one disposition.

The experiment of Jacob and Esau's equal upbringing and its result demonstrates that children's characters are fixed from birth. Abra's potential to become a good girl and Esau's destined wickedness from birth undermine each other. In the end, Esau's 'conversion' via his divestment of his inheritance has its parallel in the idea of subjection, suggesting that perhaps Abra's ability to avoid becoming a thorn lies in subjection to a husband.

Abra's problem, however, is that truly submitting, truly pleasing all of her potential masters, does not seem to be possible. Having finished her song and her sweeping, her childlike desire to go and play cuts in on her duties. She notes that if it weren't for the need to perform extra labour in the service of cooking the goat for Rebecca's trick on Isaac, 
she would be free to play: 'Now but for setting mine herbes I might go play' $(4.4$, sig. E2v). By expressing a desire to play, Abra reveals not that she is slack in her duties, but that she would like to be; she works through compulsion rather than a natural desire to be industrious. And if that were not enough, her next act calls attention to the difficulty of performing multiple tasks at once. She calls in Deborah for assistance because Rebecca has charged her with keeping the cooking fire burning and collecting herbs, two tasks that one person cannot perform at once. Despite going out to get the herbs and going as fast as she 'can trotte', she does not receive praise for being a good servant; instead, the play has her deliver a condemnation of any other servants who do not perform their duties properly:

A straw for that wenche that doth not somewhat likely,

I haue brought here good herbes, \& of them plenty

To make both broth and farcing, and that full deinty

I trust to make such broth, that when all things are in,

God almight self may wet his finger therein

But to tary here thus long, I am much to blame.

For, if Jacob should come, I not in readiness:

I must of couenaunt be shent of our maistresse.

And I would not for twenty pounde I tell ye,

That any pointe of default should be found in me.

(4.5, sig. E3r)

Abra has learned to compare herself with other women, and she has internalised the exhortations of her superiors who tell her not to tarry or be slack. She wants to be a good servant, and she takes pride in having done a good job collecting herbs, providing a detailed catalogue of all she has collected for the audience. Ironically, her attempts to prove her worth lead her to tarry for too long and to blame herself for not discharging her duties quickly enough.

Has she then been brought into line with her proper feminine role despite her slack nature? Not quite. Abra's last appearance in the play is when Esau comes to Jacob's tent and threatens to kill Esau, Ragau, Abra, Mido and Deborah. She exits the stage by taking a final parting shot at Esau, which suggests that she has not entirely given up her vocal nature and that her inculcation into obedience may not be so complete. Esau's abusive language gets expressed through stichomythia in an exchange in which he links Abra to demonic behaviour and sluttishness. 'Come out thou little fende, come out thou skittish Gill,' Esau orders, to which Abra laments, 'Out alas, alas, Esau will vs all kill' (5.6, sig. G1r). By calling the little girl a fiend, Esau suggests that Abra is not only 
unsaved, and thus not part of the elect, but also works for the devil. In the latter part, the phrase 'skittish Gill' marks her as excessively lively and frivolous (Oxford English Dictionary a.1), and 'gill' was a familiar, in many cases disrespectful term when applied to young women, a derivation from the common name Gillian (OED n.4). It was also a small vessel used for measuring liquids, roughly one quarter of a pint or a half-pint in some locations (OED n.3). Esau's particular choice of word harks back to Rebecca's admonition that Abra should always keep her vessel clean.

Esau proceeds to interrogate each of the servants individually, at one point threatening to whip Abra. Abra asks for Ragau to speak on her behalf, and he complies, insisting she has 'done none euill'. This intervention proves ineffective with Esau, who continues to insist on her inherently evil nature: 'A little fiende it is, and will be a right deuill, / And she is one of them that loue not me a deale' (5.6, sig. G1r). If Abra has been taught the necessity of deferring to men, she learns that she is her own best advocate; she turns to equivocation and uses her linguistic skills to get herself off the hook. She declares, 'If ye let me go, I will loue you very wele' (5.6, sig. G1r). The conditional 'if' and the promise of future love secure her freedom from harm, but unlike Mido, who flees as soon as Esau gives him leave, Abra breaks her promise. She leaves the stage with a final piece of swagger. Her last words in the play are, 'Adew, I set not a strawe by you nor a pinne' (5.6, sig. G1r). Girlhood in this play is a time of service and subordination, but it is also a state of mind that resists that subordination; it is a stage to be passed through, but one that also can never quite be shuffled off.

II

In contrast to naughty Dalila and saucy Abra, Griselda functions as an example of the obedient woman on whose behaviour young girls and future wives were told to pattern their behaviour. She is what happens when a female child successfully becomes a chaste, silent and obedient woman. Her story, told over and over again in the period, goes as follows: a rich Marquis falls in love with a poor but beautiful woman; he marries her and decides to test her fidelity. When she gives birth to two children (a daughter and then later a son), he claims that his subjects will not accept them as heirs because of their mother's low birth. $\mathrm{He}$ orders them to be killed, and instead of fighting for her children or objecting to her husband's tyrannous behaviour, Griselda meekly and patiently submits to his wishes. Some period of time later (twelve years 
in Giovanni Boccaccio's Decameron and Petrarch's Latin translation of Boccaccio), the Marquis claims to be divorcing his wife and requires her to help prepare his new, young bride for the wedding. Griselda agrees, and the Marquis reveals that he never had the children killed and that the new 'bride' is actually their daughter. ${ }^{17}$

We have two early modern dramatic versions of the Griselda story, John Phillip's interlude The Comodye of Pacient and Meeke Grissill and the later turn-of-the-century The Pleasant Comodie of Patient Grissill by Henry Chettle, William Haughton and Thomas Dekker. As Pamela Allen Brown has shown, 'By the late sixteenth century, the plays of the saints had been banned, but the sufferings of secular martyrs such as Lucrece and Griselda had replaced them as moral spectacles. ${ }^{18}$ Brown provides a rich history of the evolution of the Griselda myth from its folkloric roots in medieval Smyrna through the tales of Boccaccio and Petrarch in fourteenth-century Italy into English with Chaucer's 'Clerk's Tale' in the early fifteenth century. As she points out, some authors retold the fable earnestly as a lesson in wifely obedience, but it was always controversial, the figure of Griselda eliciting disbelief and ridicule because her obedience oversteps the bounds of reason. For every story praising her in earnest, Brown finds fissures and cracks in the tale's reception that suggest a healthy scepticism about Griselda's usefulness as a model, particularly coming from the Nurse in Phillip's version and the shrewish character Gwenthian in Chettle, Haughton and Dekker's. As is so often the case with tales of idealised femininity, it is not clear that conforming is worth the supposed rewards.

At the centre of the tensions over Griselda's behaviour is her attitude toward her children, whom she willingly sacrifices to her husband's tyrannical whims. As in Brown's astute analysis, much of the scholarship on the Griselda tale focuses on what her sacrifice says about wifely obedience and motherly behaviour. ${ }^{19}$ I want to shift the interpretive lens slightly to look at what the play's use of the son and daughter suggests about the role of female children and childhood in drama. Phillip's play, much more so than Nice Wanton and Jacob and Esau, anticipates the general use of little girls on stage in the professional companies, a trend in which Chettle, Haughton and Dekker participate. In these plays, the successful inculcation of the Griselda figure's adult femininity correlates to a flattened and stabilised portrayal of female childhood.

Phillip's version presents the title character named Grissill first as a dutiful daughter before she becomes a dutiful wife. Like a female Barnabas from Nice Wanton, she demonstrates her virtues through repeating maxims about the appropriate behaviour of children, singing a musical version of a conduct manual while she spins: 
Let Children to their parents giue

Obedience Due, as they are taught,

Then they on earth full long shall liue

$\&$ ioy ye place which Christ hath bought

With his hert blood, \& Deadly wound,

Whear lasting ioyes shall aye abound,

Singe danderlie Distaffe, \& danderlie,

Let children all come learne of mee.

$(\text { lines } 227-34)^{20}$

Grissill's song offers a meta-comment about the lesson that the audience - imagined as children - should take from her actions. In her modesty, she embodies the kind of obedience little girls and boys were expected to show to their parents, and at the beginning of the play, she is first and foremost a good daughter to Jannickle. Her personality as a child leads directly to her personality as a wife.

In contrast, we do not directly see her daughter's education in feminine obedience, as she and her brother grow up off stage. The daughter, like her brother, functions not as a character in her own right, but as a pawn in adult power negotiations. She appears on stage as an infant and only returns at the end. Her role in the denouement, however, is more prominent than her brother's because of her substitution for her mother in the mock marriage ceremony. Her age is unclear, although she seems to be somewhere in her early adolescence, and both Petrarch and Boccaccio explicitly state that twelve years have passed. When the Marquis brings the daughter in, she speaks like a second incarnation of her mother, casting herself as her father/husband's subservient mate: 'And eke to thee as dutie byndes, loues fruites I will imparte, / Thou onlye my beloued mate, inioyest thy seruants harte' (lines 1883-4). These words conflate service and marriage, blurring the lines between economic and affective relationships in ways that sound hauntingly like Grissill's earlier in the play when she registers discomfort over her economic inequality with the Marquis. The daughter effectively conflates gender and social distinctions such that her father/husband becomes her master. ${ }^{21}$ It is as if the temporary substitution of the Marquis's high-born daughter who has been raised as an aristocrat elevates her mother's social position and wipes out the initial concerns over their class differences.

The role of the daughter in the play is largely to reproduce her mother's passive, obedient femininity. After her mother's and her own identity are revealed, the daughter spins Grissill's trials as having been suffered for her, and she vows to repay her with 'Childlie obedience': 'Ah my sweet mother, did thou suffer such payne, / For me thy Childe, 
great is thy pacience / God graunt I maye kindly, reweard thee agayne, / With the perfecte fruictes of Childlie obedience' (lines 1959-62). In the context of the play, where her mother's actions have been explicitly for her husband rather than her children, the daughter's response seems out of place until we consider her mother as a teaching tool for girls, the children to whom she sings her song.

The later comedy by Henry Chettle, William Haughton and Thomas Dekker has traditionally been read as more complicated in its representation of class and more political in its critique of the court. The Marquesse (called Gwalter in this version) tests Grissill not because he's been led astray by vice characters, but because he needs to prove Grissill's worth to his courtiers, who would not otherwise accept her as his legitimate wife. Like Perdita in The Winter's Tale, Grissill demonstrates her worthiness by being a poor woman who respects class differences:

Oh, my gracious lord,

Humble not your high state to my low birth,

Who am not worthy to be held your slave,

Much less your wife. ${ }^{22}$

Unlike Perdita, she is not secretly royal; she is genuinely the daughter of a basketmaker. The play paradoxically holds out the promise of elevated status as the reward for refusing to pursue it. Grissill's brutal mental and physical trials come to be the price she pays for moving up in the social hierarchy, a kind of feminine proxy for class.

This version, like Phillip's, uses the daughter primarily as a conduit for Gwalter's mistreatment of Grissill and as a means for reuniting them. Like her earlier self, Gratiana the Marquesse's daughter reappears at the end in a mock wedding ceremony where her mother graciously welcomes her and blesses her anticipated union. Grissill explicitly calls attention to the girl's 'tender' years, asking that her ex-husband deal more softly with his new bride. By acting as a tyrannical, abusive husband, the Marquesse gives Grissill the opportunity to impress the members of his court with her patience and obedience, which works to cancel out her class status. By substituting the daughter for the mother, however momentarily, the ceremony naturalises Grissill's upper-class status, using her daughter's experience of being born into the aristocracy as a way of suggesting that her mother's class markers come through her progeny. The aristocratic daughter gives birth to the aristocratic mother.

Unlike in the earlier play, however, neither child in this version speaks. One of the central differences between the daughters is that Phillip's boy 
actress would have had to be fairly experienced. The title page doubles her role with several of the major allegorical figures, including Reason, Diligence and Pacience, as well as the Countess's maid. The same is true for her brother, who doubles with Fidence, Indigence and the Second Page. In contrast, Chettle, Haughton and Dekker employ a more extensive cast, and while the children may have doubled with some of the other minor characters, they could not have doubled with any of the major cast members, most of whom are present with them in the final scene. As a result, the children appear on the stage largely as sentimental objects, as props to facilitate the reconciliation of their parents and to invoke the pathos of reunion. This instrumental and sentimental function was one of the most common reasons that later playwrights would incorporate female children into their storylines. Girls appear, but the plays do not focus on their maturation process. It is far more common for girls on the stage to fulfil symbolic roles, like Clarence's daughter in Richard III, who along with her brother helps amplify the play's depiction of Richard as a villain through his mistreatment of children. Likewise the unnamed older sister of Young Sanders in A Warning for Fair Women remains silent, but she appears at the end of the play as a catalyst for her mother's conversion and repentance. The result is that these plays place much less emphasis on female children as disorderly miscreants and much more emphasis on the cultural aesthetic that valued girls as symbols of innocence.

The most striking example of a girl character participating in the sentimentalisation of girlhood comes from the anonymous 1602 play $A$ Larum for London, which dramatised the sack of Antwerp as a warning to London of what would happen if its residents continued to be decadent and materialistic. The role of little girls in creating pathos was part of a general construction of childhood as a time of vulnerability, but it could have a distinctly gendered charge. ${ }^{23}$ The Spanish, especially their commander Danila, engage in a series of over-the-top violent acts, chanting 'Kill, kill, kill' (line 1127) before slaughtering two little children, a young girl named Lenchy and the little boy named Martin. ${ }^{24}$ They appear together as a brother-sister pair, entering the stage running and then begging for their lives. Martin pleads, 'We are poore children, we haue done no harme' (line 1132), exhibiting an awareness of his own childish state of innocence. His sister selflessly chimes in to defend him, asking, 'Good Gaffer doe not kill my little brother' (line 1133), to which Martin adds, 'Ah Master Spaniard doe not kill my Sister / My father is a poore blinde man, and he will dye, / If you kill her' (lines 1135-6). Despite the pitiful pleas of the brother-sister pair, the hardhearted Spaniards remain steadfastly committed to slaughter, prompting 
Lenchy to try to use her identity as a specifically female child to sway her attackers:

O kill vs not, wee'll hang vpon your armes, Sweet Gaffer, stay and looke me in the face, Haue you the heart to kill a prettie Girle?

(lines 1140-2)

In contrast to Lenchy's invocation of her prettiness and status as a girl, Martin attempts to appeal to the soldiers' mercenary inclinations, offering 'any thing' they have in exchange for sparing their lives. Neither approach works, and the soldiers slay them.

Even when not being so explicitly linked to physical violence, the dependence of children on the goodwill of the adults around them was often clear in the plays in which they appeared, as in Thomas Middleton and John Webster's city comedy Anything for a Quiet Life (1621). Maria and Edward Cressingham are given over to the care of the mercer Water Chamlet in the wake of their father's marriage to a new wife, and they function principally as plot devices to sow discord between Chamlet and his wife Rachel, who mistakenly believes them to be her husband's bastard children. When Maria overhears Rachel Chamlet call her and her brother bastards, Maria asks her guardian if she heard her correctly, and he denies it, claiming the remarks were aimed at Cressingham's older sons (who are disguised as tailors in the scene). Maria's response plays up her innocence and goodness, as she offers to leave so as not to upset his wife: 'Truly Sir, I would not, for more treasure than ever I saw yet, be in your house a cause of discord' (4.3, sig. C3v). Rachel Chamlet abandons the house to stay at her cousin's until the children are removed, and they are accordingly sent back to their father, Sir Francis Cressingham. Sir Francis has been facing pressure from his new wife to sell his lands and buy new ones in Ireland, but he is so moved by the sight of the children that he resolves not to do it because it would endanger their future. In the end, Lady Cressingham turns out to have been testing her husband, and her kindness to the children in Act 4, Scene 3 is one sign of her secret goodness. The children come back on stage later with her during her reconciliation with her husband, but they otherwise do not speak. The children's brief dialogue seems like a good training set piece for boy actors learning the business, as it relies predominantly on the responses of the adults around them. Minor parts for girls, as well as boys, were clearly in use. What changes from the Tudor interludes to these later public stage plays is that those minor parts for boys playing girls tend to dramatise girlhood (and childhood more generally) as a distinct way of experiencing powerlessness within the adult world. 
Thus far I have been focused on girls who appear vulnerable because of their youth, but their identities as children depended as much upon their social subordination. Female childhood in these plays, like childhood more generally, gets determined by both age and social status. The interlocking connections between youth, service and power expose the limitations of examining girlhood exclusively as a biological category. As a result, my list at the beginning of this chapter is necessarily contingent upon a shifting set of criteria for defining girlhood. As the Nurse in Christopher Marlowe's Dido Queen of Carthage (1594) points out, eighty can be a girl's age if a woman lives to be a hundred: 'I may live a hundred yeares: / Fourescore is but a girl's age (4.5.31-2). More pressingly, a strict demarcation between female children and female servants is not historically accurate. Childhood as a concept, even when closely tied to age, is almost always relational and class specific. It is clear that girls from the middling class like Dalila in Nice Wanton belong on my list of early modern child characters because they attend school; Nell, the female servant in George Ruggle's Latin university play Ignoramus (1615), probably also belongs on that list, but I have left her off, since her age remains ambiguous..$^{25}$ This distinction is an artificial one that was not upheld in the drama itself. Labelled ancilla (maid servant) on the cast list rather than puella, Nell is nonetheless paired with the pageboy Vince, labelled puer. Act 5 features a verbal sparring match between the two of them after they have accompanied their mistress Dorothea to Bordeaux. Part of what marks them as different from the people they serve is that they speak in English rather than Latin, a sign of their lesser educational backgrounds. Vince's use of bawdy innuendo during Nell's very brief Latin lesson resembles young Will in The Merry Wives of Windsor, making Nell an interesting conflation of Mistress Quickly and a childish pupil. She ends up playing her fellow servant's fool, accidentally making a sexual pun when Vince convinces her to answer 'horse's tool' when her mistress asks the meaning of $\operatorname{brachium}\left(5.1\right.$, sig. G7v). ${ }^{26}$ At the beginning of the next act, Vince continues to tease her, asking if she has ever seen the man in the moon, and when she looks up, he uses the opportunity to chuck her under the chin. His playfulness and her subordinate power relationship to her mistress puts her on a continuum with girl servants like Abra in Jacob and Esau and marriageable servants like Nerissa in The Merchant of Venice. As a maid, she does not have full adult privileges, and yet she is not precisely a child, which she calls attention to when she comments that it is strange being in a country where the 'barnes' speak better 'French' than she does (5.2, sig. G8r). 
Characters like Nell confound artificial attempts like mine earlier to draw neat parameters around the category of the female child.

In general, the relatively early entrance into service for women of all classes can be seen as either extending the period of female youth or cutting it short. On the one hand, apprenticeship would have lengthened the time between childhood and the assumption of full adult responsibilities and privileges. On the other, it cuts working girls off from the middle-class idea of childhood as a place of freedom and play. Ilana Krausman Ben-Amos argues that despite the limitations on women's opportunities for work, the teens and early twenties were the time that afforded non-aristocratic women the highest level of mobility and personal autonomy available during the period. Through a variety of apprenticeships, women had 'considerable scope for independence and initiative during their adolescent and youthful years' ${ }^{27}$ Ben-Amos is slightly less optimistic than K. D. M. Snell about the extent to which girls participated in apprenticeships because she claims the variety available to girls were not as wide ranging as those available to boys and that many of them were principally apprenticeships in huswifery. ${ }^{28}$ Nonetheless, it is clear that young girls and women of a variety of classes went out to work in other households, and it was seen as much a part of female youth as formal education.

The representations of female childhood as intertwined with service makes it difficult to examine it as separate from class status. This is especially true because some of the plays feature scenarios in which young girls are sexually exploited because of their poverty. The girl Phoebe in John Fletcher's The Humorous Lieutenant (c. 1619) appears briefly as a victim of what looks remarkably like an early modern version of sex trafficking. The activities of Leucippe, a courtier's wife and bawd, participate in the play's larger social critique of licentiousness at court as she procures country girls and urban widows who are willing to sell their services to aristocratic men in exchange for a temporary income - that it is temporary is clear from Leucippe's rejection of a widow whom she deems too 'musty' to be 'man's meat' (2.3.36-7). Set in the Middle East just after the death of Alexander the Great, the plot revolves around the military conflict between King Antigonus and the other Greek leaders among whom Alexander's kingdom was split. ${ }^{29}$ The romance between Antigonus's son Demetrius and the unknown 'foreigner' Celia eventually serves to reconcile the feuding kingdoms when Celia turns out to be the daughter of Seleucus, the leader of the opposing forces. Along the way, however, the king's lechery threatens the young people's relationship when Antigonus asks Leucippe to try to procure Celia's sexual services. The court's corruption emanates from the bawd's services, including the 
imbalanced humours of the title lieutenant, whose unspecified illnesses are implied to be the result of consorting with whores like the ones that Leucippe procures for the other courtiers. Thus the political concerns of the play become entangled in domestic concerns about continence and moral behaviour.

Yet the brothel itself resembles a regular merchant's business more than a sensual den of pleasure. Two characters labelled 'Maid 1' and 'Maid 2' keep records, look through papers and report on potential prostitutes, including the fifteen-year-old daughter of a country gentleman. As with her other potential goods, Leucippe describes the girl as merchandise, estimating that the girl's virginity is probably worth three hundred or more crowns, enough to buy the girl's father a new hunting nag (2.3.22). Indeed, the early modern stage seems to have imagined female children and young women as peopling the space of brothels both in London and abroad. In one farcical episode of Thomas Heywood's If You Know Not Me, You Know Nobody, Part Two (c. 1606), the haberdasher Hobson chases his wayward apprentice John Gresham (Thomas Gresham's nephew) to a whorehouse in France. When Hobson, clad in his slippers and nightgown, knocks on the brothel door, a young woman who is labelled Puella in the stage directions greets him. The reversion to Latin (she is called Wench in the speech prefixes) implies a certain illicit nature to her position, although her age, like Nell's in Ignoramus, remains ambiguous. Hobson calls her 'girle', 'wench' and 'damsel', an indication of his inability to pin down her social position.

By emphasising the connection between reaping high profits and looking like a member of the upper classes, Leucippe's rhetoric in The Humorous Lieutenant attempts to obscure her exploitation of the very real poverty of other women. The play exposes her business as exploitative by bringing on the 'tender girl' Phoebe, whom Leucippe buys from her mother for ten crowns. The child's age is unspecified, but the adjective 'tender' suggests that she is younger than the other maids and closer to childhood than maidenhood. Phoebe speaks only one line (telling her name) before being taken off stage to be redressed in attire appropriate for her new apprenticeship. As a role, Phoebe seems an excellent training position for a boy apprenticed to learn female parts, so she may well have been largely intended to help build the skills of the boy playing her. Within the framework of the plot, she offers a comment on the vulgarity of those like Leucippe who would take advantage of economic necessity to coerce female children into prostitution. As such, Phoebe functions first and foremost as an example of the way little girls might circulate as property in the early modern economy, put out for service not for their own training but for the economic benefit of others. Much 
like the 'whore plays' set in London that Jean E. Howard has studied, The Humorous Lieutenant negotiates 'the changing place of women and strangers in the city' and uses prostitution 'to pressure outmoded or inadequate conceptions of normative femininity and to acknowledge the increasingly hybridized life in an international commercial center'..$^{30}$ Phoebe's apprenticeship within a brothel suggests a tension between the idea that girls should be virginal and protected and the actual economic and sexual pressures that would expose them to commercial exploitation.

\section{IV}

I have focused primarily on representations of female children in this chapter in order to dispel the myth that there were no girl characters in English Renaissance drama. It is important to note, however, that female children were also almost certainly consumers of drama, not just its subject. They were, for example, probably among the audience members at the playhouses, as evidenced by Stephen Gosson including them in his description of the motley theatre-going crowd in his Plays Confuted in Five Acts. He laments,

If the common people which resort to theatres being but an assembly of tailors, tinkers, cordwainers, sailors, old men, young men, women, boys, girls, and such like be the judges of faults there painted out, the rebuking of manners in that place is neither lawful nor convenient, but to be held for a kind of libelling and defaming. ${ }^{31}$

Given Gosson's anti-theatrical bias, he may be indulging a propensity for hyperbole, but evidence from the Globe fire of 1613 also points to the presence of children in and around the theatre. Henry Bluett's letter on 4 July to his uncle Richard Weeks specifically mentions that the only person injured was a man 'adventuring in to save a child which otherwise had been burnt'. ${ }^{32}$ Whether the child in question was a boy or a girl, it seems quite likely that children of both sexes were a common sight at the public theatres.

Moreover, we need not see girls only as consumers of plays, but also as participants. Outside of the professional stage, evidence survives that a number of girls performed in private theatricals. David Wallace's and Caroline Bicks's studies of Mary Ward's convent schools demonstrate that her young pupils routinely participated in religious drama. Wallace focuses on Ward's biography, drawn from her letters and two extant biographical accounts, and Ward's reputation as the leader of a group of 
Catholic 'galloping girls' who founded schools for female children and established a religious house at Saint-Omer in France. Bicks, on the other hand, focuses on the practice at her schools of having the pupils perform in plays, ${ }^{33}$ and such a practice was not unique to Ward's underground Catholic community. In contrast to the lower classes, members of the gentry and aristocracy increasingly used institutional education beyond the petty schools as a way to train girls for womanhood. Options for schooling outside the home seem to have expanded in the seventeenth century with the establishment of several schools dedicated to the education of gentlewomen. The most well known of these is the Ladies Hall in Deptford whose pupils performed for Queen Anne in Greenwich on 4 May 1617. We know of them thanks to Robert White's Jacobean masque Cupid's Banishment, though we know little beyond what S. P. Cerasano and Marion Wynne-Davies postulate in their introduction to their edited version of the manuscript. Robert White was probably the master, and they suggest that 'it seems to have been a sort of high-class private academy that offered both academic studies and training in social skills'. ${ }^{34}$ The title page of the manuscript identifies the performers as 'younge Gentlewomen', marking them as members of the upper class, probably the daughters of members of the court judging from the fact that two of the performers, Ann Chalenor and Anne Sandilands, were Queen Anne's goddaughters. The speaking parts were all taken by men, including White himself, but the girls from the school, like Queen Anne of Denmark and her waiting women in Ben Jonson's more famous masques from the period, personated the roles of female nymphs. Clare McManus links the occasion of White's production with the queen's growing marginalisation in the court masques being performed at White Hall due at least in part to the controversial nature of female performance. At the same time, White positions Anne as the central spectator, potentially fragmenting courtly power between Greenwich, where the queen was located, and the court, where James's favourites had appropriated the right to demonstrate one's importance through spectacle. ${ }^{35}$ Although White's masque marginalises these aristocratic girl performers by relegating all but one of them to non-speaking roles, I would suggest that the allegorical nature of the masque and its representational modes actually make their status absolutely central.

Inspired and organised by Lucy Harington Russell, the masque was intended as a May Day celebration and, as Robert White explains, 'The ground of our plot is, choosing of a king and queen by Fortune's doom, which is a sport our little ladies can use on Candlemas night.' The female children in this masque, as in John Milton's A Mask Presented at Ludlow Castle, are 'little ladies' rather than 'girls'. The performance thus accords 
public significance to the youthful sports and revelries in which the young ladies annually engage at their school. What takes place within the spoken text of the play is a verbal sparring match between Diana and Cupid, the point of contention being whether the Virgin Goddess has a right to orchestrate the May Day match without Cupid's involvement. Unlike the lustful, amorous pairings brought about by Cupid, the mock marriage supposedly represents a truly 'chaste combination'.

The threat that Cupid poses to Diana and her nymphs is not so much to their chastity but to their sovereignty. They ultimately banish the saucy boy Cupid more because he threatens the female characters' control over their sexuality, and less because they reject love and sexuality in general. Cupid does not want to bring lovers together to promote love or procreation, but to 'vex' women and 'catch' them in his 'pitfall' (lines 112-13). Indeed, the terms in which the nymphs sing about refusing Cupid's version of love characterise his actions as filling their 'hearts with deep annoy' (line 129). Theirs is not the fiery, burning pain of a Petrarchan lover, but the incensed irritation of someone being aggravated by a peevish child; they label Cupid 'Venus's brat', a 'peevish ape' and 'fancy's child' (line 225). Incensed at his exclusion from the revels and at the orchestration of a marriage in which he has played no part, the childish Cupid responds in an appropriately childish manner: 'he stamps and storms', vowing 'vengeance' and cursing the 'coy dames' and 'beldames' whose 'squeamish, affected niceness' has rendered him irrelevant to love. This outburst of anger is apparently too much for Diana's temper, and she calls upon eight of her Dryads, played by the young pupils, to help her teach Cupid that 'Lust can never conquer Chastity'.

In a scene not unlike the masque in Shakespeare's Merry Wives of Windsor, when the child fairies surround and pinch Falstaff, Diana's wood nymphs surround Cupid and 'conquer' him with darts:

Enter the DRIADES, or eight wood nymphs. [They] rush out of a grove adjoining to the Mount, four off one side and four off another - with darts in their hands to shew they had a dart [that] could conquer CUPID - attired all in green garments, the upper part close to their bodies, the lower full and loose with silver and carnation lace from the breast to the foot, their arms half naked with bracelets of berries about them, [on] their heads garlands with [a] great variety of flowers, their hair disheveled, hanging careless about their shoulders, bare with puffs of tiffany round about [and] green pumps and gloves. After the music played over the first strain they fall into their dance. They environ CUPID in a figure and put ACTAEON'S head upon him. They fall off threatening him with their darts when he offers to resist. After many pretty figures they chase him forth into the woods by violence and banish him that presence. The nymphs sing in joy. CUPID is gone. 
Cupid's unmanning, signified not only by the nymphs' appropriation of his phallic darts for themselves, but also with the addition of Actaeon's horns to the boy god's head, demonstrates the nymphs' triumph. This is as much a political victory as a sexual one, and in the allegorical world of a masque, a very powerful one. These girls chase the boy off the stage, claiming it for themselves. The queen's goddaughters then make another allegorical gesture and present her with two gifts of needlework, one of an acorn and one of rosemary, a theatricalised act that McManus argues shows that 'embroidery could be a form of performance and an opportunity for the female creation and enactment of a text'. ${ }^{36}$ As the text of the masque explains, the acorn represents strength and the rosemary represents memory. ${ }^{37}$ The ' $A$ ' and the ' $R$ ' also represent the queen, 'Anna Regina', and her strength and memory. The ladies of Deptford Hall align themselves with the adult women for whom they performed against a masculinised vision of petulant childishness. The masque also takes the surprising step of giving the speaking role of Fortune to a female masquer, Anne Watkins, who McManus suggests may have been able to occupy a liminal space between her fellow female dancers and male actors due to her already liminal status as a female child, setting the stage for future youthful masquer Alice Edgerton to sing and speak in A Mask Presented at Ludlow Castle. McManus also indicates it may reflect the influence of French culture on Anne's court, since there was precedent for female performers like Mademoiselle de Sainte Mesme taking speaking parts in the Ballet Comique (1581). ${ }^{38}$

Although we do not know how widespread these kinds of schools were at the beginning of the seventeenth century, White's pupils were not the only ones who remain visible in the historical records. Laetitia Yeandle has found a letter providing evidence of a day and boarding school in Windsor that she dates to the first half of the seventeenth century. ${ }^{39}$ Written by Anne Higginson, the letter recommends a friend's establishment to Lady Ferrars of Tamworth Hall, describing their curriculum as including needlework, writing, reading and dancing, all for thirty-two pounds per year, with music lessons costing more.

It is just such a kind of school that Queen Eulalia establishes in Richard Brome's The Queen and Concubine, a play that features the highest concentration of young female children of any that I have found on the public stage. The girls' education includes semi-public entertainments that involve the boy actresses performing two songs, making it likely that they were choristers and offering a fictional version of the Ladies Hall performance. Set in Sicily, Brome's play takes as its central plot the false accusation of adultery made against Queen Eulalia by her husband Gonzago, who wishes to divorce her and marry his mistress, 
Alinda. Eulalia, who faces an unjust trial, brings together elements of Hermione and Griselda as a falsely accused wife who condones her husband's tyrannical behaviour and does not protest against his ruling. Sentenced to exile, Eulalia leaves the court and seeks refuge in the countryside, where she refuses to receive economic support from any of the king's courtiers because they have been explicitly forbidden to help her. Instead, she earns her own way first by working as a healer and then, after she has cured all their sicknesses, by running a girls' school. When the king and his new wife come to visit, Eulalia explicitly figures the girls' activities as a performance, asking the royal couple to 'note the Play / By which gain we lay work away' $(5.4$, sig. H7v). These 'poor entertainments', as Eulalia describes them, serve the double purpose of training girls to earn money and instilling a sense of gendered behaviour.

The initial formation of the school blurs the line between education and apprenticeship as the villagers offer their daughters as pupils. The initial class status of the girls differs from those attending the Ladies Hall, a fact reflected in Eulalia's focus on teaching them marketable skills. When asked if she can teach their daughters to handle bobbins, produce lace and perform the techniques for making braided ribbons, the queen makes it clear that the goal of her school will be to earn money for herself and her pupils. She agrees to 'teach all [their] children works to live on' as well as to give them a general knowledge of reading and music:

Something I have in Book, to help their knowledge,

And by practise give them literature.

Then when these serious works and studies toil us,

For Recreation, yet with equal skil,

Wee'l practice divers Instruments, Songs and measures,

That shall invite the Powers above to smile

On the content of which we them beguile.

$(4.1 \text {, sig. } \mathrm{F} 6 \mathrm{v}-\mathrm{F} 7 \mathrm{r})^{40}$

Eulalia's school brings together an aristocratic emphasis on recreation and well-rounded social accomplishments with pragmatic skills-based employment training. Historical evidence points to the establishment of charity schools in the later seventeenth century with similar goals to Eulalia's, but I have not found surviving evidence from this early in the century for schools aimed at the working and middling classes. ${ }^{41}$ The difference between historical charity schools and Eulalia's is that the fictional one was established as much out of charity to the queen as out of charity to the girls. She is in fact invited to take a house, make her choice of servants, take the children as pupils, and make her 'own Rates for Education' (4.1, sig. F7r). 
Although the queen sets up her school for a quirky reason, the curriculum is in line with the historical schools for girls at Deptford and Windsor. Eulalia brings out her scholars to demonstrate their skills in three key areas of female education: reading, writing and embroidery. The first girl has been learning to read, and Eulalia indicates that her lesson later will entail reading out loud. The second child, whom she addresses as 'Good Girl', shows off her sampler and has the colours admired by the visiting gentlemen from the court (sig. G4r). Needlework samplers were important material artefacts in the lives of young girls. Used to record favourite patterns, stitches and images, they offered a more affordable alternative to pattern books and could even double as a tool for teaching the $\mathrm{ABCs}$, since some featured embroidered alphabets. ${ }^{42}$ As Rozsika Parker points out, the emergence of women's signed and dated samplers in the sixteenth century corresponded to the emergence of women's diaries (some of which I will discuss in the next chapter), a parallel development that Parker attributes to the Protestant emphasis on individual salvation and the achievement of a secular work ethic. ${ }^{43}$ Although we cannot know exactly what would have appeared on the girl's sampler in Brome's play, Eulalia's instruction to copy out a flower on to it suggests that it was serving as a repository for decorative patterns, possibly to be used in creating the clothing that the queen and her students need to sell to make a living. Nonetheless the girl's needlework is not purely economic in its aims. Her activity is meant to reinforce appropriate feminine behaviour, as were the samplers that Parker has found featuring embroidered verses about 'bend[ing] unto another's will' in the hope the needleworker 'might learn both care and skill' ${ }^{44}$ Eulalia promises the girl that if she keeps her work clean, she 'shall be a good Maid' (sig. G4v). This promise of achieving moral value through work corresponds to a similar pattern that Ann Rosalind Jones and Peter Stallybrass have observed among representations of women's spinning: 'Through a shift from work to "virtue", the textile labour extracted by grim necessity from lower-class women spinners was displaced by a moral ideal prescribed for higher class women. ${ }^{35}$ Whereas all women were expected to spin, embroidery was largely the pursuit of upper-class women or professional embroiderers who belonged to guilds. The shift from work to virtue in Eulalia's comments figures the girl's activity firmly within a set of upper-class values. The elevated status of the pupils becomes even clearer when the third girl comes on stage and reveals that she is learning to write. Her enthusiasm for the task and eagerness to learn 'joyn-hand' prompt a mild rebuke. Eulalia tells her, 'No child, you must not Joyn-hand yet: you must your letters and your minums better first. Take heed, you may Joyn- 
hand too soon, and so mar all: still youth desires to be too forward' (sig. G4v).

One imagines the young female playwrights Rachel Fane, ${ }^{46}$ Jane Cavendish and Elizabeth Brackley might well have been just such little girls, eager to learn but being admonished to keep within acceptable boundaries. Of the surviving plays written by women in the sixteenth and seventeenth centuries, a significant number were written by young women, including Jane Lumley's translation of Iphigenia at Aulis. Youth was not a prerequisite for early modern women's literary production although Rachel Speght was only eighteen when she penned A Mouzell for Melastomus, Elizabeth Cary was twenty-eight at the publication of her play The Tragedy of Mariam (1613) and Aemilia Lanyer was fortytwo when she published Salve Deus Rex Judeaorum (1611) - but young women writers do seem to have had a special affinity for the dramatic genre, despite having to play out that relationship in spaces outside the public theatre. As scholars have been looking to expand our notion of what counts as early modern drama, private theatricals have proven a rich space for investigating the various forms that female performance could take, with Alison Findlay organising her study of female playing spaces through categories like homes, gardens, courts, sororities and cities, and Sophie Tomlinson examining Stuart drama in such a way that she can trace women's performances from early seventeenth-century masques through to Restoration public-stage plays. ${ }^{47}$ Girl writers were by definition exceptional but they form part of that story. Fane's various theatrical entertainments and Cavendish and Brackley's closet drama The Concealed Fancies do not directly represent female childhood, but they indicate that girls were influenced by and could produce drama.

Rachel Fane is of particular interest because she wrote as a child and for child performers. As the granddaughter of the well-known Lady Grace Mildmay and daughter of Sir Francis Fane and Lady Mary Mildmay, Rachel Fane grew up in a house with a library that included playbooks by Ben Jonson, Beaumont and Fletcher, and William Davenant. ${ }^{48}$ We know she had a particular interest in drama thanks to the survival of several of her notebooks, which include a complete masque and several entertainments written around the time when she was thirteen and living at her family's home of Apethorpe. The volume includes a rich variety of materials dating to the period 1625-30, including a cast list that makes it clear that she wrote the pieces to be performed by her siblings and visiting cousins for their adult relations. ${ }^{49}$ She notes the children's names and their ages, all of which are between five and twelve years old. ${ }^{50}$ Fane's most elaborate work, which Marion O'Connor titles May Masque at Apethorpe (1627), offers an extraordi- 
nary example of children's writing from the period. Not only does Fane draw from the court masque tradition and include mythological figures like Urania, the content of her play grapples with ideas about love and power, ending with a dance arranged by Rachel. The script includes detailed descriptions of costumes and stage directions. For example, it opens with the entrance of a jester with a garland on his shoulders, a shepherd in a grey coat carrying a dog in one hand and a sheephook in the other, a man in a red waistcoat and grey breeches, and others following with ladders and tools. The next scene features nymphs dancing with Urania and the goddess Venus's command, and culminates with Urania singing a song of Rachel's devising. Another separate short piece features a fantastical man with a magical wishing chair that allows him to change the seasons, and his constant dissatisfaction with the weather, whether finding summer too hot or winter too cold, seems to comment on the impossibility of being satisfied in the mortal world, as the fantastical man finds himself wishing for night and sleep to be free from the day's misery.

Although clearly a young amateur, Rachel does demonstrate a clear theatrical imagination in the stage directions for a lost pastoral masque in which we see her grappling with the constraints of planning her desired spectacle with limited resources. She notes that 'for want of actores' she has decided to replace the antics with Robin Goodfellow, who will come out with a 'flash of fier' to scare the allegorical figure of Nobody and his company. She notes that she plans to follow that scene with one involving Daphne and Apollo that will be followed with eight little fairies bringing in a bower of three 'litle children' who dance for the god and goddess, only to be scared away with horns. Next, she indicates Diana and her nymphs will enter and dance, followed by the speech of a nobleman. The plot of the entertainment is hard to follow, but the intricate details, complete with stage pyrotechnics, reveal an ambitious vision. Unfortunately, the play that probably would have been the most legible and of the most interest to contemporary scholars only exists in a very small fragment. Opening with a focus on a duchess and her son, the piece reads like a public drama (the genre is unclear), but only two scenes have survived. The note 'I lost the rest' in the corner of the folio page containing the fragment indicates that Fane compiled her pastimes for children as an adult and that there may well have been other lost theatrical pieces.

Despite the fragmentary nature of Fane's literary corpus, she still offers a fascinating glimpse into the imagination of an early modern girl. As Kate Chedgzoy points out, Fane evokes 'the possibility of children's cultural agency'; positioned at the 'boundaries of childhood as a 
chronological stage', Fane offers a rare female counterpoint to the constructions of girlhood by men that dominated professional drama. ${ }^{51} \mathrm{We}$ do not know how common it was for female children to participate in family drama, read playbooks or go to the theatre, but girls like Rachel Fane suggest we should be attuned to more than just professional playwrights. Girls are only absent from English Renaissance drama if we limit ourselves to the public stage, and then only if we take a canonical view of which early modern plays count.

\section{Notes}

1. Catherine Belsey, 'Shakespeare's Little Boys: Theatrical Apprenticeship and the Construction of Childhood', in Bryan Reynolds and William N. West (eds), Rematerializing Shakespeare: Authority and Representation on the Early Modern English Stage (Basingstoke: Palgrave, 2005), p. 56.

2. Mark Lawhorn, 'Children in Shakespeare's Plays: An Annotated Checklist', in Kate Chedgzoy, Susanne Greenhalgh and Robert Shaughnessy (eds), Shakespeare and Childhood (Cambridge: Cambridge University Press, 2007), p. 233.

3. Margaret L. King, 'Concepts of Childhood: What We Know and Where We Might Go', Renaissance Quarterly 60 (2007), p. 389.

4. Cited in Sharon Hamilton, Shakespeare's Daughters (Jefferson, NC: McFarland, 2003), p. 5.

5. David Bevington, From Mankind to Marlowe: Growth of Structure in the Popular Drama of Tudor England (Cambridge, MA: Harvard University Press, 1962), p. 65.

6. Ibid. pp. $78-9$.

7. For a study of the way the children's companies portrayed childhood, see Edel Lamb, Performing Childhood in the Early Modern Theatre: The Children's Playing Companies (1599-1613) (Basingstoke: Palgrave, 2009). As Lamb shows, the actors were very pointedly constructed as children, even more so than as boys or youths. 'What is most interesting', she writes, 'is the way the two companies define the players as children regardless of their biological age' (p. 3).

8. Lucy Munro, Children of the Queen's Revels (Cambridge: Cambridge University Press, 2005), p. 2.

9. Gerald Eades Bentley, The Jacobean and Caroline Stage: Dramatic Companies and Players, Vol. 2 (Oxford: Clarendon, 1941), p. 283.

10. Hugh Cunningham, Children and Childhood in Western Society since 1500 (New York: Longman, 1995), p. 2.

11. It is arguable that Nicholas Udall's Ralph Roister Doister (c. 1553, printed 1567) might also belong in this group, since the servants are young, unmarried and addressed as 'naughty girles' by their mistress Constance Custance. Although I am omitting Tibet Talkapace and her fellow serving women, I definitely see them as part of this phenomenon. The same is true of Lewis Wager's The Life and Repentaunce of Marie Magdalene (1567), which 
repeatedly refers to its title character as a 'gentlewoman' but attributes her wanton materialism to her indulgent upbringing. I am also excluding Lomia, the 'natural' girl from Common Conditions, because her age is ambiguous and her status as a girl seems to be determined largely by her cognitive disability.

12. Nice Wanton, in The Tudor Interludes Nice Wanton and Impatient Poverty, ed. Leonard Tennenhouse (New York: Garland, [1560] 1984), pp. 65-125. All further quotations come from this edition.

13. Although Philippe Ariès acknowledges that English girls attended petty schools, he downplays petty schools in comparison to grammar schools, which girls did not attend. See his Centuries of Childhood, trans. Robert Baldick (New York: Vintage, 1962), especially pp. 137-338.

14. Jacob and Esau (London, 1568), sig. E2v.

15. Among the select group of scholars who have worked on the play, its theological position, date and authorship have been hotly contested topics. The play was entered into the Stationers' Register in 1557-8 to Henry Sutton but does not appear to have been printed until 1568, when Henry Bynneman published A mery and wittie Comedie or Enterlude, newely imprinted, treating vpon the Histories of Iacob and Esau, taken out of the xxii. Chap. Of the booke of Moses entituled Genesis. For the authorship question, see Leicester Bradner, 'A Test for Udall's Authorship', Modern Language Notes 42 (1927), pp. 378-80. On the issue of theology, the central question has been how rigidly Calvinistic the play was. See Helen Thomas, 'Jacob and Esau: "Rigidly Calvinistic"?', Studies in English Literature, 1500-1900 9 (1969), pp. 199-213. Paul Whitfield White has examined the way that the play's language echoes the Great Bible, the standard version of scripture in England up to 1560, and the way its position on the doctrine of election reflects a popular, moderate position held by Protestant reformers like John Bradford. See his 'Predestinarian Theology in the Mid-Tudor Play Jacob and Esau', Renaissance and Reformation 24 (1988), pp. 291-302. More recent work has looked at the play's transitional role between Catholic mystery cycles and professional drama, as in Dalia Ben-Tsur's 'Early Ramifications of Theatrical Iconoclasm: The Conversion of Catholic Biblical Plays into Protestant Drama', Partial Answers: Journal of Literature and the History of Ideas 3 (2005), pp. 43-56. Another exciting approach to the play comes from Michelle Karen Ephraim, who interprets it in light of its Elizabethan publication context, thinking about the way Rebecca and Deborah might be seen as figures of Elizabeth I, either on the cusp of her reign in 1558 or into her reign in 1568. See her 'Jewish Matriarchs and the Staging of Elizabeth I in The History of Jacob and Esau', Studies in English Literature, 1500-1900 43 (2003), pp. 301-21. However, her reading depends upon an Elizabethan context, and the most recent article on the play by John E. Curran argues that its theology emerges out of a specifically Edwardian context. See 'Jacob and Esau and the Iconoclasm of Merit', Studies in English Literature, 1500-1900 49 (2009), pp. 285-309.

16. Elisabeth Schüssler Fiorenza, But She Said: Feminist Practices of Biblical Interpretation (Boston: Beacon Press, 1993), p. 8.

17. Jane Tylus has argued that Petrarch positions his translation as a correction 
or renunciation of Boccaccio and that his text, aimed at male scholars of Latin rather than wives, offers a more conservative view. Jane Tylus, 'Translating Griselda: Holy Women and the Vernacular in Renaissance Italy', paper presented at the Center for Medieval and Renaissance Studies, The Ohio State University, Columbus, 5 November 2010.

18. Pamela Allen Brown, Better a Shrew than a Sheep: Women, Drama, and the Culture of Jest in Early Modern England (Ithaca: Cornell University Press, 2003), p. 190.

19. See Anne M. Hasselkorn, 'Griselda, Renaissance Woman', in Hasselkorn and Betty Travitsky (eds), The Renaissance Englishwoman in Print: Counterbalancing the Canon (Amherst: University of Massachusetts Press, 1990), pp. 211-23; Lee Bliss, 'The Renaissance Griselda: A Woman for All Seasons', Viator: Medieval and Renaissance Studies 23 (1992), pp. 301-43; Felicity Dunworth, “"A Bosom Burnt Up With Desires”: The Trials of Patient Griselda on the Elizabethan Stage', Paragraph 21 (1993), pp. 330-53. Ursula Potter, on the other hand, suggests Phillip's play may have been addressed to a specific daughter - Queen Elizabeth, whose mother had been treated harshly by Henry VIII. See her 'Tales of Griselda and Henry VIII', Early Theatre 5 (2002), pp. 11-28.

20. John Phillip, The Comodye of Pacient and Meeke Grissill, Malone Society Reprints (Chiswick: Charles Whittingham \& Co, [1569] 1909).

21. The mock wedding's role in the Griselda legend comes uncomfortably close to incest, as Louise O. Vasvári points out. See her 'The Story of Griselda as Silenced Incest Narrative', Corónica: A Journal of Medieval Spanish Language, Literature, and Cultural Studies 35 (2007), pp. 139-56.

22. Henry Chettle, Thomas Dekker and William Haughton, The Pleasant Comodie of Patient Grissill, Tudor Facsimile Texts, ed. John Farmer (New York: AMS Press, [1603] 1970), sig. B3r.

23. This sentimental use of a girl as victim would later reach its fullest fruition in Robert Baron's closet drama Mirza (1655), which places the murder of the sultan's daughter Fatima at the centre of its exploration of tyranny. Unlike Lenchy, who would have been played by a boy actor on the public stage, Fatima was clearly written to be read aloud, dispensing with some of the traditional constraints of needing a boy actress who was experienced enough to play such a large role. Dramatising the same events as John Denham's The Sophy, Mirza is likely to become an important play for those scholars who are currently working on representations of Islam and the East and deserves fuller consideration than I am able to give it here.

24. A Larum for London, ed. W. W. Greg, Malone Society Reprints (Oxford: Oxford University Press, [1602] 1913).

25. Although relatively obscure today, it was highly popular at the time of its first performance at Cambridge in 1615, with King James reportedly liking it so well that he saw it twice. It was entered into the Stationers' Register in 1615 , but 1630 is the earliest extant edition. For an account of its publishing history and subsequent Restoration translations, see Edward Frederick John Tucker (ed.), Ferdinando Parkhurst's Ignoramus, the AcademicalLawyer: A Critical Edition (New York: Garland, 1987), pp. xxiii-lviii.

26. George Ruggle, Ignoramus Comoedia coram Regia Maiestate Iacobi Regis Angliae (London, 1630). 
27. Ilana Krausman Ben-Amos, Adolescence and Youth in Early Modern England (New Haven: Yale University Press, 1994), p. 135.

28. K. D. M. Snell, 'The Apprenticeship of Women', in Annals of the Labouring Poor: Social Change and Agrarian England, 1660-1900 (Cambridge: Cambridge University Press, 1985), pp. 270-318.

29. For an analysis of Fletcher's sources and the relationship between the 1625 manuscript version of the play and the version in the 1647 Folio of Beaumont and Fletcher's plays, see 'Textual Introduction' in A Critical Edition of John Fletcher's The Humorous Lieutenant, ed. Phillip Morrow Oxley (New York: Garland, 1987), esp. pp. 1-17. All quotations are from this edition.

30. Jean E. Howard, Theatre of a City: The Places of London Comedy, 1598-1642 (Philadelphia: University of Pennsylvania Press, 2007), p. 161.

31. Stephen Gosson, Plays Confuted in Five Acts (London, 1590), in S. P. Cerasano and Marion Wynne-Davies (eds), Renaissance Drama by Women: Texts and Documents (New York: Routledge, 1996), p. 162.

32. Quoted in Maijja Jansson Cole, 'A New Account of the Burning of the Globe', Shakespeare Quarterly 32 (1981), p. 352.

33. See David Wallace, 'Periodizing Women: Mary Ward (1585-1645)', Journal of Medieval and Early Modern Studies 36 (2006), pp. 397-453, and 'Holy Amazon: Mary Ward of Yorkshire, 1583-1645', Strong Women: Life, Text, and Territory 1347-1645 (Oxford: Oxford University Press, 2011); Caroline Bicks, 'Producing Girls in Mary Ward's Convent Schools', in Naomi Miller and Naomi Yavneh (eds), Gender and Early Modern Constructions of Childhood (Aldershot: Ashgate, 2011), pp. 139-53.

34. Introduction to Robert White, Cupid's Banishment, in S. P. Cerasano and Marion Wynne-Davies (eds), Renaissance Drama by Women: Texts and Documents (New York: Routledge, 1996), p. 77.

35. Clare McManus, Women and Culture at the Courts of the Stuart Queens (New York: Palgrave, 2003), pp. 179-80.

36. Ibid. p. 192.

37. Cerasano and Wynn-Davies, Introduction to Robert White, Cupid's Banishment, p. 77.

38. McManus, Women and Culture, pp. 185-6.

39. Laetitia Yeandle, 'A School for Girls in Windsor', Medieval and Renaissance Drama 17 (2005), pp. 272-80.

40. Richard Brome, The Queen and Concubine, in Five New Plays (London, 1659).

41. For information about charity schools, see Sara Mendelson and Patricia Crawford, Women in Early Modern England, 1550-1720 (Oxford: Oxford University Press, 1998), pp. 90-1, and M. G. Jones, The Charity School Movement: A Study of Eighteenth Century Puritanism (Hamden: Archon, 1964), pp. 98-9.

42. See Santina Levy, 'Embroidery, Renaissance to Rococo', in The Victoria \& Albert Museum's Textile Collection: Embroidery in Britain from 1200-1750 (London: Victoria \& Albert Museum, 1992), p. 18.

43. Rozsika Parker, The Subversive Stitch: Embroidery and the Making of the Feminine (London: Women's Press, 1984), p. 86.

44. Quoted in Parker, The Subversive Stitch, p. 13. 
45. Ann Rosalind Jones and Peter Stallybrass, Renaissance Clothing and the Materials of Memory (Cambridge: Cambridge University Press, 2000), p. 92.

46. I am grateful to Kate Chedgzoy for being the first to call my attention to Rachel Fane's manuscripts.

47. Alison Findlay, Playing Spaces in Early Women's Drama (Cambridge: Cambridge University Press, 2006), and Sophie Tomlinson, Women on Stage in Stuart Drama (Cambridge: Cambridge University Press, 2004).

48. See Marion O'Connor, 'Rachel Fane's May Masque at Apethorpe, 1627', English Literary Renaissance (2006), p. 93.

49. Caroline Bowden offers a general description of the manuscripts' physical state and contents in 'The Notebooks of Rachel Fane: Education for Authorship', in Victoria E. Burke and Jonathan Gibson (eds), Early Modern Women's Manuscript Writing: Selected Papers from the Trinity/ Trent Colloquium (Aldershot: Ashgate, 2004), pp. 157-80. See also O’Connor, 'Rachel Fane's May Masque', pp. 93-4.

50. Rachel Fane, Notebooks, Centre for Kentish Studies, MS U269 F38/3.

51. Kate Chedgzoy, 'Introduction: "What, are they children?"', in Chedgzoy, Susanne Greenhalgh and Robert Shaughnessy (eds), Shakespeare and Childhood (Cambridge: Cambridge University Press, 2007), p. 16, p. 24. 


\section{Voicing Girlhood: Women's Life Writing and Narratives of Childhood}

In 1598, an eight-year-old Anne Clifford composed a letter to her father George, requesting his blessing and assuring him of her daughterly duty. Although brief, the letter was written on beautifully decorated paper with a border of colourful flowers, clearly indicating that it was an elaborate offering rather than a casual note. She wrote:

I humbly intreate your blessing and euer comend my duety and seruice to your Lo: praying I may be made happy by your loue I comend my seruice and leaue my trobling of your Lo: being your

\section{Daughter in all obedient duety Anne Clifford ${ }^{1}$}

The tone of this letter is difficult to determine. The formality of addressing her father as 'your Lordship' follows early modern protocols of respect between aristocratic children and their parents, and it could indicate either a coldly official relationship or warm daughterly affection. It could be the writing of a girl going through the motions of pleasing an adult, or it could be the genuine expression of a passionate child. My own initial reaction to the letter was that it gives us very little insight into the child Anne's subjectivity, but I had to rethink my perspective when I came across a brochure for a June 2012 embroidery retreat in honour of Lady Anne Clifford where the internationally renowned needleworkers Phillipa Turnbull, Jane Nicholas, OAM, and Meredith Willett offered to teach students the techniques necessary to reproduce designs from early modern Britain, including one inspired by the flowers on Anne's letter to her father. The brochure describes the letter not as the formal exercise that I initially saw, but as the work of 'a lonely 8 year old Lady Anne to her father, imploring him not to be away from home so much and to be a better father'. ${ }^{2}$ As an academic, I am bound by scholarly conventions that prevent me from making such 
bold claims about Anne's feelings, but the brochure's interpretation made me pause and realise that my own dismissal of the letter stemmed from preconceived ideas about what children's writing sounds like and what forms of expression their affection should take. I cannot prove that Anne's letter was an impassioned plea for her father to love her, but I also cannot prove that it was not. It is precisely because I want to hear the personal, intimate voice of Anne Clifford as a child that I find the letter's formality disappointing.

For me, as for other scholars of early modern girls and women, the 'desire to speak with the dead' remains a powerful but ultimately elusive fantasy. ${ }^{3}$ The feminist recovery projects of the 1970s and 1980s have given us a much richer variety of women's texts from which to choose, including some texts by children like Anne Clifford, but those voices do not offer unfettered access to the lived experiences of sixteenth- and seventeenth-century women. If the female writers of letters, diaries, mother's advice manuals and religious meditations have the power to speak to us, they are not speaking in unmediated ways. ${ }^{4}$ They are fashioning their lives according to a complex set of generic and cultural influences, ultimately telling us their stories via an inherited set of narrative conventions. Well before any of these women put quill pen to paper, they would have encountered ideas about what a woman's life story looks like, and those ideas would have shaped the narrative possibilities of their own speaking voices.

This is especially true of girls. Although examples of early modern girls' writing have survived, they often display a certain amount of opacity. In addition to her plays, Rachel Fane left behind a notebook that included copies of Latin and Spanish grammars, French translation exercises, and a list of behaviours and traits that are 'comly for a virgin', including platitudes such as 'A kinde nature winneth loue, but a stubborne spirit is a plague to reason'. ${ }^{5}$ Her manuscripts tell us much about her education, but they reveal a limited amount about how she felt about that education and how she saw her identity as a female child. Equally conventional are the 'Verses made by a Maid under 14', published with two other poems in the 1650s. Robert C. Evans has praised the writer's grasp of scripture, her strong use of iambic pentameter and her ability to avoid forced rhyme, ${ }^{6}$ but her identity remains elusive and her sentiments are largely no different from those expressed in adult women's religious verse. She maintains the expected disdain for 'this world' as 'filthy drosse' and precociously calls for the Lord to 'Come quickly ... / That I from sin may turn away'. ${ }^{7}$ What we see in this girl's poem is her willing assimilation into early modern religious discourse, an important part of the experience of many early modern children. 
Though the writer does not dramatise her identity as a child, it was clearly important to the publisher to mark the verses by the 'Maid under 14 ' as written by a young girl, regardless of the content, and that signals that there was a cultural value to advertising a text as emanating from a female child. The book capitalises on the poet's youth in order to render the otherwise conventional sentiments remarkable because they demonstrate such strong piety in one so young. The poem does not create a sense of great intimacy between the audience and the poet, but that was not its goal. Moreover, as Kate Chedgzoy argues, Rachel Fane's copying of platitudes is at odds with the vivacious and imaginative literary works that she produced, which suggests that the copying of such 'blandly formulaic advice' may not have had as deep an influence as it might seem at first blush, and that 'the uses to which literacy may be put cannot be so easily contained and controlled'. ${ }^{8}$

In looking at young girls as writers, I find myself caught in the questions about children and mimesis that Michael Witmore has explored with regard to child performers both in Elizabethan pageants and on the public stage. ${ }^{9}$ Early modern culture clearly understood that children could memorise and repeat elaborate texts, but their skills raised questions about whether they were simply mimicking the language they had heard (like parrots) or truly understood (and believed) the content. Even when approaching historical material with a desire not to map contemporary assumptions about what children should sound like on to the past, it can be hard to maintain objectivity. At its heart, this book seeks to replace an absence with a presence, both the absence of girls from contemporary critical discourse and the absence of girls in our historical view of early modern literature and culture. To do so, however, risks mystifying the processes through which girls became speaking subjects. Recent work on gender and autobiography have reconfigured the self who writes as a discursive production dependent on linguistic, generic and cultural factors. ${ }^{10}$ This chapter accordingly seeks to pay attention to narrative conventions in order to examine female life stories without resorting to essentialist models wherein young women's writing produces transparent lenses into female experiences. Instead, what interests me is the way that early modern texts produced girls' perspectives in order to label them as girls' perspectives. The women whose lives I explore in this chapter largely see their childhoods as conventional and figure their own agencies in terms of their ability to conform to proper gender roles. This is partly a function of the fact that so much of women's life writing focuses on members of the aristocracy or gentry, and the writers have a class-based investment in maintaining the status quo. Even a woman like Anne Clifford, who stood firm against James I's 
attempts to coerce her into giving up her claims to her father's property, figures her actions as operating within conservative patriarchal standards rather than against them. These texts sought to stabilise the category of the 'girl' by projecting her into the past, writing girlhood as a bounded time of life when girls were learning about the world around them but had not yet been granted a social voice.

Nonetheless, women's life writing, with its attention to the age differences between girls and women, still poses a challenge to the tripartite model of the early modern sex-gender system. Women's coming-of-age stories make it clear that an idea of female childhood existed and that, just as boys became men, girls became women. These texts also clearly reveal that, while marriage was an important event in women's lives, the maturation process involved a wide variety of cultural moments, from putting on a girl's first pair of stays to experiencing a difficult sickness to reading with her governess. These women's texts, however, differ from male-authored drama in their figuration of childhood; in women's life writing, the transgressive girlishness of the stage remained largely undesirable. To look beyond the tripartite model and the 'maid, wife, widow' schema is not to insist that early modern women were not bound by patriarchal constraints; when women remember their childhoods, they are generally using them to construct a sense of themselves as part of the existing social fabric rather than seeking to rend that fabric apart. Consequently, they see girlhood as part of a narrative, with female children fulfilling narrative functions. In some works, the progression from childhood to adulthood provides the text with an organising principal, beginning with infancy and childhood and ending with old age or death. More often, however, the writers use girlish experiences to explain how the woman in question became the woman she is, making her girlish self prefigure the future woman. Her positive traits become evidence for proving the worth of the adult woman as well as offering an ideal model for how young girls should be raised. Women's lives in these texts were made as much as they were experienced. By putting autobiographical works in dialogue with each other, this chapter sees life writing as part of a constellation of generic strategies for narrating female lives that worked quite differently from the tripartite model. ${ }^{11}$

\section{।}

Although women's autobiographies and diaries are relatively scarce until the later seventeenth century, several manuscripts contain descriptions of girlhood, including an autobiographical letter by Margaret 
Clifford, Lady Grace Mildmay's autobiographical reflections, Lady Anne Clifford's diary, and Rose Throckmorton's Certain Old Stories. Along with descriptions of her own youth, Anne Clifford also provides several tantalising glimpses of her young daughter Margaret. Although genre helps account for the presence of young girls in life writing, the inclusion of information about these women's childhoods should not be mistaken for an established generic convention. The tradition of biographies beginning $a b$ ovo, as Tristram Shandy would say, had not been established. To include a description of children's experiences was a conscious choice that implied childhood mattered in the formation of the adult. Today this might be an assumption, but in the seventeenth century it was not.

Rather than writing in a well-established genre, women would have been drawing from a variety of complementary traditions. Margaret Clifford (Anne's mother) explicitly saw herself as blazing new ground when she wrote an autobiographical letter to her chaplain Dr Leyfield. She describes herself as adapting the masculine tradition of dividing men's lives into seven ages and matches that up to 'The Dance of the Pilgrimage of Grief' so that the story of her life becomes a series of trials and tribulations. 'Men commonly divide their life by sevens,' she writes, 'so mean I, to divide mine well known most of them to thee.' ${ }^{12}$ She breaks off after five stages, since she sees herself as in the middle of that fifth stage, and her life story leads up to a plea to God that the rest of her life be free from the sorrow of the first five stages. James Daybell sees her letter as a 'vehicle for self-analysis', ${ }^{13}$ which it is, but it is also an attempt to construct the female life cycle as a series of progressive stages that Margaret hopes will finally culminate in happiness and salvation. Her method of organising those stages, however, does not follow the 'maid, wife, widow' schema that I discussed extensively in Chapter 1 but instead offers a more nuanced breakdown of the events that Margaret saw as shaping the course of her fate. Although she mentions her marriage and children, Margaret breaks down the stages of her life according to her emotional responses to difficult events with the central purpose of enabling her to shape the remaining part of her life. 'Let me cry to God', she writes, 'for the mercy of his sons blood to spare me from farther plagues and turn me from my sins by the hands of mercy, that I may recover my strength before I go hence and show his judgment and mercy to the generation of my lady, for I fear to speak of my griefs that follow the fifth seventh. ${ }^{14}$

Given such a statement, one might expect that the story of her life detailed her various transgressions, but in Margaret's account, her sins manifest themselves not by her actions but by the tribulations she 
faces, such as her two sons' deaths. She represents that misfortune as a continuation of her bad luck. When she comes to the fourth stage, she notes, 'it seemed all would turn with a contrary note of joy. Time took and brought many things of trouble away ... but straight I went aside with my old note of sorrow.' ${ }^{15}$ That note of sorrow began in her infancy, what Margaret calls her 'first seven', explaining that she 'came as unlooked for', or early, and that because of her mother's death, she and her siblings 'were scattered and put to the disposal of friends'. Despite such a melancholy beginning, marked by several 'strange' and 'divers' kinds of sicknesses, Margaret indicates that the kindness of her caretakers from her early years has continued over the years and stands 'as the chiefest of [her] happiness'. ${ }^{16}$ And according to Margaret, her later childhood only made her less comfortable in her surroundings. The remarriage of Margaret's father and her re-entrance into his household signals the entrance into what she sees as the second stage of her life. In addition to the death of her beloved brother Edward, she notes that 'according to the course of times there was changes of manner from my childs life'. Those changes seem particularly caught up with the treatment she received from her father's new wife, whom she notes that she 'fear'd', and from her brother John Russell, who she notes 'dealt more unkindly with my childish tender deeds, than I expected'. She provides no details, but interestingly does attribute falling ill with green sickness to his 'unbrotherly dealing'. ${ }^{17}$

It does seem true that the Russell family was not as warm and loving as Margaret would have liked, and her own marriage was turbulent. ${ }^{18}$ She and George Clifford separated in 1600 in part due to his economic extravagance as he became embroiled in court life (she writes in the letter that exchanging 'his country pleasures' for the 'pleasant delights of court' resulted in him wasting their 'land and substance'). ${ }^{19}$ She does end the letter on a potentially hopeful note, recording the conception and birth of her daughter Anne and praising God, but within the text of the letter, she clearly focuses on the negative aspects of her life as part of her plea for future prosperity and grace.

How a text represented female childhood often depended upon why a text represented it, and class status deeply inflected Margaret Clifford's letter as well as the autobiography of Grace Mildmay and the diary of Margaret's daughter Anne Clifford. Unlike Margaret, Mildmay and Anne both describe their girlish selves as spectators. Mildmay's autobiographical papers, extracts of which have been published in Linda Pollock's With Faith and Physic, offer insights into ways that early modern culture imagined the transitional period between female infancy and adult womanhood. ${ }^{20}$ Admittedly, Mildmay's life cannot 
be taken as representative. Not only was she in many ways atypical of girls even in her own social class, ${ }^{21}$ she also frames her memories to suit her principles. Though she holds up her family as an instructional model, her childhood was decidedly class and gender specific. The focus of her education was on preparing her for the future role of elite wife, and her educational advice effectively excludes working- and middlingclass children from the category of 'children'. Nevertheless, Mildmay's manuscript offers a retrospective portrait of one girl's experience, and her narrative reveals just how much ideas about girlhood could influence the way early modern people perceived themselves and the world around them.

Mildmay's love for her governess clearly demonstrates the close affective ties that could form between girls and their female caretakers. As the niece of Mildmay's father, Mistress Hamblyn was raised by Mildmay's mother Anne and later entrusted with the education of all three of the family's daughters. According to Mildmay, Mistress Hamblyn 'was of an excellent quick spirit and pleasantly conceited, so that she won my eldest sister and me to be in love with her and to delight in all her speeches and actions'. ${ }^{22}$ Mildmay's language suggests an intense relationship between teacher and student, and her use of the word 'love' does indeed seem to be accurate. Mildmay writes:

I delighted so much in her company that I would sit with her all the day in her chamber and by my good will would never go from her, embracing always her rebukes and reproofs ... And when I was not with her she would be sure to be with me, at my heels to see where and with whom I was and what I did or spake. ${ }^{23}$

Although these claims seem somewhat hyperbolic (presumably they were occasionally separated), they reveal a strikingly human picture of a child seeking adult approval and attention. The girl who became Grace Mildmay was glad to be watched and monitored closely by her beloved governess, and she does not seem to have resented being taught to be submissive. Even when Mistress Hamblyn seeks to ward off idleness, Mildmay describes her lessons as welcome diversions rather than impositions:

And when she did see me idly disposed, she would set me to cipher with my pen and to cast up and prove great sums and accounts, and sometimes set me to write a supposed letter to this or that body concerning such and such things, and other times set me to read in Dr. Turner's herbal and in Bartholomew Vigoe, and other times she set me to sing psalms and sometimes set me to some curious work (for she was an excellent workwoman in all kinds of needlework, and most curiously she would perform it). ${ }^{24}$ 
We can see in her language some traces of childhood obstinacy. She may emphasise her obedience, but she also reveals that she did not always get her way. Since she could not always be with Mistress Hamblyn, there were clearly times when she experienced an absence of her 'good will'.

Mildmay portrays Mistress Hamblyn as both the product of an ideal female education and its provider. Having been well brought up by Anne Mildmay, the governess had attained the tangible knowledge of keeping accounts and producing compositions as well as acquiring the intangible traits of 'wisdom and gravity'. She could:

give a right answer and true judgment of most things and give wise counsel upon any occasion. And she could apprehend and contrive any matter whatsoever propounded unto her most judiciously and set her mind down in writing either by letters indited for otherwise as well as most men could have done. She had (also) good knowledge in physic and surgery ... She scoffed at dalliance, idle talk and wanton behaviour, appertaining thereunto with a touch of a caveat to take heed therof. ${ }^{25}$

In imitation of her own childhood caretaker, Mistress Hamblyn seeks to instil in her pupils these same skills and moral dispositions, while her replication of her own gendered education uncovers the fraught position of the woman teacher. She can perform tasks as well as most men and assumes a great deal of power within the student-teacher relationship, and yet she reproduces the conservative values and gender relations that her own excellence challenges.

Mistress Hamblyn's methods for inculcating conventional feminine behaviour simultaneously deny and authorise the female child's agency. On the one hand, the fastidious governess counsels her young charges to think of themselves as always being observed, and even when alone, to behave 'as if all the world did look upon' them. ${ }^{26}$ Stressing the panoptical state of aristocratic society, where the mere appearance of misconduct could ruin a woman's reputation, the governess instructs her cousin to shun the company of lewd and idle people and to behave in a manner appropriate for her gender and class status.

That said, the way Mildmay becomes conditioned to view herself as always being under surveillance is by surveying others. In her allusion to Mistress Hamblyn's childhood, Mildmay praises her governess for subjecting all the people she meets to harsh scrutiny. Even from her youth, she has 'made good use of all things that ever she did read, see or hear and observed all companies that ever she came in'. ${ }^{27}$ What interests me about this description is the extent to which it figures girlhood as a time of vigorous observation. Although intended to produce a submissive woman, the use of exemplarity as a teaching tool invites children to condemn adult conduct. Whereas we so often see adults looking at 
female children in conduct manuals, in Mildmay's autobiography we see female children encouraged to look at and judge adults. The governess actively calls her young pupil's attention to the inhabitants of her father's house, pointing out an ignorant man who 'gloried in his own wit' only to make a fool of himself at dinner and a woman with 'a subtle spirit, full of words and questions ... a busybody and a meddler in matters which concerned her not' ${ }^{28}$ She also encourages Mildmay to observe the 'monstrous spectacle' of a couple whose licentious behaviour with other men and women undoes the sanctity of their marriage. One can easily imagine a young Mildmay sitting at her parents' table, watching the adults, listening to their conversations and using Mistress Hamblyn's titbits of gossip to decipher their behaviour.

For a text that places so much emphasis on controlling the books available to children, Mildmay's writing seems deeply uninvested in keeping them ignorant of vice. Mildmay claims that her father discharged any servants who behaved in a 'lewd and impudent' manner that might corrupt his daughters 'by evil examples', and she reports seeing her father 'scourge a young man naked from the girdle upwards, with fresh rods, for making but a show and countenance of a saucy and irreverent behaviour towards' his children. ${ }^{29}$ But despite her father's diligence, his household seems to have afforded a great deal of fodder for the disapprobation of Mistress Hamblyn. To teach Mildmay to abhor the behaviour of the licentious, unfaithful married couple, Mistress Hamblyn composes and performs 'four or five verses' mocking them and 'wittily' condemning their debauchery. ${ }^{30}$ While the exercise clearly had a pedagogical aim, it verges on entertainment and seems a rather cheeky employment for a young girl. It cleverly transforms moral instruction into a childhood amusement.

Mildmay's childhood experiences illustrate the practical application of her educational theories and moral values. She recommends that children should read what she read as a child, and her memories provide supporting evidence for her general recommendations. She offers her own childhood as a kind of model upbringing. Using her parents and governess as examples, Mildmay holds up their attitudes and methods as guidelines for her daughter and grandchildren. Her goal is to provide prescriptive advice, and her childhood has to be viewed in light of her larger project of moral instruction. She represents herself as a child in order to help fashion other children in her image.

Although Mildmay provides a substantial account of her own childhood, she never writes about how she raised her own daughter. This fact may seem surprising given that she imagines her immediate audience as her daughter and her daughter's children. Yet her daughter's childhood 
remains completely absent. Linda Pollock has remarked on the oddity of this omission, suggesting that perhaps it can be explained by the fact that her daughter was an adult at the time the autobiography was written. ${ }^{31}$ Another possible explanation might be that setting oneself up as a paradigmatic student would feel different from setting oneself up as an ideal mother; the former allows Mildmay to credit her governess and parents for her achievements, whereas the latter might seem too much like self-praise. It is also unclear what purpose the description of her daughter's childhood would have played within the instructional framework of the memoirs. Having already described her own youth, perhaps describing her daughter's would have felt repetitive.

A woman who does talk about her daughter's girlhood is Anne Clifford. Like Grace Mildmay, Anne provides a memorial reconstruction of her own youth, but she does so as a prequel to a diary recounting her adult life. The first section recalls her life at court during the transitional period from Elizabeth's death to James's accession in 1603. The manuscript then jumps to the year 1616 as part of a more regular diary that offers a month-by-month account of her life between 1616 and 1619. ${ }^{32}$ It is in this second part that Anne introduces her two-year-old daughter Margaret, or 'the Child', into the equation. The now twentysix-year-old Anne begins using the text as a kind of datebook, keeping track of legal business as well as noting everyday details. In the first part, political events like James's coronation commingle with familial details about disputes between her parents and notes about her becoming sick from eating too many pear pies. When she starts keeping track of her adult life, she likewise alternates between mentioning her legal affairs and describing her daughter's latest fit of the ague. Mary Ellen Lamb has read this as part and parcel of Anne's establishment of her distinctly female voice, while Mihoko Suzuki has read the technique as part of Anne's construction of herself as central to her family's history. ${ }^{33}$ In terms of her representation of childhood, by bringing together the teenage girlhood of the mother with the much younger girlhood of her small child, Anne Clifford's diary beautifully illustrates the social and physical differences between aristocratic female children at different life stages.

Whereas Mildmay describes her upbringing as a prototype for the best way to raise children, Anne Clifford records her youthful memories and her daughter's childhood developments as part of a larger project 
of laying claim to her father's lands. ${ }^{34}$ The diary includes personal moments, but it does so in the service to Anne's dynastic ambitions. Technically, her father's vast northern estates in Westmoreland and Yorkshire had been entailed upon his daughter by a writ that stipulated they should be passed down to direct descendants regardless of sex. ${ }^{35}$ When her father died in 1605, however, he left the estate to his brother, Sir Francis Clifford, instead of to his fifteen-year-old daughter. With her mother's support, Lady Anne Clifford began a legal battle that would stretch on for nearly forty years. She eventually inherited the lands in 1643 when the death of her cousin Henry left her as the only remaining potential heir. In the meantime, she began documenting herself and her family's history as part of what she would come to call her 'Great Books', a genealogical collection of facts, dates and recollections of the Clifford family's past and present. Anne writes documents meant for her own use while living as well as for leaving behind her after death. ${ }^{36}$

Beginning with the funeral of Queen Elizabeth in 1603, the diary's description of the youthful Anne does not prefigure the woman she became, but the woman she should have become. Had her prospects panned out, she would have had a very different life. 'If Queen Elizabeth had lived,' Anne writes, 'she intended to prefer me to be of the Privy Chamber for at that time there was as much hope and expectations of me as of any other young lady whatsoever' (p. 42). ${ }^{37}$ The period of girlhood described in the diary consequently becomes a space of nostalgia. The acrimony between her parents notwithstanding, Anne recreates her thirteenth year as a happy and eventful one: a time of potential, before her father's death would plunge her into a thirty-eight-year legal battle to gain control of his lands.

As in Mildmay's autobiography, Anne figures girlhood as a time of intense observation. Hovering on the fringes of adult society, the young Anne watches the actions of the court with all the assiduousness of a young Mistress Hamblyn. But unlike Mildmay's governess, Anne studies adult behaviour for social rather than moral edification. Whereas Mistress Hamblyn teaches Mildmay to set herself apart and judge the people she surveys, Anne longs to join their community. Instead of seeking to evaluate, the girlish Anne searches for a way to insert herself into the historical events taking place around her. She expresses disappointment that her youth prevented her from playing a larger role in Queen Elizabeth's funeral, and reports having regretted being unable to join her mother and aunt in the procession of the queen's corpse toward Westminster. She was excluded, she says, 'by reason I was held too young' (p. 45). Prevented from participating in the ceremony, she had to content herself with being an eyewitness: 'I stood in the church 
at Westminster to see the solemnity performed' (p. 45). Anne as a child longs to play a more active role in the spectacle of adult life and eagerly anticipates the day when she will go from watching to being watched. In the meantime, she takes great pleasure in her participation as spectator, delighting in a trip to Windsor where she stands with the Princess Elizabeth in the shrine of the Great Hall 'to see the King and all the knights set at dinner' (p. 53).

Despite her sense of exclusion, Anne was remarkably integrated into courtly society. She attended Queen Elizabeth's funeral, she accompanied her mother and aunt on the new royal court's progress, and she helped to entertain the new Queen Anne when she stopped at Sir Henry Wallop's. Her inclusion in these activities as onlooker and occasional participant was part of her education. Anne's mother and aunt take care to introduce her to the ways of the court. They see to it that she learns who is who, with whom they are allies, and with whom they are rivals.

The focus of her courtly education is on the acquisition of social and political knowledge and, unlike Mildmay's autobiography, her diary remains strikingly free from any emphasis on being taught to be feminine or submissive. At no point does Anne recall being advised to be chaste, silent and obedient. Her mother does at one point punish her for riding ahead with a Mr Mene, but Anne does not reveal the reason her mother was angry, perhaps because she never evaluates her childhood behaviour in a moral context. The event becomes instead an opportunity to explain the formation of a deep friendship between Anne and her cousin Frances. For the young Anne, being alone and without company was a source of great anguish (reminiscent of Mildmay's desire always to be with her governess), and sleeping alone was a punishment. It was just such a punishment that her mother chose in this instance, and as Anne tells the story:

A little afore this time my mother and my aunt of Bath and my cousin Frances went to North Hall, my Mother being extreme angry with me for riding before with Mr. Menerell, where my mother in her anger commanded that I should lie in a chamber alone, which I could not endure, but my cousin Frances got the key of my chamber and lay with me which was the first time I loved her so very well. (p. 7)

A moralistic agenda like Mildmay's might use this anecdote to illustrate the danger that riding ahead with a man would pose to a young girl's reputation, or condemn the girls for not accepting a deserved rebuke. Anne shows no remorse. Her diary celebrates the act of minor disobedience for its initiation of an emotionally valuable relationship between two women. 
Indeed, the only aspect of Anne's childhood that makes it feel like a specifically female childhood is her firm location in a community of women. In addition to portraying girlhood as a time ripe with social potential, Anne's diary represents it as a time of close female friendships. She spends a great deal of time with her mother at the houses of her female relations, and she imitates the adult women's cultural practice of forging affective alliances. Sharing a bed with Frances and Mary Carey leads to a close friendship between Anne and the two other girls, all of them united by their positions on the cusp of adulthood. Together, they walk about the house and garden at Hampton Court, an activity that opens up space for them to play at participating more directly in court culture.

Given Anne's investment in tracing her own history back to the time of her youth, and her investment in providing a family history more generally, it is not surprising that when she turns to documenting the present, she also records the history of her daughter's physical and social development. Anne interests herself in the everyday material life of her daughter, from wearing new clothes to learning to walk. When Margaret cuts two new teeth in March 1617, giving her a total of eighteen, her mother duly notes it in her diary, and she does the same a few years later when the girl wears her first velvet coat on New Year's Day 1619 (p. 123, p. 155). The bulk of the references record childhood milestones like these; Margaret's girlhood appears in the diary as a series of 'firsts', from her first haircut to her first time sharing a bed with her parents.

Margaret's episodic appearances in the diary stem from the conditions of aristocratic childrearing. Like all children of the landed classes, Margaret had her own attendants and was not under the direct care of her mother. Her first appearance in the diary on 19 April 1616 is part of an entry in which Anne notes, 'This morning the Bishop of St. David's and my little Child were brought to speak to me' (p. 77). The phrasing of this statement makes no distinction between the visit of an adult guest and the visit of a daughter who lives in the house. A child like her daughter Margaret appears at this moment to be undifferentiated from adults in that she visits her mother just as any other person would. She has not been fully integrated into her parents' household, and a social and physical distance separates the mother and daughter. On 8 May 1617, for example, Anne writes that she spent the day doing needlework, 'the time being very tedious unto me as having neither comfort nor company only the Child' (p. 133). Differentiating between 'the Child' and 'company', Anne defines her daughter as outside of social existence. Anne's habit of referring to little Margaret as 'the Child' throughout the diary further 
suggests that she does not yet see her daughter as an individual or a person in her own right.

Not surprisingly, the child's perspective remains absent from the diary. Margaret's activities appear as events in her mother's life, rather than her own. Anne remembers, for example, that her husband went to London on 23 January 1613, which was 'the same day the Child put on her red baize coat' (p. 117). Margaret's scattered 'firsts' serve as memorial markers of other incidents. By intermingling references to Margaret's new clothes with details about the king's opposition to Anne's legal claims and notes about lending money to her sister, Anne provides herself with another way to keep track of what she has done and when. Along with knowing the date on which events occur, Anne also has enough personal details to remember the day in question. Jotting down when she gave Margaret's old clothes to her steward doubles as a record of what became of the garments and a way to remind herself that it was on the same day that she signed a bill to give Mr Askew seven pounds upon his return from Jerusalem (p. 119). This is not to say that Anne did not love her daughter. The diary certainly invests Margaret with an emotional presence, and it portrays Anne as preoccupied with her daughter's health. When the child suffered from the ague during the winter of 1616-17, her mother carefully records the frequency of her fits and the lengths of their duration, and she writes about personally attending to her daughter during them. She spent most of the day on 25 January 'going up and down to see the Child' during a fit that lasted six or seven hours (p. 117). Throughout the diary, Anne manifests an interest in her daughter's material life, what she wore and how she felt and whether they could be together, but her investment in her daughter's individual development does not prevent her from acknowledging the social dimensions of early modern parenting.

Children in the diary are first and foremost conduits for relationships between adults. Christenings are important in the lives of parents and godparents rather than the lives of infants. For Anne, the baptism of Sir Henry Vane's son offers an opportunity to further connections with a powerful family rather than an opportunity for the infant to undergo a spiritual initiation into the church; Vane named Lady Anne Clifford along with Lady Selby as the godmothers, and the names of these influential adults take precedence over the newborn. Likewise, when Anne goes to see Lady Somerset's child, she does so to please the proud mother and not for the child's sake. Even the incorporation of children into the economy of courtly gift-giving extended parental alliances. A courtesy to a child doubled as a courtesy to the parent. When Anne sends a servant with 'a little jewel of opal to Lady Trenchard's girl' in 
March 1617, she aims to please Lady Trenchard as much as the child (p. 123). Anne's daughter Margaret becomes the recipient of just such a gift on 4 February 1617, when Thomas Woodgate, who was in service to Richard Sackville, arrived from London and 'brought a squirrel to the Child' (p. 117). Woodgate's present thoughtfully provides the child with an amusement to help her through a time of sickness. It also elicits the gratitude of her mother, his master's wife.

The use of children to solidify adult friendships depended in some part upon the assumption that parents were invested in their children and loved them well enough to care about kindnesses to them. Caring about the daily human needs of children and seeing them as tools for negotiating relationships between adults were not necessarily mutually exclusive. Anne's affection for her daughter appears most strongly in the diary when her husband takes the child away from her. For all that the diary portrays her father Richard Sackville as fond of Margaret, it also reveals that he was not above using her as leverage in his legal negotiations with his wife. Sackville lived extravagantly and had sold a great deal of his lands to raise money to pay for clothing and gaming. He hoped to curry favour with the king and to receive ready money to support his profligate lifestyle in exchange for convincing his wife to drop her legal suit against her cousin. When Anne refused, her husband exercised his patriarchal rights and took away his wife's access to their daughter. On 3 May 1616, Sackville sent a letter insisting that Margaret be sent to him in London, a command that Anne describes as 'somewhat grievous' to her. She thought about refusing, but she writes, 'but when I considered that it would both make my Lord more angry with me and be worse for the Child, I resolved to let her go' (p. 79). She was to let the child go for some time afterwards, as she reports. Margaret left for London the next day, and five days later, on what Anne describes as 'a very grievous and sorrowful day', her husband sent word that his daughter was going to live at Horsely and would no longer be allowed to go to their house in Dorset (p. 20). Although Sackville's tactical move did not succeed in the long run, in the short run Anne seems to have made some compromises and promised to listen more to the arguments against pursuing her inheritance; on 19 June, Anne remarks that her lord had persuaded her to consent 'to his business' and assured her 'how good and kind a husband he would be' (p. 91). In exchange for her cooperation, he 'gave his faithful promise' to come after her to the north as soon as he could and 'the Child should come out of hand' so that she and her husband 'were never greater friends than at this time' (p. 93). Sackville made good on his promise, but Anne changed her mind about the business afterwards, noting in January 1617 that the queen had 
advised her against trusting the king. When she met with the king on the twentieth, she refused to give up Westmoreland, leaving James 'in a great chaff' (p. 113).

As Anne's experiences with her husband reveal, children could be loved individually and still used to create political and familial alliances. For Margaret, her role as a conduit for adult relationships eventually enables her to enter into the same world as her parents. From being a pawn in the negotiations between her parents, Margaret gradually begins to emerge in the diary as a larger player in the adult world as her parents introduce her to their aristocratic allies. The Sackvilles began the process of integrating Margaret more fully into their social lives by taking her to Northampton House on 23 December 1616. Anne, Richard and Margaret all went together to keep company with the group gathered around the Lord Treasurer, Thomas Howard, Earl of Suffolk. On this occasion, Anne records that the Lord Treasurer and 'all the company commended her [the child] and she went down into my Lady Walden's chamber where my cousin Anne saw her and kissed her but I stayed with my Lady Suffolk' (pp. 103-5). We can imagine that this is the kind of attention that Anne herself would pay to Lady Somerset's 'little child' when she visited her in the Tower in April 1619. Aristocratic visiting practices incorporated children as a way of sharing the interests of fellow parents. Margaret, in her mother's absence, has been petted and made much of by adults outside her family circle, and what we have in the diary is an adult's report of what the child must have told her. We have a second-hand glimpse here of Margaret's perspective and how much she enjoyed the kind treatment of the Lord Treasurer. As the thirteen-year-old Anne delighted in playing a part in the entertainments taking place around her, so too the very young Margaret seems to have found her brief sojourn on the adult stage exciting.

Anne does for her daughter what her mother and aunt did for her. She introduces Margaret at a young age to influential members of the court, and she brings the girl with her as the Sackvilles travel from household to household. Just as Anne's own girlhood remains strikingly free from concerns about inculcating feminine behaviour, her representation of her daughter's childhood places very little emphasis on the child's specifically female status. Although the diary employs the gendered pronoun 'she' to mark Margaret's biological sex, Anne always refers to her simply as 'the Child'. For all the mother's precision in documenting her daughter's illness, she expresses no concern about identifying her as a girl and reveals no anxiety about teaching her to be chaste and obedient. Margaret's name does not even appear in the diary until almost the end of the manuscript. 
The only hint of the daughter's initiation into a culture of femininity occurs in April 1617, when Anne identifies the twenty-eighth as the 'first time that the Child put on a pair of whalebone bodice' ( $\mathrm{p}$. 133). As Margaret grows up, Lady Anne slowly initiates her daughter into the fashionable dress of adult women, from the addition of laces to the wearing of velvet coats. Putting on a whalebone bodice brings Margaret's experience of clothing closer to that of an adult. Wearing this article of restrictive dress is part of the socialisation process, a feminine alternative to breeching, albeit one that remains far less publicly marked. The bodice proved to be a precursor of another crucial transition. Not long afterwards, Anne had her daughter leave off one of the signature aspects of children's dress: leading strings. Learning to walk required a change in costume. Anne writes, 'Upon the 1st I cut the Child's strings off from her coats and made her use to go about so as she had two or three falls at first but no hurt with them' (p. 133). Margaret here undergoes a significant step in the process of growing up in early modern England. Leading strings were attached to the back of a child's pinafore and used to help the child walk upright. The cutting of the strings signals Margaret's need to learn to walk by herself. The child thus begins an important transition from the costume of childhood to the costume of adulthood.

As Margaret grows older, she emerges as a slightly more distinct character as her parents begin to regard her as more of an individual and less of a generic child. On her fifth birthday, during which Sackville caused her health to be drunk throughout the house, her mother calls her daughter by the name Lady Margaret more often than 'the Child'. ${ }^{38}$ She also adds a note worrying about Margaret's linguistic development. Anne worries that strangers have a hard time understanding Margaret when she speaks, owing to a constant cold that winter, and while from a modern perspective Margaret's speech would seem to proceed from normal childhood difficulties of pronunciation and elocution, for Anne this was a real concern. The child who had appeared almost exclusively as a series of new outfits and fits of illness was starting to have specific traits. Accordingly, her parents commissioned their daughter's portrait, an indication of her increasing importance and individualisation. She was now on her way to being more closely integrated into courtly society and becoming the kind of active spectator that her mother was at thirteen.

Rather than being caught in a panoptical vision, Anne Clifford and her daughter Margaret seem to be in the audience with the world performing for them. The aristocratic adults in their lives seem to ignore these two children benevolently when necessary, allowing them to grow 
up outside the kind of Foucauldian gaze in which Mistress Hamblyn is so invested. Both Mildmay and Anne construct girlhood as a classspecific experience during which female children acquire the knowledge necessary to function in the world of the aristocracy, and this acquisition seems to require a certain amount of invisibility at particular moments. Even as female children become visible in aristocratic adult narratives and long for integration into the social world, their maturation depends upon watching.

III

As with aristocratic female children, the individual voices of girls from the labouring and merchant classes can be difficult to access because they only appear in a cursory way in sixteenth- and seventeenth-century texts. However, at least one autobiographical account has survived that in its transmission has preserved the residue of a merchant-class girl's writing presence. Inspired by her father's appearance in Holinshed's Chronicles, Rose Hickman Throckmorton decided to set down an account of her life for her children. With her own hand at the age of eighty-five, she wrote a brief autobiography, three seventeenth-century copies of which are extant in the British Library. ${ }^{39}$ The earliest of the manuscripts, entitled Certaine old stories recorded by an aged gentlewoman a littel before her death to be p[er]used by her children and posterity, is now bound with a partial copy made by Throckmorton's great-great-granddaughter Elisabeth Hickman as a childhood writing exercise in 1667 . These manuscripts link together two early modern women of different generations through a relation of family history that takes the great-great-grandmother's girlhood as its starting point and ends with the girlhood of her great-great-granddaughter. Although direct access to Elisabeth Hickman's voice remains elusive, her girlhood activities have left behind a material trace.

What Throckmorton's writing shares with Mildmay's and Anne Clifford's is the prominent place she accords English national history in her narrative of girlhood (and of her life more generally). In her recommended reading plan for fashioning children into Protestant adults, Mildmay makes knowledge of history a crucial component of children's education. Along with the Bible, John Foxe's Acts and Monuments, statutes and law, and philosophy, Mildmay prescribes reading in the English chronicles. Her dictum that children of both sexes should read history is particularly provocative because in other contexts reading history was constructed as a masculine pursuit. Charles Herle, as quoted by William 
London in 1658, described the study of history as a way to train 'minds to manlike actions' on the way to being weaned from 'childish effeminacy'. ${ }^{40}$ However, if reading history was a gendered activity, it was one in which educated women definitely participated, as we can see clearly in Anne Clifford's diary and Throckmorton's reminiscences. Anne frequently mentions reading in 'the Chronicles', and Throckmorton begins her own narrative by quoting them. Anne Clifford and Rose Throckmorton share a common goal of reading, writing and participating in history, and both set up political, religious and social events as important influences on their experiences of growing up female.

As a Protestant woman of the merchant class who lived through the reigns of five monarchs - Henry VIII, Edward VI, Mary Tudor, Elizabeth I and James I - Throckmorton's manuscript provides an invaluable lens into the lives of Protestant merchants during the turbulent period of the English Reformation. Rose Throckmorton was the daughter of William Lock, a London mercer who was later in the service of Henry VIII. Lock secured his place in English history when he agreed to travel to Dunkirk to remove Pope Clement VII's proclamation of Henry's excommunication. His actions secured him a brief mention in Holinshed's chronicles, the citation with which Throckmorton begins her narrative. She uses his entry into the history books as her entry into writing, amplifying the account by recording her personal memories.

Paired with her great-great-granddaughter's copy, Throckmorton's manuscript is a material testament to the way that unpublished women's writing could provide a literary legacy for other women. Elisabeth Hickman signed and dated her copy of her great-great-grandmother's autobiography on several pages, and the rules on the page are still visible. The handwriting is clearly that of a novice, and the text is unfinished. Hickman stops copying at the point in the original text where Throckmorton's first husband and brother were imprisoned by Mary Tudor. The goal of the task seems to have been for the young Elisabeth to practise her handwriting, and it is the kind of exercise that Mildmay reports being assigned by Mistress Hamblyn to prevent her from being idle. The young Elisabeth may have moved on to another exercise or become tired. One more page has been copied out in an adult's handwriting with different ink, but the hand remains unidentified. Although relatively ephemeral, the surviving notebook with its multiple signatures suggests that Elisabeth was claiming ownership over the physical page even if the substance belonged to her great-great-grandmother, an action that allowed her, even as a child, to write herself into her family's history.

All of the examples of life writing in this chapter share a conviction that political and social events play significant roles in girls' lives; they 
also share a conviction that girls play significant roles in political and social events. The girlish selves of these women writers observed the world around them and found a way to respond to their culture, and the culture could not help but respond in turn. These women wrote and were written about, however, not as girls per se, but as ex-girls. For these women, their past childhood selves become like Holinshed's Chronicles or Foxe's Booke of Martyrs, texts from the past to be reshaped into their present narratives.

I began by saying that we do not have unfettered access to early modern girls' and women's lives, and it was undoubtedly clear that I said that with a sense of loss. For all that it has been pleasurable to find presence where I had initially seen an absence, it can be disappointing to recognise that these narratives are opaque and non-transcendent. I find comfort in realising that if we can't speak in an unmediated way with the dead, neither can we speak in an unmediated way with the living. If, as Judith Butler argues, "The "I" has no story of its own that is not also the story of a relation - or a set of relations - to a set of norms', ${ }^{41}$ that is as true for my own account of myself as for early modern girls and women.

\section{Notes}

1. Quoted in George C. Williamson, Lady Anne Clifford, Countess of Dorset, Pembroke, and Montgomery, 1590-1676: Her Life, Letters, and Work (Kendal: Titus Wilson and Son, 1922), p. xxii, image reproduced in Plate 43. The physical letter can be viewed on the Skipton Castle website at <http://www.skiptoncastle.co.uk/uploads/lady-anne-letter.jpg> (accessed 4 July 2012).

2. 'Lady Anne's Needlework: English Retreat and Scottish Tour 15th-30th June, 2012', <http://www.crewelwork.com/> (accessed 1 January 2012).

3. For a discussion of the desire for the past and its frustrations, see Stephen Greenblatt, Shakespeare Negotiations (Berkeley: University of California Press, 1988), p. 1.

4. For discussions of the limitations of reading women's non-fiction as a transparent lens into women's lives, see Jay Mechling, 'Advice to Historians on Advice to Mothers', Journal of Social History 9 (1975), pp. 44-63, and Sidonie Smith and Julia Watson, 'Introduction', in Women, Autobiography, Theory: A Reader (Madison: University of Wisconsin Press, 1998), pp. 21-7.

5. Rachel Fane, Notebooks, Centre for Kentish Studies, MS U269 F38/1-4.

6. Robert C. Evans, Introduction to 'Verses made by a Maid under 14 (c. 1657-58)', in Helen Ostovich and Elizabeth Sauer (eds), Reading Early Modern Women: An Anthology of Texts in Manuscript and Print, 15501700 (New York: Routledge, 2004), p. 83. 
7. 'Verses made by a Maid under 14', A3, lines 25-6.

8. Kate Chedgzoy, Women's Writing in the British Atlantic World: Memory, Place, and History, 1500-1700 (Cambridge: Cambridge University Press, 2007), p. 32.

9. Michael Witmore, Pretty Creatures: Children and Fiction in the English Renaissance (Ithaca: Cornell University Press, 2007).

10. See especially Rita Felski's work on women and confession in Beyond Feminist Aesthetics: Feminist Literature and Social Change (Cambridge, MA: Harvard University Press, 1989), pp. 86-121.

11. My approach diverges from Sharon Cadman Seelig in that I am not so much concerned with 'the autobiographical impulse' as with the way narratives about early modern girlhoods tend to be structured not as self-writing but as writing about a self that is no longer or never was the self. See Sharon Cadman Seelig, Autobiography and Gender in Early Modern Literature: Reading Women's Lives, 1600-1800 (Cambridge: Cambridge University Press, 2006), p. 1.

12. Margaret Clifford, Letter, quoted in George C. Williamson, George Clifford, 3rd Earl of Cumberland (1558-1605) (Cambridge: Cambridge University Press, 1920), p. 285.

13. James Daybell, Women Letter Writers in Tudor England (Oxford: Oxford University Press, 2006), p. 171.

14. Margaret Clifford, Letter, quoted in Williamson, George Clifford, p. 287.

15. Ibid. pp. 286-7.

16. Ibid. p. 285.

17. Ibid. p. 285.

18. Margaret Clifford's biographical information is primarily available from sources about her husband, like Williamson's book, or work on her more famous daughter. For details on her relationship with Anne, see Richard T. Spence, Lady Anne Clifford (Stroud: Sutton, 1997), as well as Williamson's biography.

19. Margaret Clifford, Letter, quoted in Williamson, George Clifford, p. 287.

20. Lady Grace Mildmay, 'Autobiography', in Linda Pollock (ed.), With Faith and Physic: The Life of a Tudor Gentlewoman: Lady Grace Mildmay, 1552-1620 (London: Collins \& Brown, 1993). Most of the work on Mildmay has been on her life writing, but for work on her religious writings, see Kate Narveson, 'Authority, Scripture, and Typography in Lady Grace Mildmay's Manuscript Meditations', in Micheline White (ed.), English Women, Religion, and Textual Production, 1500-1625 (Aldershot: Ashgate, 2011), pp. 167-84.

21. Grace Mildmay, née Sharington, and her husband Anthony Mildmay were married at an unusually young age. Mildmay was fifteen, and her husband Anthony was twenty, and according to Mildmay's account, his father pressured him into the match. Mildmay makes no mention of what her feelings about the marriage were, but she indicates that Anthony was far more interested in travelling and adventure than in settling down to domestic arrangements. In fact, their marriage was even more unusual in that the couple spent much of their first twenty years apart, with Anthony 
travelling on the Continent. They did eventually have one child, a daughter born a good fifteen years after they were wedded. Also strange about the match was that no financial arrangements were officially settled, a fact that would produce problems for the Mildmays later when it came to both Lady Mildmay's and her husband's inheritances. For details, see Pollock, 'Family Affairs', in With Faith and Physic, pp. 4-22.

22. Lady Grace Mildmay, 'Autobiography', p. 26.

23. Ibid. p. 26.

24. Ibid. p. 26.

25. Ibid. pp. 25-6.

26. Ibid. p. 26.

27. Ibid. pp. 25-6.

28. Ibid. pp. 26-7.

29. Ibid. pp. 27-8.

30. Ibid. p. 27.

31. As Pollock points out, 'it cannot be argued that Lady Mildmay was uninterested in children' because she states elsewhere that she had been disappointed when she remained childless during her first fifteen years of marriage. See Pollock, With Faith and Physic, p. 11.

32. For an explanation of the various manuscripts of Anne Clifford's diary and its relationship to her other forms of life writing, including her Great Books, see Paul Salzman, Reading Early Modern Women's Writing (Oxford: Oxford University Press, 2006), pp. 95-101.

33. Mary Ellen Lamb, 'The Agency of the Split Subject: Lady Anne Clifford and the Uses of Reading', English Literary Renaissance 22 (1992), pp. 347-68, and Mihoko Suzuki, 'Anne Clifford and the Gendering of History', Clio 30 (2001), pp. 195-230.

34. See Barbara Kiefer Lewalski, 'Rewriting Patriarchy and Patronage: Margaret Clifford, Anne Clifford, and Aemilia Lanyer', Yearbook of English Studies 21 (1991), pp. 87-106, and her chapter on Anne in Writing Women in Jacobean England (Cambridge: Cambridge University Press, 1993).

35. For a detailed account of the entailment, see Williamson, Lady Anne Clifford, pp. 489-507.

36. For an astute analysis of her Great Books as well as the history of Anne Clifford's scholarly reception, see Salzman, Reading Early Modern Women's Writing, pp. 90-108.

37. All quotations from Anne Clifford's diary come from The Memoir of 1603 and Diary of 1616-19, ed. Katherine Acheson (Peterborough, Ontario: Broadview, 2007).

38. See Acheson, p. 77, n. 38.

39. For an extended account of the differences between the three and an analysis of Throckmorton's construction of Protestant history, see my article 'The Exile of Rose Hickman Throckmorton', Reformation 15 (2010), pp. 99-114. The manuscripts are British Library Additional MS 43827 A, British Library Additional MS 43827 B, and British Library Additional MS 45027. My references are to the manuscripts, but Maria Dowling and Joy Shakespeare offer an accurate transcription to BL Add MS 43827 A in 'Religion and Politics in Mid-Tudor England through the Eyes of an English 
Protestant Woman: The Recollections of Rose Hickman', Bulletin of the Institute of Historical Research 55 (1982), pp. 94-102.

40. Charles Herle, quoted in William London, Catalogue of the Most Vendible Books in England (London, 1657), sig. G1r.

41. Judith Butler, Giving an Account of Oneself (New York: Fordham University Press, 2005), p. 8. 


\title{
Epilogue: Mass-Produced Languages and the End of Touristic Choices
}

\author{
'Dreamwood' \\ In the old, scratched, cheap wood of the typing stand \\ there is a landscape, veined, which only a child can see \\ or the child's older self, \\ a woman dreaming when she should be typing \\ the last report of the day. If this were a map, \\ she thinks, a map laid down to memorize \\ because she might be walking it, it shows \\ ridge upon ridge fading into hazed desert, \\ here and there a sign of aquifers \\ and one possible watering-hole, If this were a map \\ it would be the map of the last age of her life, \\ not a map of choices but a map of variations \\ on the one great choice. It would be the map by which \\ she could see the end of touristic choices, \\ of distances blued and purpled by romance, \\ by which she would recognize that poetry \\ isn't revolution but a way of knowing \\ why it must come. If this cheap, massproduced \\ wooden stand from the Brooklyn Union Gas Co., \\ massproduced yet durable, being here now, \\ is what it is yet a dream-map \\ so obdurate, so plain, \\ she thinks, the material and the dream can join \\ and that is the poem and that is the late report.
}

Adrienne Rich, from Time's Power (1989)

I would like to think that words like 'man' and 'woman', 'girl' and 'boy', 'masculine' and 'feminine' are like Adrienne Rich's mass-produced typing stand, products of a communal linguistic project beyond our control, marked with the traces of a history at once personal and impersonal, cheap and yet durable. We use these words because otherwise we wouldn't have anything else on which to set our typewriters, and in using them we scratch them and leave behind our own traces, our own 
speech acts, our own potential to be cited as an example of how the use of a word in language transforms its meaning.

I am completing this book at a moment when it feels imperative to assert the worth of scholarship that puts girls and women, not just gender or kinship formations, at the centre of its investigational questions. I feel that girls offer a way to keep women at the forefront of our discussions even as we remain cognisant that there is nothing essential about either 'girls' or 'women'. Early modern speakers and writers felt the need for a more multivalent vocabulary with which to negotiate these issues, and we as twenty-first-century feminist literary critics need access to a vocabulary that is at least as rich as theirs was. 


\title{
Bibliography
}

\author{
Manuscripts
}

Fane, Rachel, Notebooks, Centre for Kentish Studies, MS U269 F38/1-4.

Isham, Elizabeth, Book of Remembrance, MS RTC01 no. 62, Robert H. Taylor Collection, Manuscripts Division, Department of Rare Books and Special Collections, Harvey S. Firestone Library, Princeton University; transcription available at <http://www2.warwick.ac.uk/fac/arts/ren/projects/isham> (accessed 27 June 2012).

Lumley, Jane (trans.), Iphigenia at Aulis, British Library Royal MS 15.A.9.

Pulter, Hester, 'Alithea's Pearl', in Poems breathed forth by the nobel Hadassas, and The Unfortunate Florinda, University of Leeds Library, Brotherton Collection, MS Lt q 32, 92-7.

Throckmorton, Rose Hickman, Certain Old Storyes Recorded by an Aged Gentlewoman to be Perused by her Children and Posterity, British Library Additional MS 45027.

Throckmorton, Rose Hickman, Certaine old stories recorded by an aged gentlewoman a littel before her death to be p[er] used by her children and posterity, British Library Additional MS 43827 A and B.

\section{Primary Sources}

A Larum for London, ed. W. W. Greg, Malone Society Reprints (Oxford: Oxford University Press, [1602] 1913).

Alphonsus, Emperor of Germany (London, 1654).

Anger, Jane, Jane Anger Her Protection for Women (London, 1589).

Ascham, Roger, The Scholemaster (London, 1570).

B., T., The Country Girle (London, 1647).

Bacon, Francis, The Works of Francis Bacon (Philadelphia: Carey and Hart, 1842).

Beaumont, John, and John Fletcher, The Chances, in Fredson Bowers (ed.), The Dramatic Works in the Beaumont and Fletcher Canon, Vol. IV (Cambridge: Cambridge University Press, 1979), pp. 541-645.

Becon, Thomas, A New Catechisme sette forth in Dialoge wise in familiare talke between the father and son, in The Catechism of Thomas Becon, ed. 
John Ayre, Parker Society Reprint (Cambridge: Cambridge University Press, [1564] 1968).

Bestney, Thomas, Thesaurus Linguae Romanae \& Britannicae (London, 1587).

Birck, Sixtus, Sapientia Solomonis, Acted Before the Queen by the Boys of Westminster School, ed. Elizabeth Rogers Payne (New Haven: Yale University Press, 1938).

Book of Common Prayer (London, 1559).

Brome, Richard, The Northern Lass (London, 1632).

Brome, Richard, The Queen and Concubine, in Five New Plays (London, 1659).

Brome, Stephen, 'To his ingenious Brother M RICH. BROME', in Richard Brome, The Northern Lass (London, 1632), sig. A3v.

Bullokar, John, An English Expositor: teaching the interpretation of the hardest words in our language (London, 1616).

Chapman, George, The Blinde Begger of Alexandria (London, 1598).

Chettle, Henry, Thomas Dekker and William Haughton, The Pleasant Comodie of Patient Grissill, Tudor Facsimile Texts, ed. John Farmer (New York: AMS Press, [1603] 1970).

Cleaver, Robert, A Godly Form of Household Government (London, 1598).

Clifford, Anne, The Memoir of 1603 and Diary of 1616-19, ed. Katherine Acheson (Peterborough, Ontario: Broadview, 2007).

Clifford, Margaret, Letter, quoted in George C. Williamson, George Clifford, 3rd Earl of Cumberland (1558-1605) (Cambridge: Cambridge University Press, 1920), pp. 285-7.

Comenius, John Amos, Orbis Sensualium Pictus ... Visible World. Or, A picture and nomenclature of all the chief things that are in the world; and of mens employments therein, trans. Charles Hoole (London, 1659).

'Consistory Court of London, Correction Book, fols. 19-20', in S. P. Cerasano and Marion Wynn-Davies (eds), Renaissance Drama by Women: Texts and Documents (London: Routledge, 1996), p. 172.

Cooper, Thomas, Bibliotheca Eliotae (London, 1548).

Culpeper, Nicholas, A Directory for Midwives (London, 1651).

Dekker, Thomas, Wonderfull Yeare (London, 1603).

Documents of the Baptismal Liturgy, ed. E. C. Whitaker (Collegeville, MN: Liturgical Press, 1960).

Duncon, John, The Retvrnes of Spiritual Comfort and Grief in a Devout Soul (London, 1649).

Edgar, Thomas, The Lawes Resolutions of Women's Rights (London, 1632).

Elyot, Thomas, Bibliotheca Eliotae (London, 1542).

Fletcher, John, A Critical Edition of John Fletcher's The Humorous Lieutenant, ed. Phillip Morrow Oxley (New York: Garland, 1987).

Florio, John, A Worlde of Wordes, or Most Copious, Dictionarie in Italian and English (London, 1598).

Gascoigne, George, The Adventures of Master F. J., in Paul Salzman (ed.), An Anthology of Elizabethan Prose Fiction (Oxford: Oxford University Press, 1987).

Gascoigne, George, The Adventures of Master F. J., in A Hundreth Sundrie Flowres (London, 1573).

Gascoigne, George, The Posies (London, 1575).

Gosson, Stephen, Plays Confuted in Five Acts, in S. P. Cerasano and Marion 
Wynne-Davies (eds), Renaissance Drama by Women: Texts and Documents (New York: Routledge, 1996), p. 162.

Greene, Robert, Pandosto, Appendix B, in The Winter's Tale, ed. Stephen Orgel (Oxford: Oxford University Press, 1996), pp. 234-74.

Guillemeau, Jacques, Child-birth, or The Happy Deliverie of Women (London, 1612).

Haec Vir, or, The Womanish Man (London, 1620).

Harington, John, The Most Elegant and Witty Epigrams (London, 1618).

Herrick, Robert, Hesperides, or, The Works Both Humane and Divine (London, 1648).

Heywood, John, Iohn Heywoodes woorkes: Three hundred Epigrammes vpon three hundred prouerbes (London, 1562).

Heywood, Thomas, The Fair Maid of the West, Parts I and II, ed. Robert K. Turner, Jr. (London: Edward Arnold, [1631] 1968).

Heywood, Thomas, A Pleasant Comedy, called a Mayden-head Well Lost (London, 1634).

Hic Mulier, or, the Man-Woman (London, 1620).

Hughes, Thomas, The Misfortunes of Arthur, in Certaine deu[is]es and shewes presented to her Maiestie by the gentlemen of Grayes-Inne at her Highnesse court in Greenewich, the twenty eighth day of Februarie in the thirtieth yeare of her Maiesties most happy raigne (London, 1588).

An humble request to the honourable charitable gentry of St. Pauls CoventGarden, with other great and noble persons, ladies, gentry, and well-wishers to the numerous poor children in St. Martins, St. Giles's, and St. Clements Danes, in the county of Middlesex (London, 1682).

Jacob and Esau (London, 1568).

Johnson, Samuel, Dictionary of the English Language (London, 1786).

Langland, William, The Vision of Piers Plowman, ed. A. V. C. Schmidt, 2nd edn (London: Everyman, 1995).

London, William, Catalogue of the Most Vendible Books in England (London, 1657).

Markham, Gervase, Cheape and Good Husbandry (London, 1653).

Marlowe, Christopher, Tamburlaine the Great, Part One, in The Complete Plays, ed. Frank Romany and Robert Lindsey (London: Penguin, 2003).

Memorials of Stepney Parish, ed. G. W. Hill and W. H. Frere (Guildford: Billing \& Sons, 1890).

Middleton, Thomas, A Chaste Maid in Cheapside, ed. Alan Brissenden (London: A \& C Black, [1630] 2002).

Middleton, Thomas, and Thomas Dekker, The Roaring Girl, ed. Paul Mulholland (Manchester: Manchester University Press, [1611] 1987).

Middleton, Thomas, and William Rowley, A Fair Quarrel, ed. R. V. Holdsworth (London: Ernest Benn Limited, [1617] 1974).

Middleton, Thomas, and John Webster, Anything for a Quiet Life (London, 1662).

Mildmay, Lady Grace, 'Autobiography', in Linda Pollock (ed.), With Faith and Physic: The Life of a Tudor Gentlewoman: Lady Grace Mildmay, 1552-1620 (London: Collins \& Brown, 1993).

Mulcaster, Richard, Positions Concerning the Training Up of Children, ed. William Barker (Toronto: University of Toronto Press, [1581] 1994). 
Munda, Constantia, The Worming of a Mad Dog (London, 1617).

Naogeorgus, Thomas, The Popish Kingdome, trans. Barnabe Googe (London, 1570).

A New English Dictionary Shewing the Etymological Derivation of the English Tongue (London, 1691).

Nice Wanton, in The Tudor Interludes Nice Wanton and Impatient Poverty, ed. Leonard Tennenhouse (New York: Garland, [1560] 1984), pp. 65-125.

The Norton Shakespeare, ed. Stephen Greenblatt, Walter Cohen, Jean E. Howard and Katharine Eisaman Maus (New York: Norton, 1997).

Palsgrave, John, Lesclarcissement de la langue francoyse (London, 1530).

Paré, Ambroise, The Workes of that famous Chirurgion Ambroise Parey, trans. Thomas Johnson (London, 1634).

Phillip, John, The Comodye of Pacient and Meeke Grissill, Malone Society Reprints (Chiswick: Charles Whittingham \& Co, [1569] 1909).

Raynald, Thomas, The Byrth of Mankynde, or the Womans Book (London, 1552).

Rösslin, Eucharius, The Byrth of Mankynde, trans. Richard Jonas (London, 1540).

Ruggle, George, Ignoramus Comoedia coram Regia Maiestate Iacobi Regis Angliae (London, 1630).

S., J., England's Merry Jester: Or, Court, City, and Country Jests, New, and Suitable to the Humours of the Times (London, 1693).

'The Sarum Rite', in E. C. Whitaker (ed.), Documents of the Baptismal Liturgy, trans. A. J. Collins (Collegeville, MN: Liturgical Press, 1960).

The Second Shepherds' Play, in Everyman and Other Miracle and Morality Plays, ed. Candace Ward (New York: Dover, 1995), pp. 12-35.

Shakespeare, William, The Winter's Tale, ed. Stephen Orgel (Oxford: Oxford University Press, 1996).

Shakespeare, William, The Winter's Tale, ed. J. H. P. Pafford (London: Thomas Nelson and Sons, 1999).

Sharp, Jane, The Midwives Book, or the Whole Art of Midwifry Discovered, ed. Elaine Hobby (Oxford: Oxford University Press, [1671] 1999).

Sowernam, Esther, Esther Hath Hang'd Haman (London, 1617).

Speght, Rachel, A Movzell for Melastomvs (London, 1617).

Thomas, William, Principal Rules of the Italian Grammar (London, 1550).

Tom a Lincoln, Malone Society Reprints (Oxford: Oxford University Press, 1992).

Torriano, Giovanni, Vocabulario Italiano e Inglese (London, 1659).

The Tragedie of Nero (London, 1624).

'Verses made by a Maid under 14 (c. 1657-58)', in Helen Ostovich and Elizabeth Sauer (eds), Reading Early Modern Women: An Anthology of Texts in Manuscript and Print, 1550-1700 (New York: Routledge, 2004), p. 83.

Vives, Juan Luis, De institutione foeminae Christianae, ed. Charles Fantazzi and Contantinus Matheeussen (Leiden: Brill, [1524] 1996).

Vives, Juan Luis, The Instruction of a Christen Woman, ed. Virginia Walcott Beauchamp, trans. Richard Hyrde (Urbana: University of Illinois Press, [1529] 2002).

A Warning for Fair Women: A Critical Edition, ed. Charles Dale Cannon (The Hague: Mouton, 1975). 
The Weakest Goeth to the Wall (London, 1600).

Webster, John, and William Rowley, The Thracian Wonder (London, 1661).

White, Robert, Cupid's Banishment, in S. P. Cerasano and Marion Wynne-

Davies (eds), Renaissance Drama by Women: Texts and Documents (New York: Routledge, 1996), pp. 76-89.

Whitney, Isabella, 'The Maner of her Wyll', in A Sweet Nosegay, Or Pleasant Posy: Containing a Hundred and Ten Philosophical Flowers (London, 1573).

Wilson, Robert, The Coblers Prophesie (London, 1594).

\section{Secondary Sources}

Adelman, Janet, 'Making Defect Perfection: Shakespeare and the One-Sex Model', in Viviana Comensoli and Anne Russell (eds), Enacting Gender on the English Renaissance Stage (Urbana: University of Illinois Press, 1999), pp. 23-52.

Althusser, Louis, 'Ideology and Ideological State Apparatuses', trans. Ben Brewster, in Lenin and Philosophy and Other Essays (New York: Monthly Review, 1972), pp. 127-93.

Amtower, Laurel, and Dorothea Kehler (eds), The Single Woman in Medieval and Early Modern England: Her Life and Representation (Tempe: Arizona Center for Medieval and Renaissance Studies, 2003).

Anderson, M. D., Drama and Imagery in English Medieval Churches (Cambridge: Cambridge University Press, 1968).

Ariès, Philippe, Centuries of Childhood, trans. Robert Baldick (New York: Vintage, 1962).

Bartolovich, Crystal, “'Optimism of the Will”: Isabella Whitney and Utopia', Journal of Medieval and Early Modern Studies 39 (2009), pp. 407-32.

Baston, Jane, 'Rehabilitating Moll's Subversion in The Roaring Girl', Studies in English Literature 37 (1997), pp. 317-35.

Bedaux, Jan Baptist, and Rudi Ekkart (eds), Pride and Joy: Children's Portraits in the Netherlands 1500-1700 (Amsterdam: Ludion Press, 2000).

Belsey, Catherine, 'Disrupting Sexual Difference: Meaning and Gender in the Comedies', in John Drakakis (ed.), Alternative Shakespeares (London: Methuen, 1985), pp. 166-90.

Belsey, Catherine, 'Little Princes: Shakespeare's Royal Children', in Kate Chedgzoy, Susanne Greenhalgh and Robert Shaughnessy (eds), Shakespeare and Childhood (Cambridge: Cambridge University Press, 2007), pp. 32-48.

Belsey, Catherine, 'Shakespeare's Little Boys: Theatrical Apprenticeship and the Construction of Childhood', in Bryan Reynolds and William N. West (eds), Rematerializing Shakespeare: Authority and Representation on the Early Modern English Stage (Basingstoke: Palgrave, 2005), pp. 53-72.

Ben-Amos, Ilana Krausman, Adolescence and Youth in Early Modern England (New Haven: Yale University Press, 1994).

Ben-Tsur, Dalia, 'Early Ramifications of Theatrical Iconoclasm: The Conversion of Catholic Biblical Plays into Protestant Drama', Partial Answers: Journal of Literature and the History of Ideas 3 (2005), pp. 43-56.

Bennett, Judith M., and Amy M. Froide (eds), Singlewomen in the European Past, 1250-1800 (Philadelphia: University of Pennsylvania Press, 1999). 
Bentley, Gerald Eades, The Jacobean and Caroline Stage: Dramatic Companies and Players, 7 vols (Oxford: Clarendon, 1941).

Bergeron, David, Shakespeare's Romances and the Royal Family (Lawrence: University of Kansas Press, 1985).

Bevington, David, From Mankind to Marlowe: Growth of Structure in the Popular Drama of Tudor England (Cambridge, MA: Harvard University Press, 1962).

Bicks, Caroline, 'Producing Girls in Mary Ward's Convent Schools', in Naomi Miller and Naomi Yavneh (eds), Gender and Early Modern Constructions of Childhood (Aldershot: Ashgate, 2011), pp. 139-53.

Bliss, Lee, 'The Renaissance Griselda: A Woman for All Seasons', Viator: Medieval and Renaissance Studies 23 (1992), pp. 301-43.

Bornstein, Kate, Gender Outlaw: On Men, Women, and the Rest of Us (New York: Routledge, 1994).

Bowden, Caroline, 'The Notebooks of Rachel Fane: Education for Authorship', in Victoria E. Burke and Jonathan Gibson (eds), Early Modern Women's Manuscript Writing: Selected Papers from the Trinity/Trent Colloquium (Aldershot: Ashgate, 2004), pp. 157-80.

Bradner, Leicester, 'A Test for Udall's Authorship', Modern Language Notes 42 (1927), pp. 378-80.

Brown, Pamela Allen, Better a Shrew than a Sheep: Women, Drama, and the Culture of Jest in Early Modern England (Ithaca: Cornell University Press, 2003).

Buck, Anne, Clothes and the Child: A Handbook of Children's Dress in England 1500-1900 (New York: Holmes \& Meier, 1996).

Bushnell, Rebecca, A Culture of Teaching: Early Modern Humanism in Theory and Practice (Ithaca: Cornell University Press, 1996).

Butler, Judith, Gender Trouble: Feminism and the Subversion of Identity (New York: Routledge, 1990).

Butler, Judith, Giving an Account of Oneself (New York: Fordham University Press, 2005).

Butler, Judith, Undoing Gender (New York: Routledge, 2004).

Bynum, Theodora, Historical Linguistics (Cambridge: Cambridge University Press, 1977).

Callahan, Dympna, Shakespeare Without Women: Representing Gender and Race on the Renaissance Stage (London: Routledge, 2000).

Calvert, Karin, Children in the House: The Material Culture of Early Childhood, 1600-1900 (Boston: Northeastern University Press, 1992).

Cavell, Stanley, 'Excursus on Wittgenstein's Vision of Language', in The Claim of Reason (Oxford: Oxford University Press, 1999), pp. 168-90.

Chedgzoy, Kate, 'Introduction: "What, are they children?", in Chedgzoy, Susanne Greenhalgh and Robert Shaughnessy (eds), Shakespeare and Childhood (Cambridge: Cambridge University Press, 2007), pp. 15-31.

Chedgzoy, Kate, Women's Writing in the British Atlantic World: Memory, Place, and History, 1500-1700 (Cambridge: Cambridge University Press, 2007).

Cheney, Patrick, 'Moll Cutpurse as Hermaphrodite in Dekker and Middleton's The Roaring Girl', Renaissance and Reformation 7 (1983), pp. 120-34. 
Clark, Alice, Working Life of Women in the Seventeenth Century (London: Routledge, [1919] 1982).

Cole, Maijja Jansson, 'A New Account of the Burning of the Globe', Shakespeare Quarterly 32 (1981), p. 352.

Comensoli, Viviana, 'Play-making, Domestic Conduct, and the Multiple Plot in The Roaring Girl', Studies in English Literature 37 (1997), pp. 249-66.

Cowden Clarke, Mary, The Girlhood of Shakespeare's Heroines; in a Series of Tales (New York: G. P. Putnam's Sons, 1874).

Cowden Clarke, Mary, 'Shakespeare as the Girl's Friend', in Ann Thompson and Sasha Roberts (eds), Women Reading Shakespeare, 1660-1900 (Manchester: Manchester University Press, 1997), pp. 101-3.

Cressy, David, Birth, Marriage, and Death: Ritual, Religion, and the LifeCycle in Tudor and Stuart England (Oxford: Oxford University Press, 1997).

Crupi, Charles, 'Subduing Bess Bridges: Ideological Shift in the Two Parts of The Fair Maid of the West', Cahiers Elisabéthains 54 (1998), pp. 75-87.

Cunningham, Hugh, Children and Childhood in Western Society since 1500 (New York: Longman, 1995).

Curran, John E., 'Jacob and Esau and the Iconoclasm of Merit', Studies in English Literature, 1500-1900 49 (2009), pp. 285-309.

Curzan, Anne, Gender Shifts in the History of English (Cambridge: Cambridge University Press, 2003).

Daybell, James, Women Letter Writers in Tudor England (Oxford: Oxford University Press, 2006).

Desmet, Christy, 'Character Criticism', in Stanley Wells and Lena Cowen Orlen (eds), Shakespeare: An Oxford Guide (Oxford: Oxford University Press, 2003), pp. 351-62.

Dessen, Alan C., Elizabethan Stage Conventions and Modern Interpreters (Cambridge: Cambridge University Press, 1984).

Dessen, Alan C., Recovering Shakespeare's Theatrical Vocabulary (Cambridge: Cambridge University Press, 1995).

Donawerth, Jane, 'Women's Poetry and the Tudor-Stuart System of Gift Exchange', in Donawerth, Linda Dove and Karen Nelson (eds), Women, Writing, and the Reproduction of Culture in Tudor and Stuart Britain (Syracuse: Syracuse University Press, 2000), pp. 3-18.

Dowling, Maria, and Joy Shakespeare, 'Religion and Politics in Mid-Tudor England through the Eyes of an English Protestant Woman: The Recollections of Rose Hickman', Bulletin of the Institute of Historical Research 55 (1982), pp. 94-102.

Dunworth, Felicity, “A Bosom Burnt Up With Desires”: The Trials of Patient Griselda on the Elizabethan Stage', Paragraph 21 (1993), pp. 330-53.

Dusinberre, Juliet, 'Boys Becoming Women in Shakespeare's Plays', Shakespeare Studies 36 (1998), pp. 1-28.

Eastwood, Adrienne L., 'Controversy and the Single Woman in The Maid's Tragedy and The Roaring Girl', The Rocky Mountain Review of Language and Literature 58 (2004), pp. 7-27.

Eller, Ernest M., 'Introduction', in John Amos Comenius, School of Infancy (Chapel Hill: University of North Carolina Press, 1956).

Ephraim, Michelle Karen, 'Jewish Matriarchs and the Staging of Elizabeth I in 
The History of Jacob and Esau', Studies in English Literature, 1500-1900 43 (2003), pp. 301-21.

Erickson, Amy Louise, Women and Property in Early Modern England (New York: Routledge, 1993).

Eriksen, Roy, 'The Mimesis of Change: Gascoigne's Adventures of Master F. J. (1573), in Eriksen (ed.), Contexts of Pre-Novel Narrative: The European Tradition (Berlin: Mouton de Gruyter, 1994), pp. 185-228.

Evans, Robert C., Introduction to 'Verses made by a Maid under 14 (c. 165758)', in Helen Ostovich and Elizabeth Sauer (eds), Reading Early Modern Women: An Anthology of Texts in Manuscript and Print, 1550-1700 (New York: Routledge, 2004), p. 83.

Ezell, Margaret, 'The Myth of Judith Shakespeare: Creating the Canon of Women's Literature', New Literary History 21 (1990), pp. 579-92.

Ezell, Margaret, Writing Women's Literary History (Baltimore: Johns Hopkins University Press, 1996).

Felski, Rita, Beyond Feminist Aesthetics: Feminist Literature and Social Change (Cambridge, MA: Harvard University Press, 1989).

Fildes, Valerie, Breasts, Bottles and Babies: A History of Infant Feeding (Edinburgh: Edinburgh University Press, 1986).

Fildes, Valerie, Wet Nursing: A History from Antiquity to the Present (Oxford: Blackwell, 1988).

Findlay, Alison, Playing Spaces in Early Women's Drama (Cambridge: Cambridge University Press, 2006).

Fiorenza, Elisabeth Schüssler, But She Said: Feminist Practices of Biblical Interpretation (Boston: Beacon Press, 1993).

Fisher, Will, Materializing Gender in Early Modern English Literature and Culture (Cambridge: Cambridge University Press, 2006).

Fleming, Juliet, 'Dictionary English and the Female Tongue', in Richard Burt and John Michael Archer (eds), Enclosure Acts: Sexuality, Property, and Culture in Early Modern England (Ithaca: Cornell University Press, 1994), pp. 290-325.

Fletcher, Anthony, Gender, Sex, and Subordination, 1500-1800 (New Haven: Yale University Press, 1995).

Foucault, Michel, The Order of Things: An Archaeology of the Human Sciences (New York: Routledge, 2002).

Fudge, Erica, Brutal Reasoning: Animals, Rationality, and Humanity in Early Modern England (Ithaca: Cornell University Press, 2006).

Fudge, Erica, 'Calling Creatures by their True Names: Bacon, the New Science and the Beast in Man', in Fudge, Ruth Gilbert and Susan Wiseman (eds), At the Borders of the Human: Beasts, Bodies and Natural Philosophy in the Early Modern Period (New York: St. Martin's Press, 1999), pp. 91-109.

Garber, Marjorie, Coming of Age in Shakespeare (New York: Routledge, 1997).

Garber, Marjorie, 'The Logic of the Transvestite: The Roaring Girl', in David Scott Kastan and Peter Stallybrass (eds), Staging the Renaissance: Reinterpretations of Elizabethan and Jacobean Drama (New York: Routledge, 1991), pp. 221-34.

Greenblatt, Stephen, 'Fiction and Friction', in R. S. White (ed.), Twelfth Night (New York: St. Martin's Press, 1996), pp. 92-128. 
Greenblatt, Stephen, Shakespeare Negotiations (Berkeley: University of California Press, 1988).

Greenblatt, Stephen, Will in the World (New York: Norton, 2004).

Gregg, W. W., A Bibliography of English Printed Drama to the Restoration (London: Bibliographical Society, 1970).

Halberstam, Judith, Female Masculinity (Durham, NC: Duke University Press, 1998).

Hamilton, Sharon, Shakespeare's Daughters (Jefferson, NC: McFarland, 2003).

Hanawalt, Barbara, Growing up in Medieval London: The Experience of Childhood in History (Oxford: Oxford University Press, 1993).

Harding, D. W., 'Father and Daughter in Shakespeare's Last Plays', Times Literary Supplement (30 November 1979), pp. 59-61.

Hasselkorn, Anne M., 'Griselda, Renaissance Woman', in Hasselkorn and Betty Travitsky (eds), The Renaissance Englishwoman in Print: Counterbalancing the Canon (Amherst: University of Massachusetts Press, 1990), pp. 211-23.

Henderson, Katherine Usher, and Barbara F. McManus (eds), Half Humankind: Contexts and Texts of the Controversy about Women in England, 15401640 (Urbana: University of Illinois Press, 1985).

Heywood, Colin, A History of Childhood: Children and Childhood in the West from Medieval to Modern Times (Cambridge: Cambridge University Press, 2001).

Higginbotham, Jennifer, 'The Exile of Rose Hickman Throckmorton', Reformation 15 (2010), pp. 99-114.

Hildburgh, W. L., 'English Alabaster Carvings as Records of Medieval Religious Drama', Archaologia 93 (1949), pp. 51-102.

Howard, Jean E., 'An English Lass Amid the Moors: Gender, Race, Sexuality, and National Identity in Heywood's The Fair Maid of the West', in Margo Hendricks and Patricia Parker (eds), Women, 'Race,' and Writing in the Early Modern Period (New York: Routledge, 1994), pp. 101-17.

Howard, Jean E., 'Sex and Social Conflict: The Erotics of The Roaring Girl', in Susan Zimmerman (ed.), Erotic Politics: Desire on the Renaissance Stage (New York: Routledge, 1992), pp. 170-90.

Howard, Jean E., The Stage and Social Struggle in Early Modern England (London: Routledge, 1993).

Howard, Jean E., Theatre of a City: The Places of London Comedy, 1598-1642 (Philadelphia: University of Pennsylvania Press, 2007).

Howard, Jean E., and Phyllis Rackin, Engendering a Nation: A Feminist Reading of Shakespeare's English Histories (New York: Routledge, 1997).

Hughes, Felicity A., 'Gascoigne's Poses', Studies in English Literature, 1500190037 (1997), pp. 1-19.

Hunter, Jane, How Young Ladies Became Girls: The Victorian Origins of American Girlhood (New Haven: Yale University Press, 2002).

Hutchings, Mark, 'Mary Frith at the Fortune', Early Theatre 10 (2007), pp. 89-108.

Irigaray, Luce, 'The Power of Discourse and the Subordination of the Feminine', in Margaret Whitford (ed.), The Irigaray Reader (Oxford: Blackwell, 1991), pp. 118-27.

Jackson, Gabrielle Bernard, 'Topical Ideology: Witches, Amazons, and Shakespeare's Joan of Arc', English Literary Renaissance (1988), pp. 40-65. 
Jacobs, Deborah, 'Critical Imperialism and Renaissance Drama: The Case of The Roaring Girl', in Dale M. Bauer and Susan Jaret McKinstry (eds), Feminism, Bakbtin, and the Dialogic (Albany: SUNY Press, 1991), pp. 73-84.

Jakobson, Roman, 'The Concept of Mark', in Linda Waugh and Monique Monville-Burston (eds), On Language (Cambridge, MA: Harvard University Press, 1990), pp. 134-40.

Jameson, Anna, 'Characteristics of Women, Moral, Poetical, and Historical (London): Introduction, Portia, Helena, Hermione, Cleopatra', in Ann Thompson and Sasha Roberts (eds), Women Reading Shakespeare, 16601900 (Manchester: Manchester University Press, 1997), pp. 66-80.

Jankowski, Theodora, Pure Resistance: Queer Virginity in Early Modern English Drama (Philadelphia: University of Pennsylvania Press, 2000).

Jardine, Lisa, 'Twins and Travesties: Gender, Dependency and Sexual Availability in Twelfth Night', in Susan Zimmerman (ed.), Erotic Politics: Desire on the Renaissance Stage (New York: Routledge, 1992), pp. 27-38.

Jenstad, Janelle Day, 'Lying-in Like a Countess: The Lisle Letters, the Cecil Family, and A Chaste Maid in Cheapside', Journal of Medieval and Early Modern Studies 34 (2004), pp. 373-403.

Johnston, Mark, 'Prosthetic Absence in Ben Jonson's Epicoene, The Alchemist, and Bartholomew Fair', English Literary Renaissance 37:3 (2007), pp. 401-28.

Jones, Ann Rosalind, The Currency of Eros: Women's Love Lyric in Europe, 1540-1620 (Bloomington: Indiana University Press, 1990).

Jones, Ann Rosalind, 'Maidservants of London: Sisterhoods of Kinship and Labor', in Karen Robertson and Susan Frye (eds), Maids and Mistresses, Cousins and Queens: Women's Alliances in Early Modern England (Oxford: Oxford University Press, 1999), pp. 21-32.

Jones, Ann Rosalind, and Peter Stallybrass, Renaissance Clothing and the Materials of Memory (Cambridge: Cambridge University Press, 2000).

Jones, M. G., The Charity School Movement: A Study of Eighteenth Century Puritanism (Hamden: Archon, 1964).

Joseph, John E., Eloquence and Power: The Rise of Language Standards and Standard Languages (New York: Blackwell, 1987).

Jowitt, Claire, 'East versus West: Seraglio Queens, Politics, and Sexuality in Thomas Heywood's Fair Maid of the West, Parts I and II', in Galina I. Yermolenko (ed.), Roxolana in European Literature, History and Culture (Aldershot: Ashgate, 2010), pp. 57-70.

King, Margaret L., 'Concepts of Childhood: What We Know and Where We Might Go', Renaissance Quarterly 60 (2007), pp. 371-407.

Kleparski, Grzegorz, Theory and Practice of Historical Semantics: The Case of Middle English and Early Modern English Synonyms of Girl/Young Woman (Lublin: University Press of the Catholic University of Lublin, 1997).

Korda, Natasha, 'The Case of Moll Frith: Women's Work and the "All-Male Stage"', Early Modern Culture 4 (2004), <http://emc.eserver.org/1-4/korda. html> (accessed 21 June 2012).

Krantz, Susan E., 'The Sexual Identities of Moll Cutpurse in Dekker and Middleton's The Roaring Girl and in London', Renaissance and Reformation 19 (1995), pp. 5-20. 
'Lady Anne's Needlework: English Retreat and Scottish Tour 15th-30th June, 2012', <http://www.crewelwork.com/> (accessed 1 January 2012).

Lamb, Edel, Performing Childhood in the Early Modern Theatre: The Children's Playing Companies (1599-1613) (Basingstoke: Palgrave, 2009).

Lamb, Mary Ellen, 'The Agency of the Split Subject: Lady Anne Clifford and the Uses of Reading', English Literary Renaissance 22 (1992), pp. 347-68.

Lamb, Mary Ellen, 'Engendering the Narrative Act: Old Wives' Tales in The Winter's Tale, Macbeth, and The Tempest', Criticism 40 (1998), pp. 529-53.

Laqueur, Thomas, Making Sex: Body and Gender from the Greeks to Freud (Cambridge, MA: Harvard University Press, 1990).

Lawhorn, Mark, 'Children in Shakespeare's Plays: An Annotated Checklist', in Kate Chedgzoy, Susanne Greenhalgh and Robert Shaughnessy (eds), Shakespeare and Childhood (Cambridge: Cambridge University Press, 2007), pp. 233-49.

Levine, Laura, Men in Women's Clothing: Anti-theatricality and Effeminization, 1579-1642 (Cambridge: Cambridge University Press, 1994).

Levy, Santina, 'Embroidery, Renaissance to Rococo', in The Victoria \& Albert Museum's Textile Collection: Embroidery in Britain from 1200-1750 (London: Victoria \& Albert Museum, 1992), pp. 15-20.

Lewalski, Barbara Kiefer, 'Rewriting Patriarchy and Patronage: Margaret Clifford, Anne Clifford, and Aemilia Lanyer', Yearbook of English Studies 21 (1991), pp. 87-106.

Lewalski, Barbara Kiefer, Writing Women in Jacobean England (Cambridge: Cambridge University Press, 1993).

Low, Jennifer, “Women are Wordes, Men are Deedes”: Female Duelists in the Drama', in Linda Woodbridge and Sharon Beehler (eds), Women, Violence, and English Renaissance Literature: Essays Honoring Paul Jorgensen (Tempe: Arizona Center for Medieval and Renaissance Studies, 2003), pp. 271-302.

McLuskie, Kathleen, Dekker and Heywood: Professional Dramatists (New York: St. Martin's Press, 1994).

McManus, Clare, 'The Roaring Girl and the London Underworld', in Garret Sullivan, Patrick Cheney and Andrew Hadfield (eds), Early Modern English Drama: A Critical Companion (Oxford: Oxford University Press, 2006), pp. 213-24.

McManus, Clare, Women and Culture at the Courts of the Stuart Queens (New York: Palgrave, 2003).

McMullen, Nancy, 'Education of English Gentlewomen', History of Education 6 (1977), pp. 87-101.

Marshall, Gail, Shakespeare and Victorian Women (Cambridge: Cambridge University Press, 2009).

Mechling, Jay, 'Advice to Historians on Advice to Mothers', Journal of Social History 9 (1975), pp. 44-63.

Mendelson, Sara, and Patricia Crawford, Women in Early Modern England, 1550-1720 (Oxford: Oxford University Press, 1998).

Mentz, Steve, 'Escaping Italy: From Novella to Romance in Gascoigne and Lyly', Studies in Philology 2 (2004), pp. 153-71.

Mikalachki, Jodi, 'Gender, Cant, and Cross-talking in The Roaring Girl', Renaissance Drama 25 (1994), pp. 119-43. 
Mitchell, Sally, The New Girl: Girls' Culture in England 1880-1915 (New York: Columbia University Press, 1995).

Mohanty, Chandra, Feminism Without Borders: Decolonizing Theory: Practicing Solidarity (Durham, NC: Duke University Press, 2003).

Moi, Toril, What Is a Woman? And Other Essays (Oxford: Oxford University Press, 1999).

Mulholland, Paul, 'The Date of The Roaring Girl', Review of English Studies 28 (1977), pp. 18-31.

Munro, Lucy, Children of the Queen's Revels (Cambridge: Cambridge University Press, 2005).

Nares, Robert, A Glossary, or Collection of Words, Phrases, Names and Allusions to Customs, Proverbs, etc., Which Have Been Thought to Require Illustration, in the Works of English Authors, Particularly Shakespeare and His Contemporaries (London: Reeves and Turner, 1888).

Narveson, Kate, 'Authority, Scripture, and Typography in Lady Grace Mildmay's Manuscript Meditations', in Micheline White (ed.), English Women, Religion, and Textual Production, 1500-1625 (Aldershot: Ashgate, 2011), pp. 167-84.

Newman, Karen, Fashioning Femininity and English Renaissance Drama (Chicago: University of Chicago Press, 1991).

O'Connor, Marion, 'Rachel Fane's May Masque at Apethorpe, 1627', English Literary Renaissance (2006), pp. 90-113.

Oosterwijk, Sophie, 'Of Mops and Muppets: The Ambiguous Use of the Word "Mop" in the Towneley Shepherds Plays', Notes and Queries 44 (1997), pp. 169-71.

Orgel, Stephen, Impersonations: The Performance of Gender in Shakespeare's England (Cambridge: Cambridge University Press, 1996).

Orgel, Stephen, 'Nobody's Perfect, Or Why Did the English Stage Take Boys for Women?', South Atlantic Quarterly 88 (1989), pp. 7-29.

Orgel, Stephen, 'The Subtexts of The Roaring Girl', in Susan Zimmerman (ed.), Erotic Politics: Desire on the Renaissance Stage (New York: Routledge, 1992), pp. 12-26.

Orme, Nicholas, Medieval Children (New Haven: Yale University Press, 2001).

Parker, Rozsika, The Subversive Stitch: Embroidery and the Making of the Feminine (London: Women's Press, 1984).

Payne, Elizabeth Rogers (ed.), Sapientia Solomonis, Acted Before the Queen by the Boys of Westminster School (New Haven: Yale University Press, 1938).

Pendleton, Thomas A., 'How Many Children Had William Shakespeare?', Shakespeare Newsletter 58:1 (2008), p. 25.

Pfister, Manfred, “"Man's Distinctive Mark”: Paradoxical Distinctions Between Man and His Bestial Other in Early Modern Texts', in Elmar Lehmann and Bernd Lenz, Telling Stories: Studies in Honour of Ulrich Broich on the Occasion of His 60th Birthday (Amsterdam: Gruner, 1992).

Phillips, Kim M., Medieval Maidens: Young Women and Gender in England, 1270-1540 (Manchester: Manchester University Press, 2003).

Phillipy, Patricia, 'The Maid's Lawful Liberty: Service, the Household, and "Mother B" in Isabella Whitney's A Sweet Nosegay', Modern Philology (1998), pp. 439-62.

Pigman III, G. W., 'Editing Revised Texts: Gascoigne's A Hudredth Sundrie 
Flowres and The Posies', in W. Speed Hill (ed.), New Ways of Looking at Old Texts, II: Papers of the Renaissance English Text Society, 1992-1996 (Tempe: Medieval and Renaissance Texts and Studies, 1998), pp. 1-9.

Pollock, Linda, Forgotten Children: Parent-Child Relationships 1500-1900 (Cambridge: Cambridge University Press, 1983).

Pollock, Linda, A Lasting Relationship: Parents and Children Over Three Centuries (Ann Arbor: University of Michigan, 1987).

Pollock, Linda, With Faith and Physic: The Life of a Tudor Gentlewoman: Lady Grace Mildmay, 1552-1620 (London: Collins \& Brown, 1993).

Potter, Ursula, 'Tales of Griselda and Henry VIII', Early Theatre 5 (2002), pp. 11-28.

Proudfoot, Richard, 'Verbal Reminiscences and the Two Part Structure of The Winter's Tale', Shakespeare Survey 29 (1976), pp. 67-78.

Purkiss, Diane, 'Marvell, Boys, Girls and Men: Should We Worry?', in Naomi J. Miller and Naomi Yavneh (eds), Gender and Early Modern Constructions of Childhood (Aldershot: Ashgate, 2011), pp. 181-92.

Rackin, Phyllis, 'Androgyny, Mimesis, and the Marriage of the Boy Heroine on the English Renaissance Stage', PMLA 102 (1987), pp. 29-41.

Rich, Adrienne, Time's Power: Poems 1985-1988 (New York: Norton, 1989).

Roberts, Warren E., 'Ballad Themes in The Fair Maid of the West', Journal of American Folklore 68 (1955), pp. 19-23.

Röll, Michaela, “"Three”-floating Sexuality: Viola's Identity in Shakespeare's Twelfth Night', The Upstart Crow (1998), pp. 39-55.

Roper, Lyndal, Oedipus and the Devil: Witchcraft, Sexuality, and Religion in Early Modern Europe (New York: Routledge, 1994).

Rose, Mary Beth, 'Women in Men's Clothing: Apparel and Social Stability in The Roaring Girl', English Literary Renaissance 14 (1984), pp. 367-91.

Rowse, A. L., Simon Forman: Sex and Society in Shakespeare's Age (London: Weidenfeld \& Nicolson, 1974).

Salzman, Paul (ed.), An Anthology of Elizabethan Prose Fiction (Oxford: Oxford University Press, 1987).

Salzman, Paul, Reading Early Modern Women's Writing (Oxford: Oxford University Press, 2006).

Schulz, Muriel R., 'The Semantic Derogation of Woman', in Barrie Thorne and Nancy Henley (eds), Language and Sex: Difference and Dominance (Rowley, MA: Newbury House, 1975), pp. 64-75.

Scolnicov, Hanna, 'Ages of Man, Ages of Woman', Cahiers Elisabéthains 56 (2000), pp. 61-78.

Seaton, Ethel, Literary Relations of England and Scandinavia in the Seventeenth Century (Oxford: Clarendon, 1935).

Sebek, Barbara, "Strange Outlandish Wealth": Transglobal Commerce in The Merchant's Mappe of Commerce and The Fair Maid of the West, Parts $I$ and II', in John Gillies and Virginia Mason Vaughn (eds), Playing the Globe: Genre and Geography in English Renaissance Drama (Madison, NJ: Fairleigh Dickinson University Press, 1998), pp. 176-202.

Seelig, Sharon Cadman, Autobiography and Gender in Early Modern Literature: Reading Women's Lives, 1600-1800 (Cambridge: Cambridge University Press, 2006). 
Serrano, Julia, Whipping Girl: A Transsexual Woman on Sexism and the Scapegoating of Femininity (Emeryville, CA: Seal Press, 2007).

Shannon, Laurie, 'Nature's Bias: Renaissance Homonormativity and Elizabethan Comic Likeness', Modern Philology 98 (2000), pp. 183-210.

Shapiro, Michael, 'The Westminster Scholars' Sapientia Solomonis as Royal Gift Offering', in Paul Menzer (ed.), Inside Shakespeare: Essays on the Blackfriars Stage (Susquehanna: Susquehanna University Press, 2006), pp. 118-31.

Skeat, Walter W., An Etymological Dictionary of the English Language (Oxford: Oxford University Press, [1879] 1935).

Smith, Sidonie, and Julia Watson, 'Introduction', in Women, Autobiography, Theory: A Reader (Madison: University of Wisconsin Press, 1998), pp. 21-7.

Snell, K. D. M., 'The Apprenticeship of Women', in Annals of the Labouring Poor: Social Change and Agrarian England, 1660-1900 (Cambridge: Cambridge University Press, 1985), pp. 270-318.

Snyder, Susan, 'Mamillius and Gender Polarization in The Winter's Tale', Shakespeare Quarterly 50 (1999), pp. 1-8.

Spence, Richard T., Lady Anne Clifford (Stroud: Sutton, 1997).

Stage, Kelly J., 'The Roaring Girl's London Spaces', Studies in English Literature 49 (2009), pp. 417-36.

Stallybrass, Peter, 'Transvestism and the Body Beneath: Speculating on the Boy Actor', in Susan Zimmerman (ed.), Erotic Politics: Desire on the Renaissance Stage (New York: Routledge, 1992), pp. 50-64.

Staub, Susan, 'The Lady Frances Did Watch: Gascoigne's Voyeuristic Narrative', in Constance Relihan (ed.), Framing Elizabethan Fictions: Contemporary Approaches to Early Modern Narrative (Kent: Kent State University Press, 1996), pp. 41-54.

Stuart, Roxana, 'Dueling en Travestie: Cross-Dressed Swordfighters in Three Jacobean Comedies', Theatre Studies 38 (1993), pp. 29-43.

Suzuki, Mihoko, 'Anne Clifford and the Gendering of History', Clio 30 (2001), pp. 195-230.

Taylor, Miles, “Teach Me This Pedlar's French”: The Allure of Cant in The Roaring Girl and Dekker's Rogue Pamphlets', Renaissance and Reformation 29 (2005), pp. 107-24.

Thomas, Helen, 'Jacob and Esau: "Rigidly Calvinistic"?', Studies in English Literature, 1500-1900 9 (1969), pp. 199-213.

Thorne, Barrie, and Nancy Henley, 'Difference and Dominance: An Overview of Language, Gender, and Society', in Thorne and Henley (eds), Language and Sex: Difference and Dominance (Rowley, MA: Newbury House, 1975), pp. 5-42.

Tomlinson, Alicia, 'Moll's Law: The Roaring Girl, Mary Frith, and Corrupt Justice from the Streets to the Star Chamber', Ben Jonson Journal 15 (2008), pp. 205-31.

Tomlinson, Sophie, Women on Stage in Stuart Drama (Cambridge: Cambridge University Press, 2004).

Traister, Barbara Howard, The Notorious Astrological Physician of London: Works and Days of Simon Forman (Chicago: University of Chicago Press, 2001).

Traub, Valerie, The Renaissance of Lesbianism in Early Modern England (Cambridge: Cambridge University Press, 2002). 
Travitsky, Betty (ed.), The Paradise of Women: Writings by Englishwomen of the Renaissance (Westport, CT: Greenwood Press, 1981).

Travitsky, Betty, 'The "Wyll and Testament" of Isabella Whitney', English Literary Renaissance 10 (1980), pp. 76-96.

Tucker, Edward Frederick John (ed.), Ferdinando Parkhurst's Ignoramus, the Academical-Lawyer: A Critical Edition (New York: Garland, 1987).

Tylus, Jane, 'Translating Griselda: Holy Women and the Vernacular in Renaissance Italy', paper presented at the Center for Medieval and Renaissance Studies, The Ohio State University, Columbus, 5 November 2010.

Varty, Anne, 'The Rise and Fall of the Victorian Stage Baby', New Theatre Quarterly 21 (2005), pp. 218-19.

Vasvári, Louise O., 'The Story of Griselda as Silenced Incest Narrative', Corónica: A Journal of Medieval Spanish Language, Literature, and Cultural Studies 35 (2007), pp. 139-56.

Vickers, Brian, 'The Emergence of Character Criticism', Shakespeare Survey 34 (1981), pp. 11-21.

Wallace, David, 'Holy Amazon: Mary Ward of Yorkshire, 1585-1645', Strong Women: Life, Text, and Territory 1347-1645 (Oxford: Oxford University Press, 2011).

Wallace, David, 'Periodizing Women: Mary Ward (1585-1645)', Journal of Medieval and Early Modern Studies 36 (2006), pp. 397-453.

Wheeler, Richard, 'Deaths in the Family: The Loss of a Son and the Rise of Shakespearean Comedy', Shakespeare Quarterly 51 (2000), pp. 127-53.

White, Paul Whitfield, 'Predestinarian Theology in the Mid-Tudor Play Jacob and Esau', Renaissance and Reformation 24 (1988), pp. 291-302.

Wickham, Glynne, 'The Dramatic Structure of Rehabilitation in Shakespeare's Henry VIII', Proceedings of the British Academy 70 (1984), pp. 149-66.

Wickham, Glynne, 'Romance and Emblem: A Study in the Dramatizing Structure of The Winter's Tale', in David Galloway (ed.), Elizabethan Theatre III (Toronto: Macmillan, 1973), pp. 82-99.

Wickham, Glynne, 'The Winter's Tale: A Comedy with Deaths', in Shakespeare's Dramatic Heritage (London: Routledge, 1969), pp. 249-56.

Williams, Deane, 'Papa Don't Preach: The Power of Prolixity in Pericles', University of Toronto Quarterly: A Canadian Journal of the Humanities 71 (2002), pp. 595-622.

Williamson, George C., Lady Anne Clifford, Countess of Dorset, Pembroke, and Montgomery, 1590-1676: Her Life, Letters, and Work (Kendal: Titus Wilson and Son, 1922).

Wilson, Adrian, The Making of Man-Midwifery: Childbirth in England, 16601770 (Cambridge, MA: Harvard University Press, 1995).

Witmore, Michael, Pretty Creatures: Children and Fiction in the English Renaissance (Ithaca: Cornell University Press, 2007).

Wittig, Monique, 'One Is Not Born a Woman', in Henry Abelove, Michèle Aina Barale and David M. Halperin (eds), The Lesbian and Gay Studies Reader (New York: Routledge, 1993), pp. 103-9.

Woodbridge, Linda, Women and the English Renaissance: Literature and the Nature of Womankind, 1540 to 1620 (Urbana: University of Illinois Press, 1984). 
Woolf, Virginia, A Room of One's Own (San Diego: Harcourt Brace, 1922), pp. 46-8.

Yates, Frances, Majesty and Magic in Shakespeare's Last Plays (Boulder, CO: Shambhala, 1978).

Yeandle, Laetitia, 'A School for Girls in Windsor', Medieval and Renaissance Drama 17 (2005), pp. 272-80.

Zeigler, Georgiana, 'Devising a Queen: Elizabeth Stuart's Representation in the Emblematic Tradition', Emblematica: An Interdisciplinary Study of Emblem Studies 14 (2005), pp. 155-79. 


\section{Index}

Adelman, Janet, 109

Adventures of Master F. J.

(Gascoigne), 9, 63, 65, 74-9, 86-7, 88

Alphonsus, Emperor of Germany, 110, 136

Althusser, Louis, 72

Anderson, M. D., 138n6

Anything for a Quiet Life (Middleton and Webster), 145, 162

apprenticeships for girls, 12, 29-30, 58n17, 96, 164

Ariès, Philippe, 10-11, 13, 145

Ascham, Roger, 70-1

Bacon, Francis, 13

baptism and christening, 66-7, 121-7, 142n60, 192

Bartolovich, Crystal, 97

Baston, Jane, 91

Beaumont, Francis, 172

Becon, Thomas, 71-5

Belsey, Catherine, 144

Ben-Amos, Ilana Krausman, 29-30, 66,164

Bergeron, David, 107

Bevington, David, 146

Bicks Caroline, 166-7

Birck, Sixtus, 135, 137n5

Blind Beggar of Alexandria, 111, 136

Book of Common Prayer, 124-5

Bornstein, Kate, 92

boys

baptism of, $124-5$ boy actresses, 3-4, 15n $5,79-80$, $81,108-9,137 \mathrm{n} 5,144-7$, $160-1,162,165,169$

coming of age, 13, 18n $32,36-7$, 120

differentiated from men, 2-4, 9, $10,18 \mathrm{n} 32$

education, $10,35,67,68,70$, 128-9, 132, 149-50

gender preferences for, 121, 128-9, 132,135

gendering of, $2-4,9,10,18 \mathrm{n} 32$, $32-4,41,67$

lexical history, 30-1, 32-3, 40 paired with girls, 41, 112-13, 161-2, 163

place in gender hierarchy, 2-4, 9, $10,12,36-7,158-9$

roaring boys, $88-9$

see also childhood; infants;

tripartite model

Brackley, Elizabeth, 172

Brome, Richard, 56, 147, 169, 171

Brome, Stephen, 56

Brown, Pamela Allen, 62, 158

Buck, Anne, 12, 140n43

Bushnell, Rebecca, 67, 70

Butler, Judith, 64, 86, 93, 109, 198

The Byrth of Mankynde, 39-40

Callahan, Dympna, 109

Carey, Lettice, 67

Cavell, Stanley, 21

Cavendish, Jane, 172 
Cavendish, Margaret, 95

The Chances (Fletcher), 106, 132-3, 136

Chapman, George, 136

Chaste Maid in Cheapside

(Middleton), 9, 105, 124, 127, $131-5,136$

Chaucer, 34, 158

Chedgzoy, Kate, 173-4, 181

Chettle, Henry, 136, 158, 160-1

childhood

fictional representations of, 104-7, 110-12, 114-23, 125-35, 144-74

gender differences in, 10-14, 33-7, $112-13,148$

historiography, 10-14, 66-7, $113-14,123,145,147$

relationship to adulthood, 3 , $10-13,22,25,31-3,35,37$, 63-4, 71, 74, 81-2, 96-8, 104-5, 108-9, 112, 115-16, $120,134-5,146-9,151,154-5$, $158,182-3,191-4$

Clifford, Anne childhood letter, 179-80 diary, 14, 183, 188-96 relationship with daughter

Margaret, 191-5

Clifford, Margaret (Anne Clifford's daughter), 191-5

Clifford, Margaret (Anne Clifford's mother), 182-4

The Cobbler's Prophesy, 106, 125-7, 130, 131, 136

Comenius, John Amos, 35-6, 112, 115, 124; see also Orbis Sensualium Pictus

Comodye of Pacient and Meeke Grissill (Phillips), 135, 148, 158-60

Concealed Fancies (Brackley and Cavendish), 172

conduct manuals, 65-6, 67-74, 97, $127,149,154,158-9,187$

Consistory Court of London Correction Book, 93

Cooper, Thomas, 20-1; see also dictionaries
The Country Girl, 49, 54-5

Cowden Clarke, Mary, 5-7, 11

Crawford, Patricia, 12, 64, 142 n56

Crupi, Charles, 43-4

Culpeper, Nicholas, 41

Cunningham, Hugh, 10-11, 13, 66, 123,147

Curzan, Anne, 34

Damsels, 20, 21, 22, 23, 30, 37, $38-9,48,90,112,126,165$

Dekker, Thomas The Bloody Banquet, 136

The Pleasant Comodie of Patient Grissel, 136, 158, 160-1

The Roaring Girl, 9, 54, 63, 74, 79, 87-95

Wonderfull Yeare, 143n68

dictionaries

Bibliotheca Eliotae, 20

Dictionary of the English Language, 30-1

An English Expositor, 58n14

Lesclarcissement de la langue francoyse, 33-5

A New English Dictionary Shewing the Etymological Derivation of the English Tongue, 30

Thesaurus Linguae Romanae \& Britannicae, $57 \mathrm{n} 1$

Vocabulario Italiano e Inglese, 29

A Worlde of Wordes, or Most Copious, Dictionarie in Italian and English, 29

see also Cooper, Thomas; Elyot, Thomas; Florio, John; Johnson, Samuel; Torriano, Giovanni

Dusinberre, Juliet, 108

education of female children, 10-11, 66-75, 105, 115-16, 148-50, $155,159,163-4,167,169-72$, $180,185-8,196-7$

Elizabeth I (Henry VIII), 110, 121-3, 145

Elyot, Thomas, 20, 68; see also dictionaries 
Erickson, Amy Louise, 8, 129

Eriksen, Roy, 100n36

Evans, Robert C., 180

Fair Quarrel (Middleton and

Rowley), 9, 105, 127-8, 129-31, 136

Fane, Rachel, 172-4, 180-1

Findlay, Alison, 172

Fiorenza, Elisabeth Schüssler, 152

Fisher, Will, 9, 12-13

Fleming, Juliet, 28

Fletcher, Anthony, 64-5

Fletcher, John

collaborating with Shakespeare, 121,135

female child characters, 164-6

infant characters, 106, 132, 135, 136

read by Rachel Fane, 172

WORKS

The Chances, 106, 121-3, 132-3, 136

Fair Maid of the Inn, 49

Henry VIII, 121-3, 135, 136

The Humorous Lieutenant, 164-6

The Knight of Malta, 136

see also individual characters

Florio, John, 29; see also dictionaries

Foucault, Michel, 28

Frith, Mary (historical person), 87, 93-4

Frith, Moll (Roaring Girl), 43, 55, $63,79,87-94,96$

Fudge, Erica, 104-5

Gascoigne, George, 9, 63, 74-9, 81, 82, 86-7, 95; see also Adventures of Master F. J.

Girlhood of Shakespeare's Heroines, 5-7 girls

as adolescents, 29-30, 41-2, 159 as infants, 4-5, 9-10, 25, 32, 36-7, 39-41, 66-8, 104-43, 144, 145, $154,159,192$

lexical history, 20-42 as performers, $166-9,172-4$

in poetry, 25-6, 39, 96-7, 180-1

servants, 12, 24-5, 27, 29-30, 31, $33,37,38,44,47,96-7,128-9$, $151-7,163-4,165$

as writers, 172-4, 179-82

Gosson, Stephen, 166

Greenblatt, Stephen, 108-9

Gregg, W. W., 50

Griselda legend, 110, 135-6, 145, $148,158-61$

Guillemeau, Jacques, 40, 113

Haec Vir, or, The Womanish Man, 73

Halberstam, Judith, 79

Harington, John, 39

Haughton, William, 136, 158, 160, 161

Henley, Nancy, 32

Herrick, Robert, 22-3

Heywood, Thomas

female child characters, 165

infant characters, 106, 111, 136

WORKS

Fair Maid of the Exchange, 49

Fair Maid of the West, 8-9, 42-54

If You Know Not Me, You Know

Nobody, Part Two, 165

A Pleasant Comedy, called a Mayden-head Well Lost, 111, 137

Hic Mulier, or, the Man-Woman, 73

Hildburgh, W. L., 138n6

Howard, Jean E., 44-5, 48, 52, 80, 91, 166

Hughes, Felicity A., 101n43

Ignoramus (Ruggle), 146, 163-4

infants

gender ambiguity, 30-2, 33, 39,

112-14

gender differences, 41, 108-10, 124-5

as a life stage, $25,37,67-8$

on stage, 4-5, 9-10, 104-8,

110-12, 114-23, 125-7,

129-37, 138n6, 144-5, 154, 159

see also midwifery manuals 
Irigaray, Luce, 1-2, 111

Isham, Elizabeth, 66-7

Jacob and Esau, 14, 145, 148, 151-7, 158,163

Jacobs, Deborah, 91

Jakobson, Roman, 32

Jankowski, Theodora, 81, 85

jest books, 62-3, 93, 94

Joan la Pucelle (1 Henry VI), 63, 79-86, 88

Johnson, Samuel, 30-1, 58n22

Johnston, Mark, 109

Jonas, Richard, 39-40

Jones, Ann Rosalind, 94, 171

Joseph, John E., 28

Jowitt, Claire, 43-4, 51, 52, 53-4

Juliet (Romeo and Juliet), 5, 26-7, 146,154

King, Margaret L., 17n28, 146

Kleparski, Grzegorz, 22, 34, $143 n 68$

Lamb, Mary Ellen, 120, 188

Langland, William (Piers Plowman), 34

Laqueur, Thomas, 108, 109; see also one-sex model

A Larum for London, 145, 161-2

lasses, 22-3, 29, 31, 55-6

The Lawes Resolutions of Women's Rights, 12

life writing, 66-7, 179-98

Lumley, Jane, 95, 172

McLuskie, Kathleen, 52

McManus, Clare, 167, 169

Maids, 1-2, 7-8, 12, 20, 22, 25-31, 33, 35, 37-8, 39, 41-2, 43, 44, 45-9, 51-4, 62, 63, 68-70, 72, $81-5,90,115-16,149,163-5$, 171, 180-2

Marina (Pericles), 5, 106-7, 110, 112, 114-16, 118, 123, 145

Marlowe, Christopher, 83, 163

Mendelson, Sara, 12, 64, 142n56

Mentz, Steve, 76
Middleton, Thomas

Anything for a Quiet Life, 162

A Chaste Maid in Cheapside, 9, 105, 124, 127, 131-5, 136

A Fair Quarrel, 9, 105, 127-8, 129-31, 136

The Roaring Girl, 9, 38, 54, 63, 79, 87-95

midwifery manuals, 12, 39-42, 113

Mildmay, Grace, 14, 66, 67, 172, 183, 184-8, 189, 190, 196, 197

The Misfortunes of Arthur, 110, 136

Moi, Toril, 3-4

Mulcaster, Richard, 69-71; see also education of female children

Munro, Lucy, 147

Newman, Karen, 65, 73

Nice Wanton, 14, 145, 148-51, 158, 163

Northern Lass (Brome), 55-6

nurses, 27, 67, 114, 120, 126, 129, 130, 134, 146, 154, 158, 163

O’Connor, Marion, 172

one-sex model, 15n5, 108-9

Oosterwijk , Sophie, 138n

Orbis Sensualium Pictus, 35-7, 112, 115,124

Orgel, Stephen, 2-3, 88, 108

Palsgrave, John, 30, 34-5

Pandosto, 108, 118

Paré, Ambroise, 40-1

Parker, Rozsika, 171

Perdita (Winter's Tale), 5, 33, 110, 112, 116-21, 123, 145, 160

Phillip, John, 135, 148, 158-60

Phillipy, Patricia, 96

Piers Plowman, 34

The Pleasant Comodie of Patient

Grissel (Chettle, Haughton and

Dekker), 136, 158, 160-1

Pollock, Linda, 184, 188

Positions Concerning the Training

Up of Children (Mulcaster),

69-71 
Pulter, Hester, 25-6

Purkiss, Diane, 120

The Queen and Concubine (Brome), $145,147,169-72$

Rackin, Phyllis, 80, 108

Raynald, Thomas, 40; see also The Byrth of Mankynd

The Roaring Girl (Middleton and Dekker), 9, 38, 54, 63, 79, 87-95; see also Frith, Mary

Roberts, Warren E., 60n

Rösslin, Eucharius, 39-40; see also The Byrthe of Mankynde; midwifery manuals

Rowley, William

A Fair Quarrel, 9, 105, 127-31, 136

The Thracian Wonder, 111, 136

Ruggle, George, Ignoramus, 146, $163-4,165$

Sapientia Solomonis, 135, 137n5

Schulz, Murial, 38

Scolnicov, Hannah, 35

Sebek, Barbara, 43-4, 50

The Second Shepherds' Play, 143n69

Shakespeare, William infants on stage, 105-8, 110, 112, 114-23

lack of female child characters, 4-5, 144-6

use of term 'girl', 5, 23-5, 26-7

WORKS

Antony and Cleopatra, 24-5, 40, 41, 144

As You Like It, 3, 5, 23-4, 43, 46, 109, 144

Hamlet, 5

1 Henry VI, 63, 79-86, 95

Henry VIII, 9, 105, 107, 108, 121-3, 135, 136

Merchant of Venice, 5, 163

Merry Wives of Windsor, 145, 163, 168

Midsummer Night's Dream, 130

Pericles, 9, 105, 106, 107, 111-12, 114-16, 118, 120, 121, 127, 136
Richard III, 4, 115, 145, 161

Romeo and Juliet, 5, 26-7, 37, 146,154

Tempest, 5

Titus Andronicus, 5, 23, 106, 136

Twelfth Night, 33, 46, 108

The Winter's Tale 9, 33, 41, 105, $107,110,111,112,115,116-$ $121,136,160$

see also individual characters

Sharp, Jane, 12, 41-2

Snell, K. D. M., 164

Snyder, Susan, 119

Speght, Rachel, 172

Stallybrass, Peter, 108, 171

Staub, Susan, 76, 79

Thorne, Barrie, 32

Thracian Wonder (Webster and Rowley), 111, 136

Throckmorton, Rose Hickman, 14, 183, 196-7

Tom a Lincoln, 111, 136

Tomlinson, Alicia, 91, 93

Tomlinson, Sophie, 172

Torriano, Giovanni, 29

The Tragedie of Nero, 110, 136

Traister, Barbara Howard, 117-18

Traub, Valerie, 24

Travitsky, Betty, 96

tripartite model, 3-4, 9, 113-14, 182

'Verses made by a Maid under 14', 180-1

Vives, Juan Luis, 68-9, 71, 94

Wallace, David, 166-7

A Warning for Fair Women, 145, 161

The Weakest Goeth to the Wall, 111-12, 136

Webster, John

Anything for a Quiet Life, 162

A Cure for a Cuckold, 136

Duchess of Malfi, 136

Wenches, 1-2, 7, 9, 20, 22-3, 29, $37-8,40,42,45,46,53,70,80$, 90, 91, 131, 133-4, 151, 154, 156,165 
White, Robert, 167-9

Whitney, Isabella, 95-7

Williams, Deane, 116

Wilson, Robert, 106, 125-7, 130, 131, 136

Witmore, Michael, 181

Wittig, Monique, 1, 4, 64

women writers, 25-6, 66-7, 95-7, 172-4, 179-98; see also
Brackley, Elizabeth; Cavendish, Jane; Clifford, Anne; Clifford, Margaret; Fane, Rachel; Isham, Elizabeth; Lumley, Jane;

Mildmay, Grace; Throckmorton, Rose Hickman; Whitney, Isabella

Yeandle, Laetitia, 169 




